DEPARTMENT OF THE INTERIOR

Francind K. LANE, Secretary

UNTTED STATES GeOLOGICAL SURVAX Georon Orrs Surnt, Director

\title{
BuLtimin 688
}

\section{THE OIL FIELDS OF ALLEN COUNTY KENTUCKY}

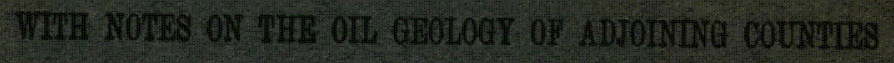

BX:

TUGENE WESTEY SHAW

AND

KURTLEY F. MATHER

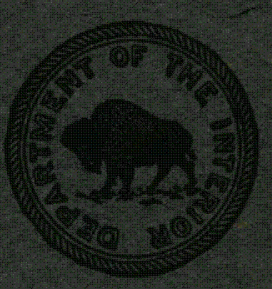

WASHINGTON

GOVERAMENT PRIXTING ONTIOR

1919 
DEPARTMENT OF THE INTERIOR

Franklin K. LANE, Secretary

\section{United States Geological Survey}

George OtLS SMith, Director

\section{Bulletin 688}

\section{THE OIL FIELDS OF ALLEN COUNTY KENTUCKY}

WITH NOTES ON THE OIL GEOLOGY OF ADJOINING COUNTIES

BY

EUGENE WESLEY SHAW

AND

KIRTLEY F. MATHER

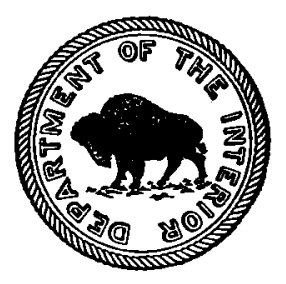

WASHIN GTON

GOVERNMENT PRINTING OFFICE

1919 



\section{CONTENTS.}

Introduction $. \ldots \ldots \ldots \ldots \ldots \ldots \ldots \ldots \ldots \ldots \ldots \ldots \ldots \ldots \ldots \ldots \ldots \ldots \ldots,{ }^{\text {Page. }}$

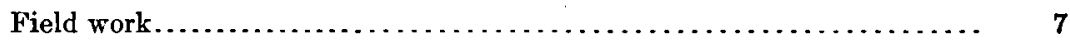

Annotated bibliography....................................... 8

Acknowledgments........................................... 15

Geography of the region..................................... 15

Location and area........................................... 15

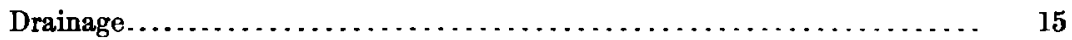

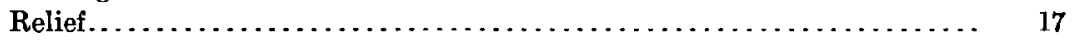

Roads and towns in and near Allen County................... 17

History of the oil industry of the region.......................... 18

Distribution and extent of the oil fields............................ 22

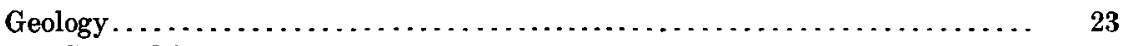

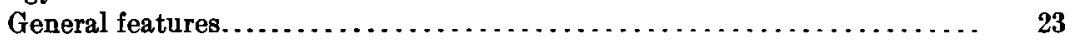

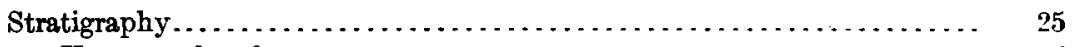

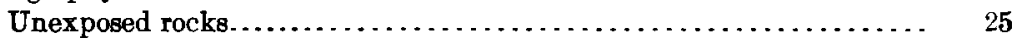

Generalized sections and well records.................. 25

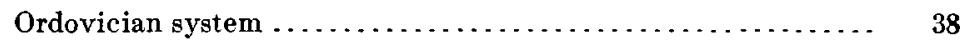

Exposed rocks. .................................. 40

Rocks lying near the surface in the producing area........... 40

Silurian system .................................... 40

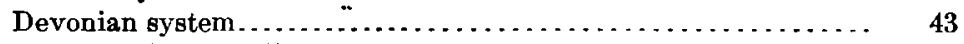

"Corniferous" limestone.......................... 47

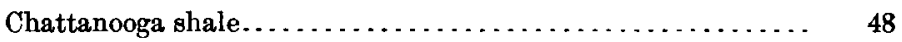

Carboniferous system................................ 51

Mississippian series........................... 51

Rocks between the black ('hattanooga shale and the St. Louis limestone......................... 51

General character......................... 51

New Providence shale....................... 58

Fort Payne chert.................... 60

Warsaw limestone......................... 61

Spergen (?) limestone........................ 61

St. Louis limestone ........................... $\quad 61$

Ste. Genevieve limestone....................... $\quad \mathbf{6 2}$

Chester group (in whole or in part) ............... $\quad 64$

Pennsylvanian series........................... 64

Quaternary system................................ 64 
Geology-Continued. Page.

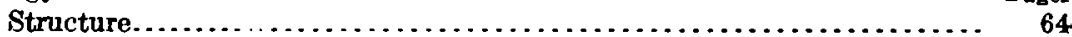

General relations............................................ 64

Accuracy of structure contours. . . . . . . . .

Principal structural features................................. 67

Anticlines........................................ 67

North Petroleum anticline............................ $\quad 67$

Rodemer anticline............................... $\quad 67$

Petroleum anticline.............................. 68

Rough Creek anticline............................ 68

Trammel anticline $. . . \ldots \ldots \ldots \ldots \ldots \ldots \ldots \ldots \ldots \ldots \ldots \ldots . . \ldots 6$

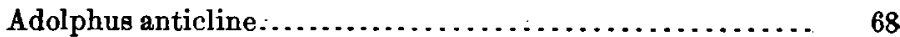

Other anticlines.................................. $\quad 69$

Synclines......................................... $\quad 69$

Hinton syncline................................ 69

Turlock basin .................................... $\quad 69$

Relation of oil reservoirs to structure........................ 69

Convergence of beds....................................... 71

Joints............................................... 71

Character and position of the "pay sands"...................... 71

"Sands" in the "Corniferous" limestone...................... 72

"Sands" in the Silurian limestone........................... 74

Beaver Creek (?) "sand" ................................. 74

Character of the oil............................................ $\quad 75$

Oil below the black shale.................................... 75

"Amber oil"'............................................. 77

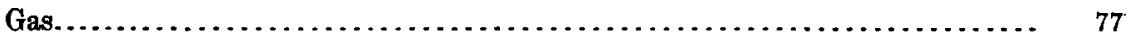

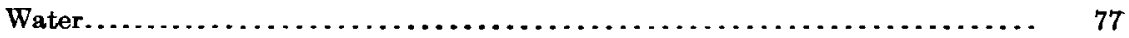

Capacity and life of wells and amount of oil still in the pools............ 82

Basis for estimating productivity.......................... 82

Percentage of oil recoverable................................. 83

Capacity of wells.......................................... 84

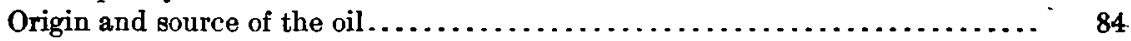

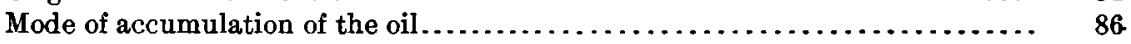

Surface indications of oil and gas in Allen and adjoining counties.......... 88

Suggestions for prospecting .............................. 89

Favorable structural conditions ....................... 89

Known areas of favorable structure .......................... 89

Search for other areas of favorable structure.......................

Extension of producing fields............................. 91

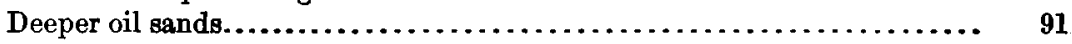

Production of oil $\ldots \ldots \ldots \ldots \ldots \ldots \ldots \ldots \ldots \ldots \ldots \ldots \ldots \ldots \ldots \ldots \ldots \ldots, \quad 92$

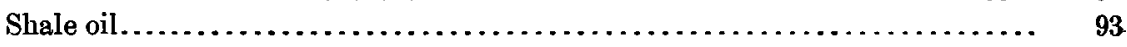

Notes on development........................................ 93

Well records..................................................... 94

Notes on adjoining counties.................................. 111

Barren County, Ky................................... 111

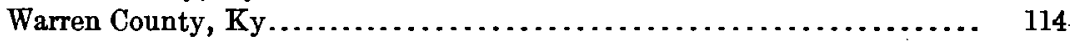

Simpson County, Ky ................................. 118

Sumner County, Tenn ................................ 119

Macon County, Tenn., and Monroe County, Ky ................. 120 


\section{IILUSTRATIONS.}

Prate . I. Geologic sketch map of region around Allen County, Ky ........

Page.

II. Geologic sketch map of a large part of Allen County, Ky., showing approximately areas underlain by various formations and the structure of a part of the area.......................

III. Exposures of "Corniferous" limestone, the oil "sand" of many Kentucky oil fields: $A$, Exposure on Big Trammel Creek $6 \frac{1}{2}$ miles south of Scottsville, Ky.; $B$, Exposure on Long Creek $1 \frac{1}{2}$ miles north of Holland, showing common tendency of limestone to weather to a deeply pitted surface; $C$, Detail from Long Creek exposure showing pits $A, B, C \ldots \ldots \ldots \ldots \ldots . . . .$.

IV. Original structural features of little or no value in oil and gas finding, shown in exposures in railway cut 1 mile south of

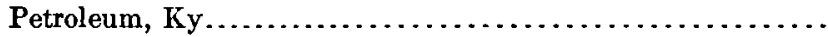

V. $A$, Geodes weathering out of Warsaw limestone near Halfway on Scottsville-Bowling Green pike, Allen County, Ky.; B, Local unconformity in St. Louis limestone (?) on ScottsvilleBowling Green pike about 15 miles west of Scottsville..........

VI. Sink holes of three kinds: $A$, Broad, shallow undrained sink hole, characteristic of surface underlain by Ste. Genevieve limestone, Scottsville-Bowling Green pike 2 miles east of Bowling Green; $B$, Deep, steep-sided undrained sink hole characteristic of surface underlain by St. Louis limestone, ScottsvilleBowling Green pike 11 miles west of Scottsville; C, Openthroated sink hole in St. Louis (?) limestone on ScottsvilleBowling Green pike 8 miles west of Scottsville.

VII. Sketch map showing farm lines and wells in the south-central

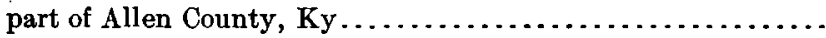

VIII. Structure map of main oil pools of Allen County, Ky ............

IX. Structural features developed through erosion and slumping and of no value in finding oil: $A$, St. Louis limestone exposure with two pseudo-anticlines near wells showing a little gas on Bowling Green-Scottsville pike at crossing of Drake Creek; $B$, Pseudoanticlines, synclines, and faults in uppermost part of black Chattanooga shale and overlying beds outcropping on east valley side of Long Creek near Holland; $C$, Near view of one of pseudo-anticlines of preceding view....................

X. Geologic map of Warren County, Ky ................. 114 
Figdre 1. Index map of Kentucky, Tennessee, and northern Alabama, show-

Page. ing the location of area briefly examined for this report and also the location of other oil fields and notable showings of oil in the region.

2. Geologic sketch map of Kentucky, Tennessee, and parts of adjoin-

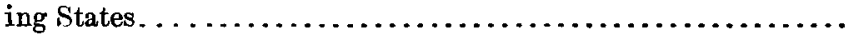

3. Diagrammatic section from Mississippi River northeast to the Hartford oil pool on the Rough Creek anticline, thence southeast to Allen County and east to Knox County.

4. Generalized section of rocks lying near the surface in the producing area of Allen County, Ky

5. Well sections illustrating character of oil-bearing strata in the North Petroleum oil field

6. Well sections illustrating character of oil-bearing strata in the Wildwood field.

7. Well sections illustrating character of oil-bearing strata on the Keen farm, Rodemer field.

8. Well sections illustrating character of oil-bearing strata on the Frost farm, Rodemer field.

9. Well sections illustrating character of "Corniferous" and Silurian limestones in different wells.

10. Diagram illustrating a feature that suggests an anticline or dome but that is really due to concave stream profile. 


\section{THE OIL FIELDS OF ALLEN COUNTY, KENTUCKY,}

WITH NOTES ON THE OIL GEOLOGY OF ADJOINING COUNTIES.

By E. W. Shaw and K. F. Mather.

\section{INTRODUCTION.}

FIELD WORK.

This report is based on a reconnaissance investigation of the oil field of Allen County, $\mathrm{K}_{\mathrm{y}}$., which was part of a broader study of the oil and gas fields of Kentucky, Tennessee, and Alabama, on which a general report is planned. Most of the field work was done by Mr. Mather, who spent three and a half weeks in and around the county. Mr. Shaw visited Scottsville, the county seat of Allen County, a few years ago and spent a few days in that vicinity at the beginning of the recent field work, which extended from the middle of April to the middle of May, 1917 He prepared also the first draft of the report and reviewed the literature, including reports in oil and gas journals.

The purpose of the field work was to investigate the geology of the county, particularly the structure or lay of the oil-bearing strata and the results of drilling to date. Structural conditions in the producing fields were determined by running level lines to the wells and correlating the data recorded in the well logs generously furnished by the operators. Traverses were made of outcrops, and observations of the dip and strike were made in different parts of the county. Lack of a topographic base map and of time and funds for making an accurate topographic survey render the results of the work somewhat incomplete, but it is hoped they will form a valuable contribution to the knowledge of the geology of this relatively little known region, for little detailed geologic work has been done heretofore within 50 miles of Scottsville.

The dips are generally too low to be read by the clinometer, but in some localities unmistakable dips can be observed in extensive outcrops along creek banks and can be measured with a level or hand transit. Few of the beds of this region can be followed any considerable distance, though by means of fossils the stratigraphic position of beds outcropping many miles apart can be determined 
vithin a few feet. The black shale is the best horizon marker, but it outcrops in only a few places and is reached in only a few wells outside the oil fields.

The field work thus consisted largely in observations on outcropping beds in different localities and in estimating the altitude of those identified, in collecting fossils for use in future detailed work, and in obtaining from oil operators data concerning the wells and their output. It included the determination of the general lay of the rocks in the county and surrounding territory and details of structure in certain areas. The rocks lie so nearly flat that without topographic data only the general dip could be made out for a large part of the area examined. A complete set of logs of wildcat wells in the region would have thrown much light on the structure and oil possibilities, but little is known of many of the earlier wells drilled in the region, especially of those altogether unsuccessful. An unsuccessful test is soon forgotten, though the data thus obtained concerning the depth at which different beds were found and the yield of porous strata, whether water, oil, or gas, is of great value to the geologist and oil prospector.

\section{ANNOTATED BIBLIOGRAPHY.}

The literature on the region in which Allen County, $\mathrm{Ky}$., is situated is relatively scant, and the following bibliography is believed to be practically complete except for articles in petroleum journals, particularly the Oil and Gas Journal, published in Tulsa, Okla., the Oil Trade Journal, published in Houston, Tex., and soil survey reports. Surveys of Warren County, Ky., and Sumner County, Tenn., both of which adjoin Allen County, have been made by the Bureau of Soils, United States Department of Agriculture.

1866.

Safford, J. M., Note on the geologic position of petroleum reservoirs in southern Kentucky and in Tennessee: Am. Jour. Sci., 2d ser., vol. 42, pp. 104-107.

The outcropping rocks in the region described are classified as follows:

7. Cosl measures, 400 feet, edge of table-land.

6. Mountain limestone, about 550 feet thick in Putnam County; mostly limestones.

5. Siliceous group; the "knobstones" of Kentucky. From 300 to 500 feet thick, including the Lithostrotion beds as its upper part.

4. Black slate, Devonian and Genesee, having a maximum thickness of about 60 feet.

3. Upper Silurian, mostly or wholly, from 100 to 150 feet thick, mostly a series of limestones, some of which are impure, approaching fine sandstone or shale in character. The existence of these strata in the region of Glasgow is mainly inferred from the fact that they are seen in certain sections to the northeast and eouthwest of this point. They are, however, comparatively unimportant, and thin out southeastward and disappear. 
2. Nashville group, Mr. Dana's IIulson period; blue fossiliferous limestones with some calcareous shales, 500 foet.

1. Trenton limestones at the base of the section.

"It may be remarked, in passing, that one of the most striking features of this section is the almost entire absence, of the Upper Silurian and Devonian formations. In the Tennessee and Cumberland river portions, the Upper Silurian beds are wholly wanting, while the Devonian series is represented by nothing more than the thin Black Slate-a fact pointed out by me many years ago."

Some oil is said to have been obtained from the "Mountain" limestone (St. Louis (?), particularly on Big South Fork of Cumberland River in Kentucky, near the Tennessee line, in a well known as the Beaty well. The top of the well is said to be about 50 feet below the top of the "Mountain" limestone and the bottom about 200 feet lower. "It was bored about 1825 for salt water. At its greatest depth a reservoir of oil was struck from which so much petroleum flowed as to lead to the abandonment of the boring as a salt well."

The Porter well in Allen County is described as an example of a well obtaining oil from "the Siliceous group." "Th.is woll is located un Bays Fork of Big P.arren on a line between Scottsville and Iioviling Green and about 7 miles from the former place and 18 from the latter. This reservoir was tapped sone time in January of this year (1866?) at the moderate depth of 55 feet. It yielded for a number of days by pumping about 100 barrels oi oil and strong brine per day: half of which was oil. At the time of ny visit, February 13 , it had produced altogether about a thousand barrels of petrole!nm but was not then doing well."

Oil is said to have been found in the black shale on Boyds Creek near Glasgow, though most of the oil in this district was found in the "Upper Silurian" just below the black shale. These wells range in depth from 60 to 250 feet and average about 130 feet.

"One of them was and nay be now a flowing well, having yielded for urany rnonths nearly, or quite, 30 barrels of oil per day. One or two of these borings may reach the next group of limestones below. In fact practically, and possibly in reality, the rocks unay be united with the Nashville group. * * * The Nashville group has furnished the wost and largest reservoirs."

"The old 'A merican oil well' near Burksville, originally bored for salt water, may be taken as an example. This from top to bottom is within the Nashville group. Its mouth is not far from $\mathbf{4 0}$ feet below the level of the Bluck Slate. At the depth of about 175 feet this boring tapped an oil reservoir from which flowed out, at a nininum: estimate, 50,000 barrels of oil."

It is said that no oil pools have been found in the "Trenton" or older rocks.

1867.

Hitchcock, C. H., Petroleum in North America: Geol. Mag., vol. 4, pp. 34-37.

Pefers to the occurrence of oil in Barren County in the following passage, which is of double interest because it is one of the earliest statements concerning the relation of oil pools to structural features:

"Petroleum may occur along lines of faults. Examples of this nature are in viestern Virginia, Cumberland and Earren counties, Ky., and elsewhere.

"Petroleum may exist in great quantities beneath anticlinal arches. * * * Examples of this nature are in Albert County, N. B., Caspe, C. F., and the productive region of Canada West. The roof acts as an impervion:s cover tu confine the fuids until the drill of the workman appears for their liberation. These facts show us where to expect petroleum in considerable amount." 
1877.

Davie, W. J., The resources and condition of the Commonwealth of Kentucky [Simpson, Warren, Barren, Allen, Monroe, and other counties]: Kentucky State Bur. Agr., Hort., and Stat., p. 76.

"T'he counties of Livingston, Crittenden, Lyou, Caldwell, I'rigg, Cbristian, Todd, Iogan, Simpinn, Warren, Mllen, Monme, Barren, and parts of Butler and Edmonson, lie upon what is known as the 'sub-Carhoniferous or cavernous limestone' formation, and contain much of the finest agricultural landa in the Mississippi Valley."

\section{8.}

Killebrew, J. B., Geology and topography of the oil region of Tennessee, with some account of the oil springa and wells: $\Lambda \mathrm{m}$. Assoc. $\Lambda$ dv. Sci. Proc., vol. 26, pp. 266-277.

The counties included in the oil region of Tennessee are listed, and among them is Sumner but not Macon, both of which join Allen County, $\mathrm{Ky}$., on the south. It is said that some petroleum has been found in each of the counties listed. The Devonian system in Tennessee is said to be represented only by black shale corresponding to the black Hamilton shale of New- York.

"Corniferous, Marcellus Portage, Chemung, and Catskill are all wanting; also the whole of the upper Silurian formations. The Upper Silurian appears w est of rrashville and to a liznited ex tent in the western part of Sumner County, where the Meniscus gray limestone of the Niagara epoch is present in considerable volume-estimated at 120 feet in thickness. It thins ont farther eastirard and totally disappears in the counties constituting the oil center."

The Mississippian series is referred to as the "Siliceous group," which falls into two divisions: "First, the Iithostrotion or coral beds; second, the lower Siliceous or Protean bed, which underlies the first." The Devonian black shale has a small area of outcrop, but "It is a very persistent formation and may" always be found throughout the State at its proper geologic horizon. Its usual thickness in the Tennessee oil region is from 26 to 35 feet." $\Lambda$ list is given of areas in which oil seeps out at the surface or has been found in wells.

"In Tennessee the oil finds a lodgment only in the crevices of rocks lying above or below the black shale. The wells will probably be quickly exhausted. There is wanting a porous absorptive sandstone surrounded by an inipervious formation to prevent leakage. The unusual number of oil springs shows that Nature bas not provided sufficient storage for her precious products."

1880.

Peckham, S. F., Report on the production, technology, and uses of petroleum and its products [Kentucky and Tennessee]; U. S. Tenth Census, 1880, vol. 10, pp. 24-25, map [oil regions of Kentucky and Tennessee], 1884.

Oil springs have been found on Paint Creek, in Johnson County; near Salyersville, in Magoffin County; and in Adair, Barren, Casey, Clinton, Cumberland, Edmonson, Green, Henderson, Lincoln, Metcalfe, Pulaski, Rockcastle, Russell, and Wayne counties. The specific gravity of the oil ranges from $25^{\circ}$ Baumé, near Monticello, to $26^{\circ}$ Baumé, east of Burkesville.

"The oil here appears to be in a sort of marble at 90, 190, and 380 feet from the surface." (P. 25.)

1890.

Fischer, Moritz, The oil fields of Parren County, Ky.: Eng. and Min. Jour., vol. 49, pp. 1.97-198.

Pescribes the oil region of southern Kertucky and northern Tennessee as being the nost promising in the United States, and of Barren and other counties to the east as having been the scene of active operations during the last two years. 
The first five or six wells drilled in the region are said to have been sunk near Boyds Creek in 1865 and to have each produced an average of three or four barrels a day since that time, the oil coming from close below the black shale. This pool has been called the Adams pool, and in about 1887 two other pocls were discovered as the result of prospecting stimulated by discoveries in northern Ohio. One of these, the Haven-Chase, was 9 miles northirest of the Adams pool, and another, the Carroll, was 5 miles southwest of the Haven-Chase. The following table gives the essential facts concerning these wells:

Well record of the Haven-Chase and Carroll groups.

\begin{tabular}{|c|c|c|c|c|c|}
\hline & $\begin{array}{l}\text { Depth of } \\
\text { well. }\end{array}$ & $\begin{array}{l}\text { Top of } \\
\text { black } \\
\text { shale. }\end{array}$ & $\begin{array}{l}\text { Produc- } \\
\text { tive } \\
\text { horizon. }\end{array}$ & Products. & Yield. \\
\hline $\begin{array}{r}\text { Haven-Chase group } \\
\text { North well..... } \\
\text { West well } \\
\text { South well..... } \\
\text { East well...... } \\
\text { Southeast weil. } \\
\text { South west well. }\end{array}$ & 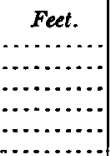 & $\begin{array}{r}\text { Feet. } \\
230 \\
225 \\
228 \\
225 \\
185 \\
200\end{array}$ & $\begin{aligned} & \text { Feet. } \\
& 307 \\
& 120 \\
& 120 \\
& 360 \\
& 310 \\
& 130\end{aligned}$ & 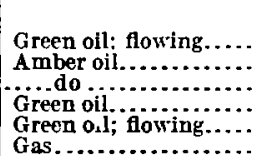 & $\begin{array}{l}50 \text { barrels. } \\
3 \text { barrels. } \\
10 \text { barrels. } \\
5 \text { barrels. } \\
3 \text { barrels. }\end{array}$ \\
\hline $\begin{array}{l}\text { Carroll group: } \\
\text { No.1............. }\end{array}$ & 875 & & 819 & nown. & Commercial quantities. \\
\hline $\begin{array}{l}\text { No. } 2 \ldots \ldots \ldots \ldots . \\
\text { No. } 3 \ldots \ldots \ldots . . .\end{array}$ & $\begin{array}{r}355 \\
7,135\end{array}$ & & $\begin{array}{l}355 \\
100 \\
715\end{array}$ & $\begin{array}{l}\text { Grcen oil } \ldots \ldots \ldots \ldots \ldots \\
\text { Amber oil } \ldots \ldots \ldots \ldots \ldots \\
\text { Gas } \ldots \ldots\end{array}$ & $\begin{array}{l}50 \text { barrels. } \\
\text { Small amount. } \\
\text { Commercial quantities. }\end{array}$ \\
\hline No. $4 \ldots \ldots \ldots$ & 750 & & $\begin{array}{r}1,135 \\
750\end{array}$ & $\begin{array}{l}\ldots \\
\cdots\end{array}$ & Do. \\
\hline No. 5.......... & 1,166 & & $\begin{array}{r}110 \\
1,166\end{array}$ & 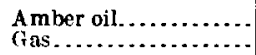 & $\begin{array}{l}\text { Small amount. } \\
\text { Do. }\end{array}$ \\
\hline
\end{tabular}

As in numerous other reports, the strata lying between the St. Louis limestone and the black shale are called the Keokuk group. Below the black shale the strata are identified successively as Niagara, Hudson River, and Trenton. The amber oil is said to come from the Keokuk, the green oil and gas from the "Hudson River." "It is possible that small stores of oil are held by the Niagara, but the main supply is most certainly derived from the Hudson River, this formation being also the productive one in the Burkville region, most of whose wells begin in it."

The thickness of the various formations is given as follows:

Thickness of formations underlying Barren County, $K y$.

Foet.

St. Louis.................................. 200

Keokuk................................... 250

Black shale...................................... 50

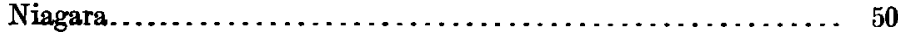

Hudson River................................ 800

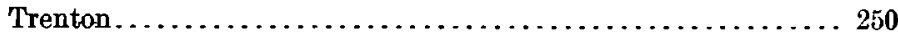

"The Keokuk amber oil is a semitransparent greenish-yellow and light oil. It is found some $\mathbf{1 0 0}$ feet above the black shale in the Haven group [of wells] and can possibly be obtained in larger quantities by passing the border of the St. Louis limestone.

"While the amber-oil horizon may prove a far more productive one than it is at present, the chief supply of this region is held by the Hudson River rocks, from which all these groups derive their oil. It is a dark-green to black fluid, very light, of $45^{\circ}$, characterized by a very strong odor. 
"The productive horizons of the Hudson River lie, reckoning from the base of the black shale, at the following depths:

All groups: Feet.

Green oil............................... $100 \pm$

Carroll groups:

Gas................................. 500

Gas................................. 950

"It follows that the oleiferous horizon is reached at the same depth by all wells. Apparent irregularities in its position are due to difference in elevation of the well heads and the slight dip of well strata westward. The presence of an attractive gas horizon 400 feet below the oil rock, and a second, a minor one, 450 feet below this, is suggestive, but our present knowledge of the field does not furnish explanation for this remarkable phenomenon."

The author evidently regards the oil as of animal origin and finds conditions most favorable to its formation and retention in pools in the "Hudson River group.".

"All factors essential to the production of oil are found in this group. Here is a series of limestone strata some 800 feet thick, almost entirely made of organic remains, porous enough to hold all stores of oil resulting from their decomposition, hermetically soaled by an impervious bed of shale 50 feet thick.

"The vitality of the wells supplied by the group is remarkable. For 25 years the Adams wells have faithfully produced their 20 barrels per day, a proud record but rarely achieved."

1891.

Kentucky Geol. Survey, Map of Warren County (geology by J. B. Hoeing).

$\Lambda$ map, published separately, with three cross sections and showing the areal geology of the county, on a scale of 2 miles to the inch.

Orton, Edward, Report on the occurrence of petroleum, natural gas, and asphalt rock in western Kentucky, based on examinations made in 1888 and 1889, Kentucky Geol. Survey, pp. 145-149.

Gives much information concerning the history of the oil industry. An extended quotation is given on pp. 18-20.

1895.

Weeks, J. D., Petroleum [Kentucky]: U. S. Geol. Survey Sixteenth Ann. Rept., pt. 4, p. 377.

In Allen County oil springs have been known to exist from its earliest occupation, being found in the lower part of the St. Louis limestone. One of the springs is in the valley of Trammel Fork of Drake Creek, a few miles southwest of Scottsville. "A barrel of this oil was shipped to Pittsburgh some time before 1850."

The old Burksville well is described. It is said to have been about 300 feet deep, and "the drilling tools were lifted out of the well by the force of the gas, and a column of oil was thrown to the top of the trees above the derrick. *** The well ceased to flow some three weeks after it was struck but remained full of oil and many years afterward was pumped for the purpose of obtaining oil to be bottled and sold for medicinal use. Though a good deal of drilling has been done in and around Burksville, nothing at all comparable to this early experience has been encountered, though small oil wells have been found.

"The largest oil field in the western half of Kentucky but still a very small oil field is in Barren County. Its early history agrees quite closely with that of Allen County, already given. Systematic drilling seems to have begun in this territory around Glasgow immediately after the war. The oil is black, with a specific gravity of $40^{\circ}$ to $42^{\circ} \mathrm{B}$. It does not contain an excessive amount of sulphur compounds. The surface rocks at this point (Boyds Creek) are the lowest beds of the Keokuk group, and the oil is derived from strata 177 feet below the valley level. The oil rock seems to be a sandstone." 
1897.

Oliphant, F. H., Petroleum [Kentucky]: U. S. Geol. Survey Eighteenth Ann. Rept., pt. 5 (continued), pp. 838-40.

Wayne and Barren counties are spoken of as the main producing counties of the State, though the production of each is low.

1898.

Oliphant, F. H., Petroleum [Kentucky]: U. S. Geol. Survey Nineteenth Ann. Rept., pt. 6 (continued), pp. 26, 95.

Speaks of some production in southern Kentucky from wells 18 to 20 years old near Glasgow from sands "at the bottom of the Mountain or sub-Carboniferous limestone, and possibly from the Corniferous limestone." Oil is said to have been found in 1829 in a well drilled for salt water near Burksville, 30 miles east of Allen County. "It flowed until 1860." The character of the material penetrated by the drill (in southern Kentucky) has indicated that it is not of the kind in which reservoirs of oil are usually found. In this year the marketed production of Kentucky is said to have been 322 barrels of oil, delivered on board cars at Glasgow.

1899.

Oliphant, F. H., Petroleum [Kentucky]: U. S. Geol. Survey Twentieth Ann. Rept., pt. 6 (continued), pp. $42-44$.

"There were some 13 wells producing near Oil City, Barren County, in 1898, being operated by the Interstate Petroleum Co. One of these wells during its life is said to have produced 40,000 barrels. The oil is found at 120,240 , and 325 feet. The deepest wells yield most of the petroleum, which is low in gravity, dark in color, and contains considerable sulphur. The oil is found in limestone, generally quite hard. In some instances an impure sand holds the petroleum" (p. 43).

1905.

Hoeing, J. B., Oil and gas sands of Kentucky: Kentucky Geol. Survey Bull. 1.

Discusses the stratigraphy and other features of oil and gas bearing strata in all parts of Kentucky and contains three maps showing the distribution of certain formations.

1911.

Munn, M. J., Preliminary report upon the oil and gas developments in Tennessee: Tennessee Geol. Survey Bull. 2-E, p. 33.

The following remarks are made concerning Macon'and Sumner counties, Tenn., which join Allen County, Ky., on the south:

"Macon County.-No drilling expressly for oil and gas has been reported from this county, though it is said that surface indications of both have been found at several places. Many years ago a shallow well is reported to have been drilled for brine near the site of Adams water mill, a few miles northwest of Lafayette, the county seat. This well is said to have encountered considerable quantities of oil at a few feet from the surface, but no authentic information regarding this is available. Within the last few years leases for oil and gas operations have been secured by operators on several large tracts of land in this county, but so far as known no development work has yet been done on them.

"Sumner County.-Three deep wells have been drilled in Sumner County in search of oil and gas. The first was drilled on the David Barrett farm, located near Rockbridge, in the central part of the county, about 15 miles north of Gallatin. This well is said by some to have reached a depth of 2,200 feet and by others to have been only 1,200 feet deep. All reports agree that sufficient gas was found to warrant its use for burning lime. A well drilled on the Turner property near Sugargrove, in the extreme northeastern part of the county, was a 
dry hole. In 1902 and 1903 a well, sunk about 2 miles southeast of Gallatin by local capital, reached a depth of about 1,200 feet, without finding more than slight shows of oil and gas. Just over the State line in Kentucky, opposite the northeast corner of Sumner County, a small oil pool has been developed at Petroleum, and since the same general geologic conditions seem to obtain over a large area here, it is probable that future testing will develop other pools of commercial size."

1913.

Crump, M. H., The oolitic limestones of Warren County: Kentucky Geol. Survey, 4th ser., vol. 1 , pt. 2 , pp. 1037-1049.

Discusses the character of the oolite and states that it commonly contains traces of petroleum.

$1053,1062$.

Kentucky rock asphalt: Kentucky Geol. Survey, 4th ser., vol. 1, pt. 2, pp.

"Kentucky rock asphalt is found principally along the southern and eastern outcrop of the western coal field of Kentucky. It has been opened and commercially developed in the counties of Edmonson, Warren, Logan, Breckinridge, and Grayson. It is known to outcrop in Hancock and Hardin and is reported in Hopkins. It is also found to a limited extent in northeastern Kentucky, notably near Soldier, on the Chesapeake \& Ohio Railway, in Carter County.

"The rock is very generally a sandstone which has been more or less saturated with petroleum, the latter (which completely coats each face of every individual grain of sand and thus forms a cementing material) being oxidized and the lighter oils driven off by exposure to the air. *** The percentage of bituminous matter contained varies from 5 to 21 per cent. *** The thickness of the beds runs from 3 to 30 feet, though it is reported as high as 40 feet in bored wells. * * *

"There are more than 100 openings in Grayson and Edmonson counties, from Grayson Springs along and on both sides of the divide between Bear Creek and Nolin River, where it is readily accessible to water transportation to the Ohio and thence throughout the Mississippi Valley."

1915.

Fohs, F. Julius, Oil and gas possibilities of Kentucky: Am. Inst. Min. Eng. Bull. 99, pp. 621-629.

Little is said specifically concerning Allen and adjoining counties, but they are represented on a map (fig. 2) "as probably not of value." Various formations are discussed as to their oil-bearing possibilities, and concerning the Western coal field and vicinity the following remarks are made:

The Pottsville sandstone gives little promise, though where it outcrops in Edmonson County it is asphaltic. Sandstones of the Chester group are not regarded as promising except in the interior of the coal field. They also are asphaltic at places along their outcrops. The Ste. Genevieve oolite [Fredonia oolite member] carries volatile petroleum near Bowling Green, and "should prove productive in the interior of the coal field." [The St. Louis is not mentioned.] The Keokuk carries oil at two places, one near the top and the other 80 feet above the black shale. [The black shale is not referred to as an oil reservoir.] The Corniferous, Niagara, and Clinton limestones [grouped together] are each 10 to 20 feet thick, are dolomitic, and lie 30 to 200 feet below the Ohio [Chattanooga] shale. The Cincinnatian rocks are regarded as rather unpromising. The Trenton limestone is nondolomitic "and hence will not produce oil." The Calciferous [St. Peter] "will later doubtless yield oil and gas." 
1918.

Leonard, W. C., Facts concerning the Kentucky oil fields; scientific reasons for the accumulation of oil in Kentucky and the probable location of undeveloped pools, 10 pp., map on cover.

Reviews the stratigraphy and general structure of a considerable part of Kentucky, including Allen and adjoining counties.

\section{ACKNOWLEDGMENTS.}

Special thanks are due to the many oil operators who gladly put at the disposal of the Survey all the data in their possession bearing on the geology of the district and expressed a willingness to collect additional information. The White Plains Oil \& Gas Co. in particular furnished facts of great value concerning a large number of wells. The State geologist, Mr. J. B. Hoeing, gave valuable data and suggestions and furnished altitudes which the State Geological Survey had determined of some of the earlier wells drilled in the county. His map of Warren County, which is northwest of Allen County, was also of value as a sidelight on the geology of Allen County. Col. M. H. Crump, of Bowling Green, generously offered a large fund of information which he had collected during many years of practical experience with the mineral resources of the region. Several commercial geologists, investigating the region for clients or employers at the time this report was being compiled, added greatly to its usefulness by their free discussion of the problems involved.

\section{GEOGRAPHY OF THE REGION.}

Location and area.-The geographic relations of the region under discussion are indicated in the index map (fig. 1). Allen County is adjacent to the Tennessee line a short distance west of the center of the southern border of Kentucky. It is traversed by the old State road which before the Civil War connected Louisville and the Blue Grass region to the northeast with Nashville to the southwest. The area of the county is 394 square miles.

Drainage.- The streams which drain Allen County are, from west to east, Middle Fork, Trammel Fork, Bays Fork, Long Creek, and intermediate streams. They flow northwest and north into Barren River, which forms the northern and northeastern border of the county. Barren River flows northwest through the center of Warren County to the northwest corner, where it joins Green River, which empties into the Ohio near Evansville, Ind.

The larger streams are for the most part in early maturity, having gentle gradients, 10 to 20 feet to the mile, through broadly U-shaped valleys. Barren River and Trammel Fork swing in graceful meandering curves from side to side of the valley flat, which along those streams is from a quarter to half a mile in width. Any of the rivers 


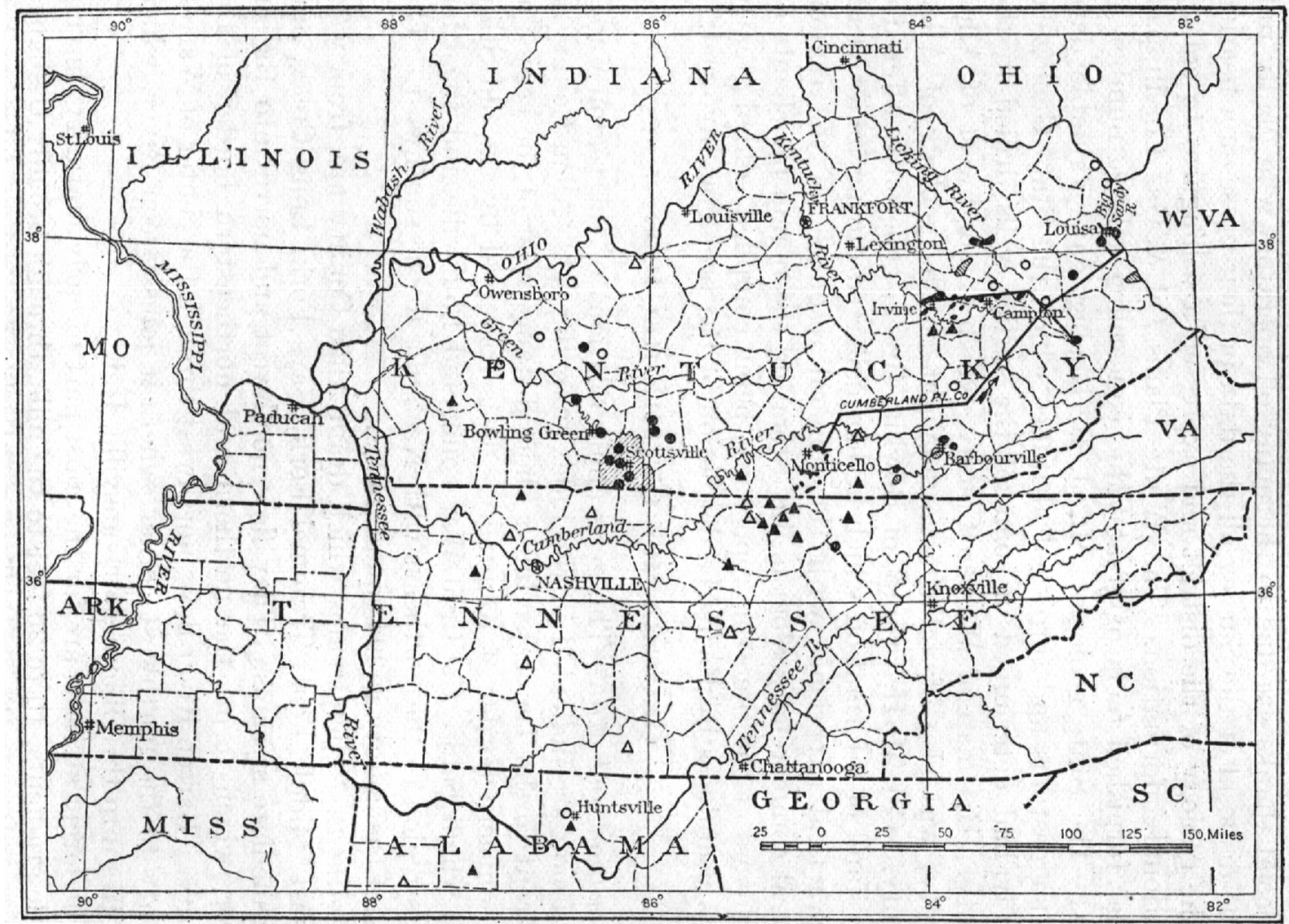

FIGURE 1.-Index map of Kentucky, Tennessee, and northern Alabama, showing the location of area brlefly examined for this report and also the location of other oil fields and notsble showings of oil to the reglon. 
and creeks may be safely forded, except in time of flood, almost anywhere along their courses. There are no falls nor rapids worthy of note in the county.

The presence of easily dissolved limestones in many localities has resulted in the development of numerous underground drainage lines and more or less extensive caverns, of which Mammoth Cave, 15 miles north of Allen County, is the most noted. Several streams in Allen - and adjacent counties disappear into caverns beneath the valley bottom and suddenly reappear a short distance down the valley as large springs. "Sinking Creek" and "Lost River" are common names in the limestone regions of Kentucky. One especially noteworthy example of this type of drainage is that of Long Creek, tributary to Barren River in the southeastern part of Allen County. At the big bend in this stream, nearly 2 miles north of Holland, the larger part of its water flows into a cave formed in the Devonian limestone beneath the black shale and reappears a third of a mile to the northeast, where it again becomes a surface stream. It is evident that in time the incised meander curve will be cut off by the diversion of the entire volume of Long Creek through this shorter channel.

Relief.-The surface is undulating or rough but nowhere mountainous. The uplands are comparatively uniform in height and somewhat flat or gently rounded. They are believed to be remnants of a plain into which the present valleys have been cut by streams. The relief is now 150 to 250 feet. In the northwestern half of the county there are comparatively few surface streams. The underlying rock is limestone that is relatively easily dissolved and sink holes are very numerous, giving a striking pitted appearance to the uplands between the tributaries of Barren River. The southeastern half of the county is more rugged and broken, small creeks and branches are abundant, and sink holes are almost entirely absent. Throughout both areas the divides and uplands are of similar height.

The full range in surface altitude extends from less than 500 feet above sea level along Barren River to over 800 feet at the higher points in the county.

Roads and towns in and near Allen County.-It is not difficult to build roads anywhere in the county, and natural supplies of excellent road dressing are abundant. The main roads show some tendency to follow divides but cross valleys at many places and at different angles. Some of them are well improved. The one between Scottsville and Bowling Green is kept in very good condition and is much used. An automobile stage makes two round trips over this 24-mile road each day. The main north-south road, from Adolphus through Scottsville and Cedar Springs, is a part of the Jackson Highway and connects $77677^{\circ}-19-$ Bull. $688 \longrightarrow 2$ 
Scottsville with Glasgow, the county seat of Barren County, 26 miles to the northeast. It is much used as an automobile route between Nashville and Louisville by way of Mammoth Cave.

The principal town in the region is Bowling Green, the county seat of Warren County, a city of about 10,000 people. Scottsville, the county seat of Allen County, had a population in 1910 of 1,400 people. Half a dozen villages are scattered about over the county, and small stores, some of them post offices, are much more numerous.

A branch line of the Louisville \& Nashville Railroad runs from Gallatin, Tenn., northeast 35 miles to Scottsville, and this is the only railroad outlet for the oil fields of the county. The main line between Louisville and Nashville runs through Bowling Green and Franklin, county seats of counties to the west of Allen, and another branch line leaves the railroad at Glasgow Junction, 25 to 30 miles north of Scottsville, and runs southeast to Glasgow, the county seat of Barren County. Eight counties lying east and southeast have no railroads.

\section{HISTORY OF THE OIL LNDUSTRY OF THE REGION.}

The history of the oil industry in Allen County preceding the year 1890 has been sketched by Edward Orton. ${ }^{1}$

Orton refers to the fact that this industry in the United States had its beginnings in about 1855 and in the few years that succeeded, prior to the outbreak of the Civil War. He says:

During the next four years there were many persons connected with the Federal armies passing acrose Kentucky whose interest in petroleum production had been already awakened and who consequently were sure to notice all the oil and gas springs along their various routes, and who also gathered up more or less of the traditions of the country in regard to these substances, as they had been brought to light in the search for salt water during previous years. When the war was over the results of these observations were to be seen in an invasion of Kentucky by representatives of the rapidly growing oil interests of the country, and drilling was begun at many points with great energy and with large expenditure of money, most of which came from the northern oil fields. The shrewd prospector saw or thought he saw many a new oil field among the secluded valleys of southern Kentucky and made haste to secure for himself a proper share of the wealth that lay hidden there. The period was one of great speculative excitement. The prospector was by no means a trained observer. Slight and unimportant resemblances to the productive oil fields of the East were seized upon and magnified into sure promises of fortune. An oil seep or a feeble gas spring was regarded as an infallible guide to a new Oil Creek.

Of this varied and enthusiastic exploration there remain small and in the main unimportant results. Not a single valuable oil field was brought to light by all this outlay of money and energy. Even the records of the work done have been mainly lost or, surviving only in the traditional form, they have already become indistinct and unreliable.

One of the districts that attracted great attention at the time and that was counted of unusual promise was the central portion of Allen County. Oil springs had been known in the region from the occupation of the country. ** * One spring of

\footnotetext{
1 Report on the occurrence of petroleum, natural gas, and asphalt rock in weatern Kentucky, based on examinations made in 1888 and 1889, pp. 145-149, Kentucky Gicol. Survey [1891?].
} 
this character is found in the valley of the Trammel Fork of Draked Creek, a branch of Barren River. It is located on the A. S. Walker land, a few miles to the southwest of Scottsville. The oil of this spring had long been collected in a small way, after the Indian fashion, by spreading a blanket over the surface of the spring and by wringing out the oil that was thus absorbed. A few barrelg were saved every year in this crude way. The Younglove Bros., druggists of Bowling Green, bought a barrel of the oil some time before 1850 and shipped it to Pittsburgh. The oil was prepared for the market by putting it up in pint bottles, and it found a ready sale throughout the country as already noted, for an external application in the case of wounds of both man and beast. A few barrels only of the oil from this region found their way to the regions outside. Another oil spring was known on Little Trammel Creek, near what is now designated as Petroleum station.

During the war, while the Confederate Army had possession of Bowling Green, 15 piles to the northwest, account was taken of these native sources of oil, and all that could be got was wagoned across the conntry and shipped to Memphis. It would appear that several shallow wells were drilled near the spring at this time, each of them yielding daily five to six barrels of heavy oil, but the accounts as to these occurrences are not entirely clear. The wells are said to have been from 600 to 700 feet deep. ${ }^{1}$

At the close of the war the district in which these oil springs were situated was leased by "prospectors" on the large scale for drilling purposes, but nothing more important than the results already named was secured, except in the single locality next to be described.

The Uriah Porter farm, 3 miles to the west of Scottsville, was long counted the finest and best improved farm of Allen County. It consisted of a thousand acres of land, much of it highly productive. In 1866 or 1867 Mr. Porter and his sons began the drilling of a well in the search for ail in the bottom lands to the southwest of the residence. At a depth variously reported in the traditions of the country, the range of the figures being between 75 and 300 feet, and the smallest figure being obviously nearest the facts, a flow of oil of extraordinary volume for this region was found. The production of the well was estimated by people who had never seen an oil well before as 500 barrels, 300 barrels, 200 barrels, 100 barrels per day. Large abatements from such estimates are generally required. At the outset some oil was wasted, but provision was forthwith made for the flow, and a total production of the well of not less than 100 barrels and probably twice or three times this amount was secured. The oil was shipped to Louisville and St. Louis for refining, but it was rank with sulphur and could not be deodorized by the means then at the refiner's command, and it was therefore counted of no value. Transportation was also very expensive, no railroad being reached within 15 miles. The horizon from which this well obtained its supply must have been the Keokuk group of the Subcarboniferous age.

This well naturally caused great excitement in the county and the surrounding region. It is said that an offer of $\$ 100,000$ was made by responsible parties for the farm and that this amount was refused. Two other wells were drilled by Mr. Porter, but both of them were failures. Another well was drilled in the vicinity upon the Mattley land, but it also was unproductive. The Younglove Bros., already named, bought a tract near the Porter farm and in connection with others drilled a well several hundred feet in depth. A little gas and a little oil were found but no value was developed in the well. On the Ham farm, 1 mile above Porter's, gas was struck, and its force was sufficient to blow the tools out of the wells, according to a tradition that still remaing here.

These accounts seem to exhaust the earlier history of the district with respect to petroleum. A new chapter begins with 1887. Drilling was once more resumed in the country and along the lines that had been already tested. The immediate im- 
pulse to these new tests came from the wonderful development of gas and oil in the Trenton limestone of northern Ohio and central Indiana. The possibility that this great stratum, which is known to underlie western Kentucky and as a rule within easy striking distance, contained like accumulations of stored power, proved enough to attract once more the oil interste of the country, or at least to stimulate local enterprise to make the search for this form of mineral wealth. During the last three years a considerable amount of drilling has gone forward in this general region, and preparations have been made for more, and in the large way, by leasing lands in large blocks. At least one new well has been sunk in Allen County during this time. The trarlitions of the Porter farm led its present owner, Col. E. L. Mottley, of Bowling Green, in 1887 to locate a new test well within 60 feet of the flowing well of 1866 . The work was done by the American Well Drilling Co. of Louisville. At 400 feet a show of oil was found, but the amount was not subsequently increased, though the drilling was continued to 1,300 feet. There was absolutely no value found in the series at this point. The Trenton limestone must have been passed through in the descent.

In 1903 a small company was organized in Franklin and an area of several thousand acres adjacent to the Walker springr, referred to in the above quotation from Orton, was leased. One well was drilled to a depth of 1,389 feet. Oil was struck at 288 feet, the horizon from which the present producing wells derive their supply; the report is that the well would have produced about 8 barrels a day, but the owners were hoping for much larger returns when the "Trenton" formation was penetrated. No accurate record is now available, but it is reported that the "Trenton" when reached was found to be hard and tight with no showing of oil. It had been intended to drill several test holes in the locality, but the project was abandoned, chiefly because of the large judgment awarded to the heirs of one of the drillers who was aocidentally killed during the sinking of the first hole.

In a report which appeared in 1905 , Hoeing ${ }^{1}$ shows an oil field just south of Glasgow, in Barren County, and another southwest of Burksville and extending into the eastern part of Monroe County, but the production of Allen County was evidently so low that no oil field is represented in it.

The general stimulation of the search for petroleum affected by high prices in recent years resulted in the drilling of half a dozen holes in various parts of the county in 1913. The results were so encouraging that drilling was continued on an increasing scale the following two years. One hundred and thirty wells are reported to have been sunk in 1916. More than three-fourths of these wells were successful, and their reported average initial production was 30 or 35 barrels. Partly on account of inadequate marketing facilities, however, the total marketed production of the field has not amounted to more than a few thousand barrels.

In 1917 the rate of drilling increased somewhat, and the percentage of successful wells fell off a little. A new pool east of Rodemer was

1 Hoeing, J. B., Oil and gas sands of Kentucky: Kentucky Geol. Survey Bull. 1, map 1, 1905. 
discovered early in the year, and the main development has been in that direction. Several wildcat wells have been sunk this year in distant parts of the county. The following statements have been published concerning the development of the field:1

The White Plains Oil \& Gas Co. is the largest operating concern in the county at this time and is known as the Snowden property. This company is operating and has drilled 59 wells on the following farms: V. A. Frost farm, 27 wells; M. B. Crow farm, 7 wells; Lon Richards farm, 3 wells; Taylor Jones farm, 2 wells; A. T. Hinton farm, 6 wells; J. W. Frost farm, 3 wells; Jim Knight farm, 2 wells; John Hornbuckle farm, 2 wells; and 1 each on the Lige Reynolds, Enoch Boucher, Charles Briley, Paul Miller, Younger Tabor, Price Watkins, and Emile Meredith farms.

The Ocala Oil Co., the second largest concern in the field, has drilled 19 wells. Of this number 12 are on the V. A. Frost farm, 2 each on the A. W. Duke and Perry Meador farms, and 1 each on the W. L. Nelson, Drew Deering, and George Hewitt farms.

The Petroleum Oil \& Gas Co. has 9 wells, 5 on the Charles Tucker, 3 on the Mack Cherry, and 1 on the McReynolds farm. The Atlas Oil Co. has 5 wells on the L. S. Barlow farm. The Southern Oil Co. (Barnsdall) has drilled 4 on the Denton Reeves farm, which includes the one drilled a few days ago.

The Good Luck Oil Co., under the management of John P. Hynds, has drilled 12 wells on the Martha Keen farm and 2 on the Bud Frost farm. The Republic Oil Co. has been in the field but a short time but has drilled 5 wells-1 on the Mose Fisher, 1 on the Bob Burton, 2 on the John Fishburn, and 1 on the Walker farm.

Kern and others have drilled but 1 well on the Grubbs farm but will soon start active work. The Great Southern Oil Co., while holder of some good-looking territory, has drilled 1 well and contracted for a large number to be started when the roads are in shape to move material. This company's well is on the T. J. Settle farm.

J. W. Boyd and others drilled 5 wells-3 on the J. W. Boyd and 1 each on the Tom Johnson and M. Read farms. The Banner Oil Co. drilled 2 wells on the R. E. Wilson farm. The Allen County Oil \& Gas Co. drilled 3 wells on the Jasper Cooper farm. The Barnett Oil Co. drilled 3 wells on the C. J. Guy farm. The Kenova Oil Co. drilled 2 welle on the Casper Cooper farm. The Alcoken Oil Co. drilled 1 well on the Dr. Graves farm. The McArthur Producing Co. drilled 1 well on the A. B. Miller farm. Huntsman \& Dixon drilled 1 well on the J. E. Rush farm, and Huntsman, Harkless \& Hinton drilled 1 well on the Albert Stamp farm.

The best of the late completed wells in the Scottsville field was the Republic Oil Co.'s No. 1 on the Mose Fisher farm, which is credited with a production of 200 barrels. The late completion of the Southern Oil Co. in No. 3 on the Denton Reeves farm shows that it will make a strong 15-barrel pumper and may increase with a shot. It is a!so reported that parties from Bowling Green, Ky., have drilled a 10-barrel pumper south of Petroleum at a depth of less than 100 feet.

The Republic Oil Co.'s test on the Walker farm had a showing of oil but has been listed with the failures. Another dry one that had a showing was the Long Creek Oil Co.'s test on the Jos. Meredith farm, far removed from production. The Petroleum Oil \& Gas Co.'s test on the Will Wygal farm had a light showing but has been abandoned, as the owners are looking for big wells. Sneed, McGuire, and others failed to find a paying producer on the $S$. J. Reed, which is the second well drilled on the farm. Turner Overman expects to drill to a greater depth on his well on the Overman farm. Aberling and others also failed to find a paying producer. These dry holes are located in advance of production.

Huntsman \& Dixon, two prominent Scottsville operators, have let a contract for drilling a well on the S. J. Thomas farm, in the Pope-Tramnel field, in the western part 
of Allen County. A. E. Aberling has let the contract for a test on the H. C. Dobbs farm, in the Holland district, about 6 miles southeast of Scottsville.

In covering Allen County as thoroughly as possible, since the late development started, but 36 dry holes were discovered, and they were scattered over a vast area of territory, although many of them had fair showings and might have produced a couple of barrels a day had they been given a trial. There are 18 firms or companies that have producing oil wells in Allen County. They are the White Plains Oil \& Gas Co. (the Snowdens), the Petroleum Oil \& Gas Co., the Atlas Oil Co., Southern Oil Co. (Barnsdall interests), Ocala Oil Co. (Huntsman interests), Good Luck Oil Co., Republic Oil Co., Great Southern Oil Co., Kern \& Co., J. W. Boyd \& Co., Banner Oil Co., Allen County Oil \& Gas Co., Barnett Oil Co., Kenova Oil Co., Alcoken Oil Co., MeArthur Producing Co., Huntsman \& Dixon, and Huntsman, Harkless \& Hinton.

There are 102 oil-producing wells in Allen County and a very low estimate of the production of these wells is 1,434 barrels a day. Oil men contend that the wells would produce close to 2,000 barrels if they could be pumped to their capacity. The wells when settled show wonderful staying qualities. Some wells much over a year old that started at 15 barrels are producing 10 barrels a. day regularly, and some that started at 10 barrels are doing a few more barrels, indicating the staying quality of the territory. About all the oil that is shipped from the field at this time goes by tank cars to the little refining plant at Nashville, Tenn., and some to the Indian Refining Co., at Lawrenceville, Ill., the latter from the wells of Snowden Bros. or the White Plains Oil Co. The Nashville plant is located about 60 miles south and a little west of the Scottsville field and was constructed by John Hynes, a well-known oil man, and his assaciates, who control the Good Luck Oil Co. and other producing companies in the Scottsville field.

In the drilling of wells in the Scottville field one can readily figure the cost. Contractors receive $\$ 1.50$ per foot, with drilling machines, which saves the cost of derricks. It requires around 10 feet of drive pipe, which is usually the 8-inch, and from 20 to 60 feet of 6 -inch casing.

In May, 1917, practically the entire county was under lease and plans were being matured for systematic prospecting by some of the larger oil companies in regions which have so far received little attention. It is unlikely that any large bodies of oil will remain undiscovered in the county after the fall of 1918.

\section{DISTRIBUTION AND EXTENT OF THE OLL FLELDS.}

The developed fields of Allen County extend, with some interruptions, from Scottsville to Petroleum and are separated by barren strips into five well-defined pools. The Scottsville field includes the producing wells within the limits of the city and those along the west fork of Bays Fork, half a mile to the southwest. The Rodemer pool is west of the railroad station of Rodemer, 3 miles southwest of the county seat. The newly discovered pool east of Rodemer may be called the Wildwood pool, from the railroad stop with that name half a mile northwest of the field. Farther to the southwest is the North Petroleum pool, and closely adjacent to the town of Petroleum is the South Petroleum pool. These names will be used in this report, the term "pool" being applied to the oil underground and the term "field" to the area on the surface known to be underlain by oil. 
Good showings of oil are reported in wells in other parts of the county, and it is likely that some of these areas will be soon developed into other oil fields. Among these areas the most promising is on Rough Creek, $4 \frac{1}{2}$ miles south of Scottsville, where several wells on the Burd Miller and W. H. Miller farms are now being rigged for pumping. This oil pool, if such it proves to be, may be known as the Turlock pool, from the post office of that name formerly located within a stone's throw of the wells.

Some oil is present beneath the Cal Guy farm, on Trammel Fork, 7 miles west of Scottsville, and in a well on the Moore farm northeast of Cedar Springs. Tests in the eastern part of the county have so far been entirely unsuccessful, but additional drilling is contemplated there.

\section{GEOLOGY.}

\section{GENERAT FEATURES.}

Allen County is in the midst of a great area in which the outcropping rocks belong to the Mississippian series or the lower part of the Carboniferous system. (See fig. 2.) The St. Louis limestone, which with some associated rocks is known to drillers in many parts of the country as the Big lime, crops out on the hilltops in the western part of the county, and cherty limestones representing the underlying Warsaw, Keokuk, Burlington, and possibly Kinderhook appear at innumerable places in the eastern half of the county. On the opposite side of Warren County, to the northwest, is the edge of an area of coal-bearing rocks which extends northwestward for more than 200 miles, covering many counties in Kentucky, Indiana, and Illinois. About 50 miles to the east is the border of the great Appalachian coal basin, which extends from Alabama through Tennessee, Kentucky, and West Virginia to northern Ohio and Pennsylvania. The coal-berring rocks belong in the middle part of the Carboniferous system, known as the Pennsylvanian series. About 50 miles to the northeast is the edge of the Blue Grass region, which owes its general character to the Ordovician limestone that underlies its surface and that crops out there because the earth's crust in that region has been bent upward in a great arch known as the Cincinnati anticline. The edge of a similar area of uplift, which is known as the Nashville dome and which covers many counties, lies 10 or 15 miles to the southwest.

Allen County thus occupies a saddle or low place on an anticline of very great extent or it may be considered to lie structurally between two very broad, low domes. However, the close proximity of the county to the Nashville dome places it not in the bottom of the saddle but on the southern side, which is rising toward the crest of the arch in Tonnessee. The strata underlying this region therefore dip downw ard with considerable uniformity toward the north and northwest. Their 


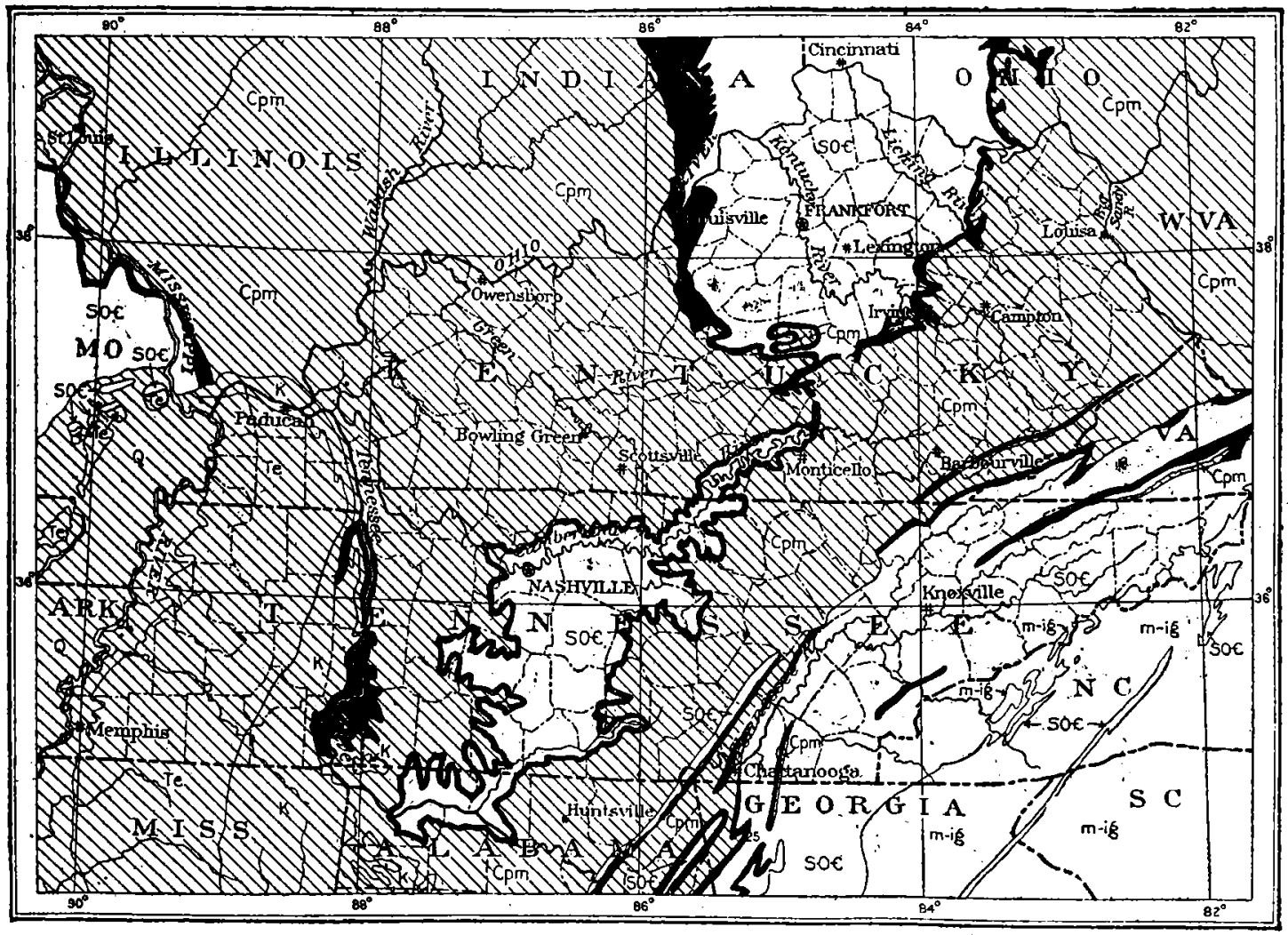

EXPLANATION

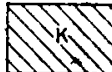

Cretaceous

FraURx 2.-Geologic sketch map of Kentucky, Tennessee, and parts of adjoining States showing by shading the area underlain by Devonian slrata. 


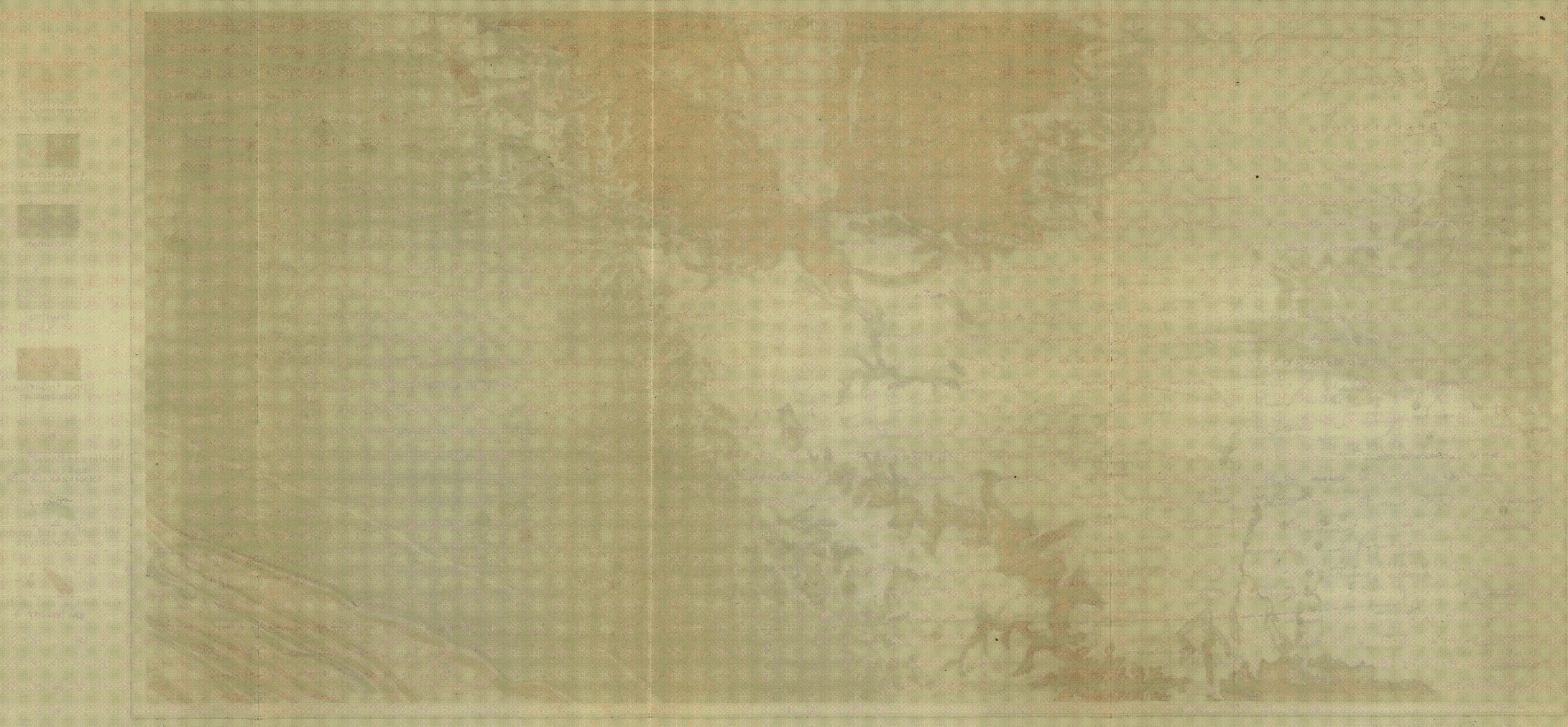


general attitude is monoclinal with a gentle rise toward east and south. These structural relations are illustrated in the section (fig. 3 ), which indicates also the general character of thestrata, in particular lithologic variations within the Mississippian series and the thickening of certain beds, in particular the Devonian and Silurian, away from the axis of uplift.

The geologic relations of the region are shown in greater detail on Plate I and the areal geology of Allen County on Plate II.

\section{STRATIGRAPHY.}

UNEXPOSED ROCKS.

GENERALIZED SECTIONS AND WELL RECORDS.

A question which arises sooner or later in every oil field, and one of increasing importance as the years go by and the supplies of petroleum fail more and more to meet the demand, is, What chance is there of finding oil reservoirs below the present productive sands in the known fields? It is common for an oil field to produce for a time from one sand and then for other rich sands lying at greater depths to be found. The greatest depth from which oil may be recovered is not yet determined. Because of this question information concerning Ordovician and Silurian strata which underlie the known oil-bearing rocks of Allen County becomes of great importance. Beds which may form oil reservoirs are of course of especial interest, but others for which casing must be prepared and other drilling plans made are also worthy of description. Such beds are likely to include limestones as well as sandstones, for many of the limestones of Kentucky are porous and in places cavernous.

Knowledge concerning the nature of these underlying beds is not very definite. Perhaps the best descriptions are to be found in reports covering distant areas in thesamegeneral region, among which should be mentioned in particular reports on the Columbia quadrangle, Tenn.; the lead, zinc, and fluorspar region of western

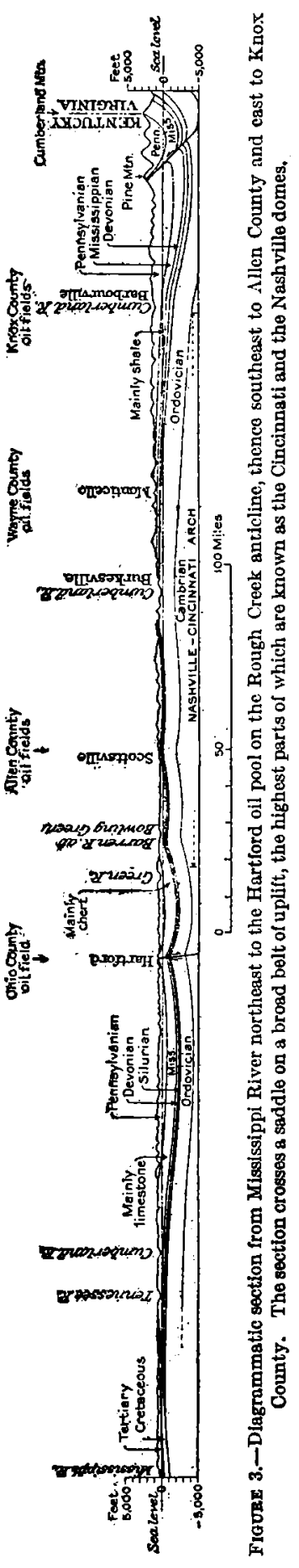

1 Hayes, C. W., and Ulrich, E. O., C. S. Geol. Surrey Geol. Atlas, Columbia folio (No. 95), 1903. 
Kentucky; ${ }^{1}$ Jefferson County, $\mathrm{Ky}_{.} ;{ }^{2}$ and the Blue Grass region, $\mathrm{Ky} .{ }^{\mathrm{a}}$ The areas described in these reports are, however, so far distant that the rocks may be quite different from thase in Allen County. Logs of some deep wells near the county will partly supply the need for more exact information.

A generalized section for the Columbia quadrangle, which lies 15 to 50 miles southwest of Nashville, is given below:

Generalized section of the rocks of the Columbia quadrangle, Tenn."

\begin{tabular}{|c|c|c|c|}
\hline System and series. & Formation. & $\begin{array}{l}\text { Thick- } \\
\text { ness. }\end{array}$ & Character. \\
\hline \multirow[t]{2}{*}{$\begin{array}{l}\text { Carboniferous (Missis- } \\
\text { sippian). }\end{array}$} & \multirow{2}{*}{$\begin{array}{l}\text { St. Lovis limestone. } \\
\text { - Inconformity } \\
\text { Tullahoma formation. } \\
\text { - Inconformity }\end{array}$} & $\begin{array}{l}\text { Fect. } \\
250\end{array}$ & $\begin{array}{l}\text { Gray and blue thick-bedded fossiliferous lime- } \\
\text { stone, generally very cherty; chert in largo } \\
\text { pieces and solid, except in the basal part, } \\
\text { where it is cellular. }\end{array}$ \\
\hline & & $0-250$ & $\begin{array}{l}\text { Greenish clay shale at the bottom, followed } \\
\text { by extremely cherty shale and cherty lime- } \\
\text { stone above; chert clayey and in small pieces }\end{array}$ \\
\hline Devonian. & \multirow{2}{*}{$\begin{array}{l}\text { Chattanooga shale. } \\
\text { Cnconfornity } \\
\text { Clifton limestone. }\end{array}$} & $0-10$ & $\begin{array}{l}\text { Black carbonaceous shale, generally with a } \\
\text { phosphatie band at the base and a ghau- } \\
\text { conitic green shale, containing phosphatio } \\
\text { nodules, at the top. }\end{array}$ \\
\hline Upper Silurian. & & $0-60$ & $\begin{array}{l}\text { Even bedded dense light-gray or bluish lime- } \\
\text { stone, commonly thin bedded and in places } \\
\text { shaly in the lower part. }\end{array}$ \\
\hline \multirow{7}{*}{ Ordovician. } & Fernvale formation. & $0-40$ & $\begin{array}{l}\text { Soft green and chocolate shales and red ferru- } \\
\text { ginous crystalline limestone, commonly con- } \\
\text { taining greenish specks, and some of it con- } \\
\text { glomeratic and phosphatic. }\end{array}$ \\
\hline & \multirow{2}{*}{$\begin{array}{l}\text { Leipers formation. } \\
\text {-Unconformity } \\
\text { Catheys formation. }\end{array}$} & $0-100$ & $\begin{array}{l}\text { In eastern half of quadrangle knotty, earthy } \\
\text { limestone at the top, nith similar but more } \\
\text { shaly and highly lossiliferous beds below. } \\
\text { In western half nearly uniform granular } \\
\text { crystalline limestone, the more granular por- } \\
\text { tions highly phosphatic. }\end{array}$ \\
\hline & & $0-100$ & $\begin{array}{l}\text { Shales and knotty limestones, usually under- } \\
\text { lain by heavy-bedded suberystalline lime } \\
\text { stone and overlain by fine-grained blue and } \\
\text { earthy limestones, separated by thin seams } \\
\text { of shale; all more or less highly fossiliferous. } \\
\text { Basal part in places includes some granular } \\
\text { phosphatic layers. }\end{array}$ \\
\hline & Bigby limestone. & $\mid 30-100$ & $\begin{array}{l}\text { Generally nearly uniform granular, crystalline, } \\
\text { laminated, phosphatic limestone; the upper } \\
\text { part commonly shaly or arenaceous, the } \\
\text { lower part in many places having beds of } \\
\text { shales but never sandy. }\end{array}$ \\
\hline & \multirow{2}{*}{$\begin{array}{l}\text {-Hermitage formation. } \\
\text {-Unconformity } \\
\text { Carters limestone. }\end{array}$} & $40-70$ & $\begin{array}{l}\text { Even-bedded, alternating thin layers of argil- } \\
\text { laceous or siliceous limestone and shale in } \\
\text { lower third, and siljeeous subgranular lime- } \\
\text { stone more or less strongly phosphatic in the } \\
\text { middle and upper parts. }\end{array}$ \\
\hline & & $40-60$ & $\begin{array}{l}\text { Heavy-bedded, fine-grained, white or light- } \\
\text { blue limestone, in many places containing } \\
\text { chert and silicified fossils. }\end{array}$ \\
\hline & Lebanon limestone. & $70-100$ & $\begin{array}{l}\text { Thin-hedded, commonly shaly, fine-grained } \\
\text { bluish or dove-colored limestone, in many } \\
\text { places weathering yellow. }\end{array}$ \\
\hline
\end{tabular}

1 Ulrich, E. O., and Smith, W. S. T, The lead, zine, and fuorspar deposits of western Kentucky: U. S. Geol. Survey Prof. Paper 3i, 218 pp., 15 płs., 1905.

2 Butts, Charles, Geology and mineral resources of Jefferson County, Ky.: Kentucky Geol. Survey, 4th ser., vol. 3, pt.' 2,270 pp., 65 pls., map 1015.

Matson, G. C. Water resources of the Blue Grass region, Ky.: U. s. Geol. Survey Water-Supply Paper 23., pp. 14-17, 1909 . 3, 1 Hayes, C. W., and Ulrich, E. O., U. S. Geol. Survey Geol. Atlas, Columbia folio (No. 95), pp. 1, 2, 


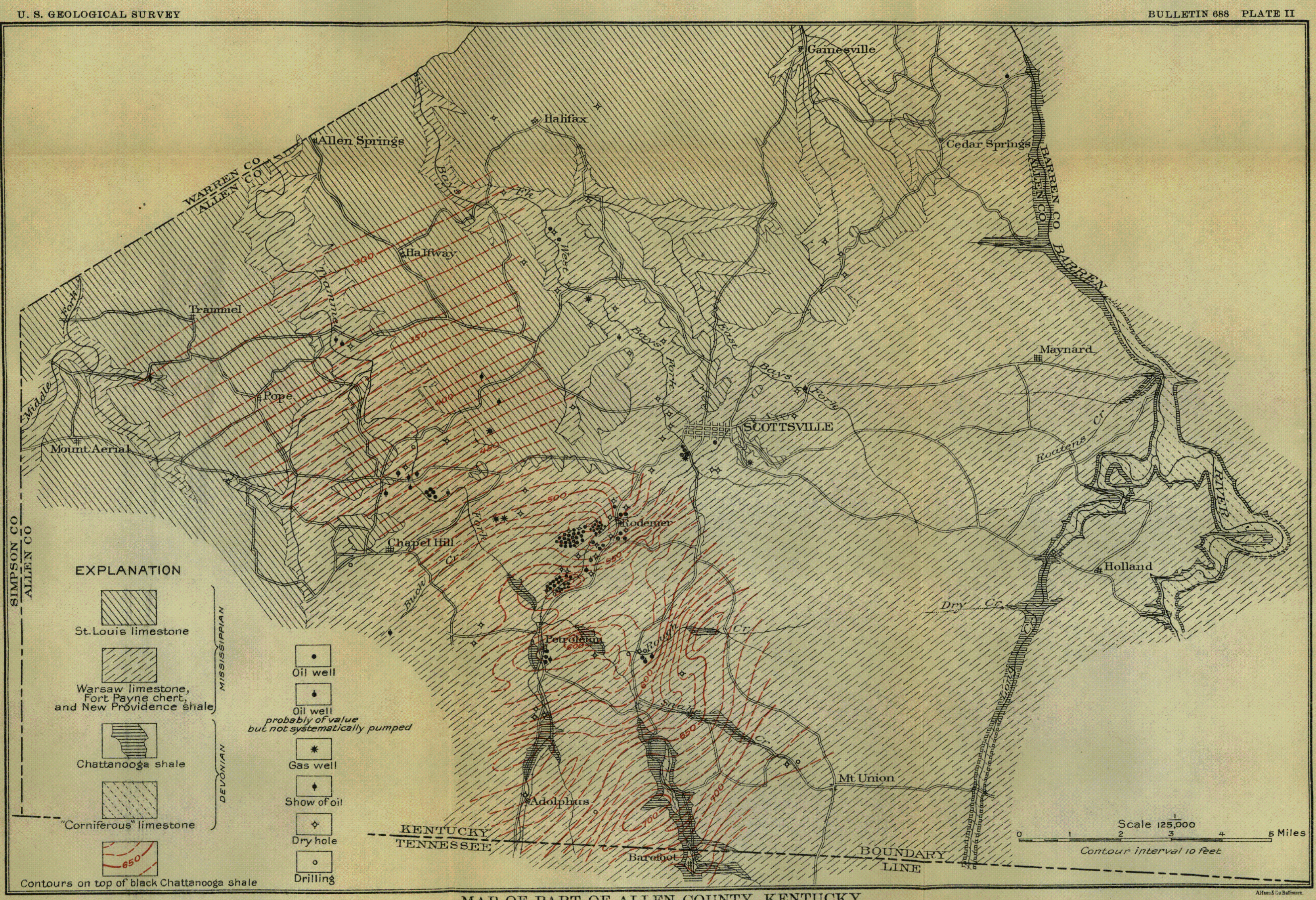

SHOWING GHOLOGIC FORMATIONS, STRUCTURE CONTOURS ON TOP OF CHATTANOOGA SHALF, AND OIL AND GAS BORINGS 


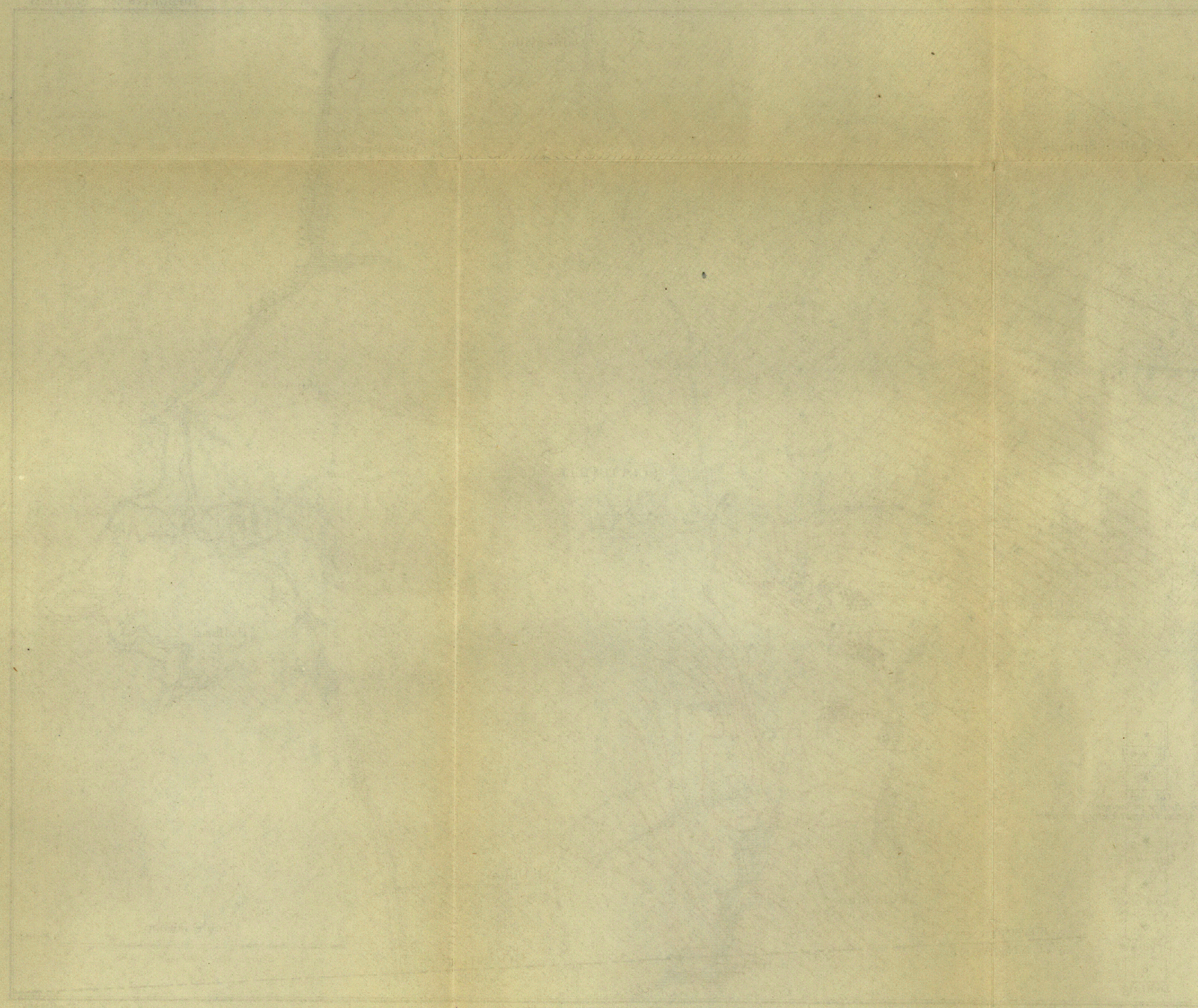


As indicated in the column showing thickness, many of the forme tions are absent in places, having been eroded away before succeed? ing formations were laid down. Hayes and Ulrich give one section in which the St. Louis limestone rests upon the Bigby limestone, six formations between being absent. This section is just south of Duck River, opposite Wisner Hill, and is as follows:

Feet.

St. Louis limestone . . . . . . . . . . . . . . . . . . . . . . . $25 \pm$

Bigby limestone (lowermost part) $\ldots \ldots \ldots \ldots \ldots \ldots \ldots \ldots \ldots \ldots, 30 \pm$

Hermitage formation................................... $50 \pm$

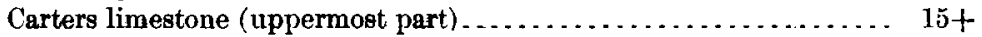

Generalized section of the rocks in Breckinridye and adjoining counties in Kentucky. ${ }^{a}$

\begin{tabular}{|c|c|c|c|c|c|c|}
\hline $\begin{array}{l}\text { Sys- } \\
\text { tem. }\end{array}$ & $\begin{array}{l}\text { Se- } \\
\text { ries. }\end{array}$ & \multicolumn{2}{|c|}{ Group and formation. } & Character. & $\begin{array}{l}\text { Thick- } \\
\text { ness. }\end{array}$ & Equivalents. \\
\hline \multirow{9}{*}{ 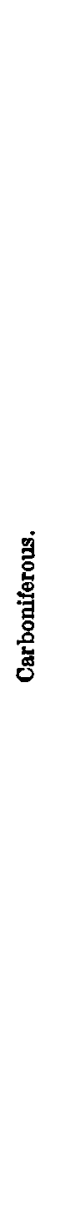 } & 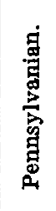 & \multicolumn{2}{|c|}{ Pottsville group. } & $\begin{array}{l}\text { Sandstone, shale, and } \\
\text { conglomerate, with } \\
\text { here and there a coal } \\
\text { bed. }\end{array}$ & $\begin{array}{l}\text { Feet. } \\
150\end{array}$ & $\begin{array}{l}\text { Equivalent to a part of the } \\
\text { Pottsville group lnown } \\
\text { throughout a wide anea } \\
\text { in the eastern and cen- } \\
\text { tral parts of the United } \\
\text { States consisting genc- } \\
\text { ally of sandstone, some } \\
\text { conglomerate, shale, and } \\
\text { coal. }\end{array}$ \\
\hline & \multirow{8}{*}{ 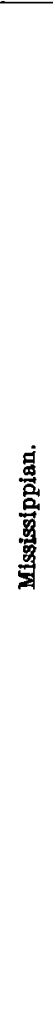 } & \multirow{7}{*}{ 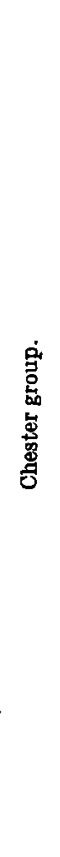 } & $\begin{array}{l}\text { Unconformity- } \\
\text { Buffalo W a } 110 \mathrm{~W} \\
\text { formation. }\end{array}$ & $\begin{array}{l}\text { Mainly shale, with a few } \\
\text { beds of limestone and } \\
\text { sandstone. }\end{array}$ & 150 & $\begin{array}{l}\text { Equivalent to the Clore } \\
\text { formation, Palestine } \\
\text { sandstone, and Menard } \\
\text { limestone of Crittenden } \\
\text { Connty, Ky., and the } \\
\text { region to the northwest. }\end{array}$ \\
\hline & & & $\begin{array}{l}\text { Tar Springs sand. } \\
\text { stone. }\end{array}$ & $\begin{array}{l}\text { Sandstone with some } \\
\text { limestone and calcare- } \\
\text { ous sandstone. }\end{array}$ & 50 & $\begin{array}{l}\text { Equivalent to the Tar } \\
\text { Springs sandstone of } \\
\text { southeastern Ilinois } \\
\text { and adjoining portion } \\
\text { of Kentucky. }\end{array}$ \\
\hline & & & $\begin{array}{l}\text { Glen Dean lime- } \\
\text { stone. }\end{array}$ & $\begin{array}{l}\text { Thin to thick bedded } \\
\text { limestone with some } \\
\text { shale. }\end{array}$ & 120 & $\begin{array}{l}\text { Equivalent to the Glen } \\
\text { Bean limestone of west- } \\
\text { eru Kentucky and } \\
\text { southeasternIllinois and } \\
\text { to a part of Okaw forma- } \\
\text { tion of southwestern } \\
\text { Illinois. }\end{array}$ \\
\hline & & & $\begin{array}{l}\text { Hardinsburg sand- } \\
\text { stone. }\end{array}$ & $\begin{array}{l}\text { Generally flaggy sand- } \\
\text { stone. }\end{array}$ & $50+$ & $\begin{array}{l}\text { Equicalent to a portion } \\
\text { of the okaw formation } \\
\text { of southwestern Illinois, } \\
\text { or to an unconformity } \\
50 \text { feet }+ \text { below its top. }\end{array}$ \\
\hline & & & $\begin{array}{c}\text { Golconda forma- } \\
\text { tion. }\end{array}$ & $\begin{array}{l}\text { Thick to thin bedded } \\
\text { limestone. }\end{array}$ & 50 & $\begin{array}{l}\text { Equivalent to lower part } \\
\text { of Okaw formation. }\end{array}$ \\
\hline & & & $\begin{array}{l}\text { Cypress ("Big } \\
\text { cfifty") sand- } \\
\text { stone. }\end{array}$ & Massive sandstone. & 80 & $\begin{array}{l}\text { May be in part equivalent } \\
\text { to sandstones in upper } \\
\text { part of Ruma formation. }\end{array}$ \\
\hline & & & $\begin{array}{l}\text { Gasper oolite with } \\
\text { s a m p l e sand- } \\
\text { stone member in } \\
\text { lower hall. }\end{array}$ & $\begin{array}{l}\text { Mainly oolitic limestone } \\
\text { with some shale and } \\
\text { sandstone. }\end{array}$ & 150 & $\begin{array}{l}\text { Upper part equivalent to } \\
\text { the Ridenhower shalo } \\
\text { of southern Illinois. }\end{array}$ \\
\hline & & 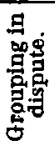 & $\begin{array}{l}\text { Ste. Gene ple vo } \\
\text { limestone (m a y } \\
\text { belong in Chester } \\
\text { group), Fredonia } \\
\text { olite member. }\end{array}$ & $\begin{array}{l}\text { Oolitic and geodifer- } \\
\text { ons (?) limestono. }\end{array}$ & 160 & $\begin{array}{l}\text { Equivalent to lower part } \\
\text { of Ste. Genevieve lime } \\
\text { stone of region to west } \\
\text { and northwest. }\end{array}$ \\
\hline
\end{tabular}

a Butts, Charles, Kentucky Geol. Survey Bull.-(in press); also Kentucky Geol. Survey, vol. 3, pt. 2, pp. 59-168, 1915. 
Generalized section of the rocks in Breclinridge and adjoining counties in KentuckyContinued.

\begin{tabular}{|c|c|c|c|c|c|c|}
\hline $\begin{array}{l}\text { Sys- } \\
\text { tem. }\end{array}$ & $\begin{array}{c}\text { Se- } \\
\text { ries. }\end{array}$ & \multicolumn{2}{|c|}{ Group and formation. } & Character. & $\begin{array}{l}\text { Thick- } \\
\text { ness. }\end{array}$ & Equivalents. \\
\hline \multirow{7}{*}{ 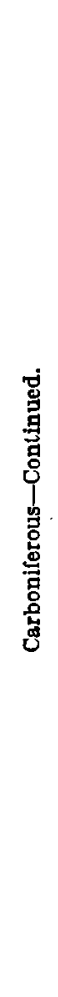 } & \multirow{7}{*}{ 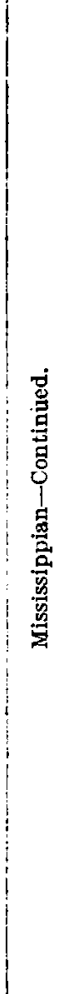 } & \multirow{3}{*}{ 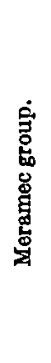 } & $\begin{array}{l}\text { St. Louis lime- } \\
\text { stone. }\end{array}$ & $\begin{array}{l}\text { Very chert } \text {, geodiferous, } \\
\text { massive limestone. }\end{array}$ & $\begin{array}{l}\text { Fet. } \\
500\end{array}$ & $\begin{array}{l}\text { Equivalent to St. Louis } \\
\text { limost one, know } \\
\text { throughout a wide re- } \\
\text { gion in the central part } \\
\text { of the Mississippi basin. }\end{array}$ \\
\hline & & & Spergen limestone. & Massive pure limestone. & 20 & $\begin{array}{l}\text { Equivalent to Spergen } \\
\text { limestone of Illinois and } \\
\text { Indiana. }\end{array}$ \\
\hline & & & Warsaw limestone. & $\begin{array}{l}\text { Limestone more or less } \\
\text { argillaceous and in } \\
\text { places cherty. }\end{array}$ & 80 & $\begin{array}{l}\text { Equivalent to the War- } \\
\text { saw limestone of the cen- } \\
\text { tral portion of the Mis- } \\
\text { sissippi basin. }\end{array}$ \\
\hline & & \multirow{4}{*}{ 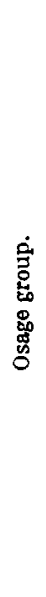 } & $\begin{array}{l}\text { Holtzclaw s a n d- } \\
\text { stone. }\end{array}$ & Massive sandstone. & 15 & $\begin{array}{l}\text { Probably equivalent to } \\
\text { the uppermost part of } \\
\text { the Keokuk limestone } \\
\text { and upper part of Fort } \\
\text { Payne chert. }\end{array}$ \\
\hline & & & Rosewood shale. & $\begin{array}{l}\text { Mainly shale with a } \\
\text { little limestone. }\end{array}$ & 190 & $\begin{array}{l}\text { Equivalent to the main } \\
\text { part of the Keokuk lime- } \\
\text { stone of Illinols, lowa, } \\
\text { Missouri, and elsewhere, } \\
\text { and to the Fort Payne } \\
\text { ("Tullahoma") ch e rt } \\
\text { of Tennessee and ad- } \\
\text { joining territory. }\end{array}$ \\
\hline & & & $\begin{array}{l}\text { Kenw o od sand- } \\
\text { stone. }\end{array}$ & $\begin{array}{l}\text { Thin beds of sandstone } \\
\text { with some shale. }\end{array}$ & 40 & $\begin{array}{l}\text { Equivalent to a portion } \\
\text { of the Keokuk and Fort } \\
\text { Payne. }\end{array}$ \\
\hline & & & $\begin{array}{l}\text { New Providence } \\
\text { shale. }\end{array}$ & $\begin{array}{l}\text { Soft greenish clay shale } \\
\text { with local highly fos- } \\
\text { siliferous thin lime- } \\
\text { stone layers in the } \\
\text { middle. }\end{array}$ & 150 & $\begin{array}{l}\text { Approximately equiva- } \\
\text { fint to the Burlington } \\
\text { limestone. }\end{array}$ \\
\hline \multirow{3}{*}{$\begin{array}{l}\text { 总 } \\
\text { : } \\
\text { คे }\end{array}$} & & New & Albany shale. & $\begin{array}{l}\text { B l a ck carbonaceous } \\
\text { shale. }\end{array}$ & 100 & $\begin{array}{l}\text { Equivalent to a part of the } \\
\text { Chattanooga shale of } \\
\text { Alabama, Tennessee, } \\
\text { and Kentucky and the } \\
\text { Ohio shale of Ohio and } \\
\text { adjoining territory. }\end{array}$ \\
\hline & & \multicolumn{2}{|c|}{$\begin{array}{l}\text { Sellersberg limestone: } \\
\text { Beechwood limestone } \\
\text { member. } \\
\text { Silver Creek limestone } \\
\text { member. }\end{array}$} & $\begin{array}{l}\text { Gray, thick-bedded, } \\
\text { rather coarse; con- } \\
\text { tains many crinoid } \\
\text { stems. } \\
\text { Thick-bedded,dark-gray, } \\
\text { fine-grained siliceous } \\
\text { and aluminous mag- } \\
\text { nesian limestone. }\end{array}$ & $10+$ & $\begin{array}{l}\text { Generally regarded } \\
\text { Hamilton in age. }\end{array}$ \\
\hline & & \multicolumn{2}{|c|}{ Jeffersonville limestone. } & $\begin{array}{l}\text { Thin to thick bedded } \\
\text { hard limestone with } \\
\text { more or less chert. } \\
\text { The lower part in par- } \\
\text { ticular contains many } \\
\text { coral fossils. }\end{array}$ & 20 & $\begin{array}{l}\text { Approximately equivalent } \\
\text { to the Columbus lime- } \\
\text { stone of Ohio and the } \\
\text { Onondage "Cornifer- } \\
\text { ous") limestone of New } \\
\text { York andelsewhere, this } \\
\text { being the oil sand of } \\
\text { many fields of Ken- } \\
\text { tucky. }\end{array}$ \\
\hline
\end{tabular}


Generalized section of the rocks in Breckinridje and adjoining counties in Kentucky Continued.

\begin{tabular}{|c|c|c|c|c|c|}
\hline $\begin{array}{l}\text { Sys- } \\
\text { tem. }\end{array}$ & $\begin{array}{l}\text { Se- } \\
\text { ries. }\end{array}$ & Group and formation. & Character. & $\begin{array}{l}\text { Thick- } \\
\text { ness. }\end{array}$ & Equivalents. \\
\hline \multirow{5}{*}{ 总 } & \multirow{5}{*}{-} & Iouisville limestone. & $\begin{array}{l}\text { Thick-bedded medium- } \\
\text { grained bluish-gray } \\
\text { limestone; upper part } \\
\text { cherty; uppermost } 5 \\
\text { to } 8 \text { feet highly fossllif- } \\
\text { erous. Important } \\
\text { quarry rock for build- } \\
\text { ing stone and road } \\
\text { metal. }\end{array}$ & $\begin{array}{l}\text { Feet } \\
45-100\end{array}$ & $\begin{array}{l}\text { May be in part equivalent } \\
\text { to Lockport dolomite or } \\
\text { include slightly later } \\
\text { beds. }\end{array}$ \\
\hline & & Waldron shale. & $\begin{array}{l}\text { Bluish calcareous and } \\
\text { magnesian shale; fos- } \\
\text { sils very scarce. }\end{array}$ & 10 & \\
\hline & & I.aitrel dolomite. & $\begin{array}{l}\text { Medium thick-bedded, } \\
\text { rather fine-grained } \\
\text { bluish gray, highly } \\
\text { magnesian limestone; } \\
\text { fossils very scarce; im- } \\
\text { portant quarry rock. }\end{array}$ & 40 & $\begin{array}{l}\text { Probably nearly equiva- } \\
\text { lent to Lockport dolo- } \\
\text { mite. }\end{array}$ \\
\hline & & Osgood formation. & $\begin{array}{l}\text { Blue calcareous shales } \\
\text { and modium-grained } \\
\text { limestones; u p p e r } \\
\text { shale with many cal- } \\
\text { cite inclusions up to } \\
\text { severalinches in diam- } \\
\text { eter; also shale with a } \\
\text { bed of red shale near } \\
\text { the bottom. }\end{array}$ & 30 & $\begin{array}{l}\text { Rochester shale; member } \\
\text { of Clinton formation. }\end{array}$ \\
\hline & & Brassfeld limestone. & $\begin{array}{l}\text { Coarse crystalline, yel- } \\
\text { low mottled, fossilifer- } \\
\text { ous limestone. }\end{array}$ & $0-10$ & $\begin{array}{l}\text { Believed to represent some } \\
\text { of the Albion sandstone } \\
\text { of Medina group. }\end{array}$ \\
\hline \multirow{4}{*}{ 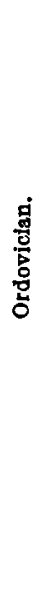 } & \multirow{4}{*}{ 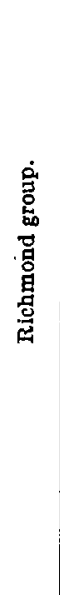 } & Saluda limestone. & $\begin{array}{l}\text { Thick-bedded, fine- } \\
\text { grained, highly mag- } \\
\text { nesian, sandy lime- } \\
\text { stone with blue fine- } \\
\text { grained limestone at } \\
\text { the top. }\end{array}$ & $30-35$ & \multirow{4}{*}{$\begin{array}{l}\text { Queenston shale and Ju- } \\
\text { Diata formation. }\end{array}$} \\
\hline & & Liberty formation. & $\begin{array}{l}\text { Thin limestone inter- } \\
\text { bedded in blue clay } \\
\text { shale; highly fossilif- } \\
\text { erous. }\end{array}$ & $35-50$ & \\
\hline & & Waynesville limestone. & $\begin{array}{l}\text { Mainly thick-bedded } \\
\text { limestone weathering } \\
\text { gray; } 10 \text { feet of greenish } \\
\text { shale with abundant } \\
\text { globular bryozoans at } \\
\text { one horizon. }\end{array}$ & 10 & \\
\hline & & Armheim formation. & $\begin{array}{l}\text { Thin, blue, irregularly } \\
\text { surfaced limestone in- } \\
\text { terbedded in blue clay } \\
\text { shale; fossils very } \\
\text { abundant. }\end{array}$ & $80-100$ & \\
\hline
\end{tabular}


Generalized section in western Kentucky.a

\begin{tabular}{|c|c|c|c|c|c|c|c|}
\hline $\begin{array}{l}\text { Sys- } \\
\text { tem. }\end{array}$ & \multicolumn{2}{|c|}{ Series. } & Group. & \multicolumn{2}{|c|}{ Formation. } & $\begin{array}{l}\text { Thick- } \\
\text { ness. }\end{array}$ & Character. \\
\hline \multirow{8}{*}{ 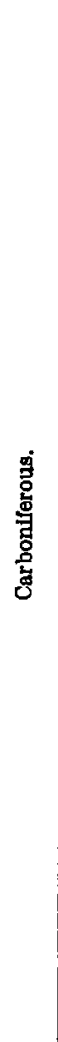 } & \multicolumn{2}{|c|}{$\begin{array}{l}\text { Pennsylva- } \\
\text { nian. }\end{array}$} & Pottsvillo. & \multicolumn{2}{|c|}{ Mansfield sandstone. } & $\begin{array}{l}\text { Feet. } \\
100\end{array}$ & $\begin{array}{l}\text { Sandstone, conglomerate, } \\
\text { and shale. Equivalont to } \\
\text { Mansfield sandstone of of } \\
\text { Indians, Coal Measures } \\
\text { conglomerate of various } \\
\text { parts of Kentucky, and a } \\
\text { part of the Pottsvillegroup } \\
\text { of eastern and central } \\
\text { United States. }\end{array}$ \\
\hline & \multirow{7}{*}{ 兽 } & \multirow{4}{*}{ 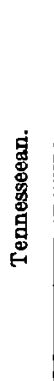 } & \multirow{4}{*}{ Chester. } & \multirow{2}{*}{$\begin{array}{l}\text { Kagkastia } \\
\text { limestone. }\end{array}$} & $\begin{array}{l}\text { B i rdsrille } \\
\text { formation. }\end{array}$ & $400-180$ & $\begin{array}{l}\text { Shale, sandstone, and lime- } \\
\text { stone. }\end{array}$ \\
\hline & & & & & $\begin{array}{l}\text { Tribune } \\
\text { limestone. }\end{array}$ & $100-200$ & Mainly limestone. \\
\hline & & & & \multicolumn{2}{|c|}{ Cypress sandstone. } & $60-135$ & Massive sandstone. \\
\hline & & & & \multicolumn{2}{|c|}{$\begin{array}{l}\text { Ste. Genevieve lime- } \\
\text { stone. }\end{array}$} & $144-145$ & $\begin{array}{l}\text { Mainly oolitic limestone (in- } \\
\text { cludes Ohara limestone } \\
\text { Rosiclare sandstone, and } \\
\text { Fredonia oolitic limestone } \\
\text { members). }\end{array}$ \\
\hline & & \multirow[b]{3}{*}{$\frac{\sum_{j}}{3}$} & & \multicolumn{2}{|c|}{ St. Louis limestone. } & $300-400$ & $\begin{array}{l}\text { Heavy hedded, very eherty } \\
\text { limestone. }\end{array}$ \\
\hline & & & & \multicolumn{2}{|c|}{ Spergen limestone. } & $100 \pm$ & Oolitic, pure limestone. \\
\hline & & & Kinderhook. & \multicolumn{2}{|c|}{$\begin{array}{l}\text { Tultahoma formation. } \\
\text { Equiralent to Keokuk } \\
\text { and Burlington lime- } \\
\text { stones and Kinder- } \\
\text { hook group. Fquiva- } \\
\text { lent also to Harrods- } \\
\text { burg limestone and } \\
\text { Knobstone of Indians. }\end{array}$} & $200-250$ & $\begin{array}{l}\text { The Tullahoma formation in } \\
\text { this district is at the bot- } \\
\text { tom a gray clayey shale } \\
\text { that farther upward grad- } \\
\text { ually includes more and } \\
\text { more siliceous and calcaro- } \\
\text { ous matter until from } \\
\text { about the middle of the } \\
\text { formation upward it is a } \\
\text { highly siliceous and more } \\
\text { or less earthy limestone. }\end{array}$ \\
\hline 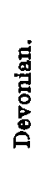 & & & Chemung. & \multicolumn{2}{|l|}{ Ohio shadt } & & $\begin{array}{l}\text { Black carbonaceons shale. } \\
\text { Equivalent to the New } \\
\text { Albany shale of Indiana, } \\
\text { the Chattanooga shale of } \\
\text { eastern Tennessee, the } \\
\text { Grassy Creek shale of } \\
\text { Keyes, and the Ohio shalo } \\
\text { of Ohio. }\end{array}$ \\
\hline
\end{tabular}

a Ulrich, E. O., and Smith, W. S. T., The lead, zine, and fluorspar deposits of western Kentucky: U.S. Geol. Survey Prof. Paper 36, pp. 24-70, 1905. 
Generalized geosagic section in the Blue Grass region, $\boldsymbol{K}_{y} \cdot a$

\begin{tabular}{|c|c|c|c|}
\hline System. & Formation. & $\begin{array}{l}\text { Thick. } \\
\text { ness. }\end{array}$ & Character. \\
\hline Carboniferous. & Waverly shale. & $\begin{array}{l}\text { Feet. } \\
300\end{array}$ & $\begin{array}{l}\text { Contains beds of greenish sandstone which; where near the } \\
\text { surface, yiedd excellent soft water. The shale furnishes } \\
\text { no water. }\end{array}$ \\
\hline Deronian. & Ohio shale. & 150 & $\begin{array}{l}\text { In shallow wells it yields an abundance of highly mineral } \\
\text { ized water. The most common mineral waters are sul- } \\
\text { phur, chalybeate, and alum. }\end{array}$ \\
\hline \multirow{2}{*}{$\begin{array}{l}\text { Devonian and } \\
\text { Silurian. }\end{array}$} & \multirow[t]{2}{*}{ I'anola. } & 30 & $\begin{array}{l}\text { Usually a cherty magnesian limestane with some shale } \\
\text { beds. In deep wells yields moderate quantities of mag; } \\
\text { nesian water. ["Corniferous" limestone, the oil "sand" } \\
\text { of many Kentucky fields.] }\end{array}$ \\
\hline & & 60 & $\begin{array}{l}\text { Blue shales and yellow limestones, in places containing } \\
\text { chert. Locally includes some sandstone. In deep wells } \\
\text { the limestones furnish considerable water in some locali- } \\
\text { ties. }\end{array}$ \\
\hline \multirow{12}{*}{ Ordovician. } & \multirow{3}{*}{$\begin{array}{l}\text { Richmond forma- } \\
\text { tion. }\end{array}$} & $60 \pm$ & $\begin{array}{l}\text { Upper division: Heavy bedded gray or blue arenacoous } \\
\text { fmestones, about } 10 \text { feet of dense calcareous shale in } \\
\text { lower part. Locally an impure sandstone. Sandy por- } \\
\text { tions yield a little water in some places. }\end{array}$ \\
\hline & & 125 & $\begin{array}{l}\text { Middle division: Blue shale with some blue or dove-col- } \\
\text { ored limestone. Rarely yields water. }\end{array}$ \\
\hline & & 80 & $\begin{array}{l}\text { Iower division: Interbedded blue limestone and shale. } \\
\text { May occasionally yield some sulphur, brackish, or salt } \\
\text { water. }\end{array}$ \\
\hline & $\begin{array}{l}\text { Maysville forma- } \\
\text { tion. }\end{array}$ & 230 & $\begin{array}{l}\text { Interbedied blue limestones and shales, the alternato } \\
\text { layers usually thin and nodular. Beds usually thin. } \\
\text { Seldom yields water at depths greater than } 150 \text { feet. } \\
\text { Water is apt to be brackish and cantain hydrogen sul- } \\
\text { phide. }\end{array}$ \\
\hline & Eden shale. & $200+$ & $\begin{array}{l}\text { Mainly bluish shale, but upper part is commonly sandy } \\
\text { (Garrard sandstone) and the most sandy portions gener- } \\
\text { ally yield water. }\end{array}$ \\
\hline & $\begin{array}{l}\text { Winchester lime- } \\
\text { stone. }\end{array}$ & $60+$ & $\begin{array}{l}\text { Generally vields moderate amounts of strong brines, with } \\
\text { more or less hydrogen sulphide. }\end{array}$ \\
\hline & \multirow{3}{*}{$\begin{array}{l}\text { Lexington lime- } \\
\text { stone. }\end{array}$} & 75 & $\begin{array}{l}\text { Upper division: Gray, crystalline, and oherty (Flanagan } \\
\text { chert member). Commonly yields much salt or saline- } \\
\text { sulphur water. }\end{array}$ \\
\hline & & 194 & $\begin{array}{l}\text { Middle division: Light drab argillaceous limestone with } \\
\text { shale beds. Uppermost part, } 20 \text { to } 60 \text { feet thick, is com- } \\
\text { monly gandstone with some phosphatic limestone. } \\
\text { Yields strongly mineralized water, usually salt or salt- } \\
\text { sulphur. }\end{array}$ \\
\hline & & 30 & $\begin{array}{l}\text { Lower division: Heavy bedded coarse-grained crystal- } \\
\text { line and cherty limestone. Yields a little salt-sulphur } \\
\text { water. }\end{array}$ \\
\hline & $\begin{array}{l}\text { Highbridge lime- } \\
\text { stone. }\end{array}$ & 400 & $\begin{array}{l}\text { Mainly limestone, with shale lenses here and there. Little } \\
\text { or no sandstone. Yields moderate amounts of salt and } \\
\text { salt-sulphur water, especially from near top. }\end{array}$ \\
\hline & $\begin{array}{l}\text { Unidentified lime- } \\
\text { stone. }\end{array}$ & 100 & Similar to Highbridge limestone. \\
\hline & $\begin{array}{l}\text { St. Peter sand- } \\
\text { stone. }\end{array}$ & & $\begin{array}{l}\text { A siliceous limestone yielding large quantities of salt-sul- } \\
\text { phur water. Thickness unknown. }\end{array}$ \\
\hline
\end{tabular}

a Matson, G. C., Water resources of the Blue Grass region, Ky.: U. S. Geol. Survey Water-Supply Paper 223, pp. 14-17, 1909. 
J. B. Hoeing ${ }^{1}$ classifies the first 1,600 feet of rocks below the Devonian shale in Wayne County, 50 miles east of Allen County, as follows:

Classification of rocks below the Devonian shale in Wayne County, Ky., according to J. B. Hoeing.

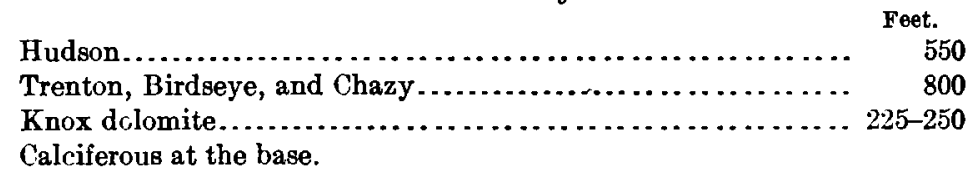

Foerste ${ }^{2}$ gives the following classification of the Ordovician rocks of eastern Kentucky:

Foerste's classification of the Ordovician rocks of eastern Kentucky.

\begin{tabular}{|c|c|c|c|}
\hline System. & Series. & Formation. & Subdivision. \\
\hline \multirow{5}{*}{ Ordovician. } & \multirow{4}{*}{$\begin{array}{l}\text { Cincinnatian (Hudson } \\
\text { River group of former } \\
\text { reportsof Kentucky sur- } \\
\text { vey). }\end{array}$} & Richmond. & 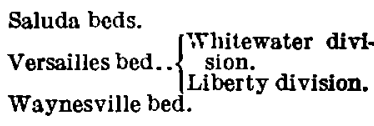 \\
\hline & & Maysville. & $\begin{array}{l}\text { Arnheim bed. } \\
\text { Mount Auburn bed. } \\
\text { Corryville bed. } \\
\text { Bellevue bed. } \\
\text { Fairmont bed, including Tate layer } \\
\text { in upper balf. } \\
\text { Mount Hope bed. }\end{array}$ \\
\hline & & Eden. & $\begin{array}{l}\text { Paint Lick bed, or Upper Eden. } \\
\text { Million bed.. \{Middle Eden. } \\
\text { Lower Eden. }\end{array}$ \\
\hline & & Cynthiana & $\begin{array}{l}\text { Fulton or Triarthrus becki layer. } \\
\text { Point Pleasant bed. } \\
\text { Greendale bed. }\end{array}$ \\
\hline & $\begin{array}{l}\text { Jessamine (corresponding } \\
\text { approximately to the } \\
\text { Mohawkian rocks of } \\
\text { New York). }\end{array}$ & $\begin{array}{l}\text { Lexington. } \\
\text { Highbridge. }\end{array}$ & \\
\hline
\end{tabular}

The Lexington formation, as classified above, corresponds to the Trenton of former reports of the Kentucky Survey, and the Highbridge formation, which is of Stones River and Black River age, corresponds to the Birdseye and Chazy rocks of former reports of that Survey.

1 Hoeing, J. B., Kentucky Geol. Survey Bull. 1, p. 42, 1905.

2 Foerste, A., Kentucky Geol. Survey Bull. 7, pp. 13, 19, 1906. 
Ulrich classifies the Ordovician rocks of the Cincinnati dome as follows: ${ }^{1}$

Ulrich's classification of the Ordovician rocks of the Cincinnati dome.

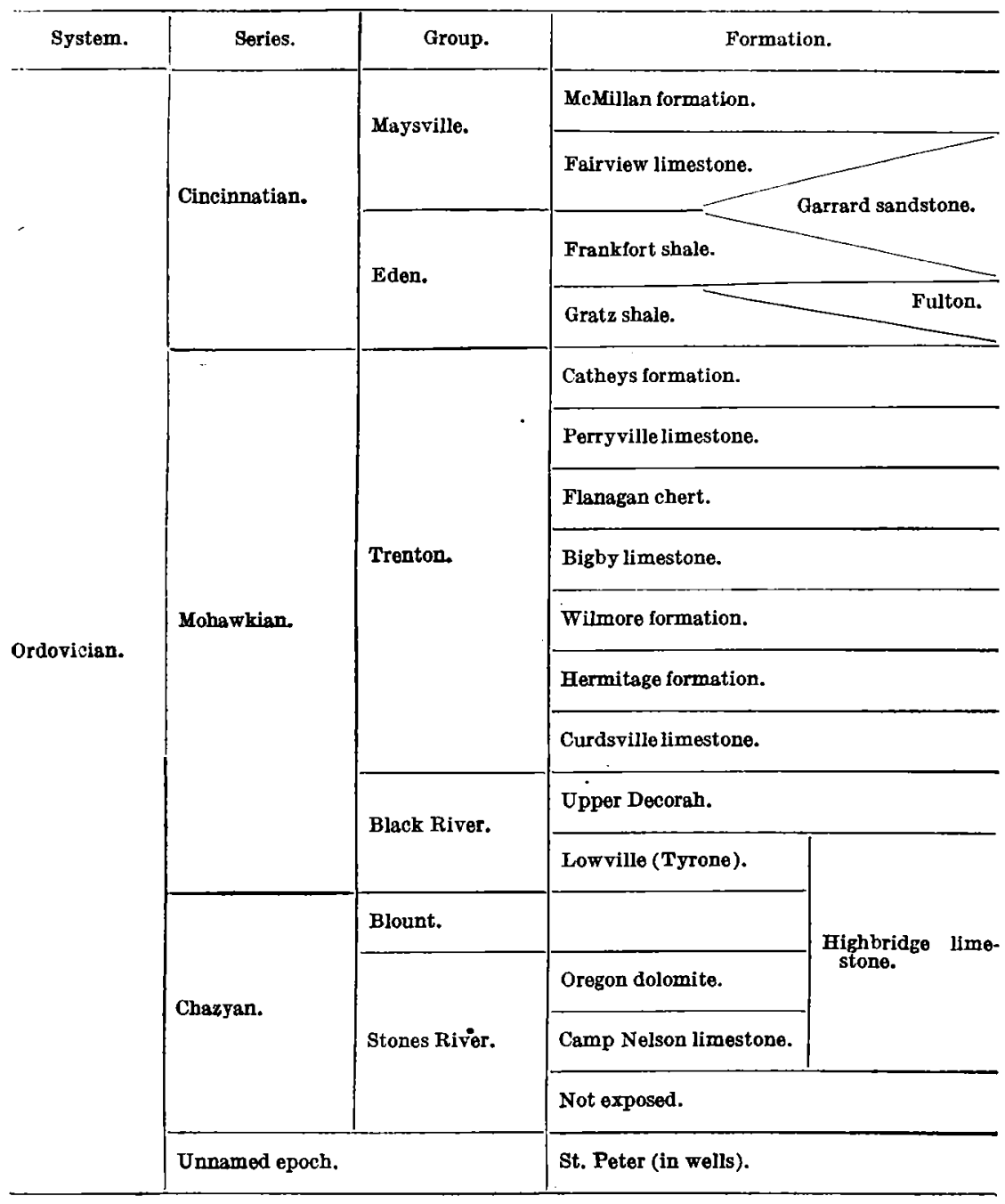

A later report by Ulich ${ }^{2}$ gives a slightly different classification of the upper part of this section.

1 Ulrich, E. O., Gool. Soc. America Bull., vol. 22, p. 608, 1911.

I Ulich, E. O., The Ordovician-Silurian boundary: Cong. geol. internat., 12th sess., 1913, Compt. rend., pp. 593-667, 1914.

$77677^{\circ}-19-$ Bull. $688-3$ 
The following record of a deep well at Bowling Green is given by Hoeing. The geologic interpretation of the log is based on Hoeing's statement.

[Ste. Genevieve limestone:]

\section{Partial record of well at Bowling Green, Ky.}

[Figures indicate depth in feet.]

Surface, oolite, white.

18,25 , and 30 , limestone, gray.

36 , oolite, light gray.

42 , limestone, fine grained, white.

[St. Louis limestone:]

46-i0, limestone, very fine grained, white siliceous.

77 , limestone, fine grained, slightly oolitic, gray.

90 , limestone, gray.

94, limestones, white and light gray, mixed.

98, limestone, light gray.

100 , limestone, white.

106, limestone, light brown.

112, limestone, light mottled.

117, limestone, gray and calcite, white.

130, limestone, fine grained, gray.

135, limestone, gray.

140, limestone, gray crystalline.

144, limestone, fine grained, light gray.

156-170, limestone, light gray; sulphur water.

183, limestone, dark gray.

189, limestone, shale, gray.

195 , limestone, dark gray.

205 , limestone, very dark, gray.

210-230, limestone, gray:

235, limestone, black, and limestone, light gray.

240 , limestone, dark gray.

253, limestone, light brown, sandy.

255-260, limestone, gray.

265 , limestone, very dark.

270, limestone, brown.

278,284 , limestone, dark gray.

287, limestone, brown.

288,290 , limestone, gray.

294, 300, limestone, light gray. "Probable base of St. Iouis and top

of Keokuk."

[Warsaw limestone(?):]

305 , limestone, dark gray and white mixed.

310 , limestone, dark gray.

315, limestone, light gray, and flint, white.

325 , limestone, very dark.

330 , limestone, very dark and white, mixed.

340 , limestone, gray, and sand.

348 , limestone, gray.

350 , limestone, gray, fossiliferous.

358-380, limestone, gray. Oil at 363 feet.

400-420, lime shale, hard, gray. 
[Keokuk limestone(?):]

425, limestone, dark gray.

430 , limestones, gray and white, mixed.

435 , limestone, gray and white, limestene shale.

440,445 , limestone and shale, hard, dark.

450 , limestone and shale, gray.

455 , limestones, gray and white, mixed.

460 , limestone shale, hard gray, and sand, white.

465 , limestone, gray, and limestone shale.

470 , limestone, gray and white, mottled.

475 , limestone, gray.

485, limestone, dark gray, white, and limestone shale.

490,495 , limy shale, hard, dark.

501 , limestone shale, hard dark, and sand, white.

506 , limestone, dark gray, and limestone shale, hard.

510 , limestone, light gray.

515 , limestone, gray, and limestone shale.

520-530, limestone shales, hard gray.

[Burlington limestone(?):]

535-665, limestones, very dark, hard, impure, and limestone shales.

[Chattanooga shale:]

670-680, shale, black. Top of Black shale at 670 feet. [Base of

Black shale at 760 feet.]

[Devonian, Silurian, and Ordovician systems:]

685 , limestone shale, very dark.

690 , limestone, brown, impure.

695,700 , limestone, very dark, impure.

705 , limestone, mixed gray and white.

708-760, shale, black. Base of Black shale at 760 feet.

765,770 , limestone, dark brown, sandy.

775, limestones, mixed black and white, and limestones, gray, porous, sandy.

780 , limestone, fine grained, white.

785 , limestone, fine grained, yellow.

790 , limestones, fine grained, yellowish-brown.

$795-875$, limestone, fine grained, white.

880 , limestone, gray and white, mixed.

885-890, limestone, gray.

895,900 , limestone, very light.

910 , limestone, gray.

915-935, limestone, light.

940 , limestone, mottled, red.

945,950 , limestone, gray.

955, limestone, fine grained, light.

960 , limestone, gray.

965,975 , limestones, gray and white, mixed.

980, limestone, light.

985, limestone, gray, and shale.

990, limestone, mottled, gray and white.

995-1,010, limestone, gray.

1,015 , limestone, dark gray.

$1,020,1,025$, limestone, light.

1,030-1,095, limestones, gray, and stales.

$1,100-1,130$, limestone, light.

1,135 , limestone, gray. 
1,140 , limestones, gray and white, mixed.

1,145 , limestone, fine grained, light.

1,150, limestone, light siliceous.

$1,155,1,160$, limestone, light.

1,165 , limestones, light and dark gray, mixed.

$1,170,1,175$, limestone, gray.

$1,180,1,185$, limestone, gray, and shale, dark.

1,190 , limestone, white.

$1,195,1,200$, limestone, gray.

1,205 , limestone, gray, and shale.

1,210 , limestone, gray.

1,215-1,230, limestone, gray, crystalline.

1,235 , limestone, fine grained, gray.

1,240 , limestone, gray.

1,245 , limestones, gray and white.

$1,250-1,260$, limestone, gray.

1,265-1,290, limestone, dark gray.

$1,295-1,305$, limestone, gray.

1,310, limestone shale, hard, dark gray, and limestone, white, mixed.

$1,315,1,320$, limestone, gray and white, mixed.

1,325 , limestone, gray.

1,330-1,375, limestone, dark gray.

$1,380-1,395$, limestone, very dark gray.

$1,400,1,405$, limestone, gray.

1,410 , limestones, dark gray.

1,415, limestone, dark gray, and shale, black. [Top of Trenton.]

1,420 , limestones, dark gray and white, mixed.

1,425 , limestone shale, hard, dark.

1,430-1,440, limestone, gray.

1,445 , limestones, black and white, mixed.

1,450 , limestone, dark gray.

$1,455,1,460$, limestones, gray and white, mixed.

1,465 , limestone, brown.

1,470 , limestone, dark gray.

1,475 , limestone, very dark gray.

1,480 , limestone, gray.

1,490 , limestone, very dark gray.

1,495-1,520, limestones, gray and white, mixed.

1,525-1,550, limestone, dark gray.

1,555 , limestone, gray and white, mixed.

$1,560,1,590$, limestone, dark gray.

1,595 , limestone, gray.

$1,600,1,605$, limestone, light.

$1,610-1,630$, limestone, very dark.

1,635-1,660, limestones, light and dark, mixed.

1,660-1,670, light, limestone, dove-colored. Top of Birdseye.

1685 , limestone, gray.

1,685-1,690, limestone, light.

1,695 , limestone, light mottled.

1,700 , limestone, light.

1,705-1,715, limestones, dark gray and light.

1,720 , limestone, very dark.

$1725,1,730$, limestones, very dark and light, mixed.

1,735 , limestone, black. 
$1,740,1,745$, limestone, very dark, brownish.

1,750 , limestone, black.

1,755 , limestone, very dark, brown.

1,760 , limestone, gray.

1,765 , limestone, dark gray.

1,770 , limestone, very dark.

1,775 , limestone, gray. .

1,780 , limestone, very dark.

The well starts in the St. Louis group and goes down to about the top of the Chazy. The lines between St. Louis and Keokuk and between the Hudson and Trenton can not be drawn with accuracy. The base of the St. Louis is about at 230 . The top of the Black shale is at 670 and its base at 760, giving a thickness of about 430 for Keokuk and 90 for the Black shale. The Black shale is divided in two parts by a bed of dark, impure lime and shales. The top of the Trenton group can be put approximately at 1,415 and the top of the Birdseye at 1,660 .

The record of a still deeper well, on the J. W. Cook farm, on Beaver Dam Creek, near Rhoda, Edmonson County, Ky., just northeast of Warren County, has been furnished by Col. M. W. Crump. The well was drilled in the first half of 1916 and is the deepest one in the southcentral part of the State.

Record of J. W. Cook well No. 1.

\begin{tabular}{|c|c|c|}
\hline & Thickness. & Depth. \\
\hline 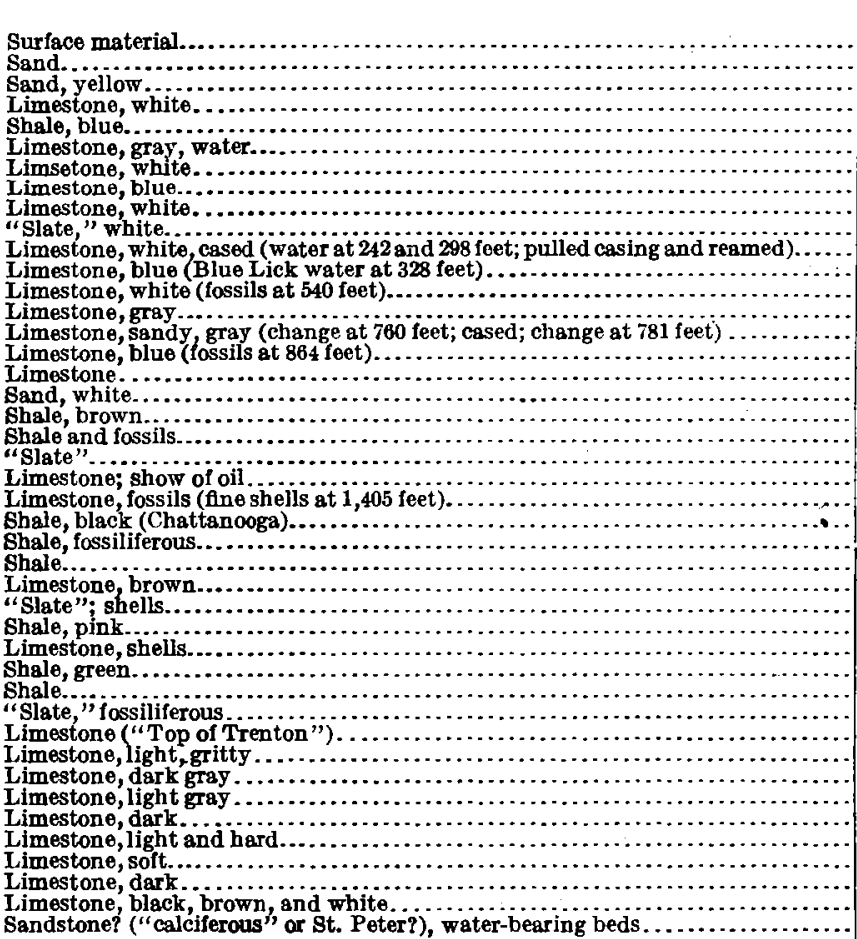 & $\begin{array}{r}\text { Feet. } \\
20 \\
15 \\
50 \\
10 \\
20 \\
15 \\
37 \\
23 \\
8 \\
32 \\
95 \\
18 \\
212 \\
85 \\
160 \\
154 \\
116 \\
137 \\
35 \\
20 \\
28 \\
29 \\
86 \\
78 \\
20 \\
32 \\
18 \\
57 \\
67 \\
6 \\
41 \\
79 \\
316 \\
44 \\
33 \\
33 \\
15 \\
41 \\
187 \\
150 \\
243 \\
275 \\
2 \\
2\end{array}$ & $\begin{array}{r}20 \\
35 \\
85 \\
95 \\
115 \\
130 \\
\mathbf{1 6 7} \\
\mathbf{1 9 0} \\
198 \\
230 \\
325 \\
343 \\
555 \\
640 \\
800 \\
954 \\
1,070 \\
1,207 \\
1,242 \\
1,262 \\
1,290 \\
1,319 \\
1,405 \\
1,483 \\
1,503 \\
1,535 \\
1,553 \\
1,610 \\
1,677 \\
1,683 \\
1,724 \\
1,803 \\
2,119 \\
2,163 \\
2,196 \\
2,229 \\
2,244 \\
2,285 \\
2,472 \\
2,622 \\
2,865 \\
\mathbf{3}, 140 \\
\mathbf{3}, 142\end{array}$ \\
\hline
\end{tabular}


Within Allen County there have been several wells drilled to a depth of 750 feet or more, but most of the available records are too fragmentary or unreliable to be of much value. A well drilled on Long Creek a mile west of Holland, by the Long Creek Oil Co., according to Mr. A. H. Jacobstein, has a total depth of 667 feet. It starts a few feet below the base of the black shale, which outcrops on the adjacent hillside, and probably reaches the rocks commonly know $n$ to the driller as the "Trenton limestone." The incomplete record follows.

Partial record of well No. 1, Long Creek Oil C'o.

\begin{tabular}{|c|c|c|}
\hline & Thickness. & Depth. \\
\hline 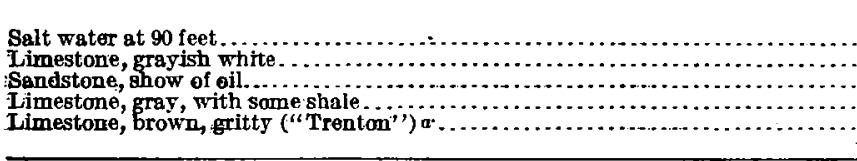 & $\begin{array}{r}\text { Feet. } \\
\mathbf{1 8} \\
\mathbf{1 4} \\
\mathbf{5 0 0} \\
\mathbf{4 5}\end{array}$ & Feet. $\begin{array}{r}90 \\
108 \\
122 \\
622 \\
667\end{array}$ \\
\hline
\end{tabular}

a Probably a limestone just below the so-called "Trenton."

A somewhat deeper hole on Suake Creek, a mile northwest from Mount Union, is known as Cox No. 1. It is adjacent to Forest Springs, and the record is preserved mainly in the form of samples collected at various dopths. From these samples the following log has been compiled:

Record of Cox well No. 1.

\begin{tabular}{|c|c|c|}
\hline & Thickness. & Ixepth. \\
\hline & Feet. & Feet. \\
\hline Iimestone. . . . . . . . . . . . . & 57 & \\
\hline Shale, black & 29 & 86 \\
\hline Sandstone & 9 & 85 \\
\hline Dolomite...... & 27 & 120 \\
\hline 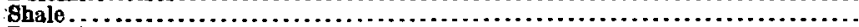 & 6 & 128 \\
\hline 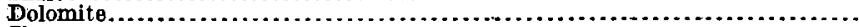 & 42 & 170 \\
\hline 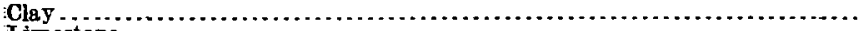 & & 185 \\
\hline 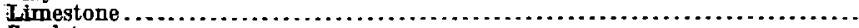 & 2 & 194 \\
\hline 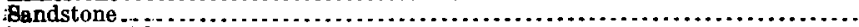 & 16 & 210 \\
\hline Limestone (shaly) & 110 & 320 \\
\hline Timestone, gray..... & 20 & 340 \\
\hline Imestone, shaly & 20 & 380 \\
\hline 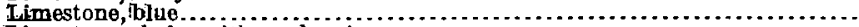 & & 400 \\
\hline 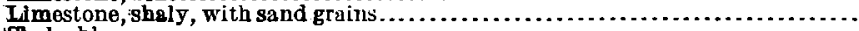 & 20 & 420 \\
\hline 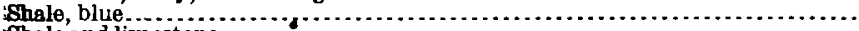 & 20 & 400 \\
\hline 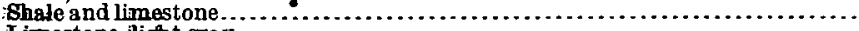 & $\ldots$ & $\mathrm{ten}$ \\
\hline 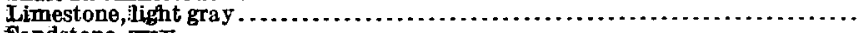 & ............... & 680 \\
\hline 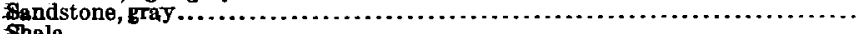 & & 640 \\
\hline Shale & $\cdots \ldots \ldots$ & EHO \\
\hline 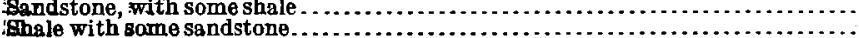 & 40 & $=620$ \\
\hline 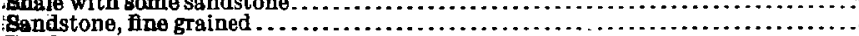 & & 60 \\
\hline Bandstone & & 700 \\
\hline otel depth & & \\
\hline
\end{tabular}

\section{ORDOVICIAX SYSTEM.}

The Ordovician system, which inchades the strata from about 425 to more than 2,000 feet below the surface at Scottsville, consists largely of limestone, most of whioh is probably too compact to serve 
as an oil reservoir. In northern Kentucky the system is exposed throughout an area about 100 miles in diameter, extending from a point near Louisville westward to Flemingsburg and Irrine and from Cincinnati southward to Marion and Lincola counties. It again appears at the surface in middle Tennessee, where the outcrops of the uppermost formations of the system extend northward to a point within 10 miles of the Allen County line. Excellent exposures may be seen along the Jackson Highway between Westmoreland and Gallatin.

Near the bottom of the system is a persistent sandstone which is regarded as equivalent to the extensive and widely known St. Peter sandstone of the upper Mississippi basin, or the "Calciferous" of the southern Appalachian region. Throughout most of its extent the St. Peter yields an abundance of either good fresh water or a less quantity of highly mineralized water but generally not the ordinary salt water of oil fiekds. Blue Lick or sulphur water is commonly reported and shows of oil and gas are found here and there. The St. Peter is believe. to have been reached in deep wells in several of the oil fields of the State. $\Lambda$ t Irvine it is believed to lie about 2, 800 feet below the valley bottoms and in Wayne County it is 1,500 to 1,600 fect below the surface where the Chattanooga shale outcrops. The J. W. Cook well, the log of which is recorded on page 37 of this report and which penetrates to a depth of 1,659 feet below the black shale, probably was stopped nearly or quite at the top of the St. Peter sandstone. No other well in Allen or adjoining counties except the one near the northeast corner of Warron County has approached so deep a horizon.

The so-called "Trenton limestone," which is 600 or 800 feet higher in the section, because of its large supply of oil and gas in Indiana and Ohio has long been considered an Eldorado by the drillers and operators in Kentucky and Tennessee. This formation bas been penetrated in a score of wells in Allen and adjacent counties but has so far failed to yield more than a faint show of oil. It has generally been found to be a hard gritty limestone, too "tight" to serve as a reservoir for oil or gas. The depth of its upper surface below the base of the black Chattanooga shale in various wells is giren in the following table:

Distance from base of Chattanooga shale to top of "Trenton limestone."

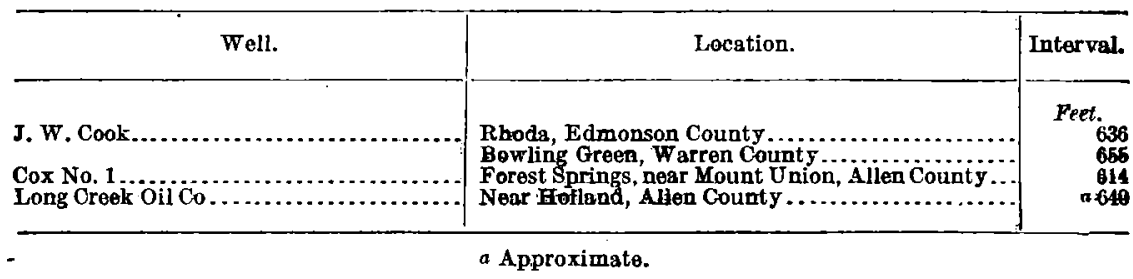


The uppermost beds of Ordovician age exposed near Bransford, 10 miles south of the Allen County line in Sumner County, Tenn., are about 125 feet below the base of the Chattanooga shale. The beds for the first 15 or 20 feet below the cliff-forming Silurian limestones are ordinarily covered by loose dẹbris and soil, which probably indicate the presence of the clay shales that have been designated Mannie clay by Foerste. Farther down the slopes ledges of fairly massive gray limestone are common. These ledges are richly fossiliferous, carrying a profusion of bryozoans, and may represent the Fernvale formation. A collection of fossils from these beds along the west slope of Bledsoe Creek valley immediately above the Jackson Highway, 9.7 miles south of the Kentucky-Tennessee boundary, contains, according to E. O. Ulrich, the following species, which show that the containing beds belong in the Richmond group:

Rhombotrypa quadrata.

Cyphortrypa sp.?

Homotrypa sp.?

Bythotrypa sp.?
Homotrypella?

Undeterminable crinoids.

Streptelasma divaricans.

\section{EXPOSED ROCKS}

ROCKS LYING NEAR THE SURFACE IN THE PRODUCING AREA.

The general nature of the rocks near the surface in the oil-yielding portion of Allen County is illustrated in figures 4 to 9 .

\section{SILURIAN SYSTEM.}

Rocks of Silurian age are exposed along Big Trammel Creek in the extreme southern portion of Allen County, near Barefoot, Tenn. The stream has cut only a few feet into the Silurian rocks, so that their thickness can not be told from this outcrop. Nor can the formation be identified from the drill records. It is not nearly so thick as the Órdovician and may possibly be absent in places.

Near Bransford, at the locality described above, the Silurian rocks are 125 feet thick. They consist of buff or brownish-gray massive, even-bedded sandy limestone. The upper 35 feet of the limestone contains such a high proportion of sand grains that it might almost be called a calcareous sandstone. In the lower 90 feet there are a few beds which carry much sand. Thin partings of blue clay, from 1 to 3 inches thick, were noted here and there at different horizons along the hillside. The formation is much more capable of serving as a reservoir for oil than are any of the subjacent Ordovician strata which have so far been discovered in wells or outcrops in the region.

Both near Bransford and along Trammel Fork the Silurian strata are quite fossiliferous. Favosites (?), a "honeycomb coral," and Pentamerus oblongus, a tongue-shaped "lamp shell," are the most common fossils. The lamp shell occurs in great numbers in the beds 
near Barefoot, which are best exposed in a small ravine tributary to Trammel Fork from the east within 50 yards of the State line, where they immediately underlie the black shale. A more representative collection was obtained from the more extensive exposures along Bledlsoe Creek near Bransford from the same locality as that which furnished the Ordovician fossils listed above. Some fossils were collected from the upper 35 feet of sandy-textured magnesian limestone immediately underlying the black shale, and concerning this collection UTrich reports:

This collection consists of coarsely silicified and otherwise imperfect corals and a few specimens of brachiopods. The former class comprises an undetermined species of Stromatopora, three forms of cup corals (indicating species of Zaphrentis, Cyathophyllum, and probably Omphyma, Favosites favosus, and a Coenites. The brachiopodsare of three species_one specimen of Dalmanella elegantula, three fragmentary valves of a Conchidium cf. C. littoni, and one valve of an apparently new species of Parastrophia allied to $P$. greenii, a Niagaran fossil in Wisconsin.

All things considered, I see no reason to doubt that this lot of fossils came from beds of the age of the Louisville limestone, a late Niagaran formation.

At the same locality the rock 35 to 45 feet below the black shale is less impure limestone and carries a somewhat different fauna. Concerning a collection made at this horizon Ulrich reports:

Though comprising 20 or more specimens only four or possibly five species of fossils are suggested and of these but two are definitely determinable. Fortunately, according to American standards, these two species-Pentamerus oblongus and Atrypa reticularis-when found associated, may be said to establish the age of the containing bed as Niagaran and most probably as late Niagaran (Louisville limestone). Two of the other specimens suggest Stricklandinia but are too imperfect to be more closely identified. There is, besides, an imperfect ventral valve of some species of Camarotoechia, and a coral, showing only in transverse section, of some species of Zaphrentis.

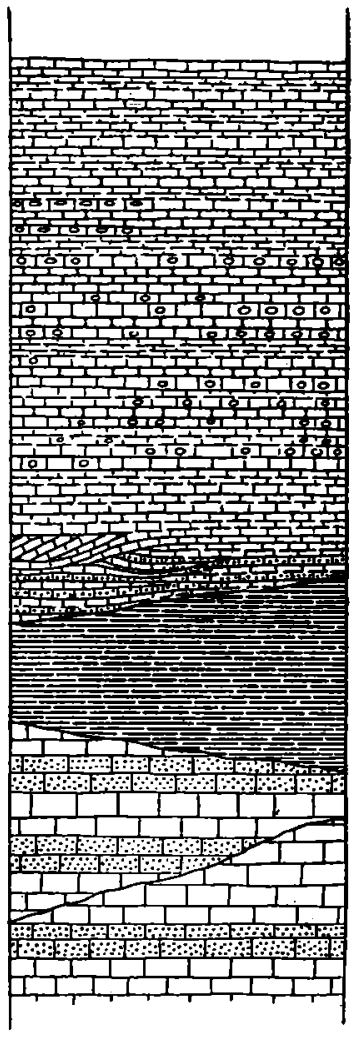

Figure 4.-Generalized section of rocks lying near the surface in the producing area of Allen County, Ky.

This bed seems to immediately underlie the black shale on Trammel Fork at the Kentucky-Tennessee State line, for Ulrich reports as follows on a collection of fossils made here:

The shells in this collection are of Pentamerus oblongus. Evidently the bed is the same as the one from which the preceding collection was taken. This collection is of interest because it gives some idea of the magnitude of the physical break at the base of the Chattanooga shale. Here the Pentamerus bed immediately underlies this early Mississippian shale. At the near-by place where the other collection was made, it lies 35 to 45 feet beneath the Chattanooga. Nothing like such differences 
in the underlying formation obtains in Kentucky localities at which Middle Devonian or even Upper Deronian deposits intervene between the Niagaran limestones and the Chattanooga shale. We infer, then, that most of the erosion of the pre-Chattanoogan land surfaces occurred during and immediately following the Upper Devonian, from which it follows that the Chattanoogan is not of Devonian age but is poetDevonian.

Although it can not be asserted that the Silurian limestone serves as an oil sand in Allen County, the known facts make that inference
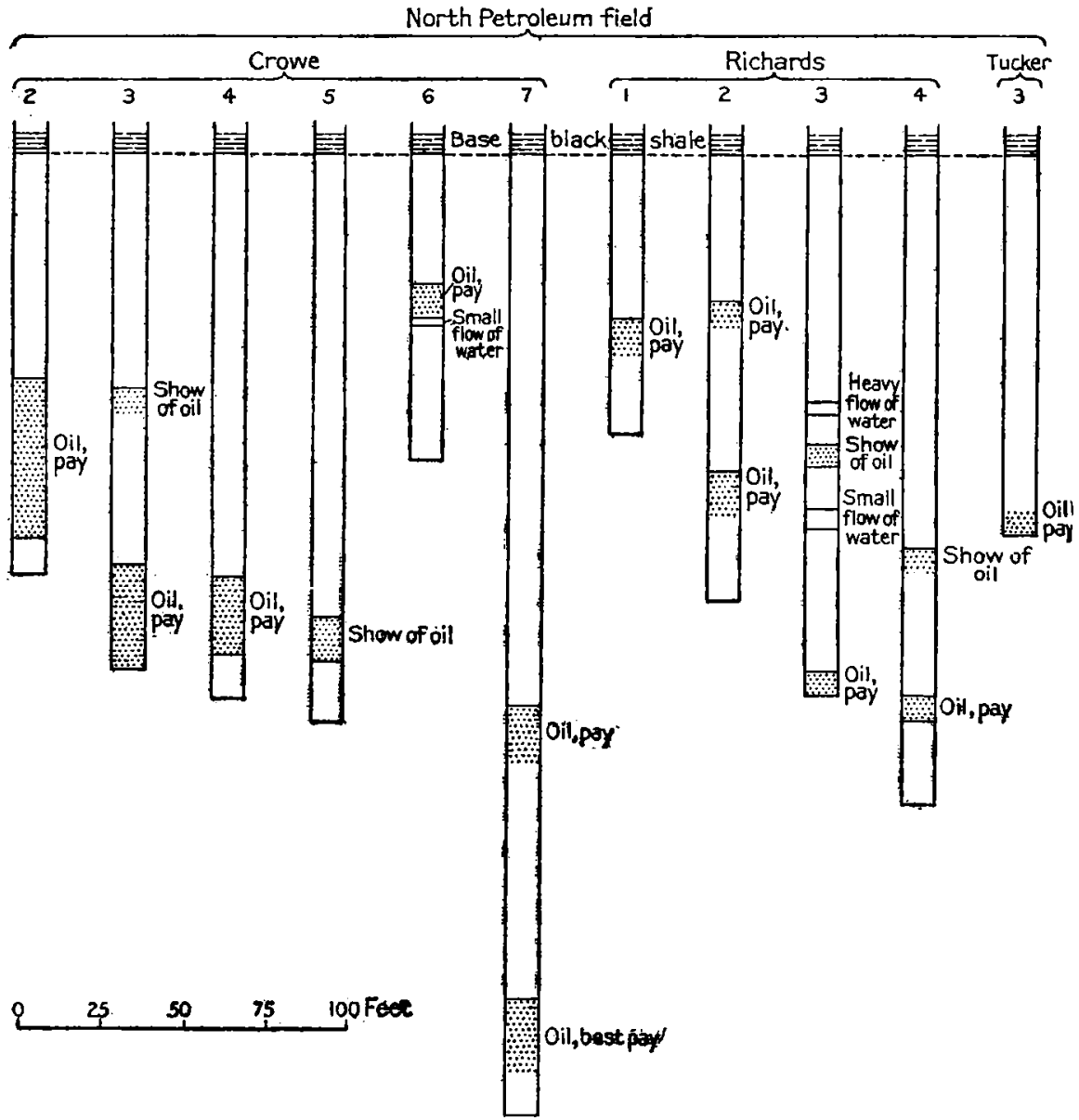

Flgdre 5.-Well sections illustrating character of oil-bearing strata in the North Petroleum oil field.

a very likely one. In both the outcrops described it occupies a stratigraphic position immediately beneath the black shale, which corresponds closely to the occurrence of oil in each of the welldefined pools in the county. Elsewhere, however, the "Corniferous" limestone intervenes. Indeed, in exposures much nearer to the oil fields than those near Barefoot and Bransforl, the "Corniferous" immediately underlies the Chattanooga. It is extremely likely that 
both limestones serve as oil reservoirs in many parts of south-central Kentucky.

In many of the Allen County wells the "pay" is found at a depth of 100 feet or more below the base of the black shale. No definite facts are known concerning the thickness of the "Corniferous" limestone, but its absence from exposures distant only 15 and 5 miles, respectively, from the oil fields suggests that its thickness is not great in those fields. Probably the deeper pay sands in the North Petroleum and Wildwood pools, if not in others, are in the underlying Silurian limestone.

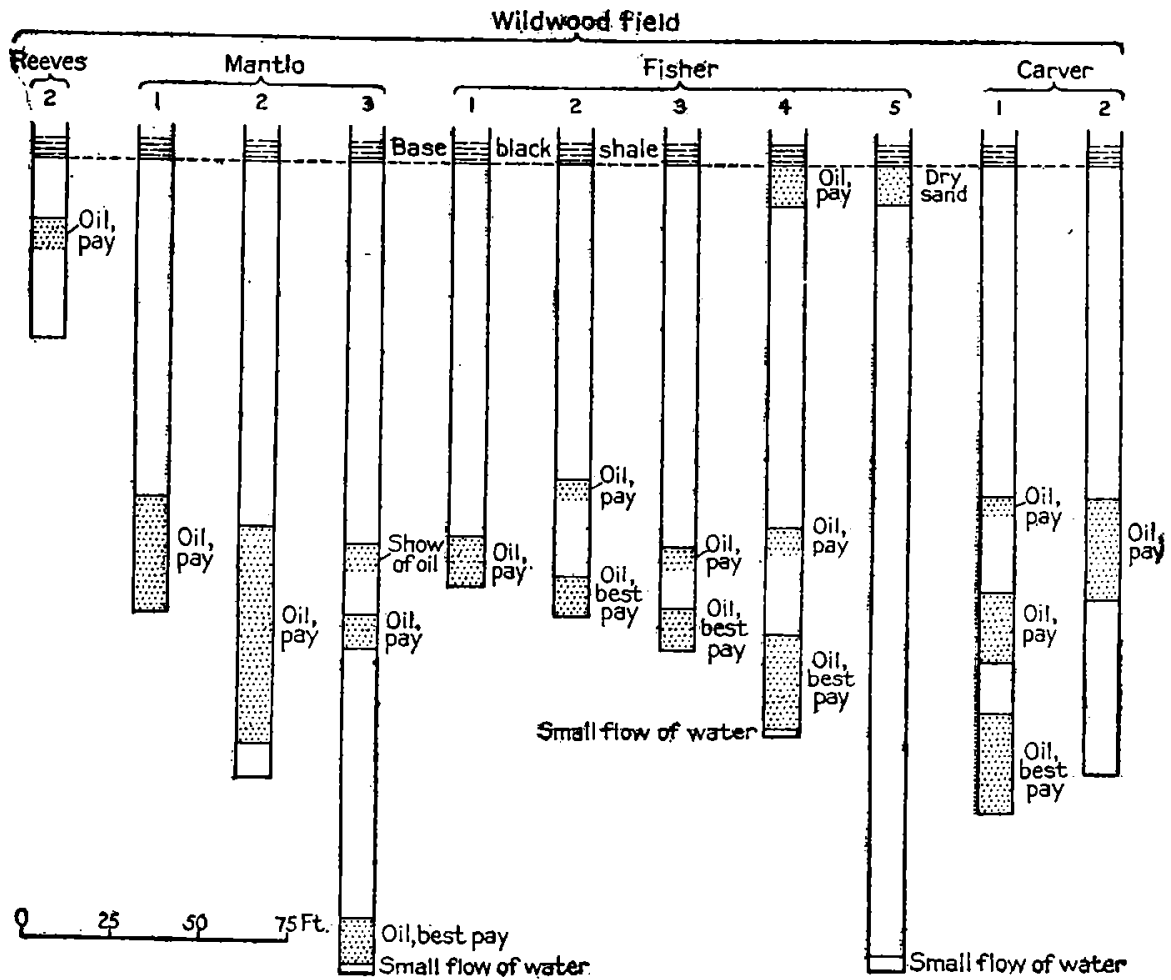

FigUEE 6.-Well sections lllustrating character of oil-bearing strata in the Wildwood field.

\section{DEYONIAN SYSTEM.}

The Devonian system is relatively thin in Kentucky, and several formations present in other areas are not represented here. It consists of two formations-a more or less dolomitic limestone and an overlying black shale, the Chattanooga shale. This shale is the most readily recognized formation of the region, and underlies all of the known or potential oil fields in Allen and adjoining counties. The limestone, widely known as the "Corniferous" limestone, is believed to be one of the "sands" in Allen County, as in most other oil fields of the State. 
Rodeiner field

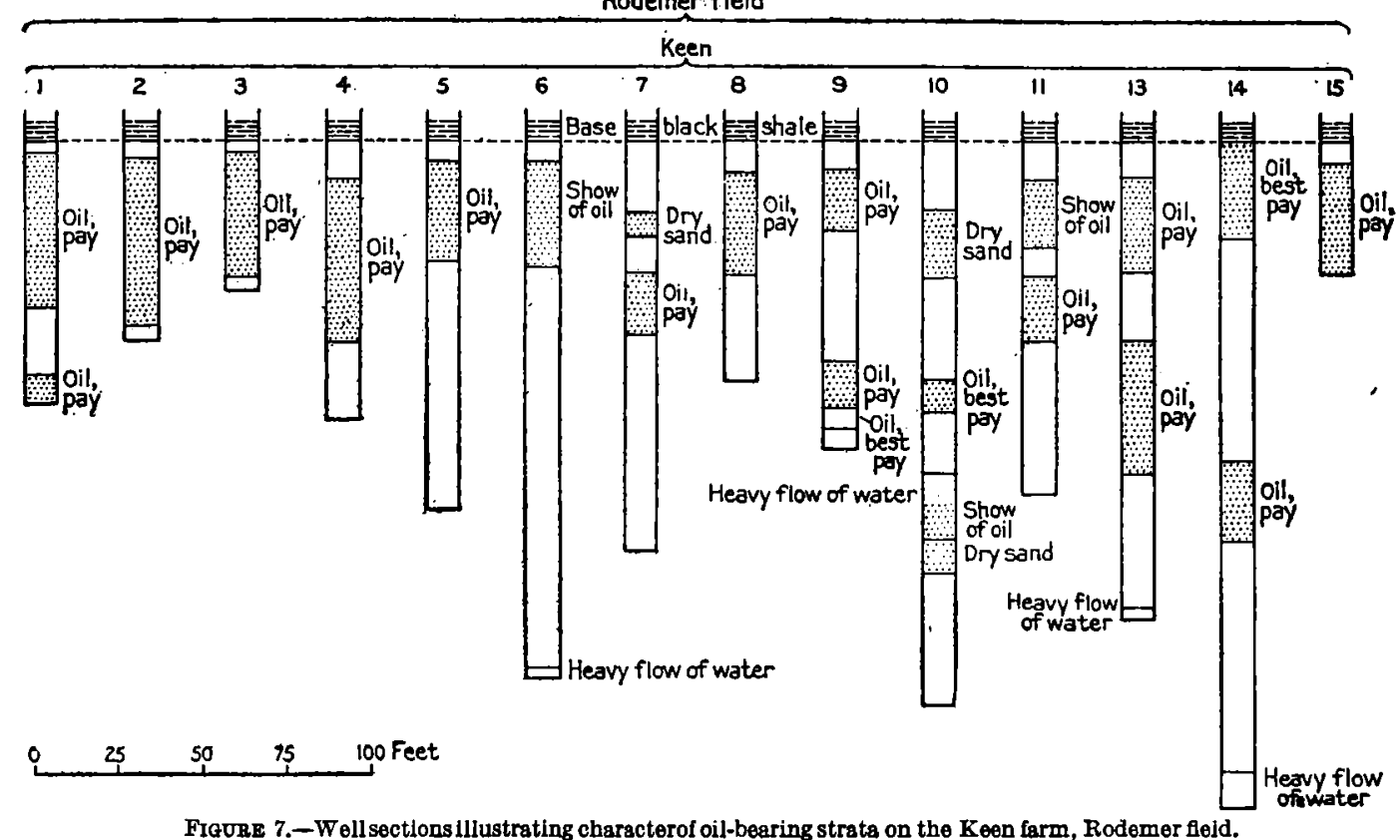

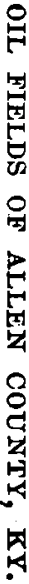

7.-Well sectlons lllustrating characterol oil-bearing strata on the Keen farm, Rodemer fejd. 
Rodemerfield

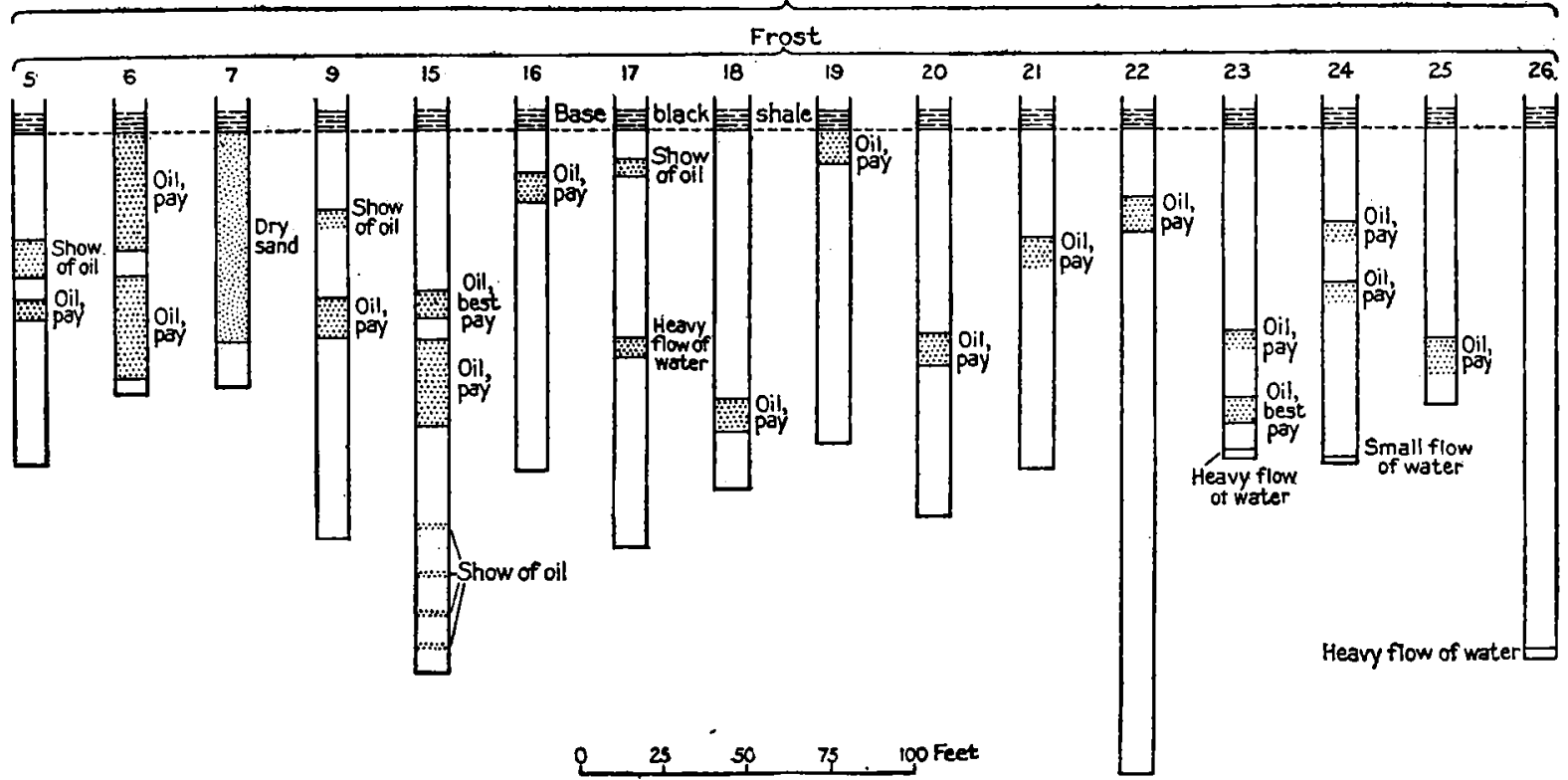

胞

FigURE 8. -Wellsectionsillustrating character of oil-bearing strata on the Frost farm, Rodemer field. 


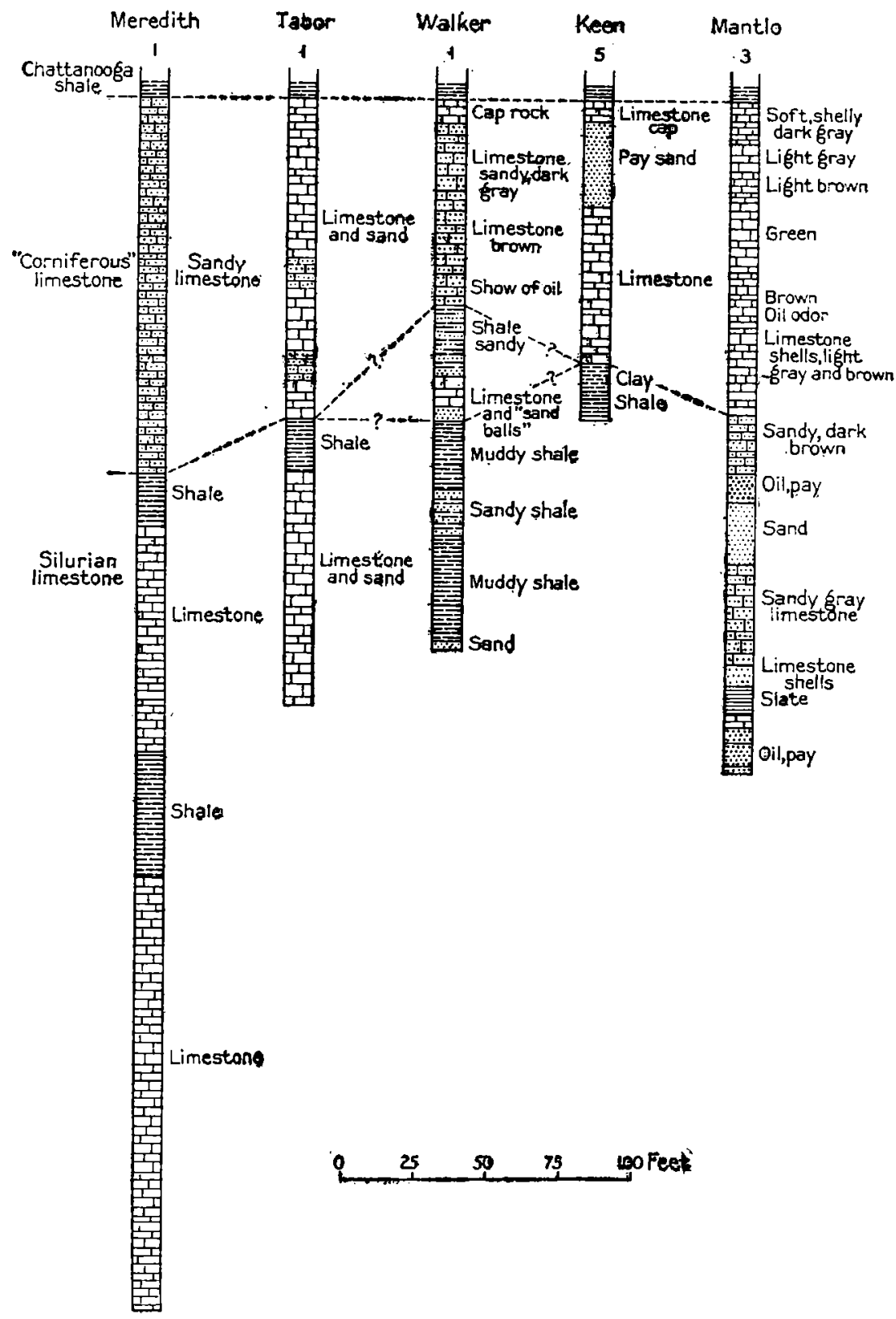

Frgore 9.-Well sections illustrating character of "Corniferous" and Silurian limestones in different wells. 
“CORITFEROUS" LIMESTONE (BOTLE LIMESTONE OF FOERSTE).

Rocks underlying the black (Chattanooga) shale are exposed on Trammel Fork, $4 \frac{1}{2}$ miles south-southwest from the developed oil fields, and on Long Creek and Barren River in the eastern part of Allen County. Fossils are scarce and there is considerable variation in lithologic character among the different exposures, but it is believed that all are referable to a single formation, the "Corniferous" limestone. Indeed, the very scarcity of fossils is perhaps the most characteristic feature of this limestone, and serves most easily to distinguish it from the Silurian limestone, which undoubtedly underlies it and which in places, as noted above, occupies the same stratigraphic position.

The "Corniferous" varies in color from bluish to brownish gray, but weathered surfaces at the outcrops are commonly nearly black. These surfaces display a coarse honeycomb or pitted appearance due to differential solution of the beds. Cavities and extensive caverns are numerous. (See Pl. III.) Large springs issue from this formation on Trammel Fork and Long Creek. The spring water does not taste of oil.

In many exposures, such as those near Holland, the limestone has a porous, somewhat sandy texture. It is rather heavy bedded and is much jointed, so that it weathers out into large blocks, which gradually disintegrate into sandy material before they dissolve. Elsewhere it is a cleaner and more dolomitic limestone with fairly large crystals or more commonly fine grained. At Napier Ford of Long Creek, 3 miles east of Mount Union, an oolitic bed was observed on top of sandy and dolomitic strata that are interbedded and grade into each other. The more porous and sandy zones are well adapted for holding oil, but the greater part of the formation is ordinarily too "tight" to serve as an oil "sand": the rock pores are small though numerous and the total pore space is relatively low.

The thickness of the "Corniferous" limestone is not known and without doubt is variable. Its base has not been observed at any locality in or near Allen County, and it is impossible to determine its lower limit in the well records. Trammel Fork east of Adolphus has cut 12 feet into the "Corniferous" without exposing its base, Long Creek has penetrated it to a depth of 40 feet, and Barren River near Holland cuts 56 feet below its top without exposing subjacent strata.

A few rather poor collections of fossils were obtained from beds believed to belong in the "Corniferous" limestone. One of these collections is from Trammel Fork, $1 \frac{1}{2}$ miles above the mouth of Snake Creek, and Ulrich says that the rock "may be of Niagaran or Middle Deronian or of both ages." An unfossiliferous lithologic col- 
lection was made at Napier Ford, Long Creek, 2.5 miles east of Mount Union, $\mathrm{Ky}$, and Ulrich thus reports upon the specimens:

These specimens of limestone seem to be post-Silurian, and I see no reason to doubt that they were taken from different layers of the peculiar Middle Devonian magnesian limestone that locally underlies the Chattanooga shale in south-central Kentucky.

Another collection was made on Barren River at the mouth of Roatens Creek, 2 feet under the black shale, and Ulrich discusses it as follows:

The collection comprises four small pieces of nearly pure bluish-gray, mainly fine-grained limestone. Two of the pieces contain only columnals of a thick-stemmed crinoid, possibly Dolatocrinus or .Iregistocrinus; the third has a weathered coral suggesting a young IIeliophyllum halli, a very common Middle Devonian fossil; the fourth retains an exfoliated pedicle valve of some terebratuloid brachiopod, possibly Eunella lincklaeni. Of these only the coral is at all diagnostic.

CHATTANOOGA SHALE.

The next formation above the "Corniferous" limestone, or above the Silurian where that limestone is absent, is the Chattanooga shale, a hard black fissile shale from 20 to 80 feet in thickness, well known to drillers because of its peculiar and characteristic appearance. Generally this shale rests immediately upon the limestone below, though in other oil fields, and in parts of the region around Scottsville, a bed of clay shale intervenes. The contact is in general sharply defined, and the surface of the limestone, if the shale were removed, would be described as rough or uneven.

The shale is remarkably uniform in make-up and appearance and is found in almost every well that penetrates to its horizon throughout the broad region of its occurrence, which covers thousands of square miles in the Appalachian and other oil fields. However, in some districts, particularly in western Tennessee, it seems to be lacking.

In some of the wells in Allen and Warren counties the shale is dark brown rather than black; some variation in hardness is also reported, but such differences are relatively slight and small in extent.

In some outcrops, such as those along Trammel Fork above the mouth of Snake Creek, thin lenses of dark, coarsely crystalline, richly bituminous limestone are interbedded with the shale. The largest of these lenses observed in any outcrop was scarcely 6 inches thick and 30 feet long, as exposed in the bank of the creek. It is reported, however, that in the Settle well, in the southern outskirts of Scottsville, a limestone parting 6 feet thick was penetrated in the midst of the black shale.

Outcrops of black shale in Allen County are confined to the southern and eastern parts of the county, where the regional dip of 


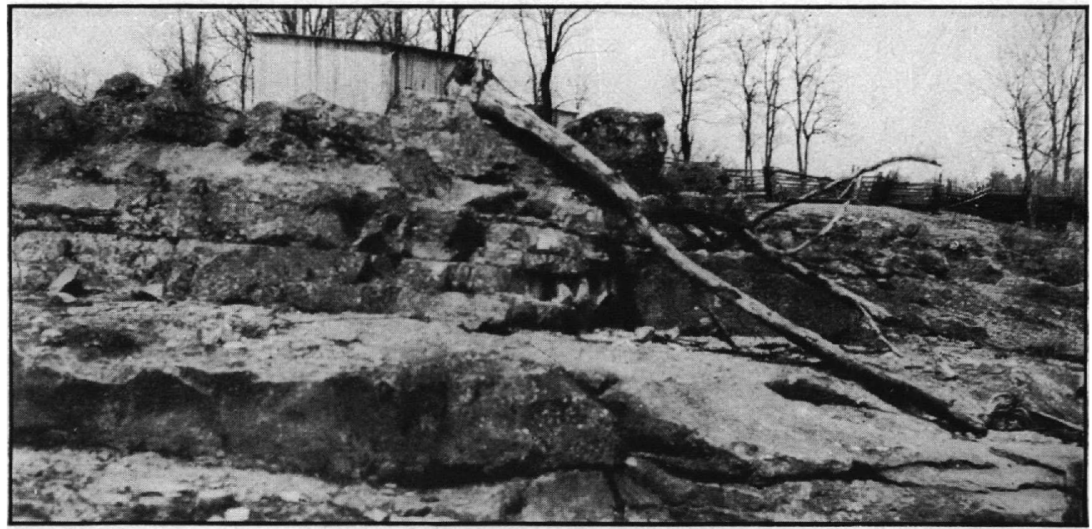

A. EXPOSURE ON BIG TRAMMEL CREEK 61/2 MILES SOUTH OF SCOTTSVILLE, KY.

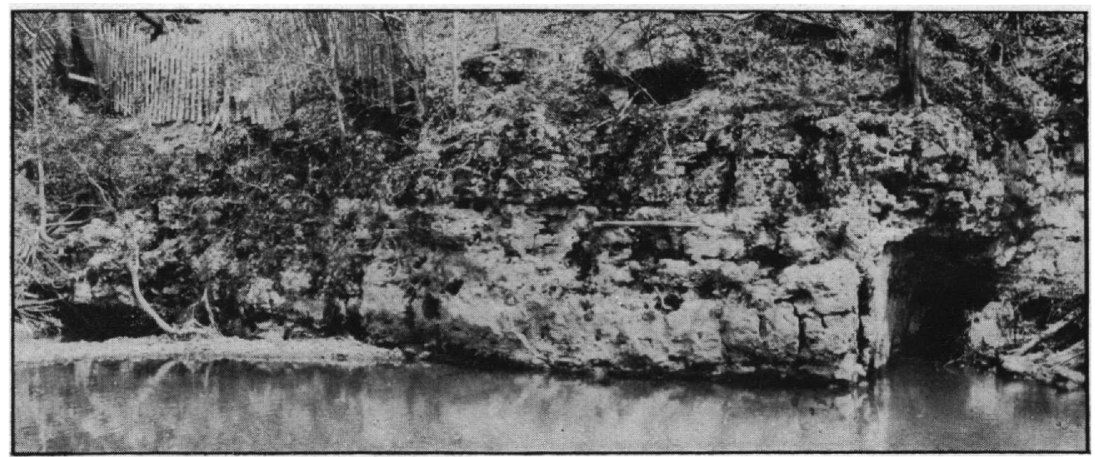

B. EXPOSURE ON LONG CAEEK 1/2 MILES NORTH OF HOLLAND, SHOWING COMMON TENDENCY OF LIMESTONE TO WEATHER TO A DEEPLY PITTED SURFACE.

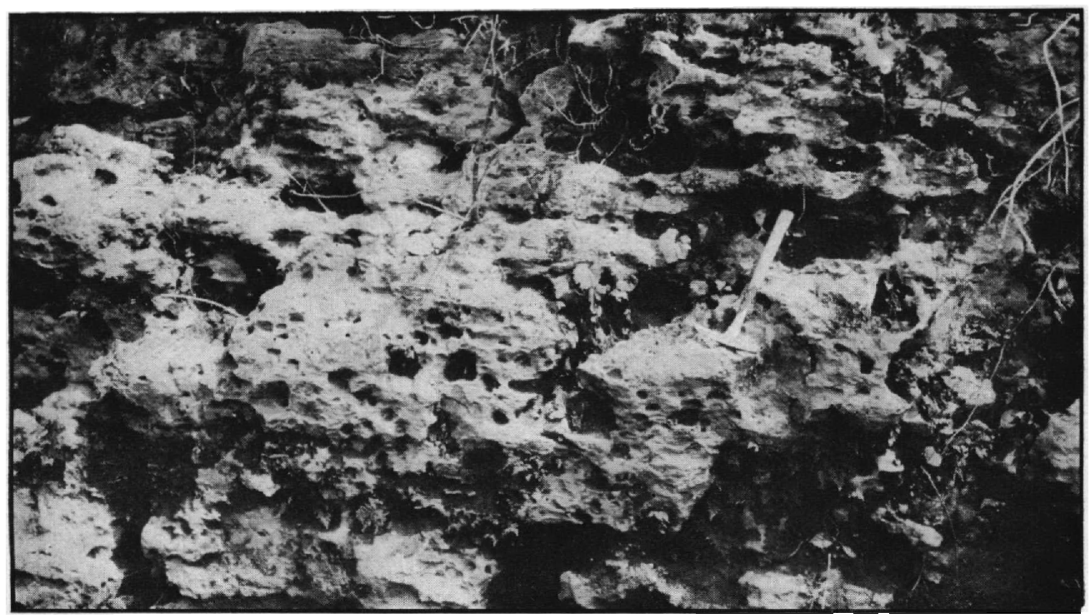

C. DETAII, FHOM LONG CHEEK EXPOSURE SHOWING PITS.

EXPOSURES OF "CORNIFEROUS" IIMESTONE, TIIE OIL "SAND" OF MANY KENTUCKY OIL FIELDS. 

the formations has brought these strata to such an elevation that they have been reached by the large streams. Trammel Fork, Long Creek, and Barren River have cut through the Chattanooga shale to underlying strata.

The thickness of the black shale is somewhat variable but increases with a fair degree of uniformity when traced from the Allen County oil fields toward the northeast, northwest, west, and south. Toward the east it remains fairly constant, so far as the known data indicate, but toward the southeast it becomes notably thinner.

The following table gives a number of the more significant facts concerning thickness. Additional data from wells may be found in the table at the end of this report.

Thickness of black Chattanooga shale at outcrops and in wells in south-central Kentucky.

Allen County, Ky.: $\quad$ Feet.

Long Creek, Napier Ford, 3 miles east of Mount Union....... 37

Cox well No. 1, Snake Creek, 1 mile northwest from Mount Union 29

Trammel Fork, Kentucky-Tennessee boundary............. 27

Trammel Fork, 1 mile above mouth of Snake Creek......... 35

Barren River, east of Holland....................... 40

Long Creek, 2 miles north of Holland................... 45

Myers well No. 1; upland east of Trammel Fork, between Snake and Royal creeks............................... 33

Burd Miller well No. 3, Rough Creek, three-fourths mile above mouth................................. 40

W. H. Miller well No. 2, 400 yards north of Burd Miller No. 3... 45

North Petroleum oil pool......................... 40-45

Rodemer oil pool............................... 38-47

Wildwood oil pool.............................. 42-48

Barlow well No. 1, three-fourths mile south of Scottsville........ 47

Moore well No. 1, 2 miles northeast of Cedar Springs........... 70

Walker well No. 1,2 miles north west of Scottsville ........... 50

T. Tabot well No. 1, 1 mile northeast of Halifax. .......... 46

Tush well No. 1, 1 m miles southwest of Tramnel post office....... 18

Warren County, Ky.:

Teep well at Bowling Green:.................... 00

Miggenbotham well No. 1, 9 miles northwest of Bowling Green.. 107

Robert Hurd well, near Madley, 9 miles west-northwest of Bowl-

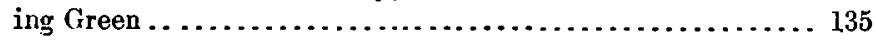

Willey well, Gasper Jiver, 10 miles west of Bowling Green..... 152

Edmonson Cointy, Ky.:

Cook well No. 1, near Rhoda......................... 78

Barren County, Ky.:

Boyd Creek oil pool, $3 \frac{1}{2}$ miles sonth of Glasgor............ 38

Sumner County, Tenn.:

Bledsoe Creek, 11. miles south of $A$ dolphus, Ky............ 53

In Tennessee, southern Kentucky, and adjoining territory, where it is generally 5 to 125 feet thick, this black shale has been named the Chattanooga shale from a typical exposure at Chattanooga, Tenn. In northern Ohio and western Pennsylvania, where in some places $77677^{\circ}-19-B$ Bull. $688-4$ 
this shale is thousands of feet thick and has several distinct subdivisions, it is known as the Ohio shale group. The region of transition from the northern to the southern phase is in northern Kentucky. In southern Indiana and adjacent areas the shale is known as New Albany shale. Some geologists believe that the uppermost part of the Chattanooga belongs in fact with the Carboniferous system. Fossils are so scarce that it is impossible to settle the question. The fossils and lithologic specimens of the black shale found in different parts of Allen County are discussed by Ulrich as follows:

The fossils from the black shale indicate two horizons, one, presumably from the lower part of the shale, possibly of late Devonian but more probably very early Mirsissippian (Cleveland shale) age, the others (all from the upper 10-15 feet) indicating later age (Berea grit and Sunbury shale horizons of the generally accepted Mississippian part of the Chattanooga shale).

The collection from the lower (?) bed of the black shale was obtained by Mather on Trammel Fork in Allen County, Ky. Its principal fossil is a linguloid shell, suggesting the punctate Lingula described by Dr. Girty as Lingulipora williamsana but having much finer punctate that moreover seem to be confined to the inner layer of the shell. It is not the same as the common Lingula of the apper part of the shale, its umbonal ridge being more pronounced and the beak of the pedicle valve more pointed. Possibly it should be called Lingula subspatulata Meek and Worthen, but as authentic examples of that Illinois species are not immediately available for comparison I hesitate to make the identification.

Associated with the Lingula cf. subspatulata are a few very unsatisfactory remains of a nearly smooth calamitoid plant, probably referable to the genus Pseudobornia. Also a few disks of "Sporangites huronensis" and a few conodonts too imperfect to determine accurately.

Two of the higher collections contain fairly good specimens of conodonts, representing species commonly found in Chattanoogan shales. With them are many specimens of Lingula melie and, more rarely, Orbiculoidea newberryi. Both these brachiopods are characteristic of the Sunbury shale in Ohio. One of these collections was obtained in the uppermost part of the Chattanooga black shale, 50 feet above Long Creek, at the crossing of the road from Scottsville to Holland, 7 miles east from Scottsville. The other came from the west side of Long Creek about halfway between Holland and Maynard on east border of Allen County, Ky., and was taken from the Chattanooga ahale 10 feet beneath the top.

Another small collection of Chattanoogan fossils from the area embraced in the Allen County oil field was collected and submitted to me personally by Mr. Wallace Lee, formerly of the Survey but now in private work. This collection is of interest because it differs materially in character of matrix and fossil content from those above reported. The locality is given as "about 3 miles south of Westmoreland, Tenn.," the horizon as " 8 feet beneath the top of Chattanoogs shale." The fossiliferous bed is described as a "thin sheet ( 1 inch to 3 inches) of sandy conglomerate, sparsely fossiliferous." The shale above this "parting is very brittle and hard whereas that below is slightly calcareons, much softer, and flaky, so that in bluff exposures the stiffer upper bed tends to overhang the less resistant lower main mass ( 35 to 45 feet thick) of the shale."

On closer examination the rock prove to be indeed a conglomerate, with quartz pebbles, the largest of which perhaps exceed one-fourth inch in diameter. There are also some phosphatized black clay pebbles, but most of the dark-colored "pebbles" are of organic origin, being more or less beach-wom fossilized bones and teeth of large fishes. One of the teeth is of a species of Cladodrus. 
Besides these larger fish remains, minute conodonts in coneiderable variety are pres ent in both the matrix and some of the clay pebbles. Many of the forms are definitely identifiable with species commonly found in the Cleveland shale in Ohio, in the lower and middle parts of the Chattanooga shale in the Appalachian region, and in the phosphatic basal deposit of the same formation in central Tennessee.

Finally, the material includes more or less imperfect remains of two species of Lingula, one of them evidently the same as $L$. melie, the other a more broadly elliptical species.

According to the physical and fossil evidence before us, the "black shale" in the Allen County oil field appears to correlate with the Chattanooga shale as developed on the west flank of the Nashville dome of the Cincinnati axis in west-central Tennessee, rather than with the basally fuller development of the formation in the Appalachian trough in eastern Kentucky and east Tennessee. I think that the conglomeratic layer may represent a part of the Berea.

Gas and sometimes oil showings in the black shale are often reported, and near Knob Lick, in Metcalfe County, to the northeast of Allen, it is said that oil is being obtained from the black shale in wells. Hoeing ${ }^{1}$ says:

The black shale, wherever tested under cover, carries a large percentage of oil disseminated through it and furnishes the oil for numerous oil springs along its outcrop. When drilled through, it often gives shows of oil and gas all the way through it, especially at points where a hard layer in the shale forms a cap or shell. In other States it has been found to be reservoir for low-pressure gas in moderate quantities, but in Kentucky it has so far, with but one notable exception, given neither gas nor oil in large amounts. The structure of the shale itself is not favorable for the accumulation of oil in reservoirs unless somewhere a sandstone should be found embedded in it.

The exception above referred to is the well-known Meade County field, where gas was found in the black shale and piped to Louisville.

\section{CaRboniferous system.}

MISSISSIPPLAN SERIES.

ROCKS BETWEeN THE BLACK ChatTaNoOga ghale AND THE BT. Lotig Limestone.

General eharacter.

The Mississippian strata below the St. Louis limestone in Allen County are of especial interest to the geologist because Allen County is somewhat centrally located between three regions in which strata of the same age are very different in character. In eastern Kentucky, Ohio, and adjacent territory strata constituting the lower part of the Mississippian series and older than the St. Louis limestone have been called the Waverly group, which has been subdivided into the Logan formation, the Black Hand formation, the Cuyahoga formation, the Sunbury shale, the Berea grit, and the Bedford formation.'

The Berea is a famous oil-bearing bed named from Berea, Ohio, near which it crops out and in places is quarried for grindstones.

1 Hoeing, J. B., The oil and gas sands of Kentucky: Kentucky Geol. Survey Bull. 1, p. 50, 1905.

2 Prosser, C. B., The classification of the Waverly series of central Ohio: Jour. Geology, vol. 9, pp. 214215,1901 . 
In the upper part of the Mississippi basin rocks of approximately equivalent age consist largely of fossiliferous limestone and shale and have been classified from the base upward as the Kinderhook, Burlington, Keokuk, and Warsaw formations. The fauna of these formations has recently been discussed by Weller, ${ }^{1}$ and this part of the section in the vicinity of Louisville and elsewhere has been recently studied and described by Butts. ${ }^{2}$ In Tennessee the rocks underlying the St. Louis limestone and overlying the Chattanooga shale consist chiefly of a cherty limestone which has been called Tullahoma limestone and Fort Payne chert. In the Wayne County oil fields, which are situated between the typical Waverly region and the Tullahoma and Fort Payne region, Munn ${ }^{3}$ describes rocks roughly equivalent under the head of "Waverly" formation. He says that they show considerable variation both in thickness and in character, and consist largely of shale, most of it somewhat claylike and much of it calcareous and fossiliferous. Geodes or crystal-lined nodules or concretions are characteristic of several parts of the formation in Wayne County and also in the Mississippi Valley sections and in Tennessee and some other regions. Most of the oil found in Wayne County occurs in a cherty geode-bearing limestone called by the drillers the Beaver Creek "sand." This limestone lies near the base of the formation but ranges from a few feet to as much as 60 feet above the top of the Chattanooga shale. It is possible that more than one stratum has been identified as the Beaver Creek "sand."

Allen County is thus situated between a region in which the lower part of the Mississippian series is predominantly shale with a little sandstone, a region in which it is characterized by fossiliferous limestones with some shale, and another region in which it is chiefly a very cherty limestone. The section in Allen County, as might be expected, is somewhat transitional between these various types. The rocks in Allen County are fairly fossiliferous, and numerous collections of fossils were made which render it possible to correlate with some degree of accuracy various parts of the section in Allen County with the fossiliferous formations of equivalent age in the upper Mississippi Valley.

These early Mississippian rocks in Allen County comprise three distinct lithologic units, which are not differentiated on the accompanying geologic map because of the absence of an accurate topographic base, as well as because of the reconnaissance nature of the work. They are generally distinguishable in the field, however, and

1 Weller, Stuart, The Mississippian Brachiopoda of the Mississippi Valley basin: Illinois State Geol. Survey Mon. 1, 508 pp., 1914.

Butts, Charles, Geology and mineral resources of Jefferson County, Ky.: Kentucky Geol. Survey, 4th ser., vol. 3, pt. 2, 270 pp., 1915.

s Munn, M. J., Reconnaissence of oil and gas fields in Wayne and MeCreary counties, Ky.: U. S. Geol. Survey Bull. 579, p. 26, 1914. 
are separated one from the other by rather abrupt ehanges in composition. The determination of the position of any locality with respect to these three formations will enable one to know before drilling at what depth the black shale will be encountered at that point, and the black shale is a highly valuable key rock for identifying oil sands and other beds.

Numerous collections of Mississippian fossils were made in Allen County and submitted to G. H. Girty for identification. He furnishes the following discussion of the fossils:

The fossils contained in these collections show several distinct faunas. In the oldest group I would isclude lots $2326,2326 \mathrm{a}, 2335,2340,2341,2344$, and 2330b.

In the third group, which occurs above the last, belong lots $2330,2330 \mathrm{a}, 2331$, and 2336. For reasons to be given later lot 2333 , although it has a different fauna from the others, probably belongs here also.

The fourth and highest group consists of one lot, 2328.

The discussion of the geologic age of these groups can be combined most advantageously with that of their correlation with the section in Jefferson County, Ky., described by Mr. Butts. I may say, however, that I regard the lowest group as of Burlington and Keokuk age. The second group appears to be Warsaw, the third St. Louis, and the fourth Chester (post-Ste. Genevieve) in age.

In the Allen County section a fauna distinctly different from that below is introduced, with lots 2340,2335 , and 2326 , which are said to occur at about the same horizon, and though the lots below agree with the New Providence shale fauna of Jefferson County this clearly represents the Warsaw fauna of that area. In Jefferson County the beds below the Warsaw are divided into four formations, named from below upwards: New Providence shale ( 150 to 160 feet), Kenwood sandstone (40 feet), Rosewood shale (190 feet), and Holtzclaw sandstone (20 feet). Against this total thickness of about 400 feet in Jefferson County stands a thickness of less than 150 feet in Allen County. The fossils from Allen County suggest especially the New Providence fossils of Jefferson County, and it may be significant that the total thickness of beds below the Warsaw in Allen County is almost exactly the thickness of the New Providence shale. On the other hand, the fossils from Allen County appear to have been obtained from the lower 50 feet of these beds, no collections having been made from the 100 feet or less of rocks above them up to the Warsaw horizon. It is quite possible that a general thinning of the sediments occurs southward from Jefferson to Allen County, and that the whole of the thicker section is represented in the thinner. My reason for entering on this discussion, which is perhaps more the domain of stratigraphy than of paleontology, js that the age of the beds in the Allen County section depends upon this correlation. I determined the New Providence shale in Jefferson County as of Burlington age, with the possibility that it contains rocks of Kinderhook age in the lower part, where little or no fossil evidence was obtained. The Kenwood sandstone, Rosewood shale, and Holtzclaw sandstone I referred, on the best evidence available, to the Keokuk epoch. If the entire section in Allen County below the horizon of lots 2326, 2335, and 2340 corresponds to the New Providence shale alone, then I would regard it as of Burlington age, with possibly some Kinderhook, following the Jefferson County determination. But if, as seems more probable, the higher formations of the Jefferson County section are also represented, I must call this part of the Allen County section Keokuk and Burlington, with possibly some Kinderhook. It should be remembered, however, that the sediments in these two areas differ widely from typical Burlington and Kinderhook sediments, and that the faunas show corresponding differences. In other words, no typical Burlington or Keokuk faunas have yet been found in either section. 
With lots 2326, 2335, and 2340, in the Allen County section, is introduced a fauna characterized by Productus magnus, Spirifer washingtonensis, $\boldsymbol{S}$. tenuicostatus, $\boldsymbol{S}$. lateralis, and other forms, a fauna which has recently been determined by Prof. Weller as of Warsaw age, though for a long time it was classed as Keokuk. This determination is quite in accord with evidence seen by me. If this fauna holds its place in the section, these three lots, together with the four others from higher levels already mentioned that have the same facies, must be classed as Warsaw. Some of these lots, however, especially 2326, contain surviving Keokuk types. This same fauna occurs also in Jefferson County, where it has likewise been classed as Warsaw.

A new fauns is introduced in the Allen County section with lots 2336 and 2330a, and the same facies occur more or less distinctly in lots 2330 and 2331 , though lot 2331 differs somewhat from the three others. I am somewhat in doubt whether these collections are Warsaw, Spergen, or St. Louis in age. In this place I may recall that our knowledge of these three faunas is even now.very imperfect and contradictory. No accounts have ever been published of them which are at the same time authoritative and reasonably full. This is perhaps less true of the Spergen fauna than of the two others, but the Spergen is an oolite fauna, and if, as seems to be the fact, oolite faunas in the Chester were contemporaneous with quite different faunas that lived under different environmental conditions, it would be quite logical to expect to find somewhere a nonoolitic fauna that was quite different from the Spergen fauna that we know and yet was contemporaneous with it. Whether such a fauna really exists and what its characters are can not be told. For my own part, I suspect that it does exist and that it has been mistaken for something else. As to the Warsaw and St. Louis faunas, we have a few species from each that are authenic, but we do not know that some of the St. Louis species do not also occur in the Warsaw ar vice versa. We have also lists and other described species (not authentic), but the identifications in the lists may not be accurate and the given horizons of the described species may be erroneous.

The four collections now considered, inasmuch as they come above a Warsaw fauna and present a different facies from it, are presumably post-Warsaw. The only collection that oecurs above them in the Allen County section is lot 2333, which containg only one species, the Lithostrotion basaltiforme of Owen but the $L$. mammilare of Edwards and Haime. This coral is commonly regarded as a guide fossil for the St. Louis limestone of this region, and consequently the age of these four collections must be St. Louis or older. The caral-bearing beds of the St. Louis rarely contain much of a molluscan fauna, so that the faunal change above the horizon of these four collections is far less aignificant than the faunal change below them. It seeme to me, then, that the age of these four collections must be either Spergen or St. Louis. On the whole, I am inclined to regard it as St. Louis (1) because the fauna itself has very little of the Spergen facies; (2) because Mr. Butts found the Spergen limestone to become thinner and to disappear westward, and $I$ do not recall it either to the south or east of Jefferaon County; and (3) because I have collections from Breckinridge County, Ky., that contain the same fauna and that are identified by Butts as St. Louis. Some of the difficulties of the situation are indicated, however, by the fact that the Spergen fauna listed in Butts's Jefferson County report agrees rather closely with the Warsaw fauna of the same report. It contains some supposedly typical Warsaw species, as Spirifer washingtonensis, and, on the other hand, the Waraw fauna of the same report contains some species that have been regarded as typically Spergen. Athyris densa, which is cited by Weller from the Spergen alone, occurs in Butts's Warsaw fauna but not in his Spergen fauna. I have already mentioned that Butte has collected this same fauns (that of lots 2330, 2330a, 2331, and 2336) from rocks supposed to be of St. Louis age in Breckinridge County, but, on the other hand, apparently the same fauna occurs in collections from southern Illinois and from Princeton, Ky., that he calle Warsaw. I am inclined to donbt the correctness of this designation, however, and in the Allen County section, where apparently we have a definite War- 
saw fauna present, I am unwilling to inclucke as Warsaw rocks that overlie and have a different facies. All evidence considered, then, I would refer these four lots to the St. Louis and include with them the Lithostrotion zone described above, -though I recognize that this fauna may prove to be only a different phase of the Spergen fauna.

The remaining lot, No. 2338, is almost certainly not Ste. Genevieve, as was supposed when it was collected, but of later Chester age. As the whole matter of Chester classification and correlation is in dispute, and as the exact horizon represented by this lot is not certain, I will hazard no more definite statement.

Mr. Shaw's Allen County section can be correlated rather definitely with Mr. Munn's Wayne County section. Munn's own collections were small and poor, but I visited the same localities a few years later and made much better ones. I was thus able to correct some minor errors in Munn's earlier work and in my own also. Lithostrotion occurs in abundance in the Wayne County region and makes, I believe, a valuable horizon marker, a fact which would have been useful to Munn if he had known it. The horizon of this fossil (St. Louis) occurs apparently above Munn's Parnell section, ${ }^{1}$ above his Elk Spring Creek section, ${ }^{2}$ at the base of his Monticello Hill section, ${ }^{3}$ and below his Parmleysville section. ${ }^{4}$ At least I do not find this fossil at Parmleysville, and the oldest rocks exposed there, according to my interpretation, are younger than St. Louis. I colleoted the Spirifer washingtonensis fauna (Warsaw) near the top of Munn's Parnell section and also near the top of his Elk Spring Creek section, the Lithostrotion horizon occurring above this fauna at both localities. Thus, I am strongly of the opinion that the upper part of Munn's "Waverly" in the Parnell section correlates with the lower part of his Newman in the Elk Spring Creek section. It was, by the way, on a single species of Spirifer from the upper part of the Elk Spring Creek section that I based my very tentative identification of these beds as Keokuk. Of course I am now satisfied that the age is post-Keokuk, doubtless Warsaw.

The major part of the Wayne County section appears to be unrepresented in Allen County, at least so far as the collection of fossils exhibits it. I would not know where in the Wayne County section to place the only collection made by Mr. Shaw above the St. Louis limestone. I have nothing closely comparable to it from Wayne County, though $I$ do not doubt that its horizon lies above the white oolitic beds that $I$ have identified as Ste. Genevieve.

The following list shows the fossils that have been identified in the collection of Shaw and Mather from Allen County. The collection included also some unidentified crinoids.

Lot $2326(20 \mathrm{~A})$. Warsaw limestone. Lucas quadrangle.

Batostomella sp.

Rhipidomella dubia.

Orthotetes? sp.

Chonetes aff. C. illinoisengis.

Chonetes planumbonus?

Productus magnus var.

Camarotoechia aff. C. mutata.

Dielasma sp.

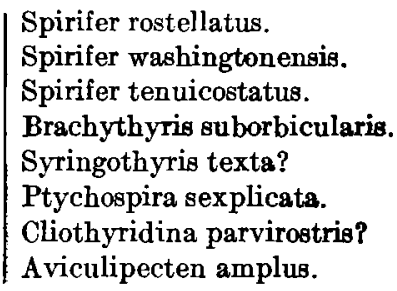

Spirifer rostellatus.

Spirifer washingtonensis.

Spirifer tenuicostatus.

Brachythyris suborbicularis.

Syringothyris texta?

Ptychospira sexplicata.

Cliothyridina parvirostris?

Aviculipecten amplus.

Lot 2326a (20B). Warsaw limestone. Lucas quadrangle.

Triplophyllum sp.

Crinoid.

1 Munn, M. J., Reconnaissance of oil and gas felds in Wayne and MeCreary counties, Ky.: U. S. Ceol.

Survey Bull. 579, p. 26, 1914.

a Idem, p. 29.

3 Idem, p. 30.

Idem, pp. 31-32. 
Lot 2327 (15). New Providence shale, 50 feet above Chattanooga. Adolphus quadrangle.

Sponge spicules.

Zaphrentis cannonensis?

Crinoid fragments.

Brachythyris suborbicularis.

Lot 2328. Chester group younger than the Ste. Genevieve limestone. (Gasper oolite?) Salmon quadrangle.

Triplophyllum spinulosum.

Lithostrotion proliferum?

Pentremites godoni?

Pentremites pyriformis?

Eupachycrinus? sp.

Anisotrypa sp.

Cystodictya sp.

Productus (Diaphragmus?) sp.

Spirifer aff. S. pellensis.

Lot 2329 (12). New Providence shale. Lucas quadrangle.

Zaphrentis cannonensis.

Batostomella? sp.

Leioclema? sp.

Fenestella, several species.

Chainodictyon? sp.

Cystodictya lineata?

Pinnatopora? sp.

Schizophoria poststriatula?

Chonetes shumardianus?

Productus sampsoni?

Spirifer sp.

Delthyris? sp.

Reticularia cooperensis?

Spiriferina sp.

Cliothyridina glenparkensis.

Platyceras sp.

Brachymetopus sp.

Lot 2329a (13). New Providence shale just above 2329. Lucas quadrangle.

Zaphrentis cannonensis?

Cyathaxonia arcuata?

Crinoid stems of large size and great abundance.
Cystodictya lineata?

Schizophoria swallowi.

Athyris lamellosa.

Platyceras sp.

Lot 2330 (44). St. Louis limestone. Lucas quadrangle.

Cladochonus sp.

Pentremites conoideus.

Pentremites conoideus var. perlongus.

Crinoid.

Crinoid.

Spirorbis sp.

Ortonia sp.

Fistulipora sp.

Fenestella, several species.
Polypora sp.

Cystodictya lineata.

Cystodictya pustulosa.

Worthenopora spinosa.

Productus aff. P. setiger.

Dielasma sp.

Spirifer tenuicostatus.

Phillipsia sp.

Lot $2330 \mathrm{a}$ (45). St. Louis limestone. Lucas quadrangle.

Hapsiphyllum calcariforme.

Pentremites conoideus.

Pentremites sp.

Fistulipora sp.

Fenestella sp.

Hemitrypa sp.

Polypora sp.

Dichotrypa sp.

Cystodictya lineata.

Productus aff. P. setiger.

Pustula biseriata.
Pustula indianensis.

Camarotoechia mutata.

Camarotoechia grosvenori.

Dielasma inflatum.

Dielasma sp.

Spirifer tenuicostatus.

Brachythyris subcardiiformis.

Spiriferella $\mathbf{n} . \mathbf{s p}$.

Reticularia setigera.

Cliothyridina hirsuta?

Platyceras sp. 
Lot 2330b (46). Warsaw limestone. Lucas quadrangle.

Rhipidomella dubia.

Spirifer washingtonensis?

Spirifer tenuicostatus.

Spirifer rostellatus.

\author{
Spirifer lateralis. \\ Reticularia setigera. \\ Composita n. sp.? \\ Cliothyridina parvirostris?
}

Lot 2331. St. Louis limestone. Alvaton quadrangle.

Hapsiphyllum calcariforme.

Fenestella sp.

Rhipidomella dubia.
Spirifer bifurcatus.
Brachythyris subcardiiformis?
Reticularia setigera.

Lot 2333. St. Louis limestone. Alvaton quadrangle.

Lithostrotion basaltiforme.

Lot 2334 (18). New Providence shale slightly higher than 2338. Adolphus quadrangle.

Crinoid.

| Crinoid.

Lot 2335 (47). Warsaw limestone. Lucas quadrangle.

Chonetes aff. C. illinoisensis.

Productus magnus.

Spirifer aff. S. littoni.

Spiriferella neglecta?

Lot 2336. St. Louis limestone. Alvaton quadrangle.

Cyathaxonia venustum?

Cladochonus ap.

Ortonia sp.

Batostomella sp.

Fenestella, several species.

\author{
Hemitrypa sp. \\ Polypora sp. \\ Phractopora? sp. \\ Cystodictya lineata. \\ Cliothyridina sublamellosa.
}

Lot 2337 (34). New Providence shale, lower 30 feet. Adolphus quadrangle.

Zaphrentis cannonensis?

Crinoid stems of great size and of great abundance.

Crinoid.

Crinoid.

Schizophoria swallowi.

Spirifer montgomeryensis?

Cyrtia? (Spiriferella?) n. sp.

Brachythyris suborbicularis.

Cliothyridina n. sp.?

Lot 2338 (16). New Providence shale, slightly below 2334. Adolphus quadrangle.

Spirifer montgomeryensis?

I Cliothyridina obmaxima.

Lot 2339 (16). New Providence shale. Adolphus quadrangle.

Cladochonus sp.

Crinoid.

Crinoid stems of great size and abundance.

Lot 2340 (17). Warsaw limestone. Lucas quadrangle.

Stenopora? sp.

Cystodictya? sp.

Rhipidomella dubia.

Productus magnus var.

Pustula aff. P. indianengis.

Pustula sp.
Spirifer washingtonensis.

Spirifer lateralis.

Spiriferina sp.

Cliothyridina? sp.

Eumetria vera.

Platyceras. 
Lot 2341. Warsaw limestone. Alvaton quadrangle.

Rhipidomella dubia.

Orthotetes? sp.

Spirifer aff. S. littoni.

Spirifer lateralis.

Lot 2244 (58). Warsaw limestone. Alvaton quadrangle.

Rhipidomella dubia.

Productus magnus.

Spirifer keokuk.

Spirifer lateralis.

Now Proridence shale.

The lower 40 to 50 feet of Mississippian rocks overlying the Chattanooga shale consists of shale and shaly limestone with a predominantly bluish-green tinge. The formation is thin-bedded in most localities, the more calcareous strata having a maximum thickness of 10 inches, but in places very massive limestone has been observed. Geodes are common, but chert is not abundant. Many of the bels are composed of fragments of crinoid stems rather loosely cemented by calcareous greenish-gray mud or sand. The lithologic character of these rocks is not constant, but nearly everywhere it may be recognized by its abundance of crinoid stems and its green color. The chert is scattered throughout a few bands and as a rule is not aggregated into slabs or concretions as it is in the overlying formations. These rocks are roughly equivalent to the Burlington limestone but may include some beds of Kinderhook and basal Keokuk age, and they no doubt represent the New Providence shale.

The shaly beds are easily weathered, and there is a strong tendency for the more resistant beds to slump down over the shaly ones or over the underlying black shale where it is exposed. Consequently, good exposures are not abundant. The best outcrops noted are those along Walnut Creek, north of Maynard, along Long Creek and Barren River northwest and northeast of Holland, and in the railroad cuts south of Petroleum. In none of these exposures does the New Providence depart far from 40 feet in thickness.

A characteristic feature of the New Providence shale and one which is likely to be a source of error in studies of geologic structure unless it is clearly understood is the cross-bedding, which is commonly present. False bedding or cross-bedding may be observed on a small scale at most outcrops, but in the railroad cuts 1 or 2 miles south of Petroleum it is developed on a truly remarkable scale. Plate IV gives some idea of the development of this phenomenon there. Beds which apparently dip as high as $10^{\circ}$ cut across the edges of horizontal beds and are in turn beveled and overlain by strata in an approximately horizontal position. So persistent are some of these false dips and so extensive are the planes of contact between tilted and horizontal strata that the temptation is strong to interpret them as representing angular unconformity following diastrophic disturbance in early Mississippian time. This interpretation, however, would be 


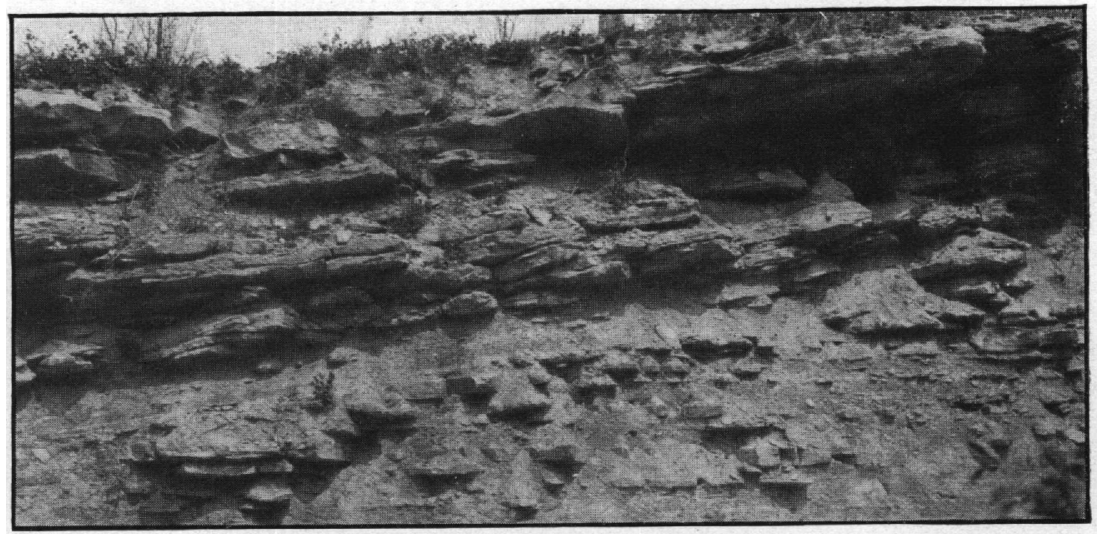

A.

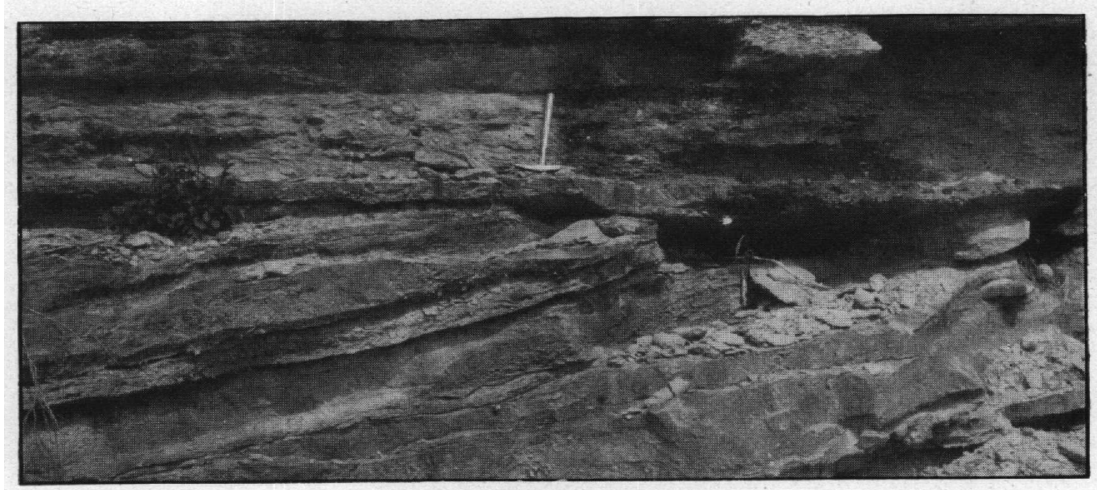

B.

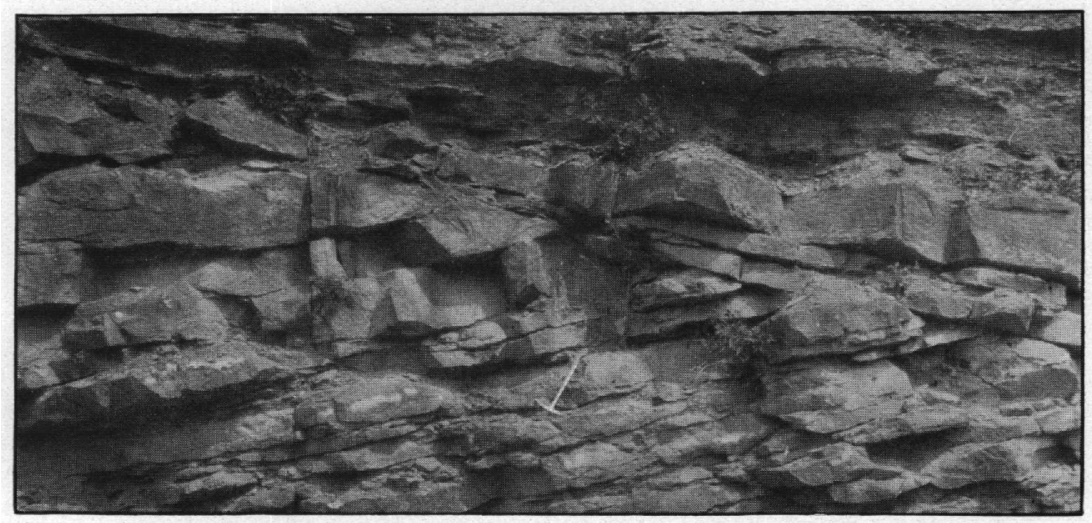

$c$.

ORIGINAL STRUCTURAL FEATURES OF LITTLE OR NO VALUE IN OIL AND GaS FINDING, EXPOSED IN RAILWAY CUT 1 MILE SOUTH OF PETROLEUM, KY.

The views show cross-bedding on a large scale and strong unconformities resulting almost certainly from submarine erosion. The attitude of other strata in the vicinity shows that the lower beds have not heen tilted but are approximately in the attitude in which they were
deposited. In $C$ note thickening of upper beds away from unconformity. 

erroneous. Tilted beds rest on approximately horizontal ones, as illustrated in Plate IV, and are clearly the result of deposition upon an uneven surface, filling a submarine channel previously or contemporaneously excavated by ocean currents. Individual beds thicken from less than an inch to more than 5 inches when traced dewnward toward the bottom of the trough. In one locality, a shallow basin, 3 feet deep and 30 or 40 feet in diameter, which is excavated in gently dipping strata, is filled by beds that dip toward its center and thicken notably from the margins toward the middle; these beds are in turn beveled above and overlain by horizontal strata.

There are at least four angular unconformities in these exposures, all within a formation 50 feet thick.

The New Providence, in spite of its high content of lime, is a truly clastic formation - that is, it is composed of fragments accumulated under the influence of waves and currents. Its fossils were broken and dashed to pieces, the crinoid heads were disintegrated, the brachiopod valves were torn asunder, and the horn corals were scratched and worn before they found a resting place in the calcareous muds and silts of the ocean floor. The activity of waves and currents is also attested by the sudden variations between superjacent beds, the thickening and thinning of individual strata, and the false or cross bedding which occurs on all scales from small to great.

If the horizontal beds that are illustrated in Plate IV, $B$, were covered and only the tilted ones were exposed, a strong dip in the formations at that point might be inferred. So persistent is this feature in the basal portion of the Mississippian of Allen County that no directly observed "dip" in those rocks may be safely recorded as indicative of structural deformation affecting the oil-bearing strata.

In addition to the ubiquitous crinoid stems, a species of horn coral, Zaphrentis cannonensis, and a large, thick-shelled Spirifer seem to be characteristic fossils of this member.

The New Providence occupies the same stratigraphic position in Allen County as that occupied by the beds that contain the Beaver Creek "sand" in Wayne County, 60 miles to the east. Certain of its more siliceous and geodiferous beds are well adapted to serve as reservoirs for oil and gas. Throughout the southeastern half of Allen County the formation is so dissected by erosion that any oil which it might have contained in past ages has long since been dissipated. In the northwestern half of the county, on the other hand, this formation is below the present valley bottoms and may contain oil pools. The strong show of oil in the Cal Guy well No. 2 on Trammel Fork, 7 miles west from Scottsville, is from the "sand" believed to represent the Beaver Creek "sand" of Wayne County. Shows of oil

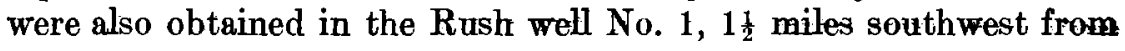


Trammel post office, from a 4-foot "sand" 72 feet above the black shale, but this "sand" is probably not in the New Providence shale unless that formation thickens abruptly toward the west. In the Stamps well

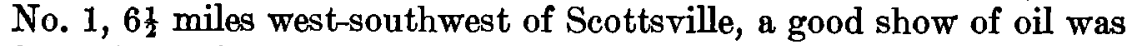
found in a 2-foot "sand" $2 \frac{1}{2}$ feet above the black shale. According to Safford," the oil "sand" in the Porter well, near the junction of the east and west branches of Bays Forks, was tapped at the depth of 55 feet. This figure is probably far more accurate than the traditional reports of a depth of 300 feet or even more, as Prof. Safford visited the well within a year after it was drilled and wrote his account immediately after his visit. The oil reservoir must therefore have been above the black shale and within 100 feet of its top. More than likely it was in the New Providence and represents again the position of the Beaver Creek "sand."

\section{Fort Payne chert.}

Several of the writers whose papers are summarized in the bibliography on pages 8-15 refer to the entire series of beds between the black Chattanooga shale and the St. Louis limestone as the Keokuk formation. As a matter of fact less than half of these strata can properly be correlated with the Keokuk limestone.

About 40 feet above the black shale there is generally a wellmarked change in the lithologic character of the strata, although there is no recognizable break of stratigraphic series at this horizon. Light-buff or brown shaly limestones overlie the green-tinged shales or impure limestones of the basal formation of the Mississippian, the New Providence shale. These limestones are interbedded locally with strata 6 to 12 inches thick, of pure pinkish-gray, coarsely crystalline limestones. Geodes and chert are less abundant than in the underlying beds. A few feet higher in the section the coarsely crystalline beds of pure limestone become dominant, and the brown shaly limestones occur only as partings between the more massive pink or green tinged, gray beds. Some of these massive beds contain sheets of chert, which increase in amount in the higher beds until at a height of 75 or 80 feet above the black shale the beds are characterized by numerous sheets, 3 or 4 inches thick, of light-brown or milky-white chert, which weather out in the form of flat slabs or blocks. Throughout a thickness of 50 or 60 feet the strata consist of thin-bedded buff or brownish-gray limestones that carry numerous geodes and contain an abundance of chert in sheets or plates. This entire series of beds, from about 50 to about 150 feet above the black shale, is referred to the Fort Payne chert.

Outcrops of this formation are common along the slopes of nearly every valley in the central and eastern parts of the county. Excel-

1 Safford, J. M., Note on the geologic position of petroleum reservoirs in southern Kentucky and in Tennessee: Am. Jour. Sci., 2d ser., vol 42, pp. 104-107, 1866. 


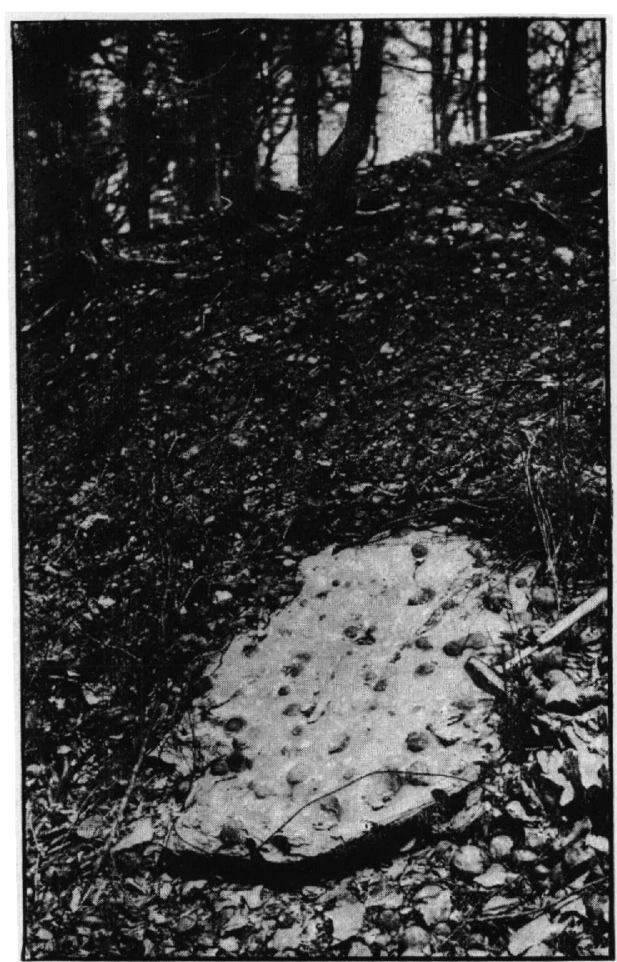

A. GEODES WEATHERING OUT OF WARSAW LIMESTONE NEAR HALFWAY, ON SCOTTSVILLE-BOWLING GREEN PIKE, ALLEN COUNTY, KY.

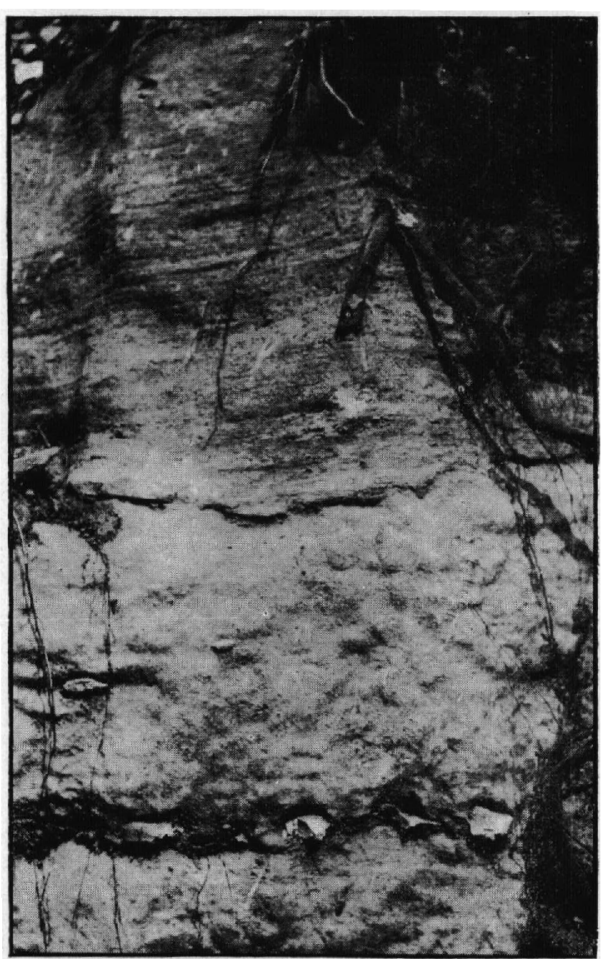

B. LOCAL UNCONFORMITY IN ST. LOUIS LIMESTONE (p) ON SCOTTSVILLE-BOWLING GREEN PIKE ABOUT 15 MILES WEST OF SCOTTSVILLE, KY.

Above the unconformity is very pure oolitic crossbedded limestone, below is cherty limestone. 

lent exposures may be seen on Walnut Creek north of Maynard, on Trammel Fork near the crossing of the Franklin pike, and on both branches of Bays Fork near Scottsville.

Fossils are not so abundant in this formation as in the underlying and overlying beds. Certain of the more geodiferous or more sandy beds in the formation are fairly porous or open and might under favorable conditions serve as reservoirs of oil and gas. It is very likely that the show of light oil in the Rush well (p. 109) was derived from this formation.

\section{Warsaw limestone.}

The Warsaw limestone overlies the Fort Payne chert in apparent conformity and comprises about 100 feet of limestone and shale. It is thin bedded, ranges from gray or bluish gray to lemon-yellow, and weathers to a brick-red cherty soil, which mantles the hillsides beneath the St. Louis formation.

Immediately overlying the cherty limestones of the Fort Payne are thin-bedded argillaceous limestones which contain great numbers of shells of Spirifer washingtonensis and Productus magnus with many crinoid stems and other brachiopods. Shaly limestones predominate throughout the lower 20 feet of the Warsaw in most localities, but beds of gray, coarsely crystalline limestone, 6 inches or more in thickness, composed almost exclusively of crinoid stems with a few spirifers or horn corals, are present at different levels. The greater part of the formation, however, consists of bluish-gray thin-bedded cherty limestone, containing many geodes, which breaks with a conchoidal fracture and is fairly easily recognized because of its color. Under certain conditions it weathers to a yellowish-brown or brick-red soil crowded with geodes 2 or 3 inches in diameter and containing many nodules or blocks of chert. (See Pl. V, A.)

Outcrops of this formation are abundant along Trammel Fork and Bays Fork in the central and western portion of the county. The localities noted in connection with the lists of fossils are typical.

\section{Spergen (?) limestone.}

Whether or not any beds of Spergen age are present in Allen County has not yet been determined. The evidence is discussed by Girty in his report on the fossils. The portion of the section which may belong to this formation consists of purer and heavier bedded limestone than the underlying Warsaw. This limestone, however, is here included in the St. Louis limestone.

\section{ST. LOUIS LIMESTONE.}

The St. Louis limestone differs from those underlying it in that the beds are more massive and contain only a little shale and fewer fossils. It seems to dissolve in rain water charged with organic acids from the soil more readily than the underlying limestone, and hence out. 
crops are not abundant. Perhaps this is due to a lower percentage of chert, perhaps to greater fracturing because of its more massive character, and perhaps to its more porous character. The area underlain by the St. Louis beds may, however, be easily recognized by its great number of deep steep-sided sink holes (see Pl. VI, $B$ and $C)$ and its ordinarily bright-red soil which contains many rounded nodules of dense structureless chert.

The main area of its outcrop is in the western half of the county. The base is barely exposed in the deepest valleys along the northwestern border of the county, and to the southeast it gradually rises until its base is nearer the tops of the divides in a belt that extends northeast and southwest through the central part of the county. Typical topography and soil resulting from the disintegration and solution of the St. Louis formation are well developed 1 to 3 miles south of Gainesville, between Halfway and Allen Springs, and northwest of Pope.

The upper limits of the St. Louis formation have not been observed in Allen County, but in the vicinity of Bowling Green it is about 300 feet thick. The only common fossil is a species of colonial coral that is often identified as Lithostrotion canadense but frequently called a petrified hornet's nest. A typical lithologic feature is shown on Plate V, $B$.

STE. GENEVIEVE LIMESTONE.

The Ste. Genevieve limestone does not occur in Allen County but underlies a great area to the northwest, including a large part of Warren County. Indeed its outcrop, 10 or 20 miles in width, extends east-northeast to Hart County and then northward to Hardin, along both sides of the Louisville \& Nashville Railroad, westward from Warren County through Logan and Todd counties and farther west. It is named from Ste. Genevieve, Mo., where it is a fossiliferous oolite, and its principal interest to oil men lies in the fact that it carries oil in the southeastern Illinois field, where it is known as the McClosky sand. It is generally a very pure limestone, consisting of more than 99 per cent calcium carbonate, and weathers into a characteristic mass of large blocks with rounded edges. In many places, particularly around Bowling Green, it is characterized by broad, shallow sink holes. (See Pl. V, A.) A generalized section of the Ste. Genevieve and overlying rocks exposed in the northwest half of Warren County has been made up by Butts, ${ }^{1}$ who furnishes it for this report. His subdivisions of the Chester group are more fully described and defined in a recent report. ${ }^{2}$ Whether the Ste. Genevieve should be included in the Chester group or excluded from it is a question still in dispute.

\footnotetext{
1 Butts, Charles, unpublished report.

- Butts, Charkes, Descriptions and carrelation of the Mississippian formations of western Kentucky, pp. 62-116, Keatueky Geol. Survey, 1917.
} 


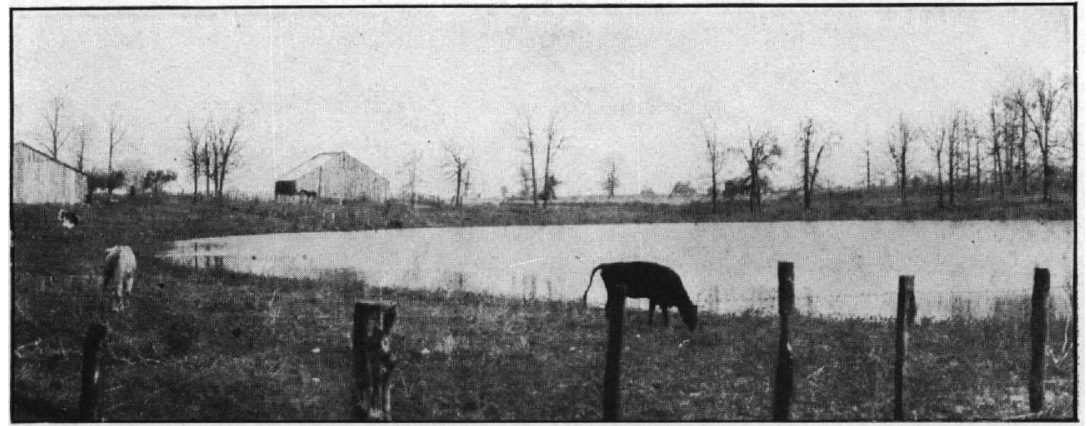

A. BHOAD, SHALLOW UNDRAINED SINK HOLE CHARACTERISTIC OF SURFACE UNDERLAIN BY STE. GENEVIEVE LIMESTONE, SCOTTSVILLE-BOWLING GREEN PIKE 2 MILES EAST OF BOWLING GREEN, KY.

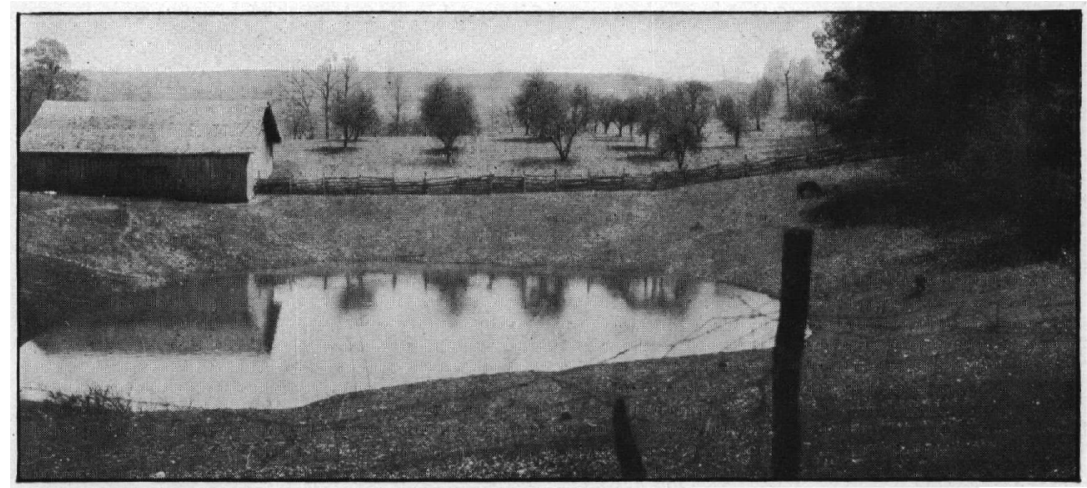

B. DEEP, STEEP-SIDED UNDRAINED SINK IIOLE CHARACTERISTIC OF SURFACE UNDERLAIN BY ST. LOUIS LIMESTONE, SCOTTSVIILE-BOWLING GREEN PIKE 11 MILES WEST OF SCOTTSVILLE, KY.

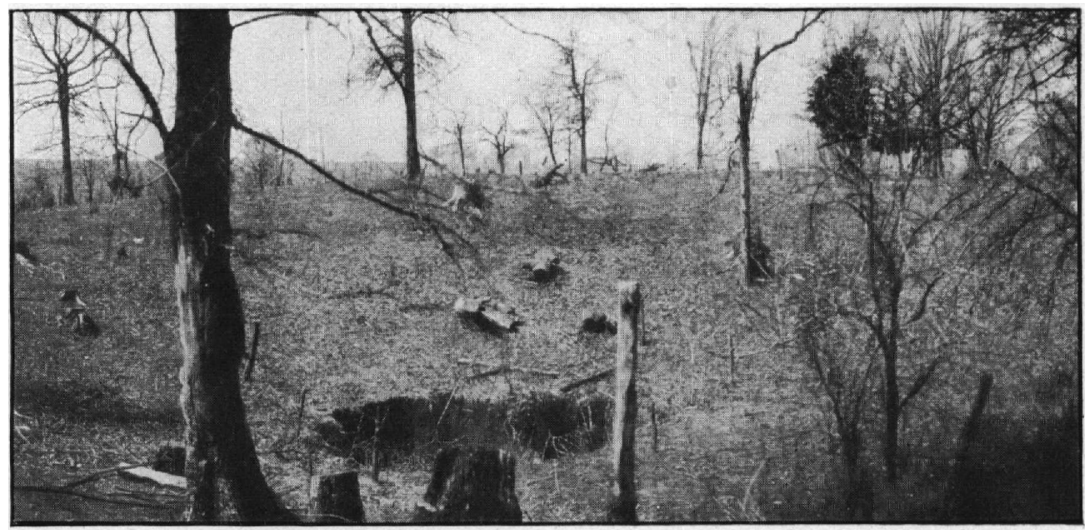

C. OPEN-THROATED SINK HOLE IN ST. LOUIS LIMESTONE ON SCOTTSVILLEBOWLING GREEN PIKE 8 MILES WEST OF SCOTTSVILLE, KY.

SINK IIOLES OF THREE KINDS. 

Generalized section of rocks exposed in the northwest part of Warren County, Ky., between Bowling Green and Riverside.

Carboniferous system:

Pennsylvanian series (128 feet):

Pottsville fórmation (128 feet):

Feet.

Sandstone.................................. 10

Not exposed..................................... 27

Shale.................................... 88

Conglomerate, coarse........................ 3

Mississippian series ( 675 feet):

Chester group (in whole or in part):

Buffalo Wallow formation (129 feet):

Shale, mainly soft bluish and greeniah, with limestone beds.

Not exposed............................ 40

Limestone............................. 20

Shale................................. 40

Tar Springs sandstone:

Sandstone, shaly ....................... 50

Glen Dean limestone:

Limestone, medium, thick bedded, bluish........ 50

Hardinsburg sandstone:

Sandstone, shaly.

Golconda formation:

Limestone, with apparently a layer of sandstone 5 to 10 feet thick near the middle; upper limestone medium thick bedded; lower coarse and oolitic..

Unconformity (?).

Cypress sandstone:

Sandstone, thin to thick bedded..............

Unconformity (?).

Gasper oolite (91 feet):

Limestone, in part oolitic; contains Martinias and other fossils near the top................. 40

Shale.............................. 1

Limestone, upper part oolitic, lower nonoolitic .... 10

Limestone, white, oolitic (quarry rock)........ 20

Limestone, nonoolitic, containing Talarocrinus and small bladelike Pterotocrinus............ 20

(The contact between Fredonia and Gasper may be a few feet above or below this horizon.)

Ste. Genevieve limestone (grouping atill in dispute), 170 feet:

Fredonia oolite member:

Mainly nonoolitic, generally pearl-gray and lithographic in texture; with some chert, particularly a few feet above the base .................. 70

Not exposed........................... 10

Limestone, white, oolitic (quarry rock)....... 40

Limestone, gray, colitic...................... 30

Limestone, oolitic........................ 20

The lower part of the section is best exposed at the Victoria quarry near Bowling Green. 
Chester grodp (IN WHOLE OR IN PART).

The Chester group (exclusive of the Ste. Genevieve limestone, the grouping of which is still in dispute) has been divided into several formations which crop out in the northwestern part of Warren County and in a belt surrounding the coal basin that extends from Warren County northwestward into Illinois and Indiana. It includes several of the producing sands of Illinois and in the northwestern part of Warren County is in places very asphaltic. To the west, in Crittenden and adjoining counties, it has been subdivided by Butts, ${ }^{1}$ above the Ste. Genevieve limestone, into the Bethel sandstone, Ridenhower shale, Cypress sandstone, Golconda formation, Hardinsburg sandstone, Glen Dean limestone, Tar Springs sandstone, Menard limestone, Palestine sandstone, and Clore formation.

\section{PENTSYLVANIAN SERIES.}

The Pennsylvanian or coal-bearing series of the Carboniferous system outcrops throughout an area including a dozen or more counties to the northwest of Warren. It consists largely of sandstone, which is developed topographically into the rough and rather high country visible at a distance of 10 miles to the northwest of Bowling Green.

\section{QUATERNARY SYSTEM.}

The rocks above described are covered almost everywhere by deposits of clay and sand, commonly more or less stony, belonging to several formations of Quaternary age. These deposits are of comparatively little interest to the oil prospector, except in regard to their thickness and whether or not they contain boulders. They include the alluvium underlying the bottom lands, commonly 5 to 15 feet thick; terrace deposits of sand and gravel, such as those that outcrop in the south part of Petroleum; and the products of weathering, slumping, or gradual creep of the older formations that mantle uplands and hillsides throughout the region. The thickness and hence the amount of drive pipe needed in drilling is generally only 5 or 10 feet but in places may reach 20 or 30 feet. All the surficial deposits are more or less stony and here and there contain boulders which locally make some trouble in drilling.

\section{STRUCTURE.}

GENERAL RELATIONS.

The dominant feature of the geologic structure of Allen and surrounding counties is the general northwestward dip. (See fig. 3.) Formations which outcrop along Cumberland River, 20 miles south of the State line in Tennessee, are buried to a depth of more than 2,000 feet along Green River, 15 or 20 miles north of Allen County. The average 
slope of the beds is consequently about 40 feet to the mile throughout the counties under discussion.

To judge from the arrangement of outcrops shown on geologic maps of the region, the Cincinnati and Nashville uplifts are connected by an area of much more gentle upwarp. Indeed, the outcrops of Devonian rocks in Allen County and the outcrops of Devonian, Silurian, and Ordovician rocks in Cumberland and Pulaski counties to the east and northeast suggest that there may be two axes of uplift trending northeast and southwest which connect the main broad domes to the northeast and southwest. However, the arrangement of outcrops is evidently in large part due to drainage lines and profiles of valley bottoms. (See fig. 10.) The details of structure can be determined only by extensive field work.

However, the Ordovician rocks, which underlie the coal basin of western Kentucky at a depth of 2,000 feet or more, are known to rise to the southeast until they lie less than 500 feet below the surface of Allen and Barren counties. They outcrop in Cumberland and adjoining counties but are again buried to a great depth beneath the coal basin of eastern Kentucky and Tennessee. On the other hand, a section from northeast to southwest through Allen County shows that these and older rocks outcrop in the region around Cincinnati and dip below the surface at Lebanon, 70 miles northeast of Scottsville. Southwest of Lebanon they gradually sink below the surface for perhaps 40 miles to Metcalfe County, the lowest part of the structural saddle. Further southwest they gradually rise and appear at the surface in the region around Nashville.

According to Hoeing, the general northwesterly dip is more irregular in Warren County than in Allen County, and in places, particularly along the front of a structural terrace which he has discovered in the northwestern part of Warren County, the dip is as great as 150 feet to the mile. The average strike in Warren County trends somewhat east of northeast and the direction of dip is between northwest and north. Along a line running through Mammoth Cave, 25 miles north of Scottsville, the strike is almost due north-northeast. To the southeast, in Allen and Monroe counties, the strike swings gradually eastward, finally reaching a direction considerably east of northeast. In detail the variation in the amount of dip nowhere exceeds a very few degrees. The strike ranges through almost every point of the compass, though throughout perhaps half the area it is not more than $20^{\circ}$ from northeast. The principal broad structural axes are one of upwarp, which connects the Nashville and Cincinnati uplifts, and one of depression, which crosses the uplift at right angles and connects the Appalachian and Eastern Interior coal basins. 
As topographic maps are not available for any portion of Allen County, and the altitude of few points has been determined, the conclusions concerning the structure of the region which have been brought to light are based largely upon determinations of relative altitude of different points on the same bed; in other words, the dip in different parts of the area. The report thus must be regarded as a contribution of fragments rather than the result of a complete survey. The fragments are, however, worth recording, one reason being that they throw light on the structure of the beds in which oil occurs in this region and are suggestive of the probable directions in which the known fields will be developed and afford some indication as to where new pools are most likely to be found. The farm lines and other geographic features in and around the producing areas are shown on Plate VII. The principal structural features in a portion of Allen County are indicated by the structure contours shown on Plates II and VIII and are here briefly described. The contour lines connect points on the upper surface of the Chattanooga black shale that have the elevation above sea level indicated on the line. The structure shown is therefore the depth of the surface of the black shale. This formation was chosen as the "key rock" because of the ease with which it is recognized in drill holes or outcrops and because of its proximity to the oil "sand," which was not contoured on account of the variable position occupied by the oil-bearing beds in the formations beneath the shale. It is fairly certain that a contour map based on the altitudes of the top of the pay sands would not be at all similar to a map that showed the structure of the Silurian and Devonian formations in which those sands occur.

\section{ACCURACY OF STRUCTURE CONTOURS.}

The contours shown on the large-scale map of the North Petroleum, Rodemer, and Wildwood pools (Pl. VIII) are based upon plane-table traverses by which the altitude of wells and of outcrops of the black shale was instrumentally determined. The starting point for the plane-table traverse was the old McCherry well No. 1 , in the town of Petroleum. The elevation of this well is reported by J. B. Hoeing to be 582.48 feet above sea level. The casing of the well has been pulled, and it is possible that the bench mark assumed departs as much as a foot in elevation from the figure given, and furthermore the level line may have been somewhat in error. On the other hand, the relative elevation of the wells as determined by the field work upon which this report is based and as given in the table (pp. 94-111) are probably correct within 2 feet in the limits of any one field, and within 10 feet in different fields. The elevation of the top of the well casing having been determined, the height of the black shale surface above sea level is readily ascertained by means of the driller's records. This, of course, introduces another possibility of error as 


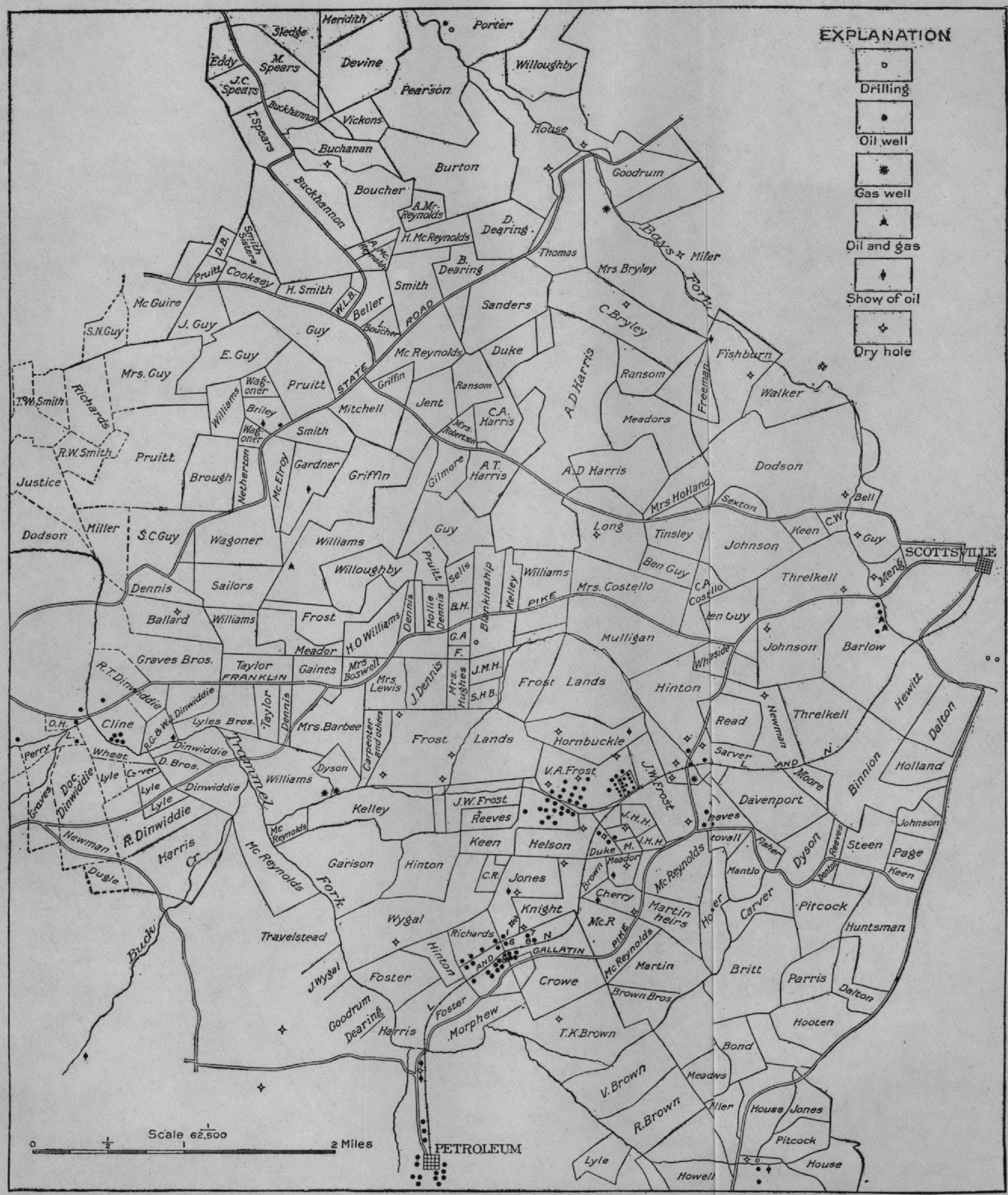

SKETCH MAP SHOWING FARM LINES AND WELLS IN THE SOUTH-CENTRAL PART OF ALEN COUNTY; KY.; WHERE MOST OF THE OIL-PRODUCING TERRITORY OF THE COUNTY IS LOCATED. 

the records are obviously not accurately obtained and many of them are carelessly preserved. Nevertheless, it is believed that the contours thus obtained give a fairly true idea of the structure of the "key formation" selected. Where the data are scarce or inharmonious, the contours are broken; where there is less room for doubt they are drawn as continuous lines.

Structure contours are also indicated on the small-scale map showing the geology of the greater part of Allen County (Pl. II). In the same area on the large-scale map of the oil fields, the contours have a similar accuracy. Elsewhere the indicated altitudes may be many feet in error, as some of them are based upon aneroid readings and others upon the gradient of streams.

\section{PRINCIPAL STRUCTURAL FEATURES.}

\section{ANTICLINES.}

The prevailing northwest dip of the strata in Allen County is modified by the presence of several small anticlines or domes. None of them is very extensive or very abrupt, but as far as known all have a longer axis which extends in an east-northeast or northeast direction, so that they display a roughly parallel arrangement. Doubtless there are many more of these structural features in and near the county than those shown on the accompanying map, whose presence would be revealed by a detailed geologic examination. As a rule a single dome is $1 \frac{1}{2}$ to 2 miles in length and three-quarters to 1 mile in width, with an area of 1 to 2 square miles.

North Petroleum anticline.-The North Petroleum anticline underlies the North Petroleum oil field. Its summit is near the M. B. Crowe well No. 7, and its longer axis extends in an east-northeast direction. It is traversed by Trammel Fork below the mouth of Little Trammel Creek. The stream has cut into the black shale to a depth of more than 15 feet, so that this formation outcrops along the northeast slope of the valley three-quarters of a mile below the Louisville \& Nashville Railroad bridge. Along the crest of the anticline the surface of the black shale is 25 feet higher than in the parallel trough toward the southeast. Toward the northeast the black shale descends at a decreasing rate until its dip coincides with the general or average dip of the strata throughout the region.

Rodemer anticline.-The Rodemer anticline is somewhat more extensive but not so high as the North Petroleum dome. It is nearly a mile north of the North Petroleum dome and underlies the Rodemer oil field. Its longer axis likewise trends east-northeast and its crest is slightly saddle-shaped with two summits a little over half a mile apart, one in the vicinity of the V. A. Frost well.No. 18 and the other near the Martha Keen well No. 13. The pool seems to extend much farther down the southeast slope of the dome than down the northwest slope. 
Petroleum anticline.-The Petroleum anticline extends east-northeast from the town of Petroleum and is traversed by Trammel Fork below the mouth of Rough Creek. It is the most pronounced dome yet discovered in Allen County and has not been adequately prospected for oil. The old as well as the more recent wells in and near Petroleum are on the extreme western flanks of this fold, whose summit is near Trammel Fork 1 mile east-northeast of Petroleum. The Chattanooga shale is sufficiently uplifted along the summit of this anticline to be exposed in the valley of Little Trammel Creek three-quarters of a mile above its mouth, and along Trammel Fork 1 mile above the Louisville \& Nashville Railroad bridge.

Rough Creek anticline.-The Rough Creek anticline was formed by a gentle flexure of the earth's crust in the region traversed by Rough Creek 2 miles above its mouth. Black shale outcrops along the stream at this point but disappears again upstream because of the eastward dip beyond the crest of the fold. So far as known there has been no attempt to find oil on this anticline.

The outcrop of Chattanooga shale along Snake Creek is apparently similar to that along Rough Creek, but field examinations indicate

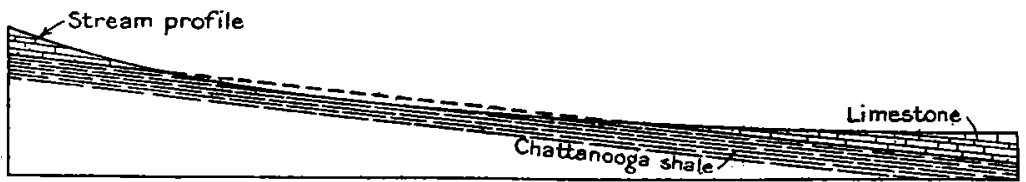

Figure 10.-Diagram illustrating a feature that suggests an anticline or dome but that is really due to a concave stream profile.

that it is not in reality due to the presence of a similar anticlinal arch. As indicated in figure 10, the concave profile of the ordinary stream may produce such a lenticular outcrop from a steadily dipping bed, such as the black shale in most parts of the country. The steeper gradient near the headwaters of Snake Creek has carried that stream down below the plane but tilted surface of the black shale. Farther downstream the gradient is more gentle and the dip of the beds projects the black shale below the stream channel.

Trammel anticline.-The Trammel anticline is crossed by Trammel Fork between the Kentucky-Tennessee line and the mouth of Snake Creek. Its axis probably trends northeast and southwest, but its extent toward the southwest is not known. As indicated on the geologic map, the anticline is a fairly pronounced one and brings not only the Chattanooga shale to the surface but exposes also the underlying "Corniferous" limestone.

Adolphus anticline.-The Adolphus anticline is three-quarters of a mile northwest of the town of Adolphus. Its trend is likewise toward the northeast, and it causes a second outcrop of black shale along Little Trammel Creek $1 \frac{1}{2}$ miles upstream from that caused by the 


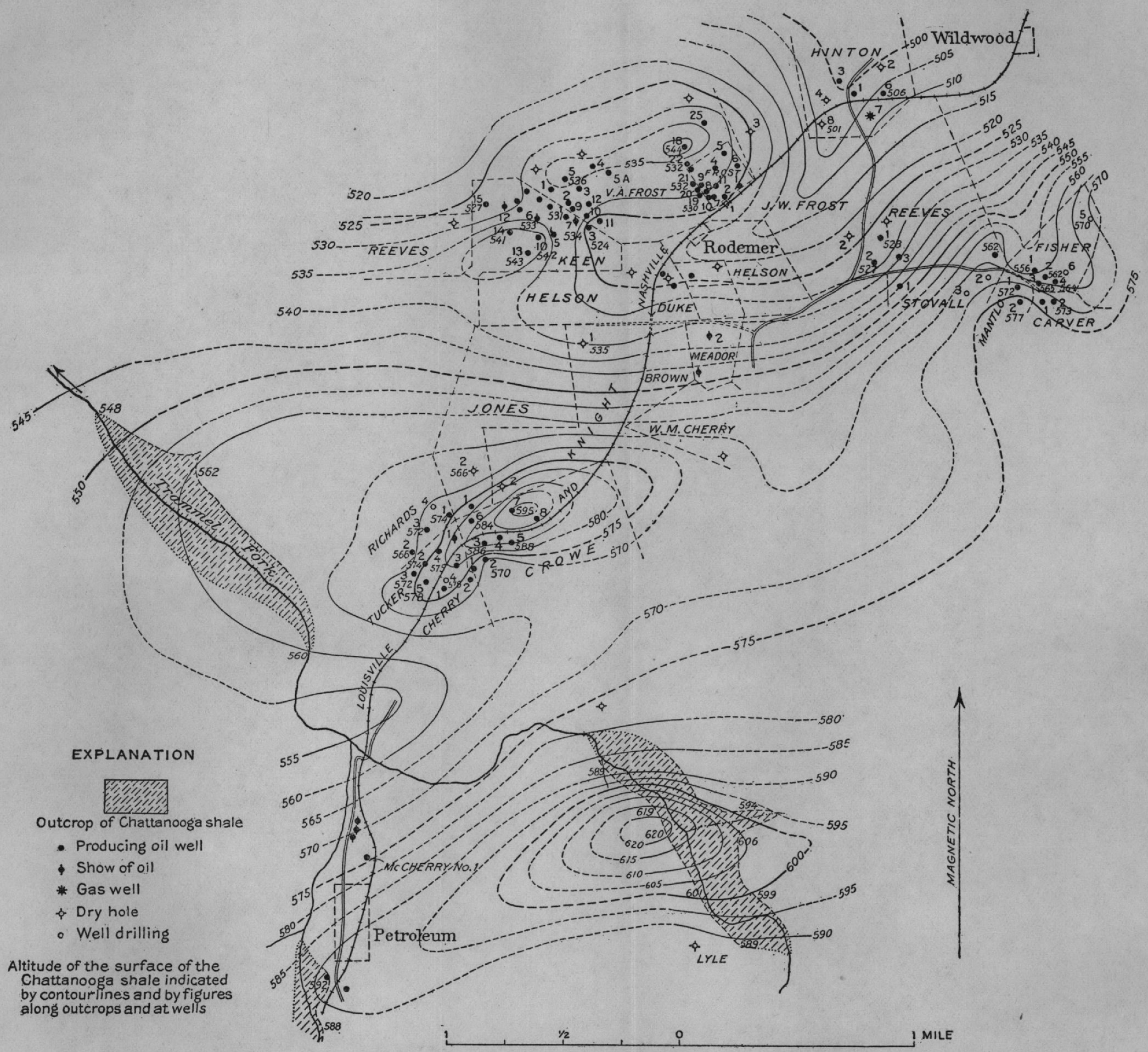

STRUCTURE MAP OF MAIN OIL POOLS OF ALLEN COUNTY, KY.

From plane-table survey by Kirtley F. Mather. 

Petroleum anticline. The summit of the Adolphus anticline is west of Little Trammel Creek and is probably due northwest from Adolphus station.

Other anticlines.-A small anticline is crossed by West Bays Fork 2 miles northwest of Scottsville. The limestones (Fort Bayne) at the bend in the stream slightly over a mile north from the Bowling Green pike dip nearly $2^{\circ} \mathrm{SE}$., but 2 miles farther downstream the same beds dip $1^{\circ} \mathrm{NE}$. Another small dome is crossed by East Bays Fork just below the Fountain Run road, which connects Scottsville with Maynard. Structural conditions there are identical with those just described.

The presence of so many small domes and anticlines in the parts of Allen County most thoroughly examined during the recently prosecuted field work is in itself an excellent basis for the inference that similar structural features are present in other parts of this and adjoining counties.

STICLIYES.

As a rule each of the anticlines described above is accompanied by a contiguous shallow syncline along its southeast margin. There are in addition to these synclines a few shallow structural depressions not closely related geographically to anticlinal warps.

Hinton syncline.-The Hinton syncline lies along the eastern flanks of the Rodemer anticline. Its presence is known from a study of drill records of wells whose elevations were determined. It is interesting chiefly because of the three producing wells which are situated along its bottom. Unfortunately, these wells lie at the margin of the producing fields and of the area instrumentally surveyed, so that the conclusions drawn are based upon somewhat inadequate data. Possibly there is a very small anticline within the Hinton syncline and if so the producing wells may be located upon it.

Turlock basin.-The Turlock basin is named from a discontinued post office on Rough Creek, 2 miles east of Petroleum. The surface of the black shale, as revealed in the Burd Miller and W. H. Miller wells, is 50 feet and more below the bed of Rough Creek at that locality. As indicated on the geologic map, the same formation crops out at higher levels toward the west, east, southeast, and south. The data amply justify the conclusion that the wells mentioned are near the bottom of a structural basin.

\section{RELATION OF OIL RESERVIOIRS TO STRUCTURE,}

The evidence derived from a comparison of the positions of producing wells and dry holes with the structural features of the Scottsville region is somewhat contradictory in its nature. The North Petroleum and Rodemer fields are very evidently situated directly over two of the more prominent anticlines described in the preceding 
section. Data concerning the Wildwood pool are not sufficient, at the present stage in its development, to demonstrate the presence of an anticline there, but all known facts concerining that field are in harmony with the presence of an anticline. The wells near and in Petroleum are situated on the flanks of the Petroleum anticline. The structural conditions around Scottsville are not known and the same is true of the area that contains the scattered wells in the west part of the county from which a good showing of oil is reported.

On the other hand, the Fishburn well No. 2 and the Walker well No. 1, both dry holes, are located near the summit of the small dome traversed by West Bays Fork, 2 miles northwest of Scottsville. Tests of the similar anticline along East Bays Fork, 2 miles northeast of Scottsville, have yielded one dry hole and one rather poor showing of oil. It is noteworthy that the Fisher well No. 5 in the Wildwood pool, although drilled where the surface of the black shale is from 5 to 8 feet higher than in wells Nos. 1 to 4 on the same lease, is a dry hole, whereas each of the other four wells is a good producing well. On the Corner lease wells Nos. 1 and 2 are drilled within 200 feet of each other in locations equally favorable so far as structure is concerned, yet No. 1 is a 100-barrel well and No. 2 produces scarcely 5 barrels a day.

Probably much more significant, so far as the structural relations of the accumulation of oil are concerned, are the facts derived from the study of the Hinton and Miller wells. On the Hinton lease there are three producing wells which are apparently situated in the bottom of a structural depression, the Hinton syncline. The data are not altogether conclusive concerning the structural relations of the Hinton wells but are sufficient to give considerable confidence in the correctness of the structure contours as drawn for this locality. Again, the Burd Miller and W.H.Miller wells (pp. 107, 108) are undoubtedly in the lower part of the Turlock basin. In May, 1917, none of the five wells drilled on these two leases had been pumped; since then it is reported that three of the five have proved to be good producing wells. There is much more water in the Hinton and Miller holes than in the average oil wells in Allen County.

From these somewhat contradictory data it may be safely affirmed that the structural features in Allen County exert a strong influence upon the location of oil reservoirs but do not by any means absolutely control their position. The controlling factor in some places is the composition and porosity of the oil-bearing limestone. This subject will be discussed subsequently under the heading "Character and position of the 'pay sands" " (pp. 71-75). The conclusion is justifiable, however, that in Allen and adjacent counties, as in the great majority of oil fields elsewhere, there is much more likelihood of the presence of oil reservoirs beneath localities of anticlinal structure than elsewhere. 
CONVERGENCE OF BEDS.

The structure maps fall short of showing the precise lay of the petroliferous formations, not only because of the scant data on which they are based but also because they represent as nearly as possible with present knowledge the structure of a surface which is itself not parallel to the underlying formations. The Chattanooga shale is considerably thicker toward the northwest from Scottsville than toward the south and southwest. Other things being equal, the oil sands would be found at a greater distance below the contoured surface in and near Warren County than in the central or southern part of Allen County. The spacing of beds farther apart, as, for example, the St. Louis limestone and the oil-bearing formations, is still less uniform on account of the similar increase in thickness of the Fort Payne chert. The top of the "Corniferous" limestone is 520 feet below the base of the St. Louis limestone near Bowling Green and only 305 feet near Scottsville.

JOINTS.

Joints are prominently developed in the region, particularly in the Chattanooga shale, and in the more massive limestones. In softer and more plastic beds, such as the shale found here and there in many of the formations, joints are obscure or lacking.

Observations of joints are of interest in the study of an oil pool principally because the joints in some places form channels for the migration of oil and gas, and because they may throw some light on the forces which warped the rocks and produced the structural features in which the oil is found. In Allen County the most prominent set of joints trends between N. $40^{\circ}$ E. and N. $60^{\circ}$ E. Most of them are nearly vertical, but a few were observed to dip $3^{\circ}$ to $18^{\circ}$ from verticality.

\section{CHARACTER AND POSITION OF THE "PAY SANDS."}

The oil of the producing fields in Allen County is derived from porous beds which lie beneath the Chattanooga shale, either just below it, or at a maximum depth of 140 feet below it. The conclusion seems justifiable that the pay sands occur in two formations of somewhat similar lithology but of quite different age; the "Corniferous" limestone of Devonian age and the Silurian limestone. Much doubt has prevailed as to the identification of the oil-bearing beds in many fields of Kentucky, particularly those in the western part of the State, and inferences regarding this identity have not been harmonious. The oil "sand" has sometimes been spoken of as the "Clinton limestone," but it seems very improbable that it is equivalent to the Clinton formation. In the western part of the county there are at least three wells in which a strong showing of oil was 
found at an altogether different horizon, above rather than below the black shale. It is probable that one of these wells may be a small producer.

Reservoirs of oil at this same horizon have been tapped in Barren County. The "sand" above the black shale may be correlated with the Beaver Creek "sand" of Wayne County 70 miles to the east.

$$
\text { "SANDS" IN THE "CORNIFEROUS" LIMESTONE. }
$$

In Plate III are plotted the positions of oil and water bearing beds which have been penetrated beneath the black shale in wells in Allen County. The porous zones or beds are correlated with each other by using the base of the shale as the datum plane in each log. The number, thickness, and relations of the oil "sands" are thus graphically shown. A glance at this plate shows that in the Rodemer field most of the wells have drawn their supply of petroleum from beds less than 50 feet below the black shale. These beds are believed to occur in the "Corniferous" limestone, although this conclusion can not be categorically affirmed.

The "Corniferous" limestone (pp. 47-48) at its outcrop along Trammel Fork, Long Creek, and Barren River, 4, 8, and 12 miles distant from the producing fields, occupies the same stratigraphic position as that of the petroliferous formation in the Rodemer field - that is, it immediately underlies the black shale. Samples of the oil sand and the outcropping rock have also been carefully compared and they seem to be altogether similar lithologically. The identification must remain doubtful, however, as this same stratigraphic position is occupied in northern Tennessee by another dolomitic limestone of Silurian age, which must underlie the "Corniferous" limestone in the Rodemer field if this interpretation of the age of the Rodemer "sand" is correct. It is more than probable that the blue-green clay shale which lies 45 feet below the black shale in the Keen well No. 5 marks the break between the two limestones. A similar lithologic ehange is reported in the Meredith well No. 1 at 65 feet and in the Tabor well No. 1 at 56 feet below the shale.

The oil and gas bearing portion of the "Corniferous" limestone differs considerably from well to well in position within the formation and in thickness. In the Rodemer field it averages very close to 15 feet in thickness and is generally overlain by a cap rock of hard limestone from 3 to 12 feet thick. In color the oil "sand" is some shade of brownish gray. It is fairly well cemented and commonly shows much recrystallization, though it is full of minute cavities, most of which are intercommunicating, and hence it forms an excellent oil reservoir. Locally it contains comparatively large cavities and fissures, which when filled with oil give a large flow for a few days but soon become exhausted. Crevices within the "Corniferous" lime- 
stone are reported in the V. A. Frost wells Nos. 19 and 22, the Martha Keen well No. 10, and the Richards well No. 3.

The pay streaks in the dolomite seem to differ from the remainder in having larger pores and in being softer or less indurated. In many of the dry holes scattered throughout the county, the "Corniferous", is a fine-grained bluish or brownish dolomitic limestone, so hard and "tight" from top to bottom that it could contain neither oil nor water in recoverable amount. Dolomites commonly have a sandy texture due to solution and recrystallization, but the shapes of the pores and their connections differ markedly from those of a sandstone that is composed of grains of quartz sand brought together by water or wind. One of the principal differences is that the variation in texture of the dolomite does not closely follow the bedding, as it generally does in sandstones, and the query naturally arises if the texture may be due in part to the presence of oil.

Wherever it is exposed at the surface the "Corniferous" limestone displays an abundance of cavities, both small and large. Typically the outcropping beds are pitted and corroded so that they have a coarse "honeycomb" texture. (See Pl. III.) In places the joint planes form vertical fissures, and elsewhere certain beds seem to be more readily dissolved than others, but in general the pores and cavities are developed irregularly without any special reference to such features.

Obviously part of the pore space observed at outcrops was produced by agents of surface weathering which have been acting upon the rock only since the removal of the black shale and the development of the existing topography at these localities. In particular the calcite. grains, which dissolve more readily than the dolomite, leave a mass of porous grains of dolomite poorly cemented together. Porosity thus developed of course had no influence upon the accumulation of oil. On the other hand, it is demonstrable that the dolomitic limestone was exposed to weathering for a long interval before the deposition of the black shale upon it. It is conceivable that weathering in Devonian time may have produced an effect upon the exposed portions of the "Corniferous" limestone exactly similar to that produced in recent time. Certain portions of the formation would thus be rendered suitable for the retention of oil after the black shale had been deposited.

No direct evidence has been obtained bearing upon the thickness of the "Corniferous" limestone in the North Petroleum field, but it seems very likely that the "sands" there penetrated within 50 or 60 feet of the black shale are in that formation. The deeper sands are doubtless in the Silurian limestone. In the same way, the sands in the Reeves wells and near the black shale in the Fisher wells Nos. 4 and 5 , in the Wildwood field, may be referred to this formation. 
"SANDS" IN THE SILURIAN LIMESTONE.

The oil sand in most of the wells in the North Petroleum and Wildwood fields is found at depths of 50 to 130 feet below the base of the Chattanooga shale. In certain wells in the Rodemer field the "Corniferous" pay zone has been passed through and oil or water bearing sands have been penetrated at deeper levels. The conclusion seems altogether justified that these "sands" are in the Silurian limestone.

This limestone crops out along Trammel Fork beginning near the Kentucky-Tennessee line, 6 miles southest from the North Petroleum field, and extending an unknown distance up the creek valley. Better exposures are found along the Scottsville-Gallatin pike, 10 miles south of Adolphus. In many ways it resembles the "Corniferous" limestone, which in most localities overlies it but which is not present at the two outcrops mentioned. The Silurian limestone has a sandy texture and contains a variable amount of sand grains. Certain of the upper beds might be described as calcareous sandstones, although it is probable that the proportion of sand in them is exaggerated at the outcrops by the surface leaching of the lime, so that under cover they are merely sandy limestones. This Silurian limestone does not display the numerous fissures and large cavities which characterize the "Corniferous," but this is more than balanced by the abundance of small openings and pores which probably intercommunicate. Lithologically the Silurian limestone is better suited than the "Corniferous" for a reservoir of oil and gas.

Pay "sands" occur at variable positions within the Silurian, but in most wells the top and bottom of the system are not defined, so that definite statements concerning the position of the pay are not warranted. In many of the wells, such as the Crowe No. 7, Richards No. 4, Mantlo No. 3, Fisher Nos. 2, 3, and 4, and Carver No. 1, pay streaks have been penetrated at two or three levels within the formation. Altogether the pay portion of the Silurian limestone averages between 16 and 17 feet in thickness in the Wildwood field and between 9 and 10 feet in the North Petroleum field. The pay "sands" in the Rodemer field, which are safely referable to this formation, are 12 to 15 feet thick.

\section{BEAVER CREEK (?) "SAND."}

Three of the wells in the western part of Allen County have penetrated oil-bearing strata above the black shale. One of the three, the Cal Guy well No. 2, is reported to show enough oil to justify pumping, although at the time of writing no pump had been installed. In this well the interval between the oil "sand" and the black shale is stated to be 15 feet; in the Rush well No. 1 it is 68 feet and in the Stamps well No. 1 it is $2 \frac{1}{2}$ feet. In many other wells 
that are just as far as these from the outcrops of the strata no showing of oil is reported at these horizons.

The New Providence shale and the Fort Payne chert are similar in many respects to the "Waverly" shales of Wayne County, $\mathrm{Ky}_{\text {., }}$ in which the Beaver Creek "sand" is found under analogous stratigraphic relations. Certain of the more porous beds are well adapted to retain petroleum, and reservoirs of oil at this horizon may be discovered in western Allen County similar to those recently tapped in Barren County, which are described elsewhere (p. 113).

\section{Character OF THE OIL.}

\section{OIL BELOW THE BLACK SHALE.}

The oil derived from the "Corniferous" and Silurian limestones in Allen County is dark green and opaque except in masses only an eighth of an inch or less in thickness. Its specific gravity is generally between $23^{\circ}$ and $33^{\circ} \mathrm{B}$. Samples collected from different parts of the county have been analyzed by the Bureau of Mines, with the results indicated in the following table: 
Results of distillation of oils from Allen County, $K y$.

[Distillation by Bureau of Mines in Hempel flask; Ernest W. Dean, chemist. Samples collected in May, 1917; distilled in July, 1917.]

\begin{tabular}{|c|c|c|c|c|c|c|c|c|c|c|c|c|c|c|c|c|c|c|c|c|}
\hline & \multicolumn{4}{|c|}{1} & \multicolumn{4}{|c|}{$\mathbf{2}$} & \multicolumn{4}{|c|}{3} & \multicolumn{4}{|c|}{4} & \multicolumn{4}{|c|}{5} \\
\hline 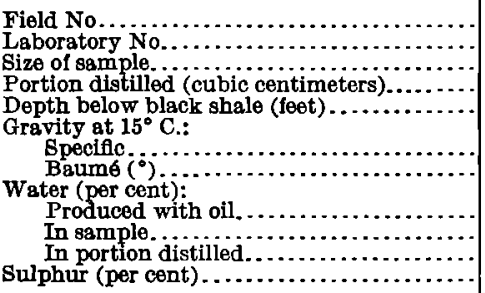 & & & & $\begin{array}{r}24 \\
2142 \\
200 \\
58 \\
0.910 \\
23.8 \\
20-50 \\
\text { None. } \\
1.814\end{array}$ & & & Consider & $\begin{array}{r}0.880 \\
29.1 \\
\text { rable. } \\
\text { ittle. } \\
\text { None. } \\
1.434\end{array}$ & & & 8 ou & $\begin{array}{r}27 \\
2144 \\
\text { ances. } \\
125 \\
5-45 \\
0.885 \\
33.7 \\
\text { rable. } \\
25 \\
\text { Trace. } \\
1.718\end{array}$ & & & & $\begin{array}{r}31 \\
2145 \\
\text { rallon. } \\
200 \\
78-93 \\
0.863 \\
32.2 \\
\text { Little. } \\
\text { None. } \\
1.154\end{array}$ & & & $\begin{array}{r}80 \\
\text { Above }\end{array}$ & $\begin{array}{r}49 \\
2146 \\
\text { ounces. } \\
150 \\
\text { shale. } \\
0.808 \\
43.3 \\
\text { one (?) } \\
\text { None. } \\
0.165\end{array}$ \\
\hline First drop $\left({ }^{\circ} \mathrm{C}.\right) \ldots \ldots \ldots \ldots \ldots \ldots \ldots \ldots \ldots \ldots \ldots \ldots$ & \multicolumn{4}{|r|}{80} & \multicolumn{4}{|r|}{72} & \multicolumn{4}{|r|}{25} & \multicolumn{4}{|r|}{30} & \multicolumn{4}{|r|}{25} \\
\hline \multirow[t]{2}{*}{ Pressure (millimeters)...................... } & \multicolumn{3}{|c|}{ Air: 735.} & $\mid \begin{array}{c}\text { Vac- } \\
\text { uum: } \\
40 .\end{array}$ & \multicolumn{3}{|c|}{ Air: $\mathbf{7 4 0 .}$} & $\begin{array}{c}\text { Vac- } \\
\text { uum: } \\
40 .\end{array}$ & \multicolumn{3}{|c|}{ Air: 737.} & $\mid \begin{array}{c}\text { Vac- } \\
\text { uum: } \\
40 .\end{array}$ & \multicolumn{3}{|c|}{ Air: $\mathbf{7 4 0}$} & $\begin{array}{c}\text { Vac- } \\
\text { uum: } \\
40 .\end{array}$ & \multicolumn{3}{|c|}{ Air: $\mathbf{7 4 0}$. } & $\begin{array}{c}\text { Vac- } \\
\text { uum: } \\
40 .\end{array}$ \\
\hline & $\begin{array}{c}\text { Frac- } \\
\text { tion } \\
\text { (per } \\
\text { cent). }\end{array}$ & $\mid \begin{array}{c}\text { Total } \\
\text { (per } \\
\text { cent) }\end{array}$ & $\begin{array}{c}\text { Spe- } \\
\text { cific } \\
\text { grav- } \\
\text { ity of } \\
\text { frac- } \\
\text { tions. }\end{array}$ & $\begin{array}{c}\text { Total } \\
\text { (per } \\
\text { cent). }\end{array}$ & $\begin{array}{c}\text { Frac- } \\
\text { tion } \\
\text { (per } \\
\text { cent). }\end{array}$ & $\mid \begin{array}{c}\text { Total } \\
\text { (per } \\
\text { cent) }\end{array}$ & $\begin{array}{l}\text { Spe- } \\
\text { ciffc } \\
\text { grav- } \\
\text { ity of } \\
\text { frac- } \\
\text { tions. }\end{array}$ & $\begin{array}{c}\text { Total } \\
\text { (per } \\
\text { cent). }\end{array}$ & $\mid \begin{array}{c}\text { Frac- } \\
\text { tion } \\
\text { (per } \\
\text { cent). }\end{array}$ & $\begin{array}{c}\text { Total } \\
\text { (per } \\
\text { cent) }\end{array}$ & $\begin{array}{l}\text { Spo- } \\
\text { cific } \\
\text { grav- } \\
\text { ity of } \\
\text { frac- } \\
\text { tions. }\end{array}$ & $\mid \begin{array}{c}\text { Total } \\
\text { (per } \\
\text { cent). }\end{array}$ & $\begin{array}{c}\text { Frac- } \\
\text { tion } \\
\text { (per } \\
\text { cent). }\end{array}$ & $\left|\begin{array}{c}\text { Total } \\
\text { (per } \\
\text { cent). }\end{array}\right|$ & $\begin{array}{c}\text { Spe- } \\
\text { cific } \\
\text { grav- } \\
\text { ity of } \\
\text { frac- } \\
\text { tions. }\end{array}$ & $\begin{array}{c}\text { Total } \\
\text { (per } \\
\text { cent). }\end{array}$ & $\mid \begin{array}{c}\text { Frac- } \\
\text { tion } \\
\text { (per } \\
\text { cent). }\end{array}$ & $\begin{array}{c}\text { Total } \\
\text { (per } \\
\text { cent) }\end{array}$ & $\begin{array}{c}\text { Spe- } \\
\text { cffic } \\
\text { grav- } \\
\text { ity of } \\
\text { frac- } \\
\text { tions. }\end{array}$ & $\begin{array}{c}\text { Total } \\
\text { (per } \\
\text { cent). }\end{array}$ \\
\hline 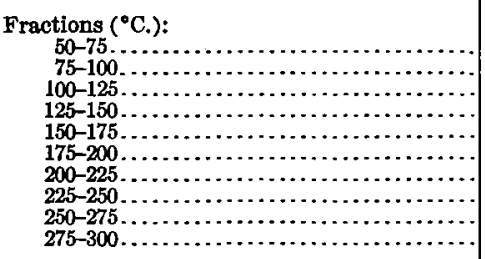 & {$\left[\begin{array}{r}\cdots \\
3.4 \\
6.3 \\
9.3 \\
13.5\end{array}\right.$} & $\begin{array}{r}3.4 \\
9.7 \\
19.0 \\
32.5\end{array}$ & 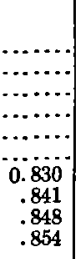 & $\begin{array}{r}1.6 \\
9.9 \\
20.6 \\
32.6\end{array}$ & $\begin{array}{r}2.4 \\
2.6 \\
6.2 \\
3.1 \\
4.5 \\
5.2 \\
6.8 \\
7.5 \\
10.7\end{array}$ & $\begin{array}{r}2.4 \\
5.0 \\
11.2 \\
14.3 \\
18.8 \\
24.0 \\
30.8 \\
38.3 \\
49.0\end{array}$ & $\begin{array}{l}0.763 \\
.763 \\
.784 \\
.812 \\
.812 \\
.826 \\
.836 \\
.844 \\
.849\end{array}$ & 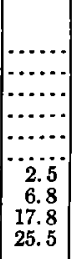 & $\begin{array}{l}3.2 \\
5.0 \\
6.5 \\
6.8 \\
4.6 \\
4.5 \\
5.4 \\
6.2 \\
6.6\end{array}$ & \begin{tabular}{|r|}
3.2 \\
8.2 \\
14.7 \\
21.5 \\
26.1 \\
30.6 \\
36.0 \\
42.2 \\
48.8
\end{tabular} & $\begin{array}{r}0.721 \\
.721 \\
.755 \\
.777 \\
.824 \\
.824 \\
.840 \\
.845 \\
.849 \\
. .8 .\end{array}$ & 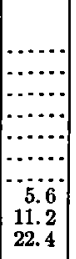 & $\begin{array}{l}4.4 \\
4.1 \\
5.0 \\
5.7 \\
4.0 \\
4.7 \\
4.7 \\
5.2 \\
6.5 \\
7.3\end{array}$ & \begin{tabular}{|r|}
4.4 \\
8.5 \\
13.5 \\
19.2 \\
23.2 \\
27.9 \\
32.6 \\
37.8 \\
44.3 \\
51.6
\end{tabular} & $\begin{array}{r}0.668 \\
.734 \\
.757 \\
.777 \\
.798 \\
.814 \\
.830 \\
.841 \\
.850 \\
.857\end{array}$ & 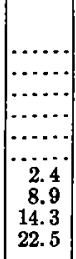 & $\begin{array}{l}8.6 \\
6.7 \\
7.6 \\
6.0 \\
5.2 \\
5.0 \\
4.9 \\
5.5 \\
5.2 \\
6.0\end{array}$ & $\begin{array}{r}8.6 \\
15.3 \\
22.9 \\
28.9 \\
34.1 \\
39.1 \\
44.0 \\
49.5 \\
54.7 \\
60.7\end{array}$ & \begin{tabular}{|c|}
0.671 \\
.725 \\
.745 \\
.764 \\
.782 \\
.800 \\
.816 \\
.827 \\
.835 \\
.843
\end{tabular} & $\begin{array}{r}\ldots \ldots . . \\
\cdots \ldots . . . \\
\cdots \ldots . . \\
\cdots \ldots . . \\
\cdots \cdots . . . \\
\cdots \cdots . . \\
\cdots \cdots . . \\
8.0 \\
16.1 \\
23.2\end{array}$ \\
\hline
\end{tabular}


1. Barlow wells, half a mile southwest of Scottsville. Sample dipped from tank. Flash point in Pensky-Martens closed cup, $68^{\circ} \mathrm{C}$. Contained considerable $\mathrm{H}_{2} \mathrm{~S}$.

2. Hinton wells, in syncline 4 miles northeast of Rodemer pool. Sample dipped from tank; developed $\mathrm{H}_{2} \mathrm{~S}$ on distillation.

3. Brown sediment from Keen wells Nos. 2, 8, and 9, Rodemer pool (best wells on lease). Sample from pipe while pumping consisted of water 25 per cent, sediment 24 per cent, and oil 51 per cent. Some $\mathrm{H}_{2} \mathrm{~S}$. Air fractions above $225^{\circ}$ brown.

4. Carver well No. 1, Wildwood pool ("best well in pool"). Sample from "big pay," taken from pipe while pumping. Some water and brown sediment.

5. Austin well No. 2, 3 miles northwest of Glasgow. "Amber oil." Sample from bailer; too small to get accurate results.

\section{“ AMBBER OIL."}

The oil from the Beaver Creek (?) "sand" above the black shale is lighter in color, with a yellowish-brown or amber tint in films thin enough to transmit light.

\section{GAS.}

Some gas has been found in a good many wells in Allen County and surrounding territory, particularly west and northwest of the Rodemer field. Whether the gas existed as gas in pores of the rocks before drilling was done or whether it was largely dissolved in the oil is not known. It is beyond doubt that if some of the oil and gas from this region were put under pressure together the gas would dissolve in the oil to some extent, and hence it is presumable that under the pressures prevalent in the earth much of the gas was so dissolved and has been liberated at wells where the pressure was relieved.

Most of the wells yield relatively little gas. Col. M. W. Crump, of Bowling Green, reports that the gas pressure in the wells to the southeast of Bowling Green amounted to 20 to 50 pounds to the square inch.

The J. L. Williams well burns with a flame 15 feet high; several other wells yield a steady flow, but no figures for open or closed pressure are available.

\section{WATER.}

Salt water is present in certain parts of the oil-bearing portions of the "Corniferous" and Silurian limestones throughout Allen County. In the majority of wildcat wells drilled at some distance from the producing fields no water-bearing beds are reported to have been encountered. Most of the limestones beneath the black shale were found to be so little porous that they would yield no flow of either water or oil. On the other hand, large quantities of salt water have been pumped from several wells in and near the producing fields. As a rule such wells are located far down the slopes of the domes; for example, the Richards wells Nos. 1, 2, and 3, on the east flank of the North 
Petroleum anticline were yielding more water than oil in May, 1917. The Hinton and Miller wells, located in the Hinton syncline and the Turlock basin, respectively, contain a considerable percentage of water.

In many wells a water-bearing stratum is reported at different distances below the oil pay. The interval of comparatively impervious beds between the oil "sand" and the water "sand" in a few of the wells is reported as follows: V. A. Frost well No. 17, 27 feet; V. A. Frost well No. 23, 5 feet; V. A. Frost well No. 24, 21 feet; Martha Keen well No. 14, 43 feet. In the Mantlo well No. 3, the water "sand" immediately underlies the deepest pay stratum. A heavy flow of water was encountered in the Richards well No. 3 at 7 feet above the upper pay sand, and another water zone was tapped between the two petroliferous "sands."

A strong flow of water may indicate a gas pool near by, for the friction of flow under such circumstances is apparently far less than it would be if no gas were present. Suppose an open-pored sandstone 1,000 feet below the surface contains a gas pool 2 miles in diameter and 10 feet thick under a pressure of 400 pounds to the square inch, and suppose this open-pored sandstone has practically impervious clay above and below it but is continuous, rises gradually to an outcrop 50 miles away, and, except in the part occupied by gas, is filled with water, the pressure on the gas being due mainly to the weight of the water. Then if a well penetrates the sand 200 feet from the gas pool, as the rock pores are large, freely connecting and filled with water, the yield will be great, for the rate of flow of water through a group of tubes depends not only on the pressure, the diameter of the tubes, and other factors, but on the length of the tubes.

As the water flows into the well the gas pressure behind it is relieved somewhat but only at a very slow rate, because of the large volume of gas. If 100 barrels of water a day were pumped from the well for a year the pressure on the gas would be relieved less than 0.5 per cent, so that the effect of declining pressure is practically negligible.

The water in the sand between the pool and the outcrop will also move toward the well but only very slowly, for the openings or tubes through which it flows are 50 miles long, and the reduction of the opposing gas pressure is very slight.

On the other hand, if the supposed conditions were the same except that there were no gas pool the amount of water entering the well would be much less, for it would depend on the rate of flow, with practically the same pressure and diameter of tubes as before, through tubes 50 miles long instead of 200 feet. Conditions would then be simply artesian, and the fact that artesian flows are so copious is believed by the writer to indicate that the artesian sands are more 
open and uniform over large areas than the oil and gas sands. It seems probable, moreover, that many of the artesian sands have at one time or another carried oil and gas, either in pools or in scattered droplets, but that because they lack barriers or fine-pored parts the oil and gas, together with the connate salt water, have been replaced by fresh water.

A pervious rock that is penetrated in a well but that fails to yield water, oil, or gas is commonly said to be dry, though such a bed may contain much water. If the bed is lens-shaped and surrounded by impervious clay so that no water can enter it to take the place of any that would otherwise flow out into the well, it may seem to be dry or it may yield its water very slowly. Drilling water or, in the absence of drilling water, capillary forces may prevent the relief of pressure in the sand by a flow of water or air into the upper part of the pay while water flows out into the well from the lower part. On the other hand, if the bed is not far below the surface it may be above the level of the main body of ground water and thus be really dry or rather have its pores filled with air and a very little water instead of being almost full of water. In some places an essentially dry sandstone may lie between two beds that contain water, the upper water-bearing bed being filled with perched ground water-that is, water whose natural downward movement is prevented or checked by an impervious layer. It seems probable that many of the deep-lying so-called dry sands really contain much water, but either they are so sealed in that they can not give up their water or else they have a good outlet at a lower altitude, and the hydraulic head of the water is less than the weight of drilling water standing in the well so that the water flows down into the sand layer instead of out into the well. Conditions may exist under which a sand that is actually full of water, if the water is in motion, may take up water that is poured into a well for drilling. The sand may be relatively open throughout, and outcrops or other outlets on one or more sides may be lower than the well, or it may have a poor intake. The pressure on the flowing water in the pores at the well may thus be less than that exerted by a column of water standing in the well.

Thus the failure of a well to yield water does not prove that the sand contains little or none, or even that it is not saturated, for if a layer or mass of porous rock within the earth-such as a lens of sand-is saturated with water but sealed off from other layeis containing water, oil, or gas which could flow in to take its place, its water would probably not flow out into a well, particularly if the sand lens is small. If the well penetrates a great thickness of the porous bed and only a little drilling water is used, it is conceivable that air might flow from the well into the upper part of the bed while water flows out from the lower part, but the process might be slow because of the low dif- 
ferential pressure and the considerable friction involved. Also, the larger the lens of sand, the greater the opportunity for water to flow into it from adjacent beds to take the place of that tending to flow out into the well. Suppose a well derives a little water from a sand lens comparatively well sealed in with shale of uniform character. Then presumably at the upper and lower surfaces of the sand lens is a stream or current of water of immense area in cross section-perhaps a square mile or more-but divided into innumerable minute threads by the slit and clay particles of the shale. The friction is so great that it can move only at an extremely slow rate. At the well, on the other hand, there is a current of water of small area in cross section and divided into larger threads by sand grains, so that movement can be much more rapid.

The composition of the water associated with the oil in Allen and adjoining counties is indicated by the following partial analysis. Its dominant characteristic, like that of other oil-field waters, is that it contains much sodium chloride or common salt. The total quantity of salts of all kinds ranges from 6,460 to 80,440 parts per million. In no wells has fresh water been reported in association with the oil, and the range in salinity is surprisingly great.

Partial analyses, in parts per million, of salt water from Allen County oil fields.

[S. C. Dinsmore, analyst.]

\begin{tabular}{|c|c|c|c|}
\hline & $\begin{array}{l}\text { Sample } \\
54 .\end{array}$ & Sample & $\begin{array}{l}\text { Sample } \\
50 .\end{array}$ \\
\hline 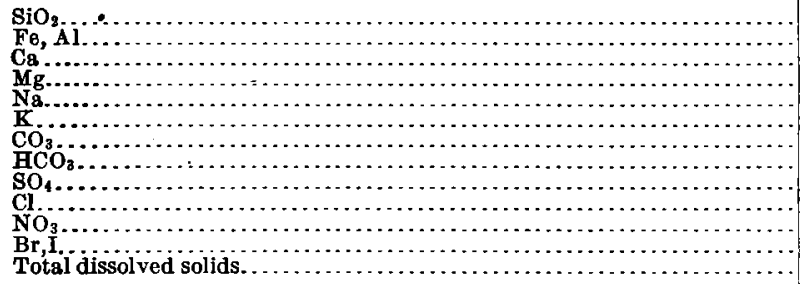 & $\begin{array}{r}80 \\
1.6 \\
176 \\
119 \\
1,836 \\
231 \\
3,4 \\
334 \\
1,711 \\
2,476 \\
0 \\
0 \\
6,460\end{array}$ & $\begin{array}{c}120 \\
3.4 \\
868 \\
363 \\
3,570 \\
270 \\
0 \\
0 \\
3,233 \\
7,509 \\
0 \\
\text { Trace. } \\
16,180\end{array}$ & $\begin{array}{r}140 \\
3.6 \\
3,760 \\
1,893 \\
20,811 \\
3,325 \\
154 \\
593 \\
3,616 \\
45,316 \\
0 \\
18 \\
80,440\end{array}$ \\
\hline
\end{tabular}

$a$ Water strongly acid in character.

Concerning the making of the analyses Mr. Dinsmore says:

I experienced some difficulty in getting satisfactory determinations of some of the radicles, particularly the carbonate and bicarbonate radicles in samples 50 and 54 . My first titration on sample 50 gave 154 parts per million of $\mathrm{CO}_{3}$ and 593 parts per million of $\mathrm{HCO}_{3}$. After treating a portion of the sample to eliminate the hydrogen sulphide, titrations gave 738 parts per million of $\mathrm{HCO}_{3}$. This sample was very highly mineralized and contained large, though undetermined, amounts of hydrogen sulphide. In titrating for carbonates and bicarbonates $I$ noticed that after the end point had been reached with phenolphthalein indicator, upon standing a few minutes the red color reappeared; this was also noticeable in the analysis of sample 54 and is something I have never noted in any sample of water that has come to me for analysis. In sample 54 the first titration gave 3.4 parts per million for the $\mathrm{CO}_{3}$ radicle and 334 parts 
per million for the $\mathrm{HCO}_{3}$ radicle. I took a measured portion of the sample, titrated for $\mathrm{CO}_{3}$ to the end point, repeating this operation until there was no reappearance of the red color, indicating that all of the $\mathrm{CO}_{3}$ radicle had been neutralized with the standard acid. When this was reached my calculations gave 309 parts $\mathrm{CO}_{3}$ and zero for the $\mathrm{HCO}_{3}$ radicle.

Sample 53 was acid in character and no number obtainable for the carbonate and bicarbonate radicles. I made bromine and iodine determinations on the three samples and obtained for sample 5018 parts per million, for sample 53, a very small amount, not more than a trace, and for sample 54, zero.

The wide range in salinity and the fact that the strongest brine is somewhat less salty than the average for oil fields suggests dilution or evaporation, perhaps because the sand lies not far below the surface. But evidently something more than dilution of concentrated brine has occurred, for not only the total salinity but the proportions of the various salts vary considerably. The large amount of potash in sample 50 may be due principally to some peculiar underground deposit, such as that known in the Mammoth and other caves. Although there are few large caves in Allen County innumerable small ones are scattered throughout the region.

The so-called mineral springs which occur here and there in the region contain much less mineral matter, and the proportions of various salts in solution are quite different from those in the water associated with the oil, which is much more like the salt water of other oil regions than like any mineral spring water, $\cdot$ both in total salinity and in proportions of various salts. Salt water has been known in the region for 70 years or more. About 1850 a well was sunk near Burksville for brine to be used in the manufacture of salt.

The composition of oil-field waters has importance in petroleum geology because it promises to throw light on the origin, accumulation, and perhaps quality of the oil. Oil-field waters are salty; so is ocean water. Many of the strata of oil fields are known to have been formed in the ocean, and the suggestion thus arises that the oil-field waters are fossil sea water or, as Lane ${ }^{1}$ has called them, connate waterwater of the ancient ocean in which the strata were formed. If so, there has been little or no free circulation of water in the rocks containing the salt water and oil in all the long periods of geologic time, and the oil was formed not far from its present position. On the other hand, accurate chemical analyses show that the oil-field waters differ more or less from present ocean water, and presumably from the ocean water of the distant past, being for one thing more concentrated. Whether these differences have been produced underground by the solution of salt beds or eraporation of the water, so that the oil-field water is somewhat modified sea water, or whether the oil-field water has had a different source is a matter of discussion.

1 Lane, A. C., Mine waters: Lake Superior Min. Inst. Proc., vol. 13, pp. 64, 125, 1906. $77677^{\circ}-19-B u l l .688 \longrightarrow 6$ 
If it came from far within the earth, perhaps the oil also came from great depths.

Although many rocks are spoken of as impervious, as a matter of fact all have pores and the so-called impervious rocks are only relatively so. Even the clay and shale which seal in oil and gas pools so effectively may actually have pores filled with water held by molecular attractions so strong that the oil and gas can not push the water out of the way and migrate through the bed. These forces are apparently not effective where the strata contain but one fluid-for example, water - hence it is conceivable that water might slowly migrate through rocks thousands of feet in thickness. On the other hand, the available evidence seems to the writers to indicate that neither water nor oil has a distant source, and that the water and oil of oil fields have not migrated far from their original position.

It is often suggested that salt water exerts some kind of a pickling effect on the remains of organisms that become buried in the sediments which now constitute the strata of rock, and that the products in thousands or millions of years under the conditions existing in nature's underground laboratory are petroleum and gas. This hypothesis seems rather doubtful, but the salts dissolved in water, particularly those containing chlorine and iodine, may affect the quality of the oil if they do not control its development.

\section{CAPACITY AND LIFE OF WELLS AND AMOUNT OF OIL STILL IN THE POOLS.}

Basis for estimating productivity.--The estimation of how much oil can be extracted from the pools in Allen County is a difficult problem. One reason for the difficulty is that, as the field is young, little enlightening information is available concerning the life and production curves of individual wells and the wells have not been worked to their full possibilities; another reason is that the pore space of the oil "sand" is apparently very irregular. In some places the "sand" (or dolomite) is compact; elsewhere it has an abundance not only of small pores but also of cavities of different sizes. Some of these cavities may be nearly closed, so that even though filled with oil they may give it up at so slow a rate that the wells may be abandoned before even a large part of it has been extracted.

A few specimens collected at an outcrop of a bed believed to be equivalent to the oil sand near Holland were tested roughly for pore space and found to have about 28 per cent of space between grains. Precise determinations were not thought warranted, principally because the outcropping rock has been subjected to leaching and if it contained a mixture of calcite and dolomite the calcite would likely be dissolved before the dolomite, and also because of the possibility that the outcropping bed may not be equivalent to the 
oil sand. Even if it were, the oil may have collected in a part of the sand which has unusually large pores. Some small fragments of the oil sand were obtained from wells, but as the pores of the rock evidently have a great range in size the small fragments obtained may represent the more compact portions of the bed, and hence their space must be regarded as minimum.

The pore space of all oil-bearing rocks elsewhere is, so far as known, above 15 per cent and probably averages between 20 and 25 per cent, though some specimens reach 30 per cent or more. The average thickness of the "pay" portion of the Allen County sand is in the North Petroleum pool about 20 feet, in the Rodemer pool about 15 feet, and in the Wildwood pool about 17 feet. The areal extent of the known portions of these pools is respectively $0.10,0.16$, and 0.12 square mile. If the pore space filled with oil amounts to 20 per cent of the volume of the rock, as it seems to do in many oil fields, the actual quantity of oil so far discovered in the three pools would be about $32,000,000$ cubic feet. It seems probable, however, that a part of the pore space in the "pay" portion of the sand is occupied by gas, and perhaps a part by water, which may occur in thin streaks and perhaps as the lining of pores, so that the estimated quantity of oil should be discounted perhaps 25 per cent or more on this account. After making reasonable allowances for all conceivable sources of error, it seems probable that the three main pools contained at the beginning about $20,000,000$ cubic feet or $3,540,000$ barrels of oil, of which only a small fraction has been extracted.

Percentage of oil recoverable.-Another question of great importance concerns the percentage of oil which may be recovered from a sand. Estimates of pore space, thickness, and extent of "pay" in certain old oil fields leads to the inference that less than half of the oil in a pool is ordinarily recovered. The fact that when water penetrates an oil-soaked fine-grained material much of the oil is left behind also indicates that unless special devices or methods are used, the fraction of oil recovered is relatively a small part of the whole. Some experiments have been performed by Dunn and Smith, ${ }^{1}$ by J. O. Lewis, ${ }^{2}$ and by $\mathrm{E}$. W. Shaw ${ }^{1}$ to give further information on the percentage of oil which is ordinarily recovered, and also for the purpose of suggesting means by which the percentage recovered can be increased. If half the amount of the oil is actually being recovered, it would seem probable that by varying the rate of production and the back-pressure by the use of water, air, gas, or some other fluid to wash out the oil, or perhaps by some other means, the percentage of recovery can be greatly increased.

1 Unpublished notes.

2 Lewis, J. O., Methods for increasing the recovery from oil sands: U. S. Bur. Mines Bull. 148, 123 pp., 4 pIs., 1917. 
Capacity of wells.-The initial pumping capacity of the larger wells in Allen County fields is, as shown by the table on page 76 , generally between 25 and 100 barrels a day. A few have had greater yields and many smaller yields. A rather large number of wells report good showings but no commercial production. None of the wells drilled in recent years have flowed naturally. Because of inadequate marketing facilities, particularly the lack of a pipe line, the production may have been somewhat below the full capacity of the wells. Practically all the oil marketed is shipped by rail to refiners at Nashville and Louisville. Partly also on account of poor marketing facilities few of the wells have been shot.

If all the wells were to produce at their reported initial capacity for a year the output would be about $1,500,000$ barrels. To judge by wells elsewhere, the actual capacity of the field, if marketing facilities were excellent, would be about 500,000 barrels a year. The actual marketed production for 1917 was probably about 100,000 barrels.

\section{ORIGIN AND SOURCE OF THE OIL.}

The source and mode of formation of petroleum are not yet known with certainty, though fairly convincing evidence has been brought forth concerning the oil of certain fields. The most prevalent opinion among oil geologists is that it is of organic origin and that most of it at least has been derived from the remains of plants rather than of animals. However, the arguments for animal origin-as, for example, the fact that oil is in many places associated with mollusk shellshave appealed to many.

To the writers it seems very probable that most petroleum at least is of plant origin. The two principal reasons are, first, that carbonaceous remains of plants are far more abundant than those of animals in all rocks, and, second, that the hydrocarbon-bearing portions of animals decompose far more readily and quickly than such parts of plants.

By far the greater part (probably over 99 per cent) of the carbonaceous material in the earth's crust that can be classified with certainty is of plant origin, and, except for water, plants consist principally of the elements that go to make up petroleum and natural gas-carbon, hydrogen, and oxygen. The soft parts of animals also consist mainly of the same elements, together with more or less nitrogen, but they decompose or oxidize much more readily, and hence are much more likely to be lost in the air and surface water before being buried so deep that decomposition or oxidation ceases. Most oils contain a little nitrogen, which is a much more abundant and characteristic constituent of animal matter than of plant matter, but the amount in petroleum is generally a small fraction of 1 per cent. Many plants contain some nitrogen, and it appears possible that some of the nitro- 
gen in petroleum may have come from air buried with the organic mud, the oxygen having been used up in other combinations.

The fact that globules of petroleum have been observed in cavities associated with shells of sea animals does not seem significant, because petroleum is almost exclusively found in cavities or in the larger openings and pores of rocks, and it is much more reasonable to assume that the oil came from elsewhere and stopped where it found a cavity than to assume that a part of the flesh of a Paleozoic sea mollusk was converted into petroleum and the other products of the change were carried away while the petroleum was left for ages precisely where formed, particularly because, though fossils are abundant, occurrences of globules of oil in them are rare and are confined to those which happen to have cavities.

In Allen County fields a very large part of the carbonaceous material of the earth's crust is included in the black Chattanooga shale, which contains abundant remains of plants, particularly spore cases of ferns and related plants, which may be seen on almost any slab of shale. They form rather conspicuous black or dark-brown spots ranging from one thirty-second to one-eighth or even one-fourth inch in diameter and are commonly surrounded by resinous masses which are beyond a doubt derived from the ferns and yet are very similar in composition to petroleum. On the other hand, the remains of sea mollusks, particularly Lignula and Discina, are common. However, only the hard parts of these organisms are preserved, and there is fairly good reason for assuming that the soft parts, which alone could be transformed in part into petroleum, decayed before the mollusks were buried.

As this shale immediately overlies the oil-bearing rock, though in places it is separated from the "sand" by a few feet of light-colored clay shale; as it is by far the most carbonaceous bed in the region; and as petroleum heavier than that in the oil sand can be distilled from it this shale seems in all probability to have been the source of the oil now being produced in this and other parts of Kentucky. The writers know of no oil field where the circumstantial evidence as to the source of oil is stronger than it is in the Irvine field. The spore cases themselves, which are beyond doubt of plant origin, have undergone a gradual slight rearrangement of their molecules that brings their composition close to that of petroleum, as is indicated when they are distilled in a closed tube. If a specimen of the shale containing them, or in fact any specimen of the shale, is put in a glass tube a few inches long and closed except for a small opening at one end, and the shale shaken down to the opposite end and this end heated over a hot flame, gas will issue from the opening at the other end and may be ignited, while a conspicuous ring of oil distilled from the shale will form on the inside of the tube. 
The conditions that determine whether oil or gas, which are composed of practically the same elements, and what variety of either, will be formed when the shale is subjected to pressure and heat are not yet fully understood, but David White, ${ }^{1}$ who has given much study to this subject, believes that' gas is more likely to predominate over oil where the pressure is greatest.

So far as now known, oil and gas may be formed in Nature's great underground laboratory from any accumulation of plant material, whether carbonaceous shale, which was originally a mud black with the remains of plants, or coal, which was once peat, nearly free from mud.

\section{MODE OF ACCUMULATION OF THE OIL.}

The next problem is to trace the oil from its original position of wide dissemination in the shale to the oil "sand" and to portions of the oil "sand" where the structure is favorable for the accumulation and retention of pools. The Chattanooga shale, like most other geologic formations, was laid down in water, and its original thickness, when it was saturated with water, was much greater than its present thickness. When great deposits of mud, particularly carbonaceous mud, are buried beneath hundreds or thousands of feet of later deposits and allowed to lie thus buried for thousands or millions of years, they must obviously be greatly compacted by the pressure. The average carbonaceous mud that is not yet buried seems to have eight to ten times as much pore space as the Chattanooga shale. In the compacting process all the fluids contained in the mud which later became the Chattanooga shale were forced out by the most available route, whether that was downward, upward, or toward the sides. This process has recently been discussed by Johnson. ${ }^{2}$

It is worthy of note that in carbonaceous materials of recent origin showings of oil are extremely rare, even in portions that have been considerably compacted, which seems to indicate that the formation of petroleum does not begin until after most of the compacting has been accomplished, especially as throughout the world regions which contain much carbonaceous rock that is not greatly metamorphosed usually contain oil. If any oil is formed early in the history of a deposit it may be carried out in whatever direction the original water is forced out.

After most of the compacting had been accomplished, the fluids contained in the Chattanooga shale and the overlying and underlying formations were shifted about a little from time to time by any

1 Some relations in origin between coal and petroleum: Washington Acad. Sci. Jour., vol. 5, pp. 189-212, 1915.

2 Johnson, R. H., The rôle and fate of the connate water in oil and gas sands: Am. Inst. Min. Eng. Trans., vol. 51, pp. 587-610, 1916 . 
further compacting that took place, by crusted movements of the earth, by changes in internal temperature, by tidal stresses, by changes in air pressure, and probably by the extremely slow direct or indirect downward migration of all water in lands that have any considerable altitude above the sea. In this way the oil and gas formed in the Chattanooga shale were very likely shifted somewhat, though their evident close confinement and the existence of salt water near the surface indicate that the migration of none of the fluids has been extensive.

According to the writers' view, the migration and separation of the oil, gas, and water are effected as follows:

The water, oil, and gas in all rocks are constantly under the influence of intermolecular attractions, which are effective through only minute distances but which within those distances are very great, much exceeding that between the earth and a molecule. Such forces differ from substance to substance, and their general effect in an oil sand is to push the oil into the larger pores or cavities, or at least to retain it in such places after it has arrived. Apparently the heat activity of the molecules would not profoundly modify the result. The largest pores available to the oil of the Allen County fields are in the "Corniferous" and Silurian limestones. As the amount of oil was insufficient to fill all the cavities in the limestones throughout their extent, the continuance of all. the processes that tend to shift about fluids within the earth might very reasonably have caused the oil and gas to respond to the force of gravity, which is stronger for water than for oil, and to migrate to the places where the sand lay highest, leaving the water in the lower places. As Munn ${ }^{1}$ has pointed out, it seems impossible that in the nearly flat-lying beds of most oil fields the migration to the top of an anticline or other favorable structural feature could be accomplished by gravity alone while all the fluids were quiescent and the oil and gas in small globules, but if the fluids were moved any considerable distance the oil and gas might, during their migration, accommodate themselves to gravity and get to the tops of the anticlines, and if all the fluids were subject to an oscillatory motion, even if so slight as to amount to the diameter of only a few pores, the oil and gas would perhaps still migrate to the tops of the anticlines. Further, if a pool of oil were formed at the bottom of a syncline it might be buoyed bodily though very slowly to the top of a near-by anticline.

1 Munn, M. J., The anticlinal and hydraulic theories of oil and gas accumulation: Econ. Geology, vol. 4, pp. 509-539, 1909. 


\section{SURFACE INDICATIONS OF OIL AND GAS IN ALLEN AND ADJOINING COUNTIES.}

In order to reduce the cost of searching for new pools, it is highly important to learn what indications of petroleum existed at the surface in each field when petroleum was discovered. In the Allen County region the most important surface indications seem to have been the oil seepages. The structure in the North Petroleum and Rodemer pools, and perhaps also in the Wildwood pool, is such as would probably have led to recommending those areas if it had been carefully determined in advance of drilling. The structural features are, however, so obscure that a careful instrumental survey would have been necessary to determine their form and to constitute a foundation for drilling recommendations of any value. The development of the field could have been carried on with a much better knowledge of the chances of finding oil and would have been more rapid and less costly if the facts concerning the structure had been fully known and used. On the other hand, most pools do not conform closely to the structure, and hence sooner or later whether or not geologic data are used, the unpromising spots will be tested.

Gas and salt water are said to have been found in wells drilled for water at various places in the region, and such occurrences seem to be much more common in oil fields than elsewhere. The occurrence of showings of gas, oil, and salt water seems to indicate a lack of free circulation of ground water and hence conditions favorable to the retention of reservoirs of oil and gas. As many rocks were formed in the sea or have been below the bottom of the sea, they must have once contained salt water, and if they are very porous, or have cracks so that the water in the ground can circulate freely, the salt water and any oil and gas that are formed may be washed out. For this reason it seems probable to the writers that in regions where sand is unusually abundant oil and gas pools are much less likely to be found than where clay, shale, or other impervious rocks are relatively common.

Although no asphaltic rock has been found in the oil fields proper, the occurrence of extensive deposits of this nature in the northern part of Barren County and elsewhere must be regarded as a strong suggestion of oil in the general region. The asphalt of most asphaltic rock is no doubt the residue of an oil pool and is an indication that the oil of that pool has been largely dissipated. As a general rule, at least, this dissipation is due to evaporation, though some increase in asphaltic nature is due to chemical change, principally through the combination of portions of the oil with sulphur or oxygen. The occurrence of asphalt at the surface may indicate that a pool has migrated directly upward and escaped, and if so, particularly if the asphalt is on a favorable piece of structure, other oil pools may occur in under- 
lying sands not having communication with the surface. A second possibility is that the oil may have migrated up the dip of the oilbearing bed to its outcrop and there gradually escaped, evaporated, and oxidized. If so, the associated pools which have not escaped would be found some distance away from the asphalt. A third possibility is that the surface has been lowered to the oil pool by erosion, for this process is in constant operation on all lands, and has in many places lowered the surface thousands of feet. When an outcrop of asphaltic rock or asphalt seepage is found, it is desirable to first determine the structure and stratigraphy, and if it is found favorable then to drill at or near the occurrence of asphalt. If, however, the structure is found to be unfavorable, it may be best to hunt for favorable structural features in the general vicinity, more especially as near the surface water is commonly absent from the pores of rock, and the oil may have a chance to migrate down the dip to a syncline. Or if the stratigraphy is such as to make it seem improbable that any large-pored rock lies within reach of the drill it may not be worth while to drill at all.

\section{SUGGESTIONS FOR PROSPECTING.}

Favorable structural conditions.- The conclusion has been reached in foregoing sections of this report that the location of oil pools in Allen and adjacent counties has been determined by two factorsthe structure and the nature of the pore space of the oil-bearing formations. The limestones beneath the black shale are not everywhere sufficiently porous and open to serve as reservoirs for oil or gas. A small patch of porous rock in the "Corniferous" limestone, for example, entirely surrounded by dense, firm, impervious portions of the same formation, might contain an oil pool, even though it were at the bottom of a syncline or structural basin. On the other hand, the tendency of oil to migrate to higher levels and rise toward the summit of an anticline or dome when water is available to fill the pores vacated by it will result in the accumulation of oil in structurally favorable localities wherever possible. The conclusion is entirely justifiable, both from theoretical grounds and from the study of known conditions in the Allen County fields, that in this region, as in most other oil fields, there is much more likelihood of discovering new pools in localities where the structure is anticlinal than elsewhere. The search for new fields will therefore be expedited by a knowledge of the areas where anticlines or domes are known to be present and by suggestions which may help in deciphering the structure of regions which have not been examined in detail. Likewise the present producing fields may be most economically extended if the structural conditions there found are considered.

Known areas of favorable structure.-The more important anticlinal areas in Allen County, as far as known at the present time, are de- 
scribed in detail elsewhere in this report (pp. 67-69). In addition to the domes underlying the producing fields there are several untested anticlines in Allen County, some of which will quite likely be found to contain valuable reservoirs of oil. The most pronounced dome in the neighborhood of Scottsville trends east-northeast from Petroleum and is traversed by Trammel Fork below the mouth of Rough Creek. Test wells should be drilled on and near its crest, which is 4,300 feet east and 1,200 feet south of the south end of the railroad bridge crossing Trammel Fork. The anticline lies in the main southwest of Trammel Fork but extends across the valley flat into the V. Brown farm.

Another anticline which should be tested for oil is crossed by Rough Creek a mile and a quarter upstream from the Burd Miller wells. Its axis probably runs northeast and southwest. Prospecting may be quickly and cheaply accomplished by drilling in the valley flat where the depth to the oil-bearing formations is less than a hundred feet.

A third and less pronounced dome lies west and northwest of Adolphus. The best location for test holes appears to be threequarters of a mile due northwest of the Adolphus station.

On the other hand, the Trammel anticline, crossing Trammel Fork south of the mouth of Snake Creek, in all probability contains no oil. The stream has cut well below the base of the black shale into the underlying "Corniferous" limestone, giving ample opportunity for the escape of any oil which may have previously been present beneath the impervious shale. For the same reason the presence of oil in limestones immediately underlying the black shale is very improbable in the neighborhood of Long Creek or of Barren River above the mouth of Walnut Creek.

Search for other areas of favorable structure.-Because of the strong influence exerted upon the location of oil reservoirs by the composition and porosity of the oil-bearing formations, prospecting in synclinal areas or in regions where the beds display the prevailing gentle northwest dip should not be discouraged. Nevertheless, there is no question but that detailed geologic examination to determine structural relations should precede drilling operations if the oil pools of Allen County are to be economically and promptly developed. The presence of several anticlines in the small portion of the county which was examined in detail is in itself good evidence of the presence of similar structural features in other parts of the county. Wells drilled near the summits of these domes will have much better chances of tapping productive reservoirs of oil than those drilled promiscuously without reference to structure.

Although there are no conspicuous massive limestone beds which may be traced over extensive areas, the lithologic character of the Mississippian strata is such that the position of the beds may be accu- 


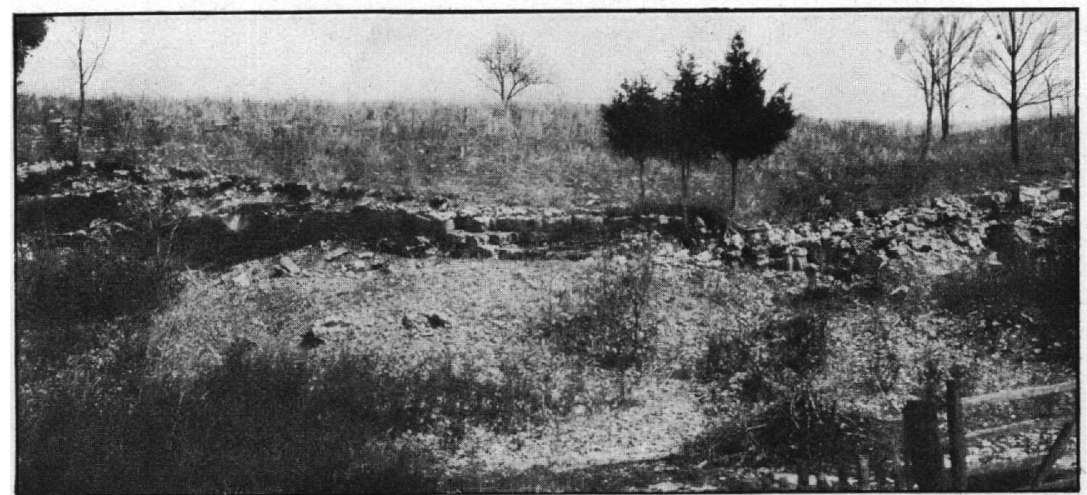

A. ST. LOUIS LIMESTONE EXPOSURE WITH TWO PSEUDO-ANTICLINES NEAR WELLS SHOWING A LITTLE GAS, ON SCOTTSVILLE-BOWLING GREEN PIKE AT CROSSING OF DRAKE CREEK.

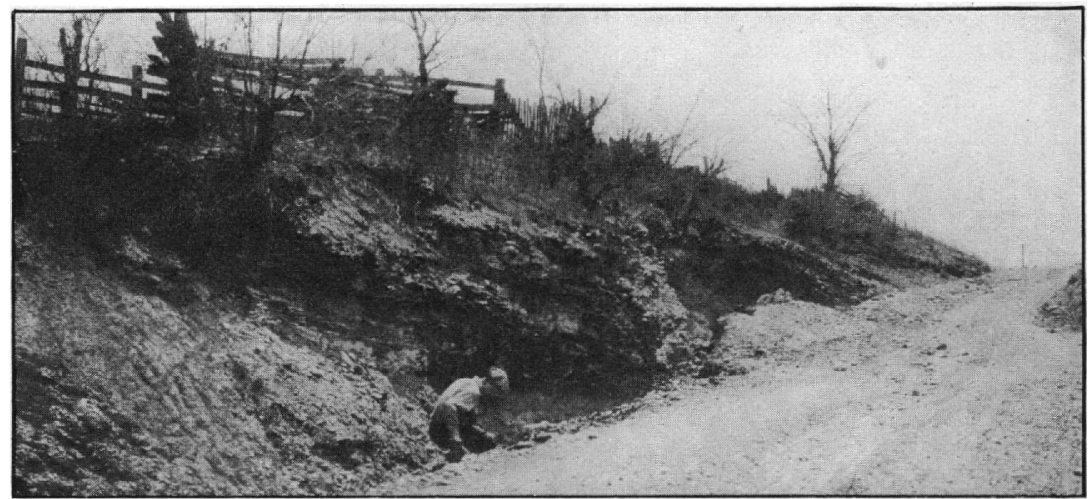

13. PSEUDO-ANTICLINES, SYNCLINES, AND FAULTS IN UPPERMOST PART OF BLACK CIIATTANOOGA SHALE AND OVERLYING BEDS OUTCROPPING ON EAST VALLEY SIDE OF LONG CREEK NEAR HOLLAND, KY.

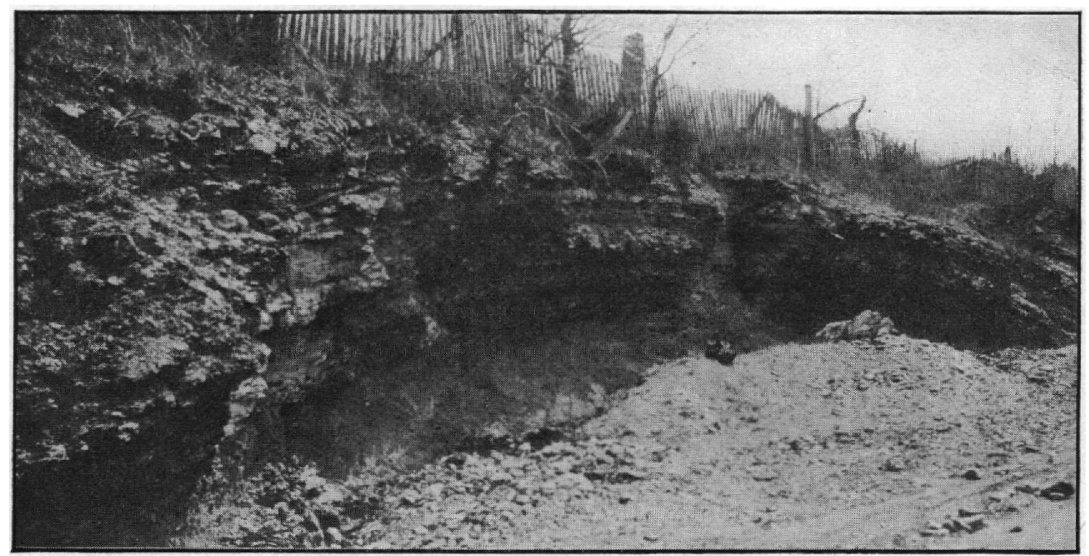

C. NEAR VIEW OF ONE OF THE PSEUDO-ANTICLINES OF PRECEDING VIEW.

\section{STRUCTURAL FEATURES DEVELOPED THROUGH EROSION AND SLUMPING AND OF NO VALUE IN FINDING OIL.}



rately determined in most parts of Allen County. The fossiliferous beds at the base of the Warsaw, the sheeted chert zone near the top of the Fort Payne, and the Pentremites-bearing limestone at the base of the St. Louis formation may be traced for long distances and serve as "key" rocks wherever they are present. On the other hand, the determination of structure in the basal Mississippian beds is a matter of considerable difficulty if not altogether impossible. The false bedding of these limestones is especially deceptive and may easily be mistaken for tilting. (See PI. IV, p. 47.)

In many localities removal of the more soluble limestones by the action of underground water has permitted the overlying beds to settle. More massive strata above shaly zones have slumped a few feet downhill in many places. The exposure that results from either process may closely simulate the ordinary hillside exposure of gently tilted beds and may be misinterpreted to indicate the dip of the formations. (See Pl.IX.)

Extension of producing fields.--Extension of each of the three producing oil fields is favored by the structural conditions, although it is not possible to outline the extent of the Wildwood pool at the present stage in its development. If the structural conditions in the Rodemer pool are taken as the criterion, that pool may be farther extended only toward the southwest. Favorable localities for drilling are in the west part of the A. M. Holson farm, the southeast corner of the Denton Reeves farm, and on the Martha Keen farm for some distance southwest of wells Nos. 13 and 14. Extension of the North Petroleum pool toward the northeast is more likely than in any other direction. Wells should be drilled on the M. B. Crowe farm east and northeast from wells Nos. 5 and 8.

Deeper oil sands.-Attention has been called to the fact that the Silurian limestone, the upper surface of which is probably at a depth of 50 to 70 feet below the bottom of the black shale throughout the greater part of Allen County, is lithologically better adapted to serve as an oil reservoir than is the overlying "Corniferous" limestone. No hole anywhere in the county, therefore, should be abandoned until the drill has penetrated to a depth of at least 150 feet below the base of the black shale, nor should it be abandoned until it has been shot. Failure to find oil at a depth of 10 to 50 feet below the shale-the position of the sund in most of the producing wells-does not preclude the presence of an oil reservoir at 100 or 130 feet below the shale-the position of the "big pay" in the Crowe well No. 7 and the Mantle well No. 3.

On the other hand, the chances of obtaining oil at still greater depths do not seem to be very favorable. At least a dozen holes in and near Allen County have penetrated the Ordovician limestones commonly called "Trenton," and none have so far proved successful. It is probably true, however, that none of these tests have been made 
where structural conditions favored the accumulation of oil or gas in that formation. A more accurate determination of the possibilities of these limestones, or any other deep formation, could be obtained by drilling the Frost well No. 18 on the Rodemer dome or the Crowe well No. 7 on the North Petroleum anticline to a depth of 1,000 to 1,200 feet.

\section{PRODUCTION OF OIL.}

The production of oil in the Allen County fields is not known with any degree of exactness, but it has probably not been more than 100,000 barrels.

The number of wells drilled by month, the percentage of successful wells, and the average initial production of successful wells are shown in the following table, which is made up from figures published in the Oil and Gas Journal:

Oil wells in Allen County, Ky.

\begin{tabular}{|c|c|c|c|c|}
\hline & $\begin{array}{l}\text { Number } \\
\text { of wells } \\
\text { drilled. }\end{array}$ & $\begin{array}{c}\text { Number of } \\
\text { successful } \\
\text { wells. } \\
\text {. }\end{array}$ & $\begin{array}{l}\text { Percentage } \\
\text { of produc- } \\
\text { tive wells. }\end{array}$ & $\begin{array}{c}\text { Average } \\
\text { initial pro- } \\
\text { duction of } \\
\text { productive } \\
\text { wells } \\
\text { (barrels } \\
\text { per day). }\end{array}$ \\
\hline 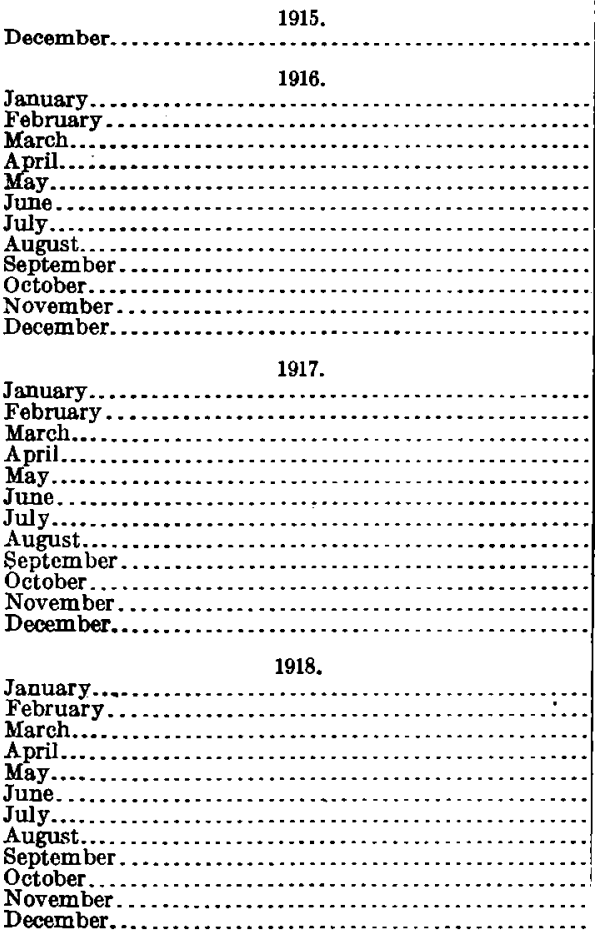 & $\begin{array}{r}2 \\
\\
2 \\
2 \\
7 \\
6 \\
12 \\
5 \\
29 \\
13 \\
26 \\
10 \\
10 \\
9 \\
\\
1 \\
19 \\
11 \\
5 \\
14 \\
25 \\
8 \\
13 \\
15 \\
14 \\
16 \\
12 \\
\\
9 \\
9 \\
15 \\
21 \\
11 \\
10 \\
13 \\
24 \\
15 \\
41 \\
38 \\
19\end{array}$ & $\begin{array}{r}1 \\
\\
2 \\
2 \\
5 \\
6 \\
8 \\
5 \\
20 \\
12 \\
14 \\
10 \\
9 \\
8 \\
\\
0 \\
11 \\
4 \\
5 \\
8 \\
12 \\
5 \\
4 \\
13 \\
11 \\
6 \\
9 \\
9 \\
6 \\
11 \\
15 \\
10 \\
10 \\
11 \\
21 \\
13 \\
38 \\
33 \\
16\end{array}$ & $\begin{array}{r}57.9 \\
36.4 \\
100.0 \\
57.1 \\
48.0 \\
62.5 \\
30.7 \\
86.7 \\
78.6 \\
37.5 \\
75.0 \\
\\
\\
66.7 \\
100.0 \\
73.3 \\
71.4 \\
90.9 \\
100.0 \\
84.6 \\
87.5 \\
81.5 \\
92.7 \\
87.0 \\
84.2\end{array}$ & $\begin{array}{r}95.7 \\
68.7 \\
180.0 \\
37.2 \\
16.9 \\
26.0 \\
4.0 \\
11.7 \\
23.2 \\
11.7 \\
40.6 \\
\\
12.5 \\
27.8 \\
13.4 \\
16.0 \\
17.6 \\
17.8 \\
43.2 \\
35.2 \\
65.8 \\
18.8 \\
21.7 \\
81.4\end{array}$ \\
\hline 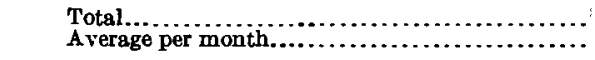 & $\begin{array}{r}511 \\
13.8\end{array}$ & $\begin{array}{l}334 \\
9.0\end{array}$ & $\begin{array}{c}\mathbf{7 5 . 0} \\
\ldots \ldots\end{array}$ & 40.4 \\
\hline
\end{tabular}


These figures show much variation, but the following general trends are discernible. The rate of drilling is increasing, except that it tends to fall during the winter. The percentage of successful wells and their initial production are very irregular but on the whole show neither general rise nor general decline.

\section{SHALE OIL.}

It is interesting, both for the scientific purpose of a better understanding of the origin of petroleum and the practical purpose of knowing what opportunity exists of making artificial petroleum from the Chattanooga shale, to know the nature and proportions of hydrocarbons which may be extracted from it. Shales from which oil may be obtained are common in the United States and other countries, and in some places, particularly in Scotland, the manufacture of petroleum from shale has been carried on for many years. Several plants built for the extraction of oil from the Chattanooga shale were in operation in Kentucky 50 or 60 years ago. ${ }^{1}$ Some of the petroleum carried in such rocks may be dissolved out with chloroform or some other liquid in which petroleum dissolves readily and some requires distillation; in other words, some seems to exist as petroleum in the shale, but a larger part is a chemical product of distillation of other hydrocarbons.

The character of the oil obtained from oil shale depends to a considerable extent on the heat and pressure used in the tests. Otherwise, an analysis of the resulting oil would be worth while for comparison with the oil in the sand below believed to have been derived from the black shale.

Samples of black shale from numerous places in Kentucky, Tennessee, Pennsylvania, Ohio, Indiana, and other States have been tested, and the results are discussed by G. H. Ashley, ${ }^{2}$ who remarks: "According to these figures, the Devonian black shale can be expected to yield not over 10 or 12 gallons of oil, 2,000 cubic feet of gas (as a by-product), and one-third of a pound of ammonia to the ton."

\section{NOTES ON DEVELOPMENT.}

Although this report is designed primarily to be purely geologic in nature, the geology of the field is so closely related to problems of the recovery of petroleum that a few brief notes seem needed.

As the sand lies not more than 200 feet below the valley bottoms, drilling is comparatively inexpensive. The average cost of wells is about $\$ 600$. Most of the drilling is done with machines, but derricks have been erected here and there, particularly for deep tests. The general appearance of the field differs markedly from those where the sand lies at great depth, for there is no forest of derricks but instead

1 Moore, P. J., oral communication.

2 Ashley, G. H., Oil resources of black shales of the eastern United States: U. S. Geol. Survey Bull. 641, p. 319, 1917. 
inconspicuous pumping jacks scattered through the woods and fields of a somewhat hilly region. . As the country is not very rough, it is generally easy to haul drilling machinery to any desired point, though here and there inexpensive temporary roads have been built. It is also not difficult to get a supply of water and fuel to the wells.

The connecting pores of the sand are relatively large throughout its extent, and the oil is under more or less pressure from gas. Hence the oil flows into the wells rapidly, and there is little need for close drilling. However, the sand does vary somewhat in porosity, and hence, there seems to be a possibility that small portions of the pool may be surrounded by advancing water and prevented from reaching a well.

The method of advance of this water is a geologic problem of great economic importance. As the oil is taken out, air, gas, or water must flow into the pores to take its place, and the question immediately arises, How complete is the replacement? If the walls of the pores retain a coating of oil the oil recovered may be much less than the original amount in the ground, for most of the pores are probably not over one five-hundredth of an inch in diameter and a thin coating on their walls would mean a large part of their original content. It may be that replacement is more complete with slow extraction, so that the percentage of recovery would be higher if the oil were taken out at a slower rate.

So far few wells have been shot and none flow. Partly because of insufficient marketing facilities, there has been no effort to force wells to their full capacity. As these facilities grow better and the demand for oil increases, and as the production of individual wells declines, no doubt many of them will be shot and thus rejuvenated.

\section{WELI RECORDS.}

The following table gives the records of some of the wells in Allen County.

Records of wells in Allen County, Ky.

Barlow well No. 1.

\begin{tabular}{|c|c|c|c|c|c|c|}
\hline \multirow{2}{*}{$\begin{array}{l}\text { Owner or source } \\
\text { of information. }\end{array}$} & \multirow{2}{*}{ Location. } & \multirow{2}{*}{$\begin{array}{l}\text { Alti- } \\
\text { tude. }\end{array}$} & \multicolumn{3}{|c|}{ Driller's log. } & \multirow{2}{*}{ Remarks } \\
\hline & & & Formation. & $\begin{array}{c}\text { Thick- } \\
\text { ness. }\end{array}$ & Depth. & \\
\hline Mandale Oil Co... & $\begin{array}{l}\frac{1}{2} \text { mile south west of } \\
\text { Scottsville. }\end{array}$ & $\begin{array}{r}\text { Feet. } \\
609\end{array}$ & $\begin{array}{l}\text { Lime and shale.... } \\
\text { Black shale....... } \\
\text { Lime.............. } \\
\text { Oil sand.......... }\end{array}$ & $\begin{array}{r}\text { Feet. } \\
72 \\
47 \\
59 \\
30\end{array}$ & $\begin{array}{r}\text { Feet. } \\
72 \\
119 \\
178 \\
208\end{array}$ & \\
\hline
\end{tabular}

Boucher well No. 1.

\begin{tabular}{|c|c|c|c|c|c|c|}
\hline $\begin{array}{l}\text { White Plains Oil } \\
\text { \& Gas Co. }\end{array}$ & $\begin{array}{l}5 \text { miles northwest } \\
\text { of Scottsville. }\end{array}$ & & $\begin{array}{l}\text { Surface............. } \\
\text { Lime............. } \\
\text { Rlack shale...... } \\
\text { Lime and sand... }\end{array}$ & $\begin{array}{r}22 \\
256 \\
47 \\
128\end{array}$ & $\begin{array}{r}22 \\
278 \\
325 \\
453\end{array}$ & Hole dry; plugged. \\
\hline
\end{tabular}


Records of wells in Allen County, Ky.-Continued.

Bryley well No. 1.

\begin{tabular}{|c|c|c|c|c|c|c|}
\hline \multirow{2}{*}{$\begin{array}{l}\text { Owner or source } \\
\text { of information. }\end{array}$} & \multirow{2}{*}{ Location. } & \multirow{2}{*}{$\begin{array}{l}\text { Alti- } \\
\text { tude. }\end{array}$} & \multicolumn{3}{|c|}{ Driller's log. } & \multirow{2}{*}{ Remarks. } \\
\hline & & & Formation. & $\begin{array}{l}\text { Thick- } \\
\text { ness. }\end{array}$ & Depth. & \\
\hline $\begin{array}{l}\text { White Plains Oil } \\
\text { \& Gas Co. }\end{array}$ & $\begin{array}{l}3 \text { miles northwest } \\
\text { of Scottsville. }\end{array}$ & $\begin{array}{c}\text { Feet. } \\
\ldots \ldots\end{array}$ & $\begin{array}{l}\text { Surface............ } \\
\text { Lime........... } \\
\text { Black shale..... } \\
\text { Iime and sand... }\end{array}$ & $\begin{array}{r}\text { Feet. } \\
22 \\
290 \\
42 \\
64\end{array}$ & \begin{tabular}{r|} 
Feet. \\
22 \\
312 \\
354 \\
418
\end{tabular} & $\begin{array}{l}\text { Hole dry; drilled } \\
\text { through "sand" } \\
\text { and stopped in } \\
\text { "white shale" } \\
\text { which probably } \\
\text { represents the } \\
\text { break between } \\
\text { "Cornif e o o s" } \\
\text { and Silurian } \\
\text { limestones. }\end{array}$ \\
\hline
\end{tabular}

Burton well No. 1.

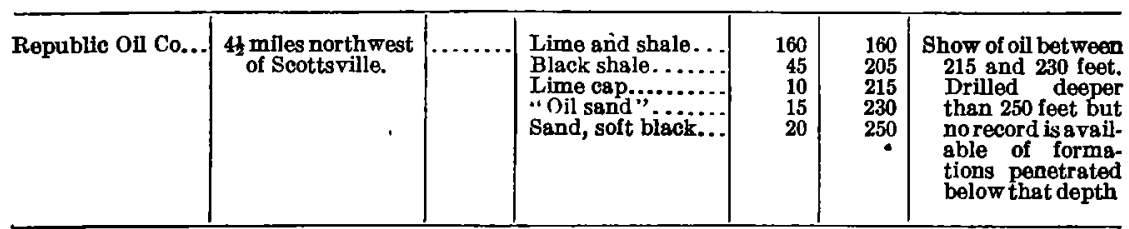

Carver well No. 1.

\begin{tabular}{|c|c|c|c|c|c|c|}
\hline $\begin{array}{l}\text { White Plains Oil } \\
\text { \& Gas Co. }\end{array}$ & Wildwood pool.... & 768 & 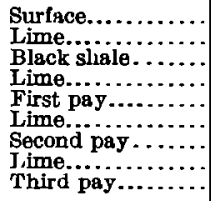 & $\begin{array}{r}20 \\
175 \\
44 \\
47 \\
4 \\
10 \\
10 \\
7 \\
15\end{array}$ & $\begin{array}{r}20 \\
195 \\
239 \\
286 \\
290 \\
300 \\
310 \\
317 \\
332\end{array}$ & $\begin{array}{l}\text { Completed Apr. 15, } \\
\text { 1917. Actual pro } \\
\text { duction first 24 } \\
\text { hours, } 130 \text { barrels. }\end{array}$ \\
\hline
\end{tabular}

Carver well No. 2.

\begin{tabular}{|c|c|c|c|c|c|c|}
\hline $\begin{array}{l}\text { White Plains Oil } \\
\text { \& Gas Co. }\end{array}$ & $\begin{array}{l}200 \text { feet esst of } \\
\text { Carver well No. } 1 .\end{array}$ & 764 & 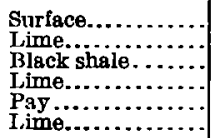 & $\begin{array}{r}23 \\
168 \\
45 \\
47 \\
15 \\
25\end{array}$ & $\begin{array}{r}23 \\
191 \\
236 \\
283 \\
298 \\
323\end{array}$ & $\begin{array}{l}\text { Completed May 1, } \\
1917 \text {. Shot be- } \\
\text { tween } 283 \text { and } 298 \\
\text { feet. Production } \\
\text { small. }\end{array}$ \\
\hline
\end{tabular}

Cherry well No. 2.

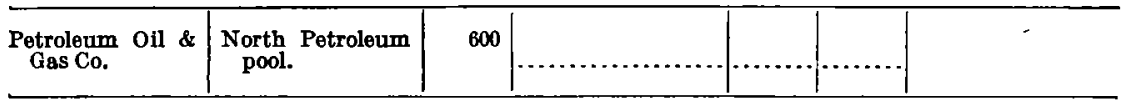

Cherry well No. 3.

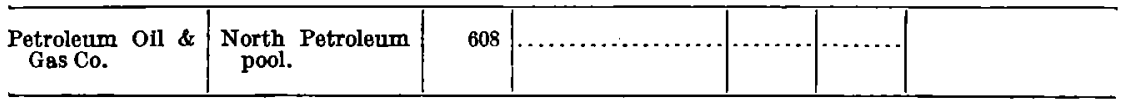

Cherry well No. 4.

\begin{tabular}{l|l|r|l|r|r|r}
\hline $\begin{array}{l}\text { Petroleum Oil \& } \\
\text { Gas Co. }\end{array}$ & $\begin{array}{l}\text { North Petroleum } \\
\text { pool. }\end{array}$ & 638 & $\begin{array}{l}\text { Lime and shale.... } \\
\text { Black shale....... }\end{array}$ & $\begin{array}{r}60 \\
40\end{array}$ & $\begin{array}{r}60 \\
100\end{array}$ & $\begin{array}{c}\text { Drilling, Apr. 26, } \\
\text { 1917, a few eet un- } \\
\text { der black shale. }\end{array}$ \\
\hline
\end{tabular}


Records of wells in Allen County, Ky.-Continued.

Crowe well No. 1.

\begin{tabular}{|c|c|c|c|c|c|c|}
\hline \multirow{2}{*}{$\begin{array}{l}\text { Owner or source } \\
\text { of information. }\end{array}$} & \multirow{2}{*}{ Location. } & \multirow{2}{*}{$\begin{array}{l}\text { Alti- } \\
\text { tude. }\end{array}$} & \multicolumn{3}{|c|}{ Driller's log. } & \multirow{2}{*}{ Remarks. } \\
\hline & & & Formation. & $\begin{array}{l}\text { Thick- } \\
\text { ness. }\end{array}$ & Depth. & \\
\hline $\begin{array}{l}\text { White Plains Oil } \\
\text { \& Gas Co. }\end{array}$ & $\begin{array}{l}\text { North Petroleum } \\
\text { pool. }\end{array}$ & $\begin{array}{l}\text { Feet. } \\
606\end{array}$ & ‘ & $\begin{array}{l}\text { Feet. } \\
\text { Fe. }\end{array}$ & Feet. & $\begin{array}{l}\text { Reported initial } \\
\text { production, } 25 \\
\text { barrels. }\end{array}$ \\
\hline
\end{tabular}

Crowe well No. 2.

\begin{tabular}{|c|c|c|c|c|c|c|}
\hline $\begin{array}{l}\text { White Plains Oil } \\
\text { \& Gas Co. }\end{array}$ & $\begin{array}{l}\text { North Petroleum } \\
\text { pool. }\end{array}$ & 611 & 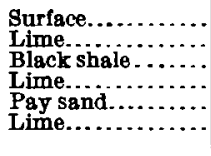 & $\begin{array}{r}8 \\
33 \\
22 \\
35 \\
21 \\
6\end{array}$ & $\begin{array}{r}8 \\
41 \\
63 \\
98 \\
122 \\
12 j\end{array}$ & $\begin{array}{l}\text { Reported initial } \\
\text { production, } 50 \\
\text { barrels. }\end{array}$ \\
\hline
\end{tabular}

Crowe well No. 3.

\begin{tabular}{|c|c|c|c|c|c|}
\hline $\begin{array}{l}\text { White Plains Oil } \\
\text { \& Gas Co. }\end{array}$ & $\begin{array}{l}\text { North Petroleum } \\
\text { pool. }\end{array}$ & 656 & 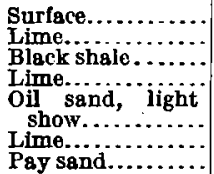 & $\begin{array}{r}11 \\
59 \\
40 \\
36 \\
\\
4 \\
23 \\
17\end{array}$ & $\begin{array}{r}11 \\
70 \\
110 \\
146 \\
150 \\
173 \\
190\end{array}$ \\
\hline
\end{tabular}

Crowe well No. 4.

\begin{tabular}{|c|c|c|c|c|c|c|}
\hline $\begin{array}{l}\text { White Plains Oil } \\
\text { \& Gas Co. }\end{array}$ & $\begin{array}{l}\text { North Petroleum } \\
\text { pool. }\end{array}$ & 647 & 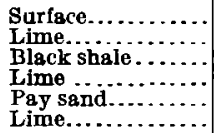 & $\begin{array}{r}15 \\
44 \\
37 \\
65 \\
12 \\
7\end{array}$ & $\begin{array}{r}15 \\
59 \\
96 \\
161 \\
173 \\
180\end{array}$ & $\begin{array}{l}\text { Fresh water in } \\
\text { black shale at } 90 \\
\text { feet. Reported } \\
\text { production, } 30 \\
\text { barrels. }\end{array}$ \\
\hline
\end{tabular}

Crowe well No. 5.

\begin{tabular}{|c|c|c|c|c|c|c|}
\hline $\begin{array}{l}\text { White Plains Oil } \\
\text { \& Gas Co. }\end{array}$ & $\begin{array}{l}\text { North Petroleum } \\
\text { pool. }\end{array}$ & $\cdots$ & $\begin{array}{l}\text { Surface........... } \\
\text { Lime.... } \\
\text { Black shale } . . . . . . \\
\text { Lime and shale... }\end{array}$ & $\begin{array}{r}8 \\
14 \\
43 \\
88\end{array}$ & $\begin{array}{r}8 \\
22 \\
65 \\
153\end{array}$ & $\begin{array}{l}\text { Very light show of } \\
\text { of between } 137 \\
\text { and } 143 \text { feet. }\end{array}$ \\
\hline
\end{tabular}

Crowe well No. 6.

\begin{tabular}{|c|c|c|c|c|c|c|}
\hline $\begin{array}{l}\text { White Plains Oil } \\
\text { \& Gas Co. }\end{array}$ & $\begin{array}{l}\text { North Petroleum } \\
\text { pool. }\end{array}$ & 711 & 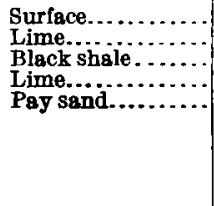 & $\begin{array}{r}34 \\
83 \\
38 \\
20 \\
6\end{array}$ & $\begin{array}{r}34 \\
127 \\
165 \\
185 \\
191\end{array}$ & $\begin{array}{l}\text { "Just a show" of } \\
\text { water at } 191 \text { feet. } \\
\text { Later drilled } \\
\text { deeper to } 212 \text { feet } \\
\text { but no record } \\
\text { available. Re- } \\
\text { ported in it i a } \\
\text { product ion } 40 \\
\text { barrels. }\end{array}$ \\
\hline
\end{tabular}

Crowe well No. 7 .

\begin{tabular}{|c|c|c|c|c|c|c|}
\hline $\begin{array}{l}\text { White Plains Oil } \\
\text { \& Gas Co. }\end{array}$ & $\cdots \ldots \ldots \ldots \ldots \ldots$ & 695 & 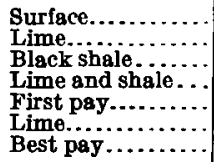 & $\begin{array}{r}9 \\
91 \\
43 \\
85 \\
5 \\
40 \\
18\end{array}$ & $\begin{array}{r}9 \\
100 \\
143 \\
228 \\
233 \\
273 \\
291\end{array}$ & $\begin{array}{l}\text { Reported initial } \\
\text { production, } 100 \\
\text { barrels. }\end{array}$ \\
\hline
\end{tabular}


Records of wells in Allen County, Ky.-Continued.

Crowe well No. 8.

\begin{tabular}{|c|c|c|c|c|c|c|}
\hline \multirow{2}{*}{$\begin{array}{l}\text { Owner or source } \\
\text { of information. }\end{array}$} & \multirow{2}{*}{ Location. } & \multirow{2}{*}{$\begin{array}{l}\text { Alti- } \\
\text { tude. }\end{array}$} & \multicolumn{3}{|c|}{ Driller's log. } & \multirow{2}{*}{ - Remarks. } \\
\hline & & & Formation. & $\begin{array}{l}\text { Thick- } \\
\text { ness. }\end{array}$ & Depth. & \\
\hline $\begin{array}{l}\text { White Plains Oil } \\
\& \text { Gas Co. }\end{array}$ & & Feet. & $\begin{array}{l}\text { Surface........... } \\
\text { Lime............ } \\
\text { Black shale...... } \\
\text { Lime and sand.... }\end{array}$ & $\begin{array}{r}\text { Feet. } \\
12 \\
98 \\
31 \\
216\end{array}$ & $\begin{array}{r}\text { Feet. } \\
12 \\
110 \\
144 \\
360\end{array}$ & $\begin{array}{l}2 \text { bailers of water at } \\
310 \text { foet. Showed } \\
\text { one-half bailer of } \\
\text { oil overnight. }\end{array}$ \\
\hline
\end{tabular}

Fishburn well No. 1.

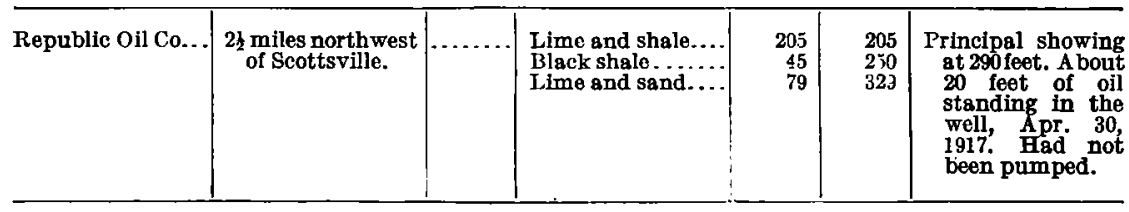

Fishburn well No. 2.

\begin{tabular}{|c|c|c|c|c|c|c|}
\hline Republic Oil Co... & $\begin{array}{l}2 \text { miles northwest } \\
\text { of Scottsville. }\end{array}$ & $\ldots \ldots \ldots$ & $\begin{array}{l}\text { Lime and shale.... } \\
\text { Black shale....... } \\
\text { Cap rock....... } \\
\text { Oil sand. } \\
\text { Lime, dark......... }\end{array}$ & $\begin{array}{r}310 \\
48 \\
4 \\
13 \\
25\end{array}$ & $\begin{array}{l}310 \\
358 \\
362 \\
375 \\
400\end{array}$ & Dry hole. \\
\hline
\end{tabular}

Fisher well No. 1.

\begin{tabular}{|c|c|c|c|c|c|c|}
\hline Ocala Oil Co..... & Wildwood pool.... & 781 & $\begin{array}{l}\text { Lime and shale... } \\
\text { Black shale ...... } \\
\text { "Sand,"gray .... } \\
\text { Pay sand......... }\end{array}$ & $\begin{array}{r}225 \\
55 \\
53 \\
7\end{array}$ & $\begin{array}{l}225 \\
280 \\
333 \\
340\end{array}$ & $\because$ \\
\hline
\end{tabular}

Fisher well No. 2.

\begin{tabular}{|c|c|c|c|c|c|c|}
\hline Ocala Oil Co...... & $\begin{array}{l}200 \text { feet southeast } \\
\text { of well No. } 1 .\end{array}$ & 772 & 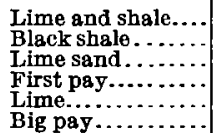 & $\begin{array}{r}210 \\
45 \\
45 \\
5 \\
9 \\
6\end{array}$ & $\begin{array}{l}\mathbf{2 1 0} \\
\mathbf{2 5 5} \\
\mathbf{3 0 0} \\
\mathbf{3 0 5} \\
\mathbf{3 1 4} \\
\mathbf{3 2 0}\end{array}$ & $\begin{array}{l}\text { Pumping } 40 \text { to } 50 \\
\text { berrels a day dur- } \\
\text { ing first week of } \\
\text { pr od u t i on, } \\
\text { about May 10, } \\
\text { 1917. }\end{array}$ \\
\hline
\end{tabular}

Fisher well No. 3.

\begin{tabular}{|c|c|c|c|c|c|}
\hline Ocala Oil Co...... & $\begin{array}{l}210 \text { feet south of } \\
\text { well No. } 1 .\end{array}$ & 770 & 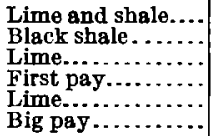 & $\begin{array}{r}205 \\
45 \\
55 \\
5 \\
4 \\
6\end{array}$ & $\begin{array}{l}205 \\
250 \\
305 \\
310 \\
314 \\
320\end{array}$ \\
\hline
\end{tabular}

Fisher well No. 4.

\begin{tabular}{|c|c|c|c|c|c|c|}
\hline Ocale Oil Co....... & $\begin{array}{l}180 \text { feet southeast } \\
\text { of well No. } 2 .\end{array}$ & 757 & 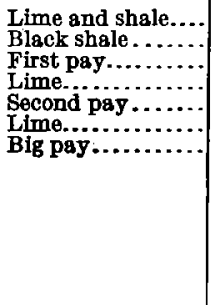 & $\begin{array}{r}193 \\
45 \\
6 \\
46 \\
4 \\
11 \\
15\end{array}$ & $\begin{array}{l}193 \\
238 \\
244 \\
290 \\
294 \\
305 \\
320\end{array}$ & $\begin{array}{l}\text { The big pay is a } \\
\text { br ow s s nd } \\
\text { which gave only } \\
\text { a smsll show at } \\
\text { first. Driled } \\
\text { into a water sand } \\
\text { and t opped; } \\
\text { bailed well; over- } \\
\text { night } 100 \text { feet of } \\
\text { oil collected in } \\
\text { well from the } \\
\text { brown s a n d. } \\
\text { Will pump } 10 \text { to } \\
20 \text { barrels. }\end{array}$ \\
\hline
\end{tabular}


Records of wells in Allen County, Ky.-Continued.

Fisher well No. 5.

\begin{tabular}{|c|c|c|c|c|c|c|}
\hline \multirow{2}{*}{$\begin{array}{l}\text { Owner or source, } \\
\text { of information. }\end{array}$} & \multirow{2}{*}{ Location. } & \multirow{2}{*}{$\begin{array}{l}\text { Alti- } \\
\text { tude. }\end{array}$} & \multicolumn{3}{|c|}{ Driller's log. } & \multirow{2}{*}{ Remarks. } \\
\hline & & & Formation. & $\begin{array}{c}\text { Thick- } \\
\text { ness. }\end{array}$ & Depth. & \\
\hline Ocala Oil Co...... & $\begin{array}{l}1,100 \text { feet northeast } \\
\text { of well No. } 2 .\end{array}$ & Feet. & $\begin{array}{l}\text { Lime and shale.... } \\
\text { Black shale... . . . } \\
\text { Sand, brown ..... } \\
\text { Lime, dark....... } \\
\text { Lime............. }\end{array}$ & $\begin{array}{r}\text { Feet. } \\
188 \\
45 \\
5 \\
15 \\
97\end{array}$ & $\begin{array}{r}\text { Feet. } \\
188 \\
233 \\
238 \\
253 \\
350\end{array}$ & $\begin{array}{l}\text { Strong flow of salt } \\
\text { water at bottom } \\
\text { of well. No oil. }\end{array}$ \\
\hline
\end{tabular}

Fisher well No. 6.

\begin{tabular}{|c|c|c|c|c|c|c|}
\hline Ocala Oil Co. ..... & $\ldots \ldots \ldots \ldots \ldots \ldots$ & 745 & $\ldots \ldots \ldots \ldots \ldots \ldots+$ & $\ldots \ldots$ & $\ldots \ldots \ldots$ & $\begin{array}{l}\text { Commenced drill- } \\
\text { ing May 1, } 1917 .\end{array}$ \\
\hline
\end{tabular}

J. W. Frost well No. 1.

\begin{tabular}{|c|c|c|c|c|c|c|}
\hline $\begin{array}{l}\text { White Plains Oil } \\
\text { \& Gas Co. }\end{array}$ & $\begin{array}{l}\text { Southeast margin } \\
\text { of Rodemer pool. }\end{array}$ & & $\begin{array}{l}\text { Lime.............. } \\
\text { Black shale } . . . . \\
\text { Lime, sandy ..... }\end{array}$ & $\begin{array}{r}169 \\
41 \\
55\end{array}$ & $\begin{array}{l}169 \\
210 \\
265\end{array}$ & $\begin{array}{l}\text { Flow of water at } \\
285 \text { feet. } \\
\text { plugged. }\end{array}$ \\
\hline
\end{tabular}

J. W. Frost well No. 2.

\begin{tabular}{|c|c|c|c|c|c|c|}
\hline $\begin{array}{l}\text { White Plains Oil } \\
\text { \& Gas Co. }\end{array}$ & $\begin{array}{l}\text { Northwest margin } \\
\text { of Wildwood } \\
\text { pool. }\end{array}$ & $\cdots$ & 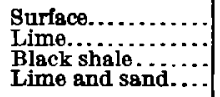 & $\begin{array}{r}18 \\
246 \\
46 \\
73\end{array}$ & $\begin{array}{r}18 \\
264 \\
310 \\
383\end{array}$ & Hole dry. \\
\hline
\end{tabular}

J. W. Frost well No. 3.

\begin{tabular}{|c|c|c|c|c|c|c|}
\hline $\begin{array}{l}\text { White Plains Oil } \\
\text { \& Gas Co. }\end{array}$ & $\begin{array}{l}\text { Northeast margin } \\
\text { of Rodemer pool. }\end{array}$ & $\ldots \ldots$ & $\begin{array}{l}\text { Surface.......... } \\
\text { Lime } \\
\text { Black shile } \ldots . . . \\
\text { Sandy lime........ }\end{array}$ & $\begin{array}{r}14 \\
218 \\
45 \\
108\end{array}$ & $\begin{array}{r}14 \\
2 \backslash 2 \\
277 \\
385\end{array}$ & $\begin{array}{l}\text { No oil. Flow of } \\
\text { water at } 375 \text { feet. }\end{array}$ \\
\hline
\end{tabular}

V. A. Frost well No. 1.

\begin{tabular}{l|r|r|r|r|r|r}
\hline White Plains oil & Rodemer pool..... & $\ldots . . . .$. & Unrecorded ........ & 156 & 156 \\
\& Gas Co. & & & First sand......... & 22 & 178 \\
& & & Lime............. & 3 & 181 \\
& & & 5 & 186 & \\
\hline
\end{tabular}

V. A. Frost well No. 2.

\begin{tabular}{|c|c|c|c|c|c|c|}
\hline $\begin{array}{l}\text { White Plains Oil } \\
\text { \& Gas Co. }\end{array}$ & Rodemer pool..... & 655 & 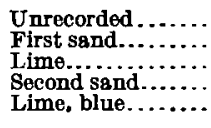 & $\begin{array}{r}178 \\
2 \\
6 \\
2 \\
35\end{array}$ & $\begin{array}{l}178 \\
180 \\
186 \\
188 \\
223\end{array}$ & \\
\hline
\end{tabular}

v. A. Frost well No. 3.

\begin{tabular}{|c|c|c|c|c|c|c|}
\hline $\begin{array}{l}\text { White Plains Oil } \\
\text { \& Gas Co. }\end{array}$ & Rodemer pool. & 695 & $\begin{array}{l}\text { Unrecorded. ...... } \\
\text { First sand ......... } \\
\text { Lime............. } \\
\text { Big pay.......... }\end{array}$ & $\begin{array}{r}219 \\
4 \\
17 \\
6\end{array}$ & $\begin{array}{l}219 \\
223 \\
240 \\
246\end{array}$ & $\begin{array}{l}\text { Was later deepened } \\
26 \text { feet and gave } \\
\text { a show of oil at } \\
260 \text { feet. }\end{array}$ \\
\hline
\end{tabular}


Records of wells in Allen County, Ky.-Continued.

V. A. Frost well No. 4.

\begin{tabular}{|c|c|c|c|c|c|c|}
\hline \multirow{2}{*}{$\begin{array}{l}\text { Owner or source } \\
\text { of information. }\end{array}$} & \multirow{2}{*}{ Location. } & \multirow{2}{*}{$\begin{array}{l}\text { Alti- } \\
\text { tude. }\end{array}$} & \multicolumn{3}{|c|}{ Driller's log. } & \multirow{2}{*}{ Remarks. } \\
\hline & & & Formation. & $\begin{array}{l}\text { Thick- } \\
\text { ness. }\end{array}$ & Depth. & \\
\hline $\begin{array}{l}\text { White Plains Oil } \\
\text { \& Oas Co. }\end{array}$ & Rodemer pool. & $\begin{array}{l}\text { Feet. } \\
700\end{array}$ & 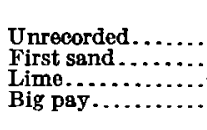 & $\begin{array}{r}\text { Feet. } \\
181 \\
13 \\
7 \\
-\quad 4\end{array}$ & $\begin{array}{r}\text { Feet. } \\
181 \\
194 \\
201 \\
205\end{array}$ & $\begin{array}{l}\text { Was later deepened } \\
\mathbf{2 3} \text { feet and had } \\
\text { a good flow of oil } \\
\text { at } 225 \text { feet. }\end{array}$ \\
\hline
\end{tabular}

V. A. Frost well No. 5.

\begin{tabular}{|c|c|c|c|c|c|}
\hline $\begin{array}{l}\text { White Plains Oil } \\
\text { \& Gas Co. }\end{array}$ & Rodemer pool. & 659 & 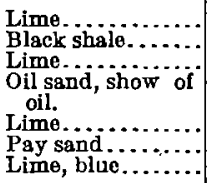 & $\begin{array}{r}123 \\
\mathbf{4 3} \\
16 \\
6 \\
3 \\
3 \\
3 \\
21\end{array}$ & $\begin{array}{l}123 \\
166 \\
182 \\
188 \\
191 \\
194 \\
1945\end{array}$ \\
\hline
\end{tabular}

V. A. Frost well No. 6.

\begin{tabular}{|c|c|c|c|c|}
\hline $\begin{array}{l}\text { White Plains Oil } \\
\text { \& Gas Co. }\end{array}$ & Rodemer pool.. & 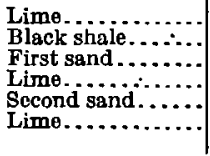 & $\begin{array}{r}180 \\
43 \\
18 \\
4 \\
15 \\
2\end{array}$ & $\begin{array}{l}180 \\
223 \\
241 \\
245 \\
260 \\
262\end{array}$ \\
\hline
\end{tabular}

V. A. Frost well No. 7 .

\begin{tabular}{|c|c|c|c|c|c|c|}
\hline $\begin{array}{l}\text { White Plains Oil } \\
\text { \& Gas Co. }\end{array}$ & $\begin{array}{l}\text { Northwest margin } \\
\text { of Rodemer pool. }\end{array}$ & ......... & 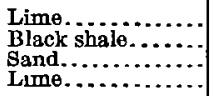 & $\begin{array}{r}118 \\
38 \\
32 \\
5\end{array}$ & $\begin{array}{l}118 \\
156 \\
188 \\
193\end{array}$ & $\begin{array}{l}\text { Shot from } 156 \text { to } \\
189 \text { feet. Hole } \\
\text { dry. }\end{array}$ \\
\hline
\end{tabular}

V. A. Frost well No. 8.

\begin{tabular}{|c|c|c|c|c|c|}
\hline $\begin{array}{l}\text { White Plains Oil } \\
\& \text { Gas Co. }\end{array}$ & $\begin{array}{l}\text { Northwest margin } \\
\text { of Rodemer pool. }\end{array}$ & $\begin{array}{l}\text { Lime } \\
\text { Black shäl........... }\end{array}$ & $\begin{array}{r}155 \\
433\end{array}$ & $\begin{array}{l}155 \\
198\end{array}$ & $\begin{array}{l}\text { No record below } \\
\text { black shale. } \\
\text { Hole dry. }\end{array}$ \\
\hline
\end{tabular}

V. A. Frost well No. 9.

\begin{tabular}{|c|c|c|c|c|c|c|}
\hline $\begin{array}{l}\text { White Plains Oil } \\
\text { \& Gas Co. }\end{array}$ & Rodemer pool..... & 654 & 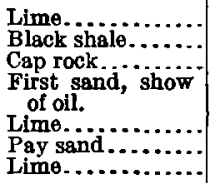 & $\begin{array}{r}126 \\
45 \\
12 \\
4 \\
9 \\
6 \\
7\end{array}$ & $\begin{array}{l}126 \\
171 \\
183 \\
187 \\
196 \\
202 \\
209\end{array}$ & $\begin{array}{l}\text { Was later drilled } 23 \\
\text { feet deeper to } 232 \\
\text { feet with no re- } \\
\text { sult. }\end{array}$ \\
\hline
\end{tabular}

V. A. Frost well No. 10.

\begin{tabular}{|c|c|c|c|}
\hline $\begin{array}{l}\text { White Plains Oil } \\
\text { \& Gas Co. }\end{array}$ & Rodemer pool. & 659 & \\
\hline
\end{tabular}


Records of wells in Allen County, Ky.-Continued.

V. A. Frost well No. 11.

\begin{tabular}{|c|c|c|c|c|c|c|}
\hline \multirow{2}{*}{$\begin{array}{l}\text { Owner or source } \\
\text { of information. }\end{array}$} & \multirow{2}{*}{ Location. } & \multirow{2}{*}{$\begin{array}{l}\text { Alti- } \\
\text { tude. }\end{array}$} & \multicolumn{3}{|c|}{ Driller's log. } & \multirow{2}{*}{ Remarks. } \\
\hline & & & Formation. & $\begin{array}{l}\text { Thick- } \\
\text { ness. }\end{array}$ & Depth. & \\
\hline $\begin{array}{l}\text { White Plains Oil } \\
\text { \& Gas Co. }\end{array}$ & Rodemer pool. & $\begin{array}{r}\text { Feet. } \\
\mathbf{6 6 3}\end{array}$ & Original depth & Feet. & $\begin{array}{r}\text { Feet. } \\
\mathbf{2 4 0}\end{array}$ & $\begin{array}{l}\text { Was later drilled to } \\
296 \text { feet without } \\
\text { flnding eil ther } \\
\text { water or oil. }\end{array}$ \\
\hline
\end{tabular}

V. A. Frost well No. 12.

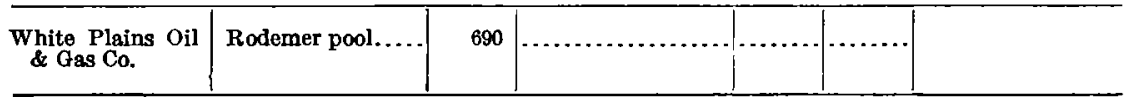

V. A. Frost well No. 15.

\begin{tabular}{|c|c|c|c|c|c|}
\hline $\begin{array}{l}\text { White Plains Oil } \\
\text { \& Gas Co. }\end{array}$ & Rodemer pool. & 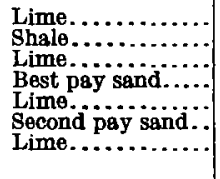 & $\begin{array}{r}200 \\
51 \\
24 \\
4 \\
3 \\
\cdot 13 \\
3\end{array}$ & $\begin{array}{l}200 \\
251 \\
275 \\
279 \\
282 \\
295 \\
298\end{array}$ & $\begin{array}{l}\text { Completed Apr. } \\
1916 \text {, Reported } \\
\text { initial produc- } \\
\text { tion, } 100 \text { barrels. } \\
\text { Drilled to } 332 \text { feet } \\
\text { January } 1917 \\
\text { "showed more } \\
\text { oil all along." }\end{array}$ \\
\hline
\end{tabular}

v. A. Frost well No. 16.

\begin{tabular}{|c|c|c|c|c|c|c|}
\hline $\begin{array}{l}\text { White Plains Oil } \\
\text { \& Gas Co. }\end{array}$ & Rodemer pool..... & ….... & 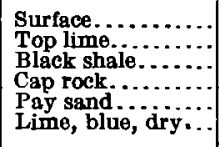 & $\begin{array}{r}8 \\
102 \\
50 \\
7 \\
5 \\
39\end{array}$ & $\begin{array}{r}8 \\
110 \\
160 \\
167 \\
172 \\
211\end{array}$ & $\begin{array}{l}\text { Drilled in April } \\
\text { 1916. Reported } \\
\text { initial produc- } \\
\text { tion, } 100 \text { barrels. }\end{array}$ \\
\hline
\end{tabular}

v. A. Frost well No. 17.

\begin{tabular}{|c|c|c|c|c|c|c|}
\hline $\begin{array}{l}\text { White Plains Oil } \\
\& \text { Gas Co. }\end{array}$ & Rodemer pool.... & …..... & $\begin{array}{l}\text { Surface........... } \\
\text { Top lime.......... } \\
\text { Black shale....... } \\
\text { Lime sand....... }\end{array}$ & $\begin{array}{r}12 \\
111 \\
46 \\
62\end{array}$ & $\begin{array}{r}12 \\
123 \\
169 \\
231\end{array}$ & $\begin{array}{l}\text { Very light show of } \\
\text { oil at } 173 \text { feet. } \\
\text { Two bailers of } \\
\text { water at } 200 \text { feet, } \\
\text { Casing pulled } \\
\text { and well plugged. }\end{array}$ \\
\hline
\end{tabular}

V. A. Frost well No. 18.

\begin{tabular}{|c|c|c|c|c|c|c|}
\hline $\begin{array}{l}\text { White Plains Oil } \\
\mathcal{E}_{\text {d Gas Co. }}\end{array}$ & Rodemer pool. & 766 & 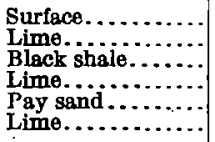 & $\begin{array}{r}27 \\
195 \\
51 \\
40 \\
5 \\
8\end{array}$ & \begin{tabular}{r|r|}
27 \\
222 \\
273 \\
313 \\
313 \\
326
\end{tabular} & $\begin{array}{l}\text { Hole flled up } 35 \\
\text { feet overnight } \\
\text { from the pay } \\
\text { sand. Reported } \\
\text { initial produc. } \\
\text { tion, } 10 \text { barrels. }\end{array}$ \\
\hline
\end{tabular}

V. A. Frost well No. 19.

\begin{tabular}{|c|c|c|c|c|c|c|}
\hline $\begin{array}{l}\text { White Plains Oil } \\
\text { \& Ges Co. }\end{array}$ & Rodemer pool.. & 713 & 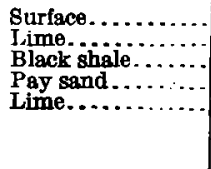 & $\begin{array}{r}18 \\
165 \\
47 \\
5 \\
42\end{array}$ & $\begin{array}{r}18 \\
183 \\
230 \\
235 \\
277\end{array}$ & $\begin{array}{l}\text { Crevice at } 249 \text { feet } \\
\text { Hole did not fill } \\
\text { up over } 35 \text { feet } \\
\text { but pumped } 18 \\
\text { hours. Estimat. } \\
\text { edinitial produc } \\
\text { tion, } 20 \text { barrels. }\end{array}$ \\
\hline
\end{tabular}


Records of wells in Allen County, Ky.-Continued.

V. A. Frost well No. 20.

\begin{tabular}{|c|c|c|c|c|c|c|}
\hline \multirow{2}{*}{$\begin{array}{l}\text { Owner or source } \\
\text { of information. }\end{array}$} & \multirow{2}{*}{ Location. } & \multirow{2}{*}{$\begin{array}{l}\text { Alti- } \\
\text { tude. }\end{array}$} & \multicolumn{3}{|c|}{ Driller's log. } & \multirow{2}{*}{ Remarks. } \\
\hline & & & Formation. & $\begin{array}{l}\text { Thick- } \\
\text { ness. }\end{array}$ & Depth. & \\
\hline $\begin{array}{l}\text { White Plains Oil } \\
\text { \& Gas Co. }\end{array}$ & Rodemer pool..... & $\begin{array}{l}\text { Feet. } \\
715\end{array}$ & 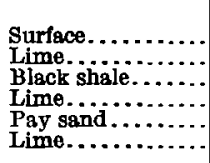 & $\begin{array}{r}\text { Feet. } \\
18 \\
169 \\
43 \\
30 \\
5 \\
22\end{array}$ & $\begin{array}{r}\text { Feet. } \\
18 \\
187 \\
230 \\
260 \\
265 \\
287\end{array}$ & $\begin{array}{l}\text { Showing rery light. } \\
\text { Estimated pro- } \\
\text { duction, } 2 \text { bar- } \\
\text { rels. }\end{array}$ \\
\hline
\end{tabular}

V. A. Frost well No. 21.

\begin{tabular}{|c|c|c|c|c|c|c|}
\hline $\begin{array}{l}\text { White Plains Oil } \\
\text { \& Gas Co. }\end{array}$ & Rodemer pool..... & 720 & $\begin{array}{l}\text { Surface } \ldots . . . \\
\text { Lime. } \\
\text { Black shaic ........ } \\
\text { Lime and sand.... }\end{array}$ & $\begin{array}{r}18 \\
170 \\
42 \\
51\end{array}$ & $\begin{array}{r}18 \\
188 \\
230 \\
281\end{array}$ & $\begin{array}{l}\text { Pay at } 246 \text { feet } \\
\text { showed about } 10 \\
\text { barrels. }\end{array}$ \\
\hline
\end{tabular}

V. A. Frost well No. 22.

\begin{tabular}{|c|c|c|c|c|c|c|}
\hline $\begin{array}{l}\text { White Plains Oil } \\
\text { \& Gas Co. }\end{array}$ & Rodemer pool.... & 750 & 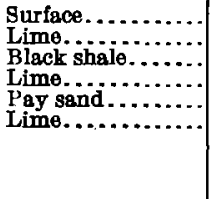 & $\begin{array}{r}12 \\
206 \\
36 \\
10 \\
5 \\
58\end{array}$ & $\begin{array}{r}12 \\
218 \\
254 \\
264 \\
269 \\
327\end{array}$ & $\begin{array}{l}\text { Crevice at } 270 \text { feet. } \\
\text { Pumped over } 400 \\
\text { barrels the first } \\
\text { day but dropped } \\
\text { to } 2 \text { barrels in a } \\
\text { weel. Drilled to } \\
350 \text { feet July, } \\
1916 \text {, with no } \\
\text { beneficial results. }\end{array}$ \\
\hline
\end{tabular}

V. A. Frost well No. 23.

\begin{tabular}{|c|c|c|c|c|c|c|}
\hline $\begin{array}{l}\text { White Plains Oil } \\
\text { \& Gas Co. }\end{array}$ & Rodemer pool.... & 750 & 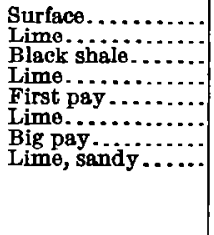 & $\begin{array}{r}40 \\
177 \\
44 \\
30 \\
4 \\
6 \\
.4 \\
5\end{array}$ & $\begin{array}{l}40 \\
217 \\
261 \\
291 \\
295 \\
301 \\
305 \\
310\end{array}$ & $\begin{array}{l}\text { Water at } 310 \text { feet; } \\
\text { wel plugged } \\
\text { with w ooden } \\
\text { plug up to } 305 \\
\text { feet. Hole filled } \\
\text { up } 50 \text { feet in sec- } \\
\text { ond pay before } \\
\text { Water was struck. } \\
\text { Reported initial } \\
\text { production, } 10 \\
\text { barrels. }\end{array}$ \\
\hline
\end{tabular}

V. A. Frost well No. 24.

\begin{tabular}{|c|c|c|c|c|c|c|}
\hline $\begin{array}{l}\text { White Plains Oil } \\
\text { \& Cas Co. }\end{array}$ & Rodemer pool..... & $\ldots \ldots$ & 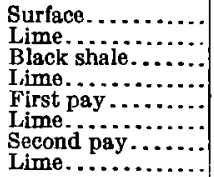 & $\begin{array}{r}9 \\
165 \\
51 \\
14 \\
4 \\
5 \\
5 \\
22\end{array}$ & $\begin{array}{r}9 \\
174 \\
225 \\
239 \\
243 \\
248 \\
253 \\
275\end{array}$ & $\begin{array}{l}\text { Small amount of } \\
\text { water at } 274 \text { feet. } \\
\text { W oll show ed } \\
\text { about } 5 \text { barrels } \\
\text { of oil. }\end{array}$ \\
\hline
\end{tabular}

V. A. Frost well No. 25.

\begin{tabular}{|c|c|c|c|c|c|}
\hline $\begin{array}{l}\text { White Plains Oil } \\
\text { \& Gas Co. }\end{array}$ & Rodemer pool. & $\begin{array}{l}\text { Burface } . . . \\
\text { Lime. } \\
\text { Black shale } . \\
\text { Lime............ } \\
\text { Pay sand...... }\end{array}$ & $\begin{array}{r}40 \\
194 \\
44 \\
32 \\
10\end{array}$ & $\begin{array}{r}40 \\
234 \\
278 \\
310 \\
320\end{array}$ & $\begin{array}{l}\text { Reported initia] } \\
\text { production, } 75 \\
\text { barrels. }\end{array}$ \\
\hline
\end{tabular}


Records of wells in Allen County, Ky.-Continued.

v. A. Frost well No. 26.

\begin{tabular}{|c|c|c|c|c|c|c|}
\hline \multirow{2}{*}{$\begin{array}{l}\text { Owner or source } \\
\text { of information. }\end{array}$} & \multirow{2}{*}{ Location. } & \multirow{2}{*}{$\begin{array}{l}\text { Alti- } \\
\text { tude. }\end{array}$} & \multicolumn{3}{|c|}{ Driller's log. } & \multirow{2}{*}{ Remarks. } \\
\hline & & & Formation. & $\begin{array}{l}\text { Thick- } \\
\text { ness. }\end{array}$ & Depth. & \\
\hline $\begin{array}{l}\text { White Plains Oil } \\
\text { \& Gas Co. }\end{array}$ & $\begin{array}{l}\text { North margin of } \\
\text { Rodemer field. }\end{array}$ & $\begin{array}{c}\text { Feet. } \\
\cdots\end{array}$ & 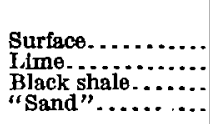 & $\begin{array}{r}\text { Feet. } \\
18 \\
224 \\
49 \\
\end{array}$ & $\begin{array}{r}\text { Feet. } \\
18 \\
212 \\
291 \\
2 . .\end{array}$ & $\begin{array}{l}\text { Water at } 370 \text { feet. } \\
\text { No oil. Casing } \\
\text { pulled and hole } \\
\text { plugged. }\end{array}$ \\
\hline
\end{tabular}

Grabb well No. 1.

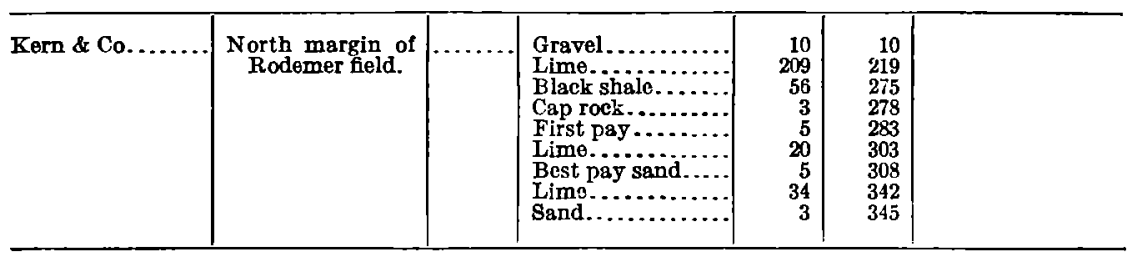

Guy well No. 1.

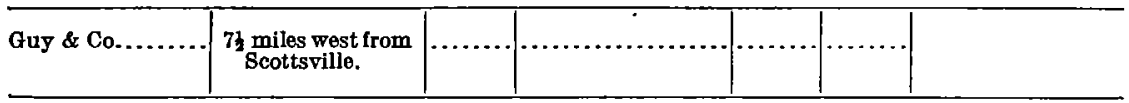

Guy well No. 2.

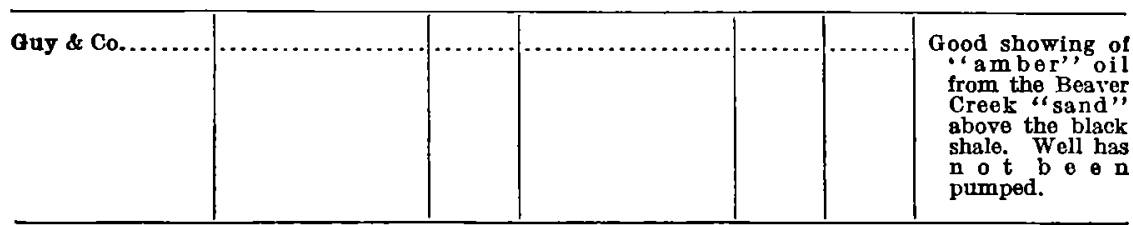

Hinton well No. 1.

\begin{tabular}{|c|c|c|c|c|c|c|}
\hline $\begin{array}{l}\text { White Plains Oil } \\
\text { \& Gas Co. }\end{array}$ & $\begin{array}{l}\text { milenortheast of } \\
\text { Rodemer pool. }\end{array}$ & 708 & $\begin{array}{l}\text { Unrecorded . . . . . . } \\
\text { Sand.............. }\end{array}$ & $\begin{array}{l}265 \\
233\end{array}$ & $\begin{array}{l}265 \\
288\end{array}$ & $\begin{array}{l}\text { Shot. A steady } \\
\text { smallproducer. }\end{array}$ \\
\hline
\end{tabular}

Hinton well No. 2.

\begin{tabular}{|c|c|c|c|c|c|c|}
\hline $\begin{array}{l}\text { White Plains Oll } \\
\text { \& Gas Co. }\end{array}$ & $\begin{array}{l}1 \text { mile northeast of } \\
\text { Rodemer pool. }\end{array}$ & $\ldots \ldots$ & $\begin{array}{l}\text { Unrecorded........ } \\
\text { Sand................ }\end{array}$ & $\begin{array}{r}265 \\
25\end{array}$ & $\begin{array}{l}265 \\
290\end{array}$ & $\begin{array}{l}\text { Shot. Not enough } \\
\text { oil to pay for } \\
\text { pumping. }\end{array}$ \\
\hline
\end{tabular}

Hinton well No. 6.

\begin{tabular}{|c|c|c|c|c|c|c|}
\hline $\begin{array}{l}\text { White PIains Ofl } \\
\text { \& Gas Co. }\end{array}$ & $\begin{array}{l}\frac{1}{2} \text { milenortheest of } \\
\text { Rodemer pool. }\end{array}$ & 716 & $\begin{array}{l}\text { Surface........... } \\
\text { Lime ............ } \\
\text { Black shale . . . }\end{array}$ & $\begin{array}{r}22 \\
188 \\
40 \\
104\end{array}$ & $\begin{array}{r}22 \\
210 \\
250 \\
354\end{array}$ & $\begin{array}{l}\text { Pay at } 275 \text { feet very } \\
\text { light. Bhowed } \\
\text { some water with } \\
\text { oll. }\end{array}$ \\
\hline
\end{tabular}

Hinton well No. 7.

\begin{tabular}{|c|c|c|c|c|c|}
\hline $\begin{array}{l}\text { White Plains Oil } \\
\text { \& Gas Co. }\end{array}$ & $\begin{array}{l}1 \text { milenortheast of } \\
\text { Rodemer pool. }\end{array}$ & 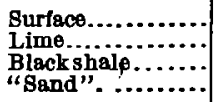 & $\begin{array}{r}10 \\
200 \\
42 \\
96\end{array}$ & $\begin{array}{r}10 \\
210 \\
252 \\
348\end{array}$ & $\begin{array}{l}\text { Gas at } 275 \text { feet and } \\
\text { faint show of oil } \\
\text { at } 295 \text { feet. Hole } \\
\text { plugged. }\end{array}$ \\
\hline
\end{tabular}


Records of wells in Allen County, Ky.-Continued.

Hinton well No. 8.

\begin{tabular}{|c|c|c|c|c|c|c|}
\hline \multirow{2}{*}{$\begin{array}{l}\text { Owner or source } \\
\text { of information. }\end{array}$} & \multirow{2}{*}{ Location. } & \multirow{2}{*}{$\begin{array}{l}\text { Alti- } \\
\text { tude. }\end{array}$} & \multicolumn{3}{|c|}{ Driller's log. } & \multirow{2}{*}{ Remarks. } \\
\hline & & & Formation. & $\begin{array}{c}\text { Thick- } \\
\text { ness. }\end{array}$ & Depth. & \\
\hline $\begin{array}{l}\text { White Plains Oil } \\
\text { \& Gas Co. }\end{array}$ & $\begin{array}{l}\text { mile northeast of } \\
\text { Rodemer pool. }\end{array}$ & $\begin{array}{r}\text { Feet. } \\
751\end{array}$ & 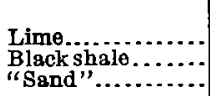 & $\begin{array}{r}\text { Feet. } \\
250 \\
45 \\
100\end{array}$ & $\begin{array}{r}\text { Feet. } \\
250 \\
295 \\
395\end{array}$ & Dry hole. \\
\hline
\end{tabular}

Hornbuckle well No, 2.

\begin{tabular}{|c|c|c|c|c|c|c|}
\hline $\begin{array}{l}\text { White Plains Oil } \\
\text { \& Gas Co. }\end{array}$ & $\begin{array}{l}\text { mile north of } \\
\text { Rodemer pool. }\end{array}$ & & $\begin{array}{l}\text { Lime and shale.... } \\
\text { Black shale . . . . . } \\
\text { "Sand" .......... }\end{array}$ & $\begin{array}{r}178 \\
54 \\
95\end{array}$ & $\begin{array}{l}178 \\
232 \\
327\end{array}$ & $\begin{array}{l}\text { Faint show of oil at } \\
271 \text { feet. Holo } \\
\text { plugged. }\end{array}$ \\
\hline
\end{tabular}

E. Huntsman well No. 1.

\begin{tabular}{|c|c|c|c|c|c|c|}
\hline $\begin{array}{l}\text { White Plains Oil } \\
\& \text { Gas Co }\end{array}$ & n. & $\ldots \ldots$ & $\begin{array}{l}\text { Surface } \\
\text { Lime } \\
\text { Black shale } \ldots . . . . \\
\text { Lime and sand.... }\end{array}$ & $\begin{array}{r}12 \\
100 \\
39 \\
87\end{array}$ & $\begin{array}{r}12 \\
112 \\
151 \\
238\end{array}$ & $\begin{array}{l}\text { Faint show of ofl at } \\
211 \text { feet. Water } \\
\text { at } 238 \text { feet. }\end{array}$ \\
\hline
\end{tabular}

Jones well No. 1.

\begin{tabular}{|c|c|c|c|c|c|c|}
\hline $\begin{array}{l}\text { White Plains Oil } \\
\text { \& Ges Co. }\end{array}$ & $\begin{array}{l}\text { North Petroleum } \\
\text { pool or north } \\
\text { margin of pro- } \\
\text { duction. }\end{array}$ & 718 & 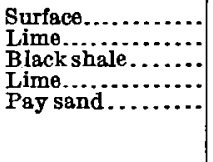 & $\begin{array}{r}30 \\
110 \\
41 \\
29 \\
7\end{array}$ & $\begin{array}{r}30 \\
140 \\
181 \\
210 \\
217\end{array}$ & $\begin{array}{l}\text { Produced } 100 \text { bar- } \\
\text { rels first } 24 \text { hours. } \\
\text { Drilled in Dec. } \\
\text { 1916, to } 262 \text { feet } \\
\text { and again deep- } \\
\text { ened in May, } \\
\text { 1917. }\end{array}$ \\
\hline
\end{tabular}

Jones well No. 2.

\begin{tabular}{|c|c|c|c|c|c|c|}
\hline $\begin{array}{l}\text { White PIains Oil } \\
\text { \& Gas Co. }\end{array}$ & $\begin{array}{l}500 \text { feet north of } \\
\text { No. } 1 \text {. }\end{array}$ & 727 & $\begin{array}{l}\text { Surface.......... } \\
\text { Lime............. } \\
\text { Black shale....... } \\
\text { "Sand" }\end{array}$ & $\begin{array}{r}30 \\
131 \\
42 \\
85\end{array}$ & $\begin{array}{r}30 \\
161 \\
203 \\
288\end{array}$ & $\begin{array}{l}\text { Water at } 288 \text { feet; } \\
\text { hole plugged. }\end{array}$ \\
\hline
\end{tabular}

Martha Keen well No. 1.

\begin{tabular}{|c|c|c|c|c|c|c|}
\hline Good Luck OilCo. & Rodemer pool...... & 654 & 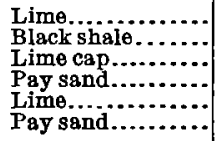 & $\begin{array}{r}123 \\
44 \\
2 \\
23 \\
9 \\
4\end{array}$ & $\begin{array}{l}123 \\
167 \\
169 \\
192 \\
201 \\
205\end{array}$ & $\begin{array}{l}\text { Pumped } 60 \text { barrels } \\
\text { for } 4 \text { days and } \\
\text { then settled. to } \\
10 \text { barrels. }\end{array}$ \\
\hline
\end{tabular}

Marths Keen well No. 2.

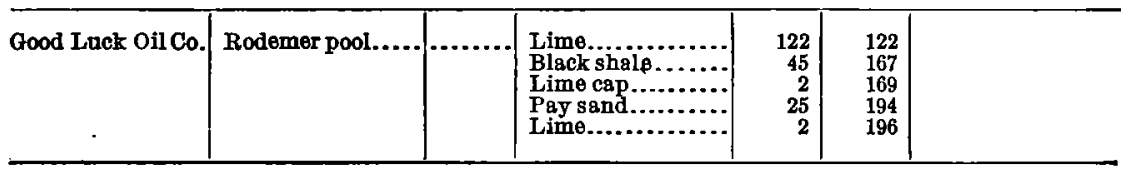

Martha Keen well No. 3.

\begin{tabular}{|c|c|c|c|c|c|}
\hline Good Luck Oll Co. & Rodemer pool..... & 658 & 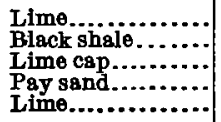 & $\begin{array}{r}134 \\
45 \\
2 \\
19 \\
2\end{array}$ & $\begin{array}{l}134 \\
179 \\
181 \\
200 \\
202\end{array}$ \\
\hline
\end{tabular}


Records of wells in Allen County, Ky.-Continued.

Martha Keen well No. 4.

\begin{tabular}{|c|c|c|c|c|c|c|}
\hline \multirow{2}{*}{$\begin{array}{l}\text { Owner or source } \\
\text { of information. }\end{array}$} & \multirow{2}{*}{ Location. } & \multirow{2}{*}{$\begin{array}{l}\text { Alti- } \\
\text { tude. }\end{array}$} & \multicolumn{3}{|c|}{ Driller's log. } & \multirow{2}{*}{ Remarks. } \\
\hline & & & Formation. & $\begin{array}{c}\text { Thick- } \\
\text { ness. }\end{array}$ & Depth. & \\
\hline Good Luck Oil Co. & Rodemer pool..... & Feet. & 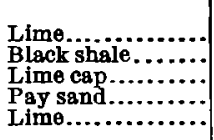 & $\begin{array}{r}\text { Feet. } \\
122 \\
44 \\
6 \\
24 \\
12\end{array}$ & $\begin{array}{r}\text { Feet. } \\
122 \\
166 \\
172 \\
196 \\
208\end{array}$ & \\
\hline
\end{tabular}

Martha Keen well No. 5.

\begin{tabular}{|c|c|c|c|c|c|c|}
\hline Good Luck Oil Co. & Rodemer pool...... & 717 & 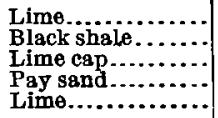 & $\begin{array}{r}183 \\
47 \\
3 \\
15 \\
23\end{array}$ & $\begin{array}{l}183 \\
230 \\
233 \\
248 \\
271\end{array}$ & $\begin{array}{l}\text { Drilled to } 285 \text { feet } \\
\text { in Apr., } 1917 . \\
\text { Blue-gray clay } \\
\text { shale at } 275 \text { to } \\
285 \text { feet. }\end{array}$ \\
\hline
\end{tabular}

Martha Keen well No. 6.

\begin{tabular}{|c|c|c|c|c|c|c|}
\hline Good Luck Oll Co. & Rodemer pool..... & 698 & $\begin{array}{l}\text { Lime } \\
\text { Black shale........ } \\
\text { Lime cap.......... } \\
\text { Pay sand ........... }\end{array}$ & $\begin{array}{r}165 \\
47 \\
3 \\
15\end{array}$ & $\begin{array}{l}165 \\
212 \\
215 \\
230\end{array}$ & $\begin{array}{l}\text { Deepened to } 292 \\
\text { feet and got salt } \\
\text { water but not } \\
\text { enough oil to pay. }\end{array}$ \\
\hline
\end{tabular}

Martha Keen well No. 7 .

\begin{tabular}{|c|c|c|c|c|c|}
\hline Good Luck Oil Co. & Rodemer pool..... & 654 & 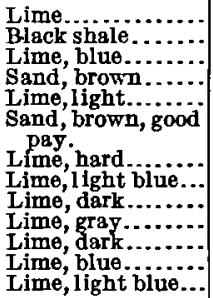 & $\begin{array}{r}120 \\
43 \\
11 \\
3 \\
6 \\
9 \\
2 \\
9 \\
2 \\
1 \\
6 \\
10 \frac{1}{2} \\
2 \frac{1}{2}\end{array}$ & $\begin{array}{l}-120 \\
163 \\
174 \\
177 \\
183 \\
192 \\
194 \\
203 \\
205 \\
206 \\
212 \\
2221 \\
225\end{array}$ \\
\hline
\end{tabular}

Martha Keen well No. 8.

\begin{tabular}{|c|c|c|c|c|c|c|}
\hline Good Luck Oil Co. & Rodemer pool..... & …..... & $\begin{array}{l}\text { Lime } \\
\text { Black shale........... } \\
\text { Sand............. } \\
\text { Sand, brown, good } \\
\text { pay, jight, pay.... } \\
\text { Sand, light, payn } \\
\text { Lime, light hrown. } \\
\text { Lime, light blue... }\end{array}$ & $\begin{array}{r}115 \\
43 \\
10 \\
5 \\
5 \\
5 \\
7 \\
9\end{array}$ & $\begin{array}{l}115 \\
158 \\
168 \\
173 \\
173 \\
185 \\
194\end{array}$ & $\begin{array}{l}\text { First pay at } 163 \\
\text { feet. Reported } \\
\text { initial produc- } \\
\text { tion, } 75 \text { barrels. }\end{array}$ \\
\hline
\end{tabular}

Marthe Keen well No. 9.

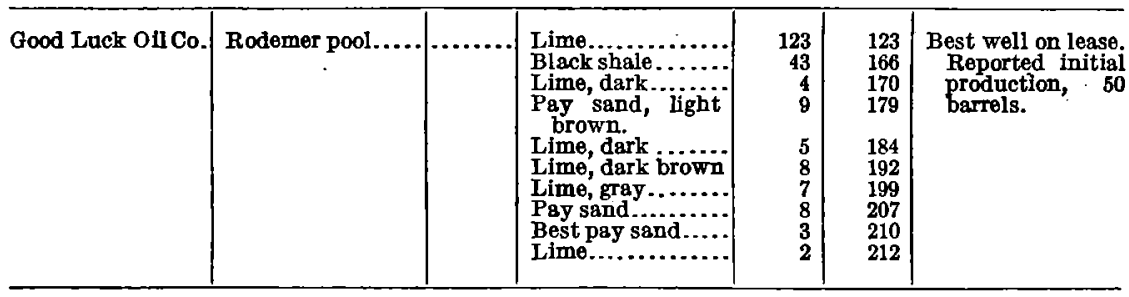


Records of wells in Allen County, Ky.-Continued.

Martha Keen well No. 10.

\begin{tabular}{|c|c|c|c|c|c|c|}
\hline \multirow{2}{*}{$\begin{array}{l}\text { Owner or solurce } \\
\text { of information. }\end{array}$} & \multirow{2}{*}{ Location. } & \multirow{2}{*}{$\begin{array}{l}\text { Alti- } \\
\text { tude. }\end{array}$} & \multicolumn{3}{|c|}{ Driller's log. } & \multirow{2}{*}{ Remarks. } \\
\hline & & & Formation. & $\begin{array}{l}\text { Thick- } \\
\text { ness. }\end{array}$ & Depth. & \\
\hline Good Luck Oll Co. & Rodemer pool..... & $\begin{array}{r}\text { Feet. } \\
672\end{array}$ & $\begin{array}{l}\text { Lime............ } \\
\text { Black shale ..... } \\
\text { Lime, gray ...... } \\
\text { Sand, light brown. } \\
\text { Lime, light blue... } \\
\text { Oil sand, best pay. } \\
\text { Lime, dark blue... } \\
\text { Salt water, light } \\
\text { show of oll. } \\
\text { "Band, dry"...... } \\
\text { Lime............... }\end{array}$ & $\begin{array}{c}\text { Feet. } \\
130 \\
43 \\
11 \\
10 \frac{1}{2} \\
15 \\
5 \\
9 \frac{1}{2} \\
10^{2} \\
5 \frac{1}{2} \\
18\end{array}$ & $\begin{array}{c}\text { Feet. } \\
130 \\
173 \\
184 \\
1941 \\
209 \frac{1}{2} \\
214 \frac{1}{2} \\
224 \\
234 \\
\\
2391 \\
257 \frac{1}{2}\end{array}$ & $\begin{array}{l}\text { Open crevice in } \\
\text { blue lime at } 2143 \\
\text { feet. Reported } \\
\text { initial produc- } \\
\text { tion, } 40 \text { barrels. }\end{array}$ \\
\hline
\end{tabular}

Martha Keen well No. 11.

\begin{tabular}{|c|c|c|c|c|c|c|}
\hline Good Luck Oll Co. & Rodemer pool..... & $\ldots \ldots$ & $\begin{array}{l}\text { Lime.............. } \\
\text { Black shale........ } \\
\text { Lime, light....... } \\
\text { Oil sand (show)... } \\
\text { Lime, blue ........ } \\
\text { Sand, dark brown, } \\
\text { little pay. } \\
\text { Lime, dark ......... } \\
\text { Lime, light. ....... } \\
\text { Lime, blue......... }\end{array}$ & $\begin{array}{r}140 \\
45 \\
5 \\
10 \\
5 \\
10 \\
5 \\
10 \\
7 \frac{1}{2}\end{array}$ & $\begin{array}{l}40 \\
185 \\
190 \\
200 \\
205 \\
215 \\
220 \\
230 \\
2371\end{array}$ & $\begin{array}{l}\text { Reported initial } \\
\text { production, } 10 \\
\text { barrels. }\end{array}$ \\
\hline
\end{tabular}

Martha Keen well No. 12.

\begin{tabular}{l|l|r|r|r|r|r|}
\hline Good Luck Oil Co. & Rodemer pool..... & 705 & No record ........................ & $\begin{array}{c}\text { Reported initial } \\
\text { production, } \\
\text { barrels. }\end{array}$ \\
\hline
\end{tabular}

Martha Keen well No. 13.

\begin{tabular}{|c|c|c|c|c|c|c|}
\hline Good Luck Oil Co. & Rodemer pool..... & 728 & 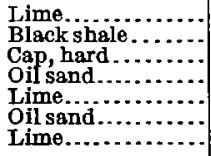 & $\begin{array}{r}185 \\
49 \\
5 \\
15 \\
10 \\
20 \\
22\end{array}$ & $\begin{array}{l}185 \\
234 \\
239 \\
254 \\
264 \\
284 \\
306\end{array}$ & $\begin{array}{l}\text { Water sand at } 306 \\
\text { feet. Reported } \\
\text { initial produc- } \\
\text { tion, } 10 \text { barrels. }\end{array}$ \\
\hline
\end{tabular}

Martha Keen well No. 14.

\begin{tabular}{|c|c|c|c|c|c|c|}
\hline Good Luck Oil Co. & Rodemer pool..... & 723 & $\begin{array}{l}\text { Lime } \\
\text { Black shale........ } \\
\text { Oil sand, pay ..... } \\
\text { Lime............ } \\
\text { Oil sand, show oil. } \\
\text { Lime................ }\end{array}$ & $\begin{array}{r}182 \\
48 \\
15 \\
33 \\
4 \\
48\end{array}$ & $\begin{array}{l}182 \\
230 \\
245 \\
278 \\
282 \\
330\end{array}$ & $\begin{array}{l}\text { Salt water at } 325 \\
\text { feet. Plugged up } \\
\text { to } 290 \text { feet. Re- } \\
\text { ported initial } \\
\text { production, } 20 \\
\text { barrels. }\end{array}$ \\
\hline
\end{tabular}

- Martha Keen well No. 15.

\begin{tabular}{|c|c|c|c|c|c|c|}
\hline Good Luck Oil Co. & Rodemer pool..... & 717 & 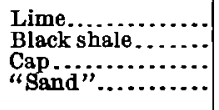 & $\begin{array}{r}190 \\
50 \\
3 \\
17\end{array}$ & $\begin{array}{l}190 \\
240 \\
243 \\
260\end{array}$ & $\begin{array}{l}\text { Reported initial } \\
\text { production, } \\
\text { barrels. }\end{array}$ \\
\hline
\end{tabular}


Records of wells in Allen County, Ky.-Continued.

J. W. Knight well No. 1.

\begin{tabular}{|c|c|c|c|c|c|c|}
\hline \multirow{2}{*}{$\begin{array}{l}\text { Owner or source } \\
\text { of information. }\end{array}$} & \multirow{2}{*}{ Location. } & \multirow{2}{*}{$\begin{array}{l}\text { Alti- } \\
\text { tude. }\end{array}$} & \multicolumn{3}{|c|}{ Driller's log. } & \multirow{2}{*}{ Remarks. } \\
\hline & & & Formation. & $\begin{array}{c}\text { Thick- } \\
\text { ness. }\end{array}$ & Depth. & \\
\hline $\begin{array}{l}\text { White Plains Oil } \\
\text { \& Gas Co. }\end{array}$ & $\begin{array}{l}\text { Approxima t e } 1 \text { y } \\
\text { midway between } \\
\text { North Petrol- } \\
\text { eum and Rode- } \\
\text { mer pools. }\end{array}$ & $\begin{array}{r}\text { Feet. } \\
742\end{array}$ & 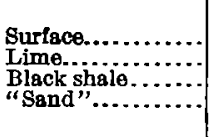 & $\begin{array}{r}\text { Feet. } \\
28 \\
179 \\
43 \\
185\end{array}$ & $\begin{array}{r}\text { Feet. } \\
28 \\
207 \\
250 \\
435\end{array}$ & Dry hole. \\
\hline
\end{tabular}

J. W. Knight well No. 2.

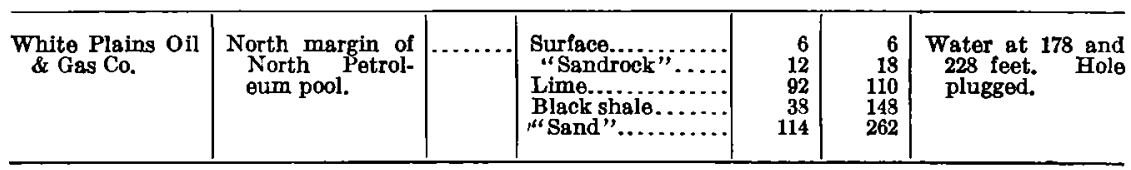

Lyle well No. 1.

\begin{tabular}{|c|c|c|c|c|c|}
\hline $\begin{array}{l}\text { White Plains Gas } \\
\text { \& Gas Co. }\end{array}$ & 1 mile east of $\mathrm{Po}$. & $\ldots$ & 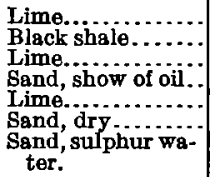 & $\begin{array}{r}140 \\
41 \\
33 \\
2 \\
8 \\
4 \\
1\end{array}$ & $\begin{array}{l}140 \\
181 \\
214 \\
216 \\
224 \\
228 \\
229\end{array}$ \\
\hline
\end{tabular}

Mantlo well No. 1.

\begin{tabular}{|c|c|c|c|c|c|c|}
\hline Kern \& Co ......... & Wildwood pool... & 782 & 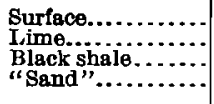 & $\begin{array}{r}20 \\
190 \\
45 \\
75\end{array}$ & $\begin{array}{r}20 \\
210 \\
255 \\
320\end{array}$ & $\begin{array}{l}\text { Pay between } 303 \\
\text { and } 319 \text { feet. }\end{array}$ \\
\hline
\end{tabular}

Mantlo well No. 2.

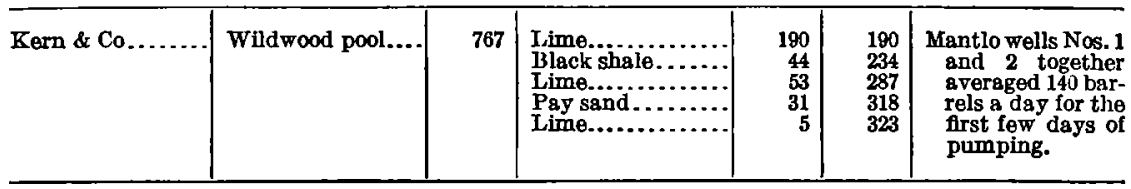

Mantlo well No. 3.

\begin{tabular}{|c|c|c|}
\hline Kern \& Co........ & Wildwood pool.... & $\begin{array}{l}\text { Lime............ } \\
\text { Black shale...... } \\
\text { Lime, soft, shelly, } \\
\text { dark gray. } \\
\text { Lime, light gray.... } \\
\text { Lime, light brown } \\
\text { Lime, green...... } \\
\text { Lime, brown, oil } \\
\text { odor, } \\
\text { Lime, shells, light } \\
\text { gray and brown. } \\
\text { Lime, sandy dark } \\
\text { brown. } \\
\text { oil pay......... } \\
\text { Sand, light brown, } \\
\text { no oil. } \\
\text { Lime, sandy, light } \\
\text { gray. }\end{array}$ \\
\hline
\end{tabular}

\begin{tabular}{r|r|}
176 & 176 \\
44 & 220 \\
8 & 228 \\
4 & 232 \\
6 & 238 \\
12 & 250 \\
8 & 258 \\
17 & 275 \\
10 & 285 \\
5 & 290 \\
11 & 301 \\
17 & 318 \\
\hline
\end{tabular}

Show of oil at 275 foet, best pay at 332 to 336 feet. Completed May 8, 1917. Bottom of "Corniferous" limestone probably at 275 feet. 
Records of wells in Allen County, Ky.-Continued.

Mantlo well No. 3-Continued.

\begin{tabular}{|c|c|c|c|c|c|c|}
\hline \multirow{2}{*}{$\begin{array}{l}\text { Owner or source } \\
\text { of information. }\end{array}$} & \multirow{2}{*}{ Location. } & \multirow{2}{*}{$\begin{array}{l}\text { A]ti- } \\
\text { tude. }\end{array}$} & \multicolumn{3}{|c|}{ Driller's log. } & \multirow{2}{*}{ Remarks. } \\
\hline & & & Formation. & $\begin{array}{l}\text { Thick- } \\
\text { ness. }\end{array}$ & Depth. & \\
\hline Kern \& Co......... & Wildwood pool.... & $\begin{array}{c}\text { Feet. } \\
\ldots \ldots\end{array}$ & $\begin{array}{l}\text { I.ime, shells, dark. } \\
\text { gray. } \\
\text { Slate, muddy ...... } \\
\text { Lime, black....... } \\
\text { Sand, dark gray .. } \\
\text { Sand, brown, oil } \\
\text { pay. } \\
\text { Sand, water......... }\end{array}$ & $\begin{array}{r}\text { Feet. } \\
4 \\
5 \\
2 \\
3 \\
4 \\
1\end{array}$ & $\begin{array}{r}\text { Feet. } \\
322 \\
\\
327 \\
329 \\
352 \\
336 \\
\\
337\end{array}$ & \\
\hline
\end{tabular}

Marsh well No. 1.

\begin{tabular}{|c|c|c|c|c|c|}
\hline $\begin{array}{l}\text { Petroleum Oil \& } \\
\text { Gas Co. }\end{array}$ & $\ldots$ & 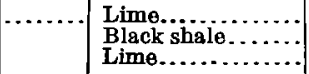 & $\begin{array}{l}36 \\
43 \\
36\end{array}$ & $\begin{array}{r}36 \\
79 \\
115\end{array}$ & Dry hole. \\
\hline \multicolumn{6}{|c|}{ Marsh well No. 2.} \\
\hline $\begin{array}{l}\text { Petroleum Oil \& } \\
\text { Gas Co. }\end{array}$ & $\ldots$ & 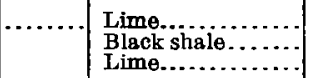 & $\begin{array}{r}159 \\
43 \\
59\end{array}$ & $\begin{array}{l}159 \\
202 \\
261\end{array}$ & Show of oil. \\
\hline
\end{tabular}

Marsh well No. 3.

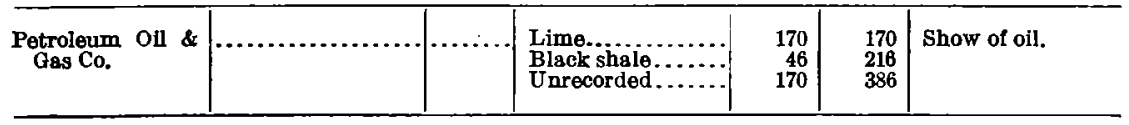

Meredith well No. 1.

\begin{tabular}{|c|c|c|c|c|c|c|}
\hline $\begin{array}{l}\text { White Plains Oil } \\
\text { \& Cas Co. }\end{array}$ & $\begin{array}{l}6 \text { miles northwest } \\
\text { of Seottsville. }\end{array}$ & $\ldots \ldots$ & 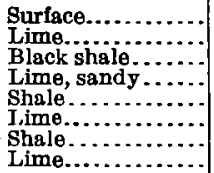 & $\begin{array}{r}6 \\
199 \\
54 \\
65 \\
9 \\
39 \\
23 \\
74\end{array}$ & $\begin{array}{r}6 \\
205 \\
259 \\
324 \\
333 \\
372 \\
395 \\
469\end{array}$ & $\begin{array}{l}\text { Very faint show of } \\
\text { oil at } 280 \text { feet. } \\
\text { Hole plugged. } \\
\text { Base of "Cornife- } \\
\text { rous" limestone } \\
\text { probably at } \mathbf{3 2 4} \\
\text { feet. }\end{array}$ \\
\hline
\end{tabular}

Burd Miller well No. 1.

\begin{tabular}{|c|c|c|c|c|c|c|}
\hline Heft \& Co.......... & $\begin{array}{l}\text { On Rough Creek, } \\
42 \text { miles south of } \\
\text { Scottsville. }\end{array}$ & $\ldots \ldots$ & $\begin{array}{l}\text { Lime and black } \\
\text { shale. } \\
\text { Cap rock } \ldots \ldots \ldots \ldots \\
\text { Oil sand } \ldots \ldots \ldots \ldots\end{array}$ & $\begin{array}{l}85 \\
27 \\
13\end{array}$ & $\begin{array}{r}85 \\
112 \\
125\end{array}$ & $\begin{array}{l}\text { Oil stands } 100 \text { leet } \\
\text { deep in the well. } \\
\text { Has not been } \\
\text { pumped (Apr. } \\
30,1917 \text { ). }\end{array}$ \\
\hline
\end{tabular}

Burd Miller well No. 2.

\begin{tabular}{|c|c|c|c|c|c|c|}
\hline Heft \& Co.......... & $\begin{array}{l}100 \text { yards east of } \\
\text { No. } 1 .\end{array}$ & $\because \because \cdots$ & $\begin{array}{l}\text { Lime and black } \\
\text { shale. } \\
\text { Total depth unre- } \\
\text { corded. }\end{array}$ & 82 & 82 & $\begin{array}{l}\text { Salt water and oil } \\
\text { in same sand at } \\
138 \text { feet. }\end{array}$ \\
\hline
\end{tabular}

Burd Miller well No. 3.

\begin{tabular}{|c|c|c|c|c|c|c|}
\hline Heft \& Co......... & $\begin{array}{l}50 \text { ygrds south of } \\
\text { No. } 1 .\end{array}$ & $\cdots \cdots$ & $\begin{array}{l}\text { Lime } \\
\text { Black shale } \\
\text { Total depth unre- } \\
\text { corded. }\end{array}$ & $\begin{array}{l}52 \\
40\end{array}$ & $\begin{array}{l}52 \\
92\end{array}$ & $\begin{array}{l}\text { Good showing of } \\
\text { oil. }\end{array}$ \\
\hline
\end{tabular}


Records of wells in Allen County, Ky.-Continued.

W. H. Miller well No. 1 (Burd Miller well No. 4).

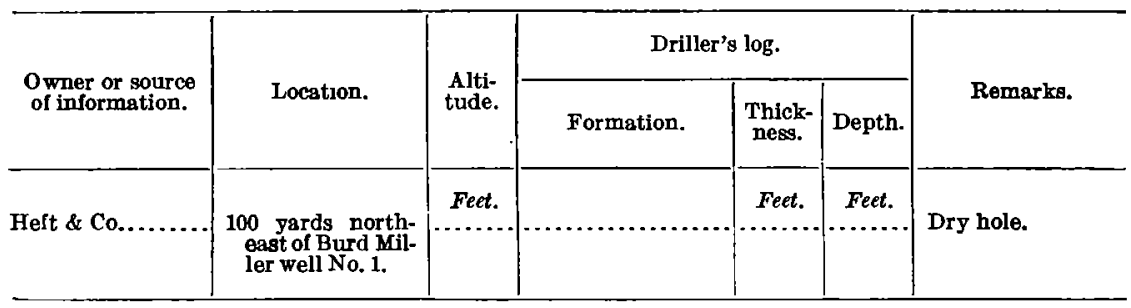

W. H. Miller well No. 2 (Burd Miller well No. 5).

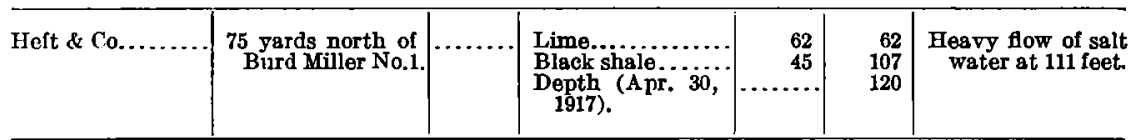

Paul Miller well No. 1.

\begin{tabular}{|c|c|c|c|c|c|c|}
\hline $\begin{array}{l}\text { White Plains Oil } \\
\text { \& Gas Co. }\end{array}$ & $\begin{array}{l}3 \text { miles northwest } \\
\text { of Scottsville. }\end{array}$ & $\ldots \ldots \ldots$ & $\begin{array}{l}\text { Surface............ } \\
\text { Lime. } \\
\text { Black shale........ } \\
\text { Lime and sand.... }\end{array}$ & $\begin{array}{r}10 \\
165 \\
43 \\
139\end{array}$ & $\begin{array}{r}10 \\
175 \\
218 \\
357\end{array}$ & Dry hole. \\
\hline
\end{tabular}

Moore well No. 1.

\begin{tabular}{|c|c|c|c|c|c|}
\hline $\begin{array}{l}\text { White Plains Oil } \\
\text { \& Gas Co. }\end{array}$ & $\begin{array}{l}\text { 9. miles northeast } \\
\text { of Scottsville. }\end{array}$ & $\begin{array}{l}\text { Unrecorded ....... } \\
\text { Black shale....... } \\
\text { Lime............ } \\
\text { Unrecorded ...... }\end{array}$ & $\begin{array}{l}20 \\
70 \\
70 \\
60\end{array}$ & $\begin{array}{r}20 \\
90 \\
160 \\
220\end{array}$ & $\begin{array}{l}\text { Good pay sand at } \\
160 \text { feet. }\end{array}$ \\
\hline
\end{tabular}

Myers well No. 1.

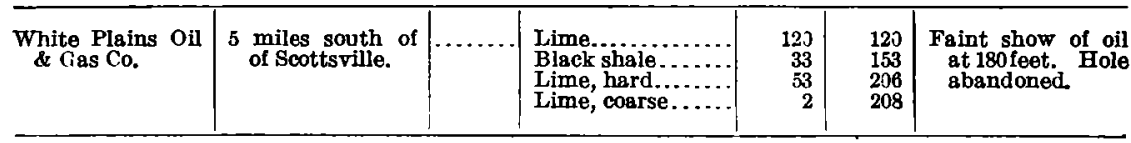

Denton Reeves well No. 1.

\begin{tabular}{|c|c|c|c|c|c|c|}
\hline $\begin{array}{l}\text { White Plains Oil } \\
\text { \& Gas Co. }\end{array}$ & $\begin{array}{l}\text { Wildwood pool, } \\
650 \text { feet north- } \\
\text { west of Fisher } \\
\text { well No. } 1 .\end{array}$ & 808 & $\begin{array}{l}\text { Surface........... } \\
\text { Lime............ } \\
\text { Shale, green...... } \\
\text { Black shale...... } \\
\text { "Shale"........ }\end{array}$ & $\begin{array}{r}35 \\
234 \\
7 \\
41 \\
85\end{array}$ & $\begin{array}{r}35 \\
239 \\
246 \\
237 \\
372\end{array}$ & $\begin{array}{l}\text { Oil pay between } \\
337 \text { and } 347 \text { feet. } \\
\text { Hole filled up } 50 \\
\text { foet with oil. } \\
\text { Has not been } \\
\text { pumped (May 10, } \\
\text { 1917). }\end{array}$ \\
\hline
\end{tabular}

Denton Reeves well No. 1.

\begin{tabular}{|c|c|c|c|c|c|c|}
\hline Southern Oil Co... & $\begin{array}{l}\text { West margin of } \\
\text { Wildwood pool. }\end{array}$ & 779 & 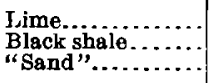 & $\begin{array}{r}251 \\
41 \\
24\end{array}$ & $\begin{array}{l}251 \\
292 \\
316\end{array}$ & $\begin{array}{l}\text { Initial production } \\
10 \text { barrels. }\end{array}$ \\
\hline
\end{tabular}

Denton Reeves well No. 2.

\begin{tabular}{|c|c|c|c|c|c|c|}
\hline Southern Oil Co. & $\begin{array}{l}\text { West margin of } \\
\text { Wildwood pool. }\end{array}$ & 802 & $\begin{array}{l}\text { Lime and shale. } \\
\text { Black shale....... } \\
\text { "Sand"......... }\end{array}$ & $\begin{array}{r}275 \\
45 \\
26\end{array}$ & $\begin{array}{l}275 \\
329 \\
346\end{array}$ & $\begin{array}{l}\text { First pay at } 328 \\
\text { feet. Initial pro- } \\
\text { duction } 10 \text { bar- } \\
\text { rels. }\end{array}$ \\
\hline
\end{tabular}


Records of wells in Allen County, Ky.-Continued.

Denton Reeves well No. 3.

\begin{tabular}{|c|c|c|c|c|c|c|}
\hline \multirow{2}{*}{$\begin{array}{l}\text { Owner or source } \\
\text { of information. }\end{array}$} & \multirow{2}{*}{ Location. } & \multirow{2}{*}{$\begin{array}{l}\text { Alti- } \\
\text { tude. }\end{array}$} & \multicolumn{3}{|c|}{ Driller's log. } & \multirow{2}{*}{ Remarks } \\
\hline & & & Formation. & $\begin{array}{l}\text { Thick- } \\
\text { ness. }\end{array}$ & Depth. & \\
\hline Southern Oil Co... & $\begin{array}{l}\text { West margin of } \\
\text { Wildwood pool. }\end{array}$ & $\begin{array}{l}\text { Feet. } \\
808\end{array}$ & No record. & Fect. & Fect. & \\
\hline
\end{tabular}

Reynolds well No. 1.

\begin{tabular}{|c|c|c|c|c|c|c|}
\hline $\begin{array}{l}\text { White Plains Oil } \\
\text { \& Gas Co. }\end{array}$ & $\begin{array}{l}5 \text { miles northwest } \\
\text { of Scottsville on } \\
\text { East Bay Fork. }\end{array}$ & $\ldots \ldots \ldots$ & $\begin{array}{l}\text { Surface............ } \\
\text { Lime.............. } \\
\text { Black shale...... } \\
\text { Lime and sand ... }\end{array}$ & $\begin{array}{r}11 \\
152 \\
46 \\
120\end{array}$ & $\begin{array}{r}11 \\
163 \\
209 \\
329\end{array}$ & $\begin{array}{l}\text { Completed Jan. 2, } \\
\text { I917. Dry hole. }\end{array}$ \\
\hline
\end{tabular}

Richards well No. 1.

\begin{tabular}{|c|c|c|c|c|c|c|}
\hline White Plains Oil & $\begin{array}{l}\text { North Petroleum } \\
\text { pool. }\end{array}$ & 686 & 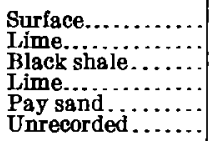 & $\begin{array}{c}21 \\
91 \\
33 \\
25 \\
7.5 \\
10\end{array}$ & $\begin{array}{r}21 \\
112 \\
145 \\
170 \\
177 ! \\
187 \frac{1}{2}\end{array}$ & $\begin{array}{l}\text { Reported initial } \\
\text { production, } 100 \\
\text { barrels. }\end{array}$ \\
\hline
\end{tabular}

Richards well No. 2.

\begin{tabular}{|c|c|c|c|c|c|c|}
\hline $\begin{array}{l}\text { White Ploins Oil } \\
\text { \& Gas Co. }\end{array}$ & $\begin{array}{l}\text { North Petroleum } \\
\text { pool. }\end{array}$ & 718 & 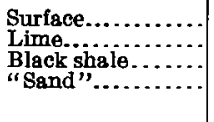 & $\begin{array}{r}13 \\
139 \\
39 \\
69\end{array}$ & $\begin{array}{r}13 \\
152 \\
190 \\
253\end{array}$ & $\begin{array}{l}\text { First oil at } 212 \text { feet, } \\
\text { second at } 238 \\
\text { feet. Reported } \\
\text { initial produc- } \\
\text { tion, } 275 \text { barrels. }\end{array}$ \\
\hline
\end{tabular}

Richards well No. 3.

\begin{tabular}{|c|c|c|c|c|c|c|}
\hline $\begin{array}{l}\text { White Plains Oil } \\
\text { \& Gas Co. }\end{array}$ & $\begin{array}{l}\text { North Petroleum } \\
\text { pool. }\end{array}$ & 648 & $\begin{array}{l}\text { Surface.......... } \\
\text { Lime. } \\
\text { Black shale....... } \\
\text { Sand and lime.... }\end{array}$ & $\begin{array}{r}9 \\
67 \\
39 \\
73\end{array}$ & $\begin{array}{r}9 \\
76 \\
115 \\
188\end{array}$ & $\begin{array}{l}\text { Crevice and heavy } \\
\text { fow of water at } \\
153 \text { feet, show of } \\
\text { oil at } 160 \text { feet, } \\
\text { more water at } \\
170 \text { feet, and more } \\
\text { oil at 195 feet. } \\
\text { Reported initial } \\
\text { production, } 250 \\
\text { barrels. }\end{array}$ \\
\hline
\end{tabular}

Rush well No. 1.

\begin{tabular}{|c|c|c|c|c|}
\hline$\underset{\text { Dixon. }}{\text { Huntsman }}$ & $\begin{array}{l}11 \text { miles west of } \\
\text { Scottsville. }\end{array}$ & $\begin{array}{l}\text { Shale. } \\
\text { Lime, hard........ } \\
\text { Lime, soft........ } \\
\text { Oil sand, show of } \\
\text { "amber oil." } \\
\text { Lime and shale.... } \\
\text { Black shale. } \\
\text { Cap rock........... } \\
\text { Sand, dry ......... } \\
\text { Lime and sand.... } \\
\text { Shale, bluish green }\end{array}$ & $\begin{array}{r}45 \\
40 \\
55 \\
4 \\
68 \\
48 \\
8 \\
6 \\
130 \\
1\end{array}$ & $\begin{array}{r}45 \\
85 \\
140 \\
144 \\
\\
212 \\
260 \\
268 \\
274 \\
404 \\
405\end{array}$ \\
\hline
\end{tabular}


Records of wells in Allen County, Ky.-Continued.

Stamp well No. 1.

\begin{tabular}{|c|c|c|c|c|c|c|}
\hline \multirow{2}{*}{$\begin{array}{l}\text { Owner or source } \\
\text { of information. }\end{array}$} & \multirow{2}{*}{ Location. } & \multirow{2}{*}{$\begin{array}{l}\text { Alti- } \\
\text { tude. }\end{array}$} & \multicolumn{3}{|c|}{ Driller's log. } & \multirow{2}{*}{ Remarks. } \\
\hline & & & Formation. & $\begin{array}{c}\text { Thick- } \\
\text { ness. }\end{array}$ & Depth. & \\
\hline 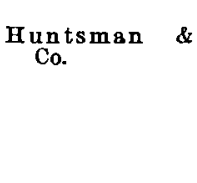 & $\begin{array}{l}11 \text { miles north of } \\
\text { Chapel Hill. }\end{array}$ & $\begin{array}{l}\text { Feet. } \\
\text { Fe. }\end{array}$ & 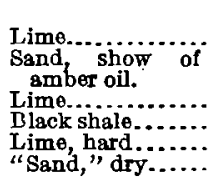 & $\begin{array}{r}\text { Feet. } \\
124 \frac{1}{2} \\
2 \\
21 \\
48 \\
6 \\
37\end{array}$ & $\begin{array}{c}\text { Feet. } \\
124 \\
1262 \\
129 \\
177 \\
183 \\
220\end{array}$ & \\
\hline
\end{tabular}

Tabos well No. 1.

\begin{tabular}{|c|c|c|c|c|c|c|}
\hline $\begin{array}{l}\text { White Plains Oil } \\
\text { \& Gas Co. }\end{array}$ & $\begin{array}{l}11 \text { miles northeast } \\
\text { of Halifax. }\end{array}$ & $\ldots \ldots$ & 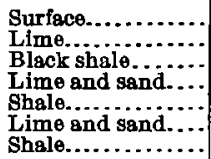 & $\begin{array}{r}22 \\
350 \\
46 \\
56 \\
9 \\
40 \\
\text { at }\end{array}$ & $\begin{array}{r}22 \\
372 \\
418 \\
474 \\
483 \\
523 \\
523\end{array}$ & $\begin{array}{l}\text { Dry hole. Bottom } \\
\text { of "Corniferous" } \\
\text { limestone prob- } \\
\text { ably at } 474 \text { feet. }\end{array}$ \\
\hline
\end{tabular}

Tucker well No. 1.

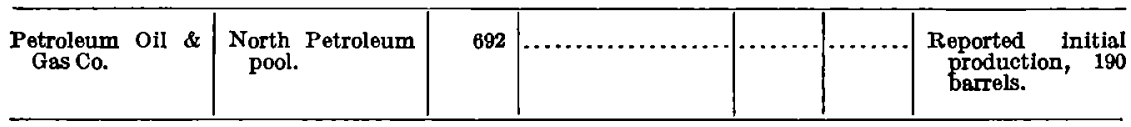

Tucker well No. 2.

\begin{tabular}{|c|c|c|c|c|c|c|}
\hline $\begin{array}{l}\text { Petroleum Oil \& } \\
\text { Gas Co. }\end{array}$ & $\begin{array}{l}\text { North Petroleum } \\
\text { pool. }\end{array}$ & 700 & $\begin{array}{l}\text { Lime.............. } \\
\text { Black shale..... } \\
\text { Lime and sand... }\end{array}$ & $\begin{array}{c}125 \\
44 \\
962\end{array}$ & $\begin{array}{l}125 \\
169 \\
265 \frac{1}{2}\end{array}$ & $\begin{array}{l}\text { Reported initial } \\
\text { production, } 125 \\
\text { barrels. }\end{array}$ \\
\hline
\end{tabular}

Tucker well No. 3.

\begin{tabular}{|c|c|c|c|c|c|c|}
\hline $\begin{array}{l}\text { Petroleum Oil \& } \\
\text { Gas Co. }\end{array}$ & $\begin{array}{l}\text { North Petroleum } \\
\text { pool. }\end{array}$ & 707 & $\begin{array}{l}\text { Lime............. } \\
\text { Black shale........ } \\
\text { Lime.............. } \\
\text { Pay sand.......... }\end{array}$ & $\begin{array}{c}135 \\
423 \\
54 \\
4\end{array}$ & $\begin{array}{l}135 \\
177 \frac{1}{2} \\
231 \\
235 \frac{1}{2}\end{array}$ & $\begin{array}{l}\text { Reported initial } \\
\text { production, } 300 \\
\text { barrels. }\end{array}$ \\
\hline
\end{tabular}

Tucker well No. 4.

\begin{tabular}{l|r|r|l|r|r|r}
\hline $\begin{array}{c}\text { Petroleum Oil \& } \\
\text { Gas Co. }\end{array}$ & $\begin{array}{l}\text { North Petroleum } \\
\text { gool. }\end{array}$ & 632 & $\begin{array}{l}\text { Lime............... } \\
\text { Black shale...... } \\
\text { Total depth not } \\
\text { known. }\end{array}$ & 44 & 101 & 57 \\
\hline
\end{tabular}

Tucker well No. 5 .

\begin{tabular}{l|l|r|l|r|r|r}
\hline $\begin{array}{c}\text { Petroleum on \& } \\
\text { Gas Co. }\end{array}$ & $\begin{array}{l}\text { North Petroleum } \\
\text { pool. }\end{array}$ & 682 & $\begin{array}{l}\text { Lime.................. } \\
\text { Black shale....... } \\
\text { Total depth not } \\
\text { known. }\end{array}$ & $\begin{array}{r}103 \\
44\end{array}$ & $\begin{array}{r}103 \\
147\end{array}$ \\
\hline
\end{tabular}


Records of wells in Allen County, Ky.-Continued.

Walker well No. 1 .

\begin{tabular}{|c|c|c|c|c|c|c|}
\hline \multirow{2}{*}{$\begin{array}{l}\text { Owner or source } \\
\text { of information. }\end{array}$} & \multirow[b]{2}{*}{ Location. } & \multirow{2}{*}{$\begin{array}{l}\text { Alti- } \\
\text { tude. }\end{array}$} & \multicolumn{3}{|c|}{ Driller's log. } & \multirow[b]{2}{*}{ Remarks. } \\
\hline & & & Formation. & $\begin{array}{l}\text { Thick- } \\
\text { ness. }\end{array}$ & Depth. & \\
\hline Ocala Oil Co...... & $\begin{array}{l}2 \text { miles northwest } \\
\text { of Scottsville. }\end{array}$ & Feet. & $\begin{array}{l}\text { Lime......... } \\
\text { Black shale....... } \\
\text { Cap rock........ } \\
\text { Lime, sandy dark } \\
\text { gray. } \\
\text { Lime, brown, show } \\
\text { of oil. } \\
\text { Shale, sandy...... } \\
\text { Lime and brown } \\
\text { "sand balls" } \\
\text { with strong odor } \\
\text { of oil. } \\
\text { shale, mu d d y } \\
\text { dark. } \\
\text { s h ale, s a n d y } \\
\text { dark. } \\
\text { shale, mu d d y } \\
\text { dark., } \\
\text { "Sand," white } \\
\text { water. }\end{array}$ & $\begin{array}{r}\text { Feet. } \\
127 \\
50 \\
4 \\
20 \\
12 \\
12 \\
8 \\
\\
12 \\
8 \\
17 \\
2\end{array}$ & $\begin{array}{r}\text { Feet. } \\
127 \\
177 \\
181 \\
201 \\
213 \\
225 \\
233 \\
\\
245 \\
253 \\
270 \\
272\end{array}$ & $\begin{array}{l}\text { Abandoned. Bot- } \\
\text { tom of "Cornif- } \\
\text { erous" limestone } \\
\text { probably at } 233 \\
\text { feet. }\end{array}$ \\
\hline
\end{tabular}

Watkins well No. 1.

\begin{tabular}{|c|c|c|c|c|c|c|}
\hline $\begin{array}{l}\text { White Plains Oil } \\
\text { \& Gas Co. }\end{array}$ & $\begin{array}{l}\text { mile west of Hali- } \\
\text { fax. }\end{array}$ & & $\begin{array}{l}\text { Surface............. } \\
\text { Lime. } \\
\text { Black shale........ } \\
\text { Sand and lime.... }\end{array}$ & $\begin{array}{r}20 \\
257 \\
49 \\
70\end{array}$ & $\begin{array}{r}20 \\
277 \\
326 \\
396\end{array}$ & $\begin{array}{l}\text { Gas at } 110 \text { feet. No } \\
\text { oil. Well aban- } \\
\text { doned. }\end{array}$ \\
\hline
\end{tabular}

J. I. Williams well No. 1.

\begin{tabular}{|c|c|c|c|c|c|}
\hline $\begin{array}{l}\text { White Plains Oil } \\
\text { \& Gas Co. }\end{array}$ & $\begin{array}{l}{ }^{31} \text { miles west of } \\
\text { Scottsville. }\end{array}$ & $\begin{array}{l}\text { Surface........... } \\
\text { Lime.......... } \\
\text { Black shale...... } \\
\text { Lime and sand... }\end{array}$ & $\begin{array}{r}16 \\
164 \\
50 \\
133\end{array}$ & $\begin{array}{r}16 \\
180 \\
230 \\
363\end{array}$ & $\begin{array}{l}\text { Gas at } 300 \text { feet. } \\
\text { No oil. } \mathrm{H} \text { ol } \\
\text { plugged. }\end{array}$ \\
\hline
\end{tabular}

\section{NOTES ON ADJOINING COUNTIES.}

The activity in Allen County at each stage in the development of its petroleum resources was accompanied by more or less prospecting in adjoining counties, especially those toward the south, west, and north. As a result good showings of oil were discovered in the central part of Barren County and scattered small showings of both oil and gas in other places. Oil was also found along the east border of Monroe County to the east, and a pipe line was laid to this district from Wayne County, 30 or 40 miles farther east.

Although it was not practicable to give much time to the study of the six counties which border Allen County, reconnaissance trips were made into five of them, and all available information concerning recent development in each was obtained. In spite of the fragmentary nature of the known data it is thought best to append the following notes to this report.

\section{BARREN COUNTY, KY.}

Barren County is northeast of Allen County. Its county seat, Glasgow, a town of 2,316 population in 1910 , is reached by a branch line of the Louisville \& Nashville Railroad from Glasgow Junction. The general northeast strike of the formations in this part of Kentucky 
results in a nearly perfect duplication of the geologic features in the two counties. The central portion of Barren County is underlain by the St. Louis limestone and older Mississippian strata very similar in all respects to those in Allen County. Toward the southeast the black shale and subjacent rocks are exposed in the valleys of the larger streams. Toward the northwest, above the St. Louis, occur the Ste. Genevieve limestone and younger Chester formations.

The structure is in general, therefore, that of an extensive monocline dipping toward the northwest, but there is every reason to believe that the monocline is modified by gentle flexures similar to the small domes which have evidently controlled so largely the accumulation of oil in Allen County.

Orton ${ }^{1}$ says that the largest oil field in the western half of Kentucky at the time his report was prepared was that of Barren County, though compared with other oil fields it was small. There were also a few wells producing gas, and new fields or extensions of the known field were being sought with vigor. The first oil found in this county is said to have been an oil spring $4 \frac{1}{2}$ miles southeast of Glasgow, and the first well was drilled near the spring shortly after the Civil War. Other wells were drilled not long after, and some of them are said to have flowed, one producing 100 barrels of oil a day. The production of the field, although low, continued almost without interruption from 1866 to 1890 . Orton ${ }^{2}$ states that the oil is black and that its specific gravity is $40^{\circ}$ to $42^{\circ} \mathrm{B}$. It does not contain an excessive amount of sulphurous compound and in fact is not offensive by reason of the presence of such substances unless the process of distillation is pushed too far. The oil is derived from a stratum that lies about 170 feet below the valley level and the top of the sand is 30 to 40 feet below the bottom of the black shale. From a comparison of the well Jogs with sections exposed on the side of the Nashville dome a short distance south in Tennessee, Orton infers that the oil sand is of Clinton age, though, as he says, the evidence is not conclusive. $\mathrm{He}$ makes the following estimate of the production of the field:

Estimated production of oil in Barren County, Ky., from 1872 to 1888.

Barrels.

Barrels.

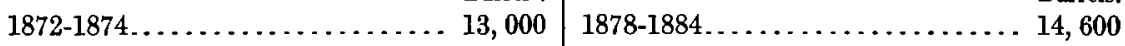

$1874-1876 \ldots \ldots \ldots \ldots \ldots \ldots \ldots .7,300 \quad 1884-1888 \ldots \ldots \ldots \ldots \ldots \ldots \ldots, 4,400$

$1876-1878 \ldots \ldots \ldots \ldots . . . \ldots . . .6,600$

The oil is treated on the premises in a crude way, about 55 per cent of distillate being obtained from it. This distillate can be burned in the condition in which it comes from the stills and a small quantity of it is so used in the immediate neighborhood; but it is mainly shipped to Louisville for further treatment including bleaching and deodorizing. ${ }^{2}$

1 Orton, Edward, Report on the occurrence of petroleum, natural gas, and asphalt rock in western Kentucky, based on examinations made in 1888 and 1889: Kentucky Geol. Survey, p. 149 [1891?].

2 Idem, p. 150 .

Idem, p.153. 
Between 1889 and 1891 there was renewed activity in the Barren County field which resulted in considerable increase in production and the building of a refinery. Since that time, however, the production has gradually fallen off.

At the time the field work for the present report was done, in April, 1917 , the oil production of Barren County was confined to a small group of wells on Boyds Creek, $3 \frac{1}{2}$ miles south of Glasgow. The original well was drilled in 1865 and is reported to have yielded 25 barrels a day for 17 years by pumping. The surface of the black shale is 50 feet below the creek level, and the oil "sands" are found between 15 and 30 feet below the bottom of the shale. A typical log is that of a well drilled late in 1916 on a hillside about 65 feet abova the creek:

Record of Oskamp well on Boyds Creek, Barren County, $K y$.

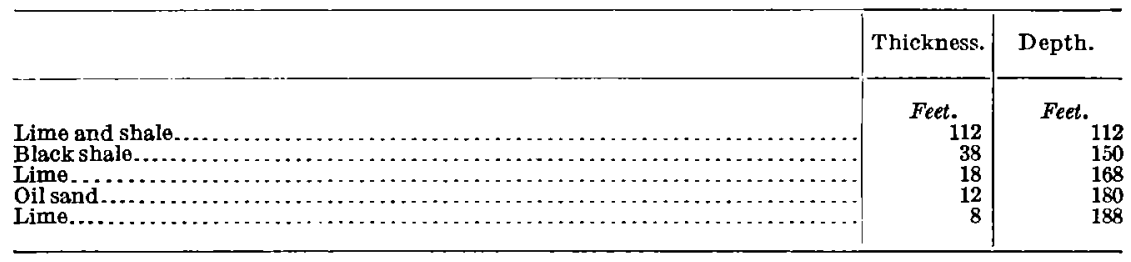

Three-fourths of a mile due north from the group of wells on Boyds Creek there is a dry hole at an elevation about 50 feet higher than the level of the creek in the vicinity of the producing wells. The surface of the black shale was reached at a depth of 160 feet, indicating a strong dip away from the oil field toward the north. Another well, $1 \frac{1}{2}$ miles down the creek, which flows in a general southerly direction, was drilled in the valley flat and reached the black shale at 48 feet. As the stream falls 25 or 30 feet in this distance it is evident that the surface of the black shale likewise dips toward the south. In all probability the Boyds Creek oil field is situated on or near the summit of a small anticline.

In all the wells on Boyds Creek there is a show of amber oil in the limestone just above the black shale, but the production is entirely from the sands beneath that horizon. No data are at hand to indicate whether the pay is in the "Corniferous" or the Silurian limestone.

At the present time seven wells are being pumped and yield a total production of 10 or 12 barrels a day. The oil is conveyed by pipe lines to Glasgow and thence shipped in tank cars to refineries at Louisville or Nashville. Enough gas is obtained from one of the wells to operate the pumps and drills.

Another oil pool has been discovered beneath the valley of Beaver Creek, 3 miles north of Glasgow, but had not become a steady producer in April, 1917. The uplands on either side of Beaver Creek $77677^{\circ}-19-$ Bull. $688-8$ 
are underlain by St. Louis limestone, but strata of Warsaw age outcrop a few feet above the creek level, so that the depth of the black shale below the valley bottom is probably between 200 and 250 feet.

On the Austin farm are three wells. No. 1 is 500 feet deep and passed through two oil sands and one gas sand. Gas from this well is piped to the neighboring farm home. No. 2 is 30 feet from No. 1 and is 221 feet deep. An oil sand was entered at 198 feet and yields amber oil of a high grade. The well flows one or two barrels of oil a day, but had not been systematically pumped. No. 3, like No. 2, does not penetrate the black shale but taps a good reservoir of amber oil at about 200 feet. It would probably pump five barrels a day.

Half a mile below Beaver Creek, toward the southwest, there are four wells on the Harrison farm, from which a fow barrels of oil are occasionally pumped for local use. These wells are about 425 feet deep, but no reliable figures could be obtained as to the depth below the black shale at which the oil sands were penetrated. A mile below the Harrison farm two wells have been drilled on the Weiniger lease and a third was being drilled in April, 1917. These wells, likewise, are over 400 feet deep and are reported to have a good show of dark-green oil from sands below the black shale. Half a mile upstream from the Austin farm there is a gas well on the Duff lease which is reported to be capable of yielding a million feet of gas from sands which were struck at a depth of 400 feet.

\section{WARREN COUNTY, KY.}

Warren County is west of Barren County and northwest of Allen County. Its county seat is Bowling Green, a city of 9,597 people in 1910. Because of the general northwest dip of the strata the formations that outcrop within its boundaries are, in the main, younger than those in Allen County and range from the uppermost Warsaw through the St. Louis, Ste. Genevieve, and overlying Chester to the Pottsville group. The geology of the county was mapped in 1891 by Hoeing, and this map, with some revision, is reproduced on a smaller scale in Plate X. Mr. Hoeing, for several years State geologist of Kentucky, kindly furnishes the following statement concerning the geology of the county:

There is an average dip, measured on top of the black shale, of about 28 feet to the mile from Petroleum station to the gas wells on Drakes Creek east of Bowling Green. From the gas wells to the mouth of Gasper River there is an average dip of 40 feet to the mile. In the portion of Warren County included in the Little Muddy quadrangle there is a dome whose summit is near the southeast corner of the Little Muddy quadrangle. This dome dips to the vest, northwest, and north toward Barren and Gasper rivers at the rate of 30 to 40 feet to the mile, and it there extends approximately along the southern edge of the Little Muddy quadrangle, an anticline, which crosses Gasper River and extends probably into Butler County. In the same way 


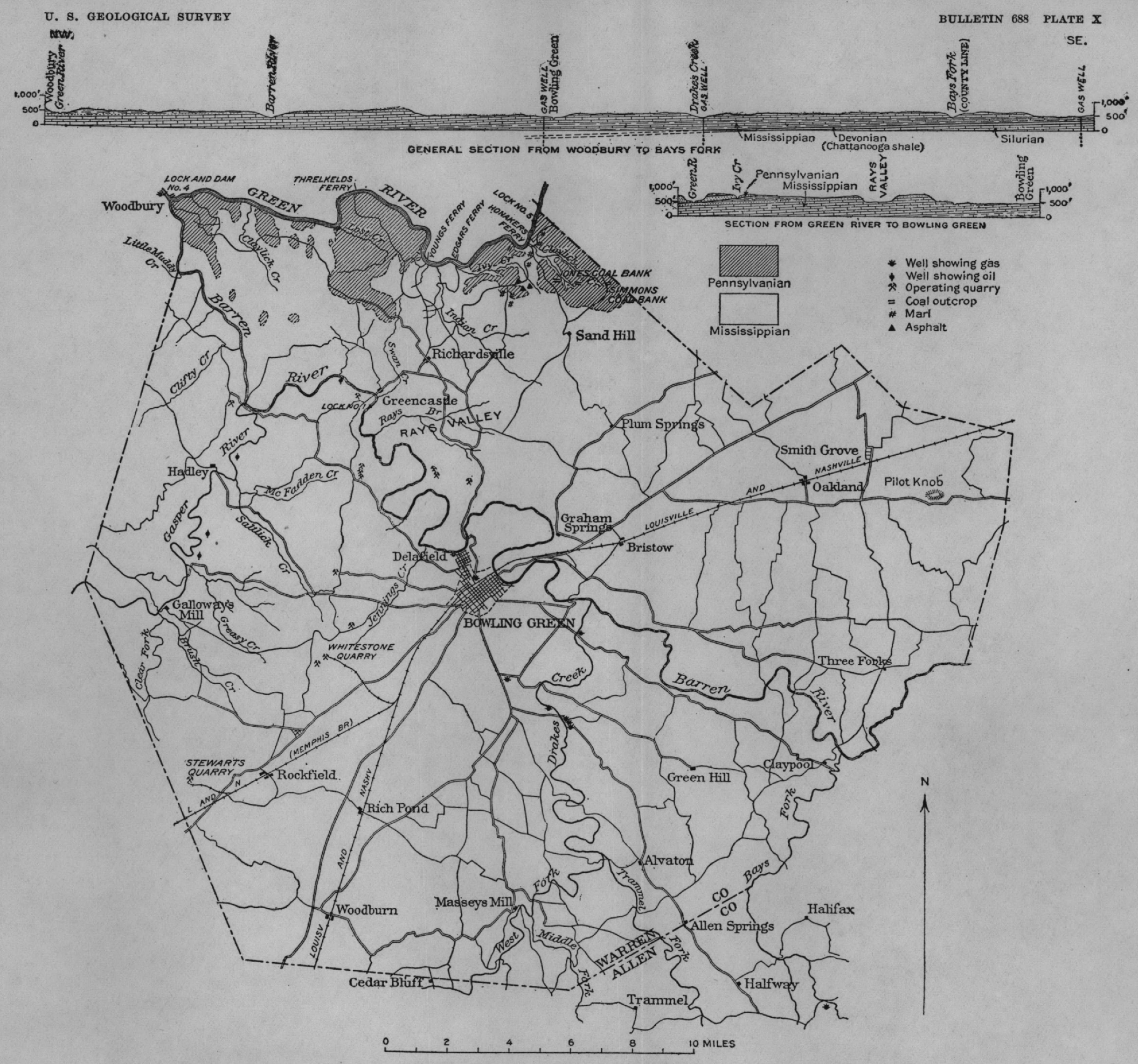

GEOLOGIC MAP OF WARREN COUNTY, KY.

Reproduced with some modifications from a map prepared in 1891. 


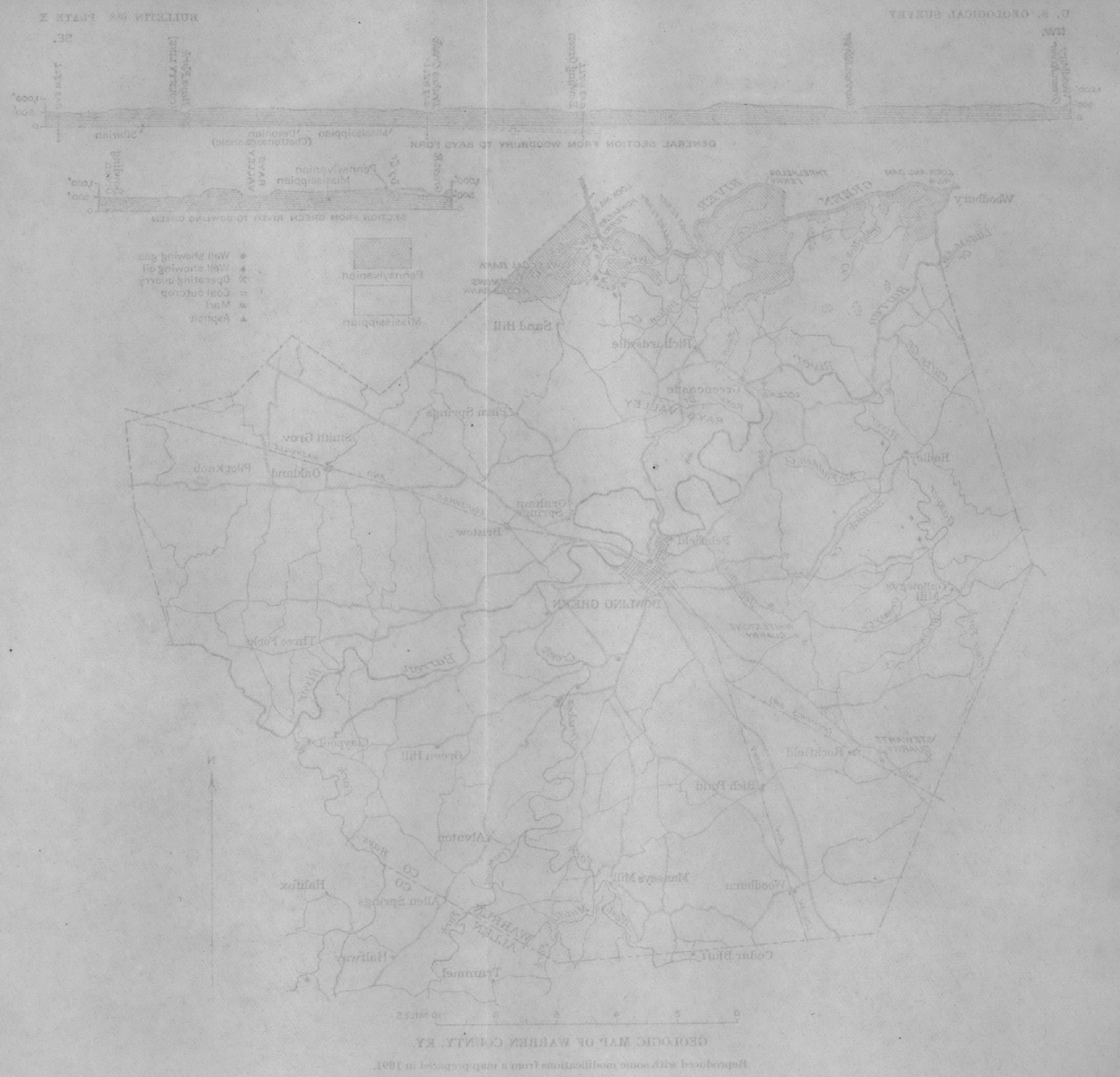


another anticline runs out from the dome near the mouth of Gasper River and on down on the north side of Big Barren River. Between these two anticlines and to the east of the one at the mouth of the Gasper there is a terrace-like structure at the foot of the dome, and from the west and north sides of this terrace the dips range from 75 to 150 feet to the mile. This terrace structure roughly follows the line of Gasper and Big Barren rivers, the steepest dip being just north of Big Barren River. These dips continue to the northwest, with possibly some reversal, bringing down the Pottsville before the mouth of Big Barren River is reached.

There is some testing for oil being done, but it is very slow, as only one company is doing any work, although all of the territory has been leased.

Although shows of both gas and oil have been found in several places, no pool of any size has been discovered. At the present time most of the interest is directed toward work in the far western part of the county.

The Chenault Oil \& Gas Co. have drilled two wells since January, 1917, which penetrate the deeper strata in Warren County, and are now drilling a third. Their first test was on the Higgenbotham farm, 9 miles northwest of Bowling Green, 1 mile west of Browns Lock, on Barren River. The well had a good showing of oil but was abandoned without shooting.

Record of Higgenbotham well No. 1, Warren County, Ky.

\begin{tabular}{|c|c|c|}
\hline & Thickness. & Depth. \\
\hline & Feet. & Feet. \\
\hline 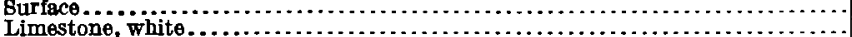 & $\begin{array}{l}28 \\
27\end{array}$ & 28 \\
\hline $\begin{array}{l}\text { Limestone, white. } \\
\text { Limestone, yellow }\end{array}$ & 27 & $\begin{array}{l}55 \\
63\end{array}$ \\
\hline 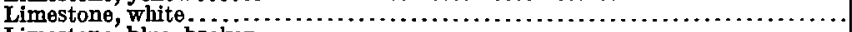 & 199 & 262 \\
\hline Limestone, blue, broken. . . . . . . . . . . . & 20 & 282 \\
\hline 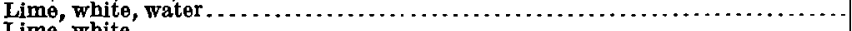 & 48 & 330 \\
\hline 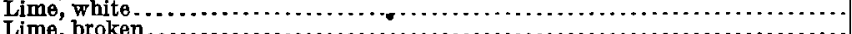 & $\begin{array}{r}59 \\
25\end{array}$ & 389 \\
\hline 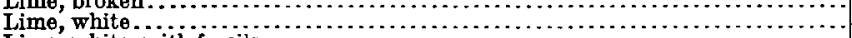 & $\mathbf{6 4}$ & $\begin{array}{l}414 \\
478\end{array}$ \\
\hline 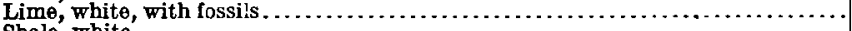 & 8 & 486 \\
\hline 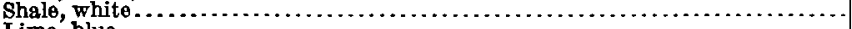 & 33 & 519 \\
\hline 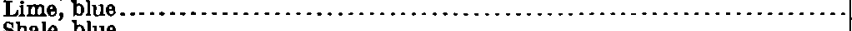 & 17 & 536 \\
\hline $\begin{array}{l}\text { Shale, blue } \\
\text { Lime, blue }\end{array}$ & $\begin{array}{l}49 \\
79\end{array}$ & 58.5 \\
\hline Fossils at 619 feet. & 72 & 657 \\
\hline $\begin{array}{l}\text { Shale blue } \ldots \text { zossils at } 708 \text { leet. } \\
\quad \text { Fon }\end{array}$ & 69 & 726 \\
\hline 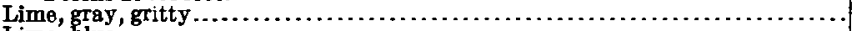 & 13 & 739 \\
\hline 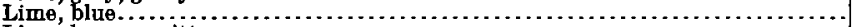 & 13 & 752 \\
\hline 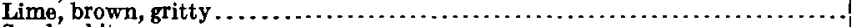 & 16 & 768 \\
\hline 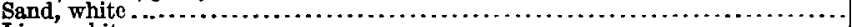 & 29 & 797 \\
\hline 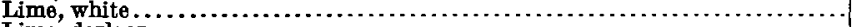 & 93 & 890 \\
\hline 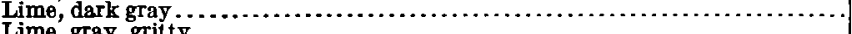 & 8 & \\
\hline 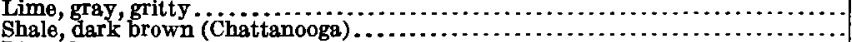 & $\begin{array}{r}2 \\
107\end{array}$ & $\begin{array}{r}900 \\
1,007\end{array}$ \\
\hline 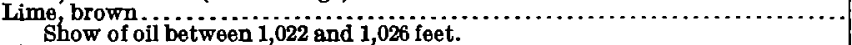 & 22 & 1,029 \\
\hline 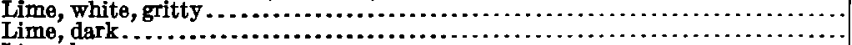 & $\begin{array}{r}6 \\
21\end{array}$ & $\begin{array}{l}1,035 \\
1,056\end{array}$ \\
\hline $\begin{array}{l}\text { Lime, brown } \\
\text { Show of ofl between } 1,062 \text { and } 1,066 \text { feet. } \\
\text { Show of oil between } 1,091 \text { and } 1,096 \text { feet. }\end{array}$ & 45 & 1,101 \\
\hline 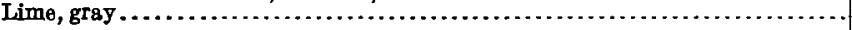 & 15 & 1,116 \\
\hline
\end{tabular}


The second well drilled by the Chenault Oil \& Gas Co. was on the Robert Hurd farm on Gasper River near Hadley, in the western part of Warren County. Shows of oil were found at two levels; the well was shot, but the result was only to increase the flow of salt water. The records of this and the preceding well were furnished by Col. M. W. Crump, of Bowling Green.

Record of Robert Hurd well (Chenault No. 2), Warren County, Ky.

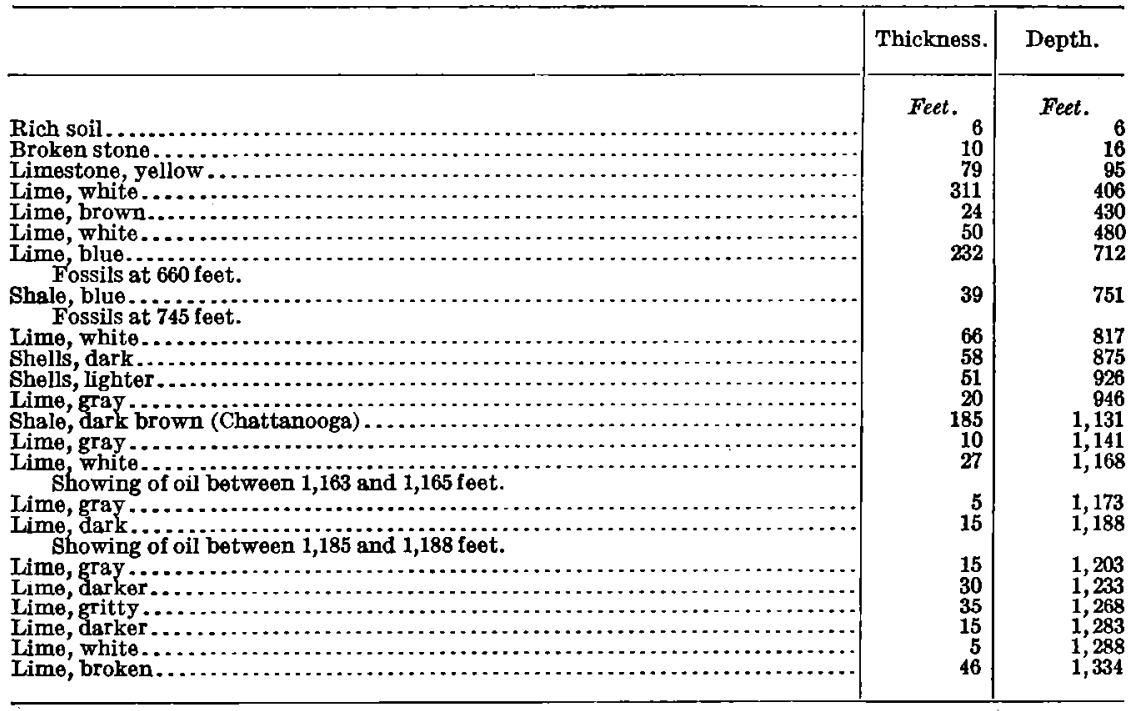

Another well in the same part of the county was completed in May, 1917, on the Willey farm near Gasper-River, $9 \frac{1}{2}$ miles west of Bowling Green and $3 \frac{1}{2}$ miles south of Hadley. The following log was supplied by L. S. Howchin: 
Record of Willey well No. 1, Warren County, Ky.

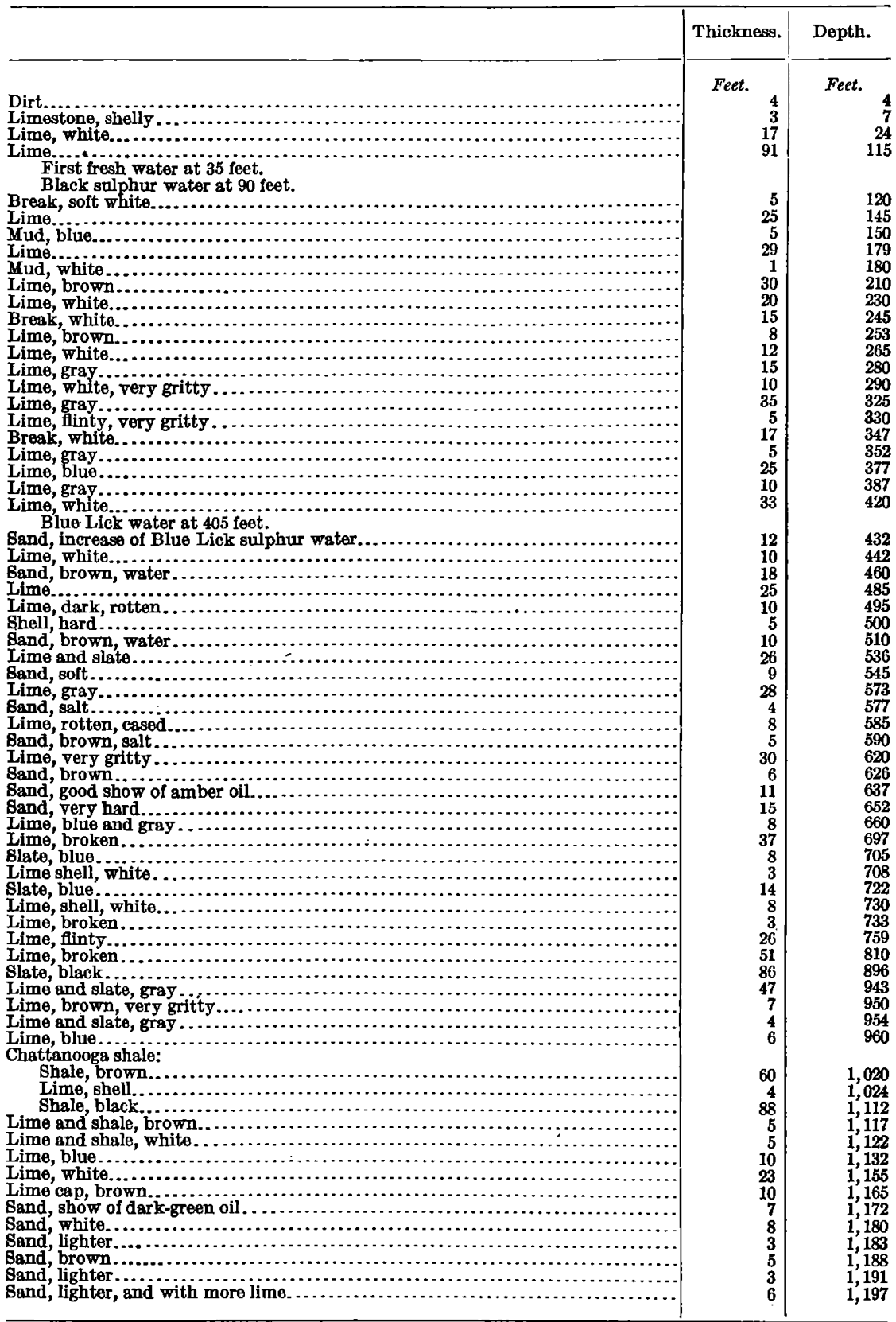

Total depth, 1,197 feet. 


\section{SDMPSON COUNTY, KY.}

Simpson County is south of Warren and west of Allen; its county seat, Franklin, in 1910 had a population of 3,063. The surface of the county has slight relief. The greater part of the area is underlain by strata of St. Louis and Ste. Genevieve age, but toward the southeast and east the larger streams have cut their valleys. down into the underlying Warsaw beds. Monadnocks, such as Pilot Knob, rise above the general surface of the upland west and northwest of Franklin. They are composed of limestones and sandstones of Chester age and represent residual remnants of those rocks which were once widespread over the area.

The general structural conditions in Simpson County are similar to those in Allen and Warren counties. The regional dip is toward the northwest, and there is great probability that it is modified in some localities by gentle domelike flexures favorable for the accumulation of oil. As in Warren County, the general dip carries the "Corniferous" and Silurian limestones far below the surface in the northwestern part of the county, and the thickening of the Mississippian strata in that direction tends to carry them still farther below the surface.

Prospecting for oil has been carried on intermittently during the last half century, and fair showings of oil have been observed in a number of wells, but no productive pool has been discovered in the county. Oil seeps are common and many water wells in the district 4 or 5 miles east of Franklin have been ruined by them. Other shallow wells in the same locality have tapped small reservoirs of gas. It is said that in May, 1917, about 50,000 acres in Simpson County were under lease for oil and gas development.

Among the wildcat wells in Simpson County there are only a few concerning which accurate data are now available. In 1903 a hole was drilled to a depth of 1,500 feet 3 miles east of Franklin. A fair showing of oil was found just below the black shale and also near the bottom of the hole, which must have penetrated the "Trenton" limestone. At about the same time a 600-foot hole was drilled in the eastern part of the county, 2 miles south of the middle Scottsville pike and about a mile west of the Simpson-Allen county line. No oil was found.

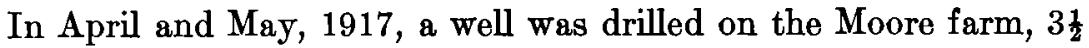
miles east of Franklin. The surface of the black shale was reached at 450 feet, and small shows of oil and several pockets of gas were found above the shale. 


\section{SUMAER COUNTY, TENN.}

Sumner County is in Tennessee, south of Simpson and Allen counties, $\mathrm{Ky}_{\text {.; }}$ the county seat is Gallatin, a town of 2,399 people in 1910. The county is traversed from west to east by the Highland Rim, which overlooks the Nashville basin toward the south and separates the upland underlain by Mississippian rocks, which stretches northward into Kentucky, from the lower area of Ordovician strata, which occupies the greater part of middle Tennessee.

The exposures along the streams flowing southward from the divide along the Highland Rim give an excellent idea of the rocks underlying the black shale in southern Kentucky. The section adjacent to the Jackson Highway near Bransford, Tenn., has been described in the discussion of the Ordovician and Silurian beds (p. 39).

The automobile road follows the valley of Bledsoe Creek and crosses the horizon of the Chattanooga shale 7.7 miles south of the KentuckyTennessee State line. At this locality there is a thin stratum 8 feet below the top of the black shale which presents unusual features. The thin bed, one-half to 1 inch thick, is composed of dark-brown or black sand grains and pebbles with numerous fragments of fossilized plant and animal organisms. Many of the sand grains and pebbles are phosphatic, and the layer gives off a strong bituminous odor when broken. The bed presents all the characteristics of a residual deposit indicative of erosional unconformity. The black shale above this zone is horizontal, that below it has a variable dip, which in one place attains a maximum of $8^{\circ} \mathrm{S}$. The lower beds are less evenly laminated and generally are thicker than the upper.

A number of deep holes have been drilled in Sumner County at different times since the development of the petroleum resources of Allen County was begun, but no producing wells have been completed.

Two wells were drilled at South Tunnel, 8 miles north of Gallatin, in the spring of 1917. The logs of these wells have been supplied by I. J. Brown and T. W. Addington. The first was a dry hole, and the second resulted in only a small showing of oil.

Record of G. M. Saunders well No. 1, South Tunnel, Tenn.

\begin{tabular}{|c|c|c|}
\hline & Thickness. & Depth. \\
\hline 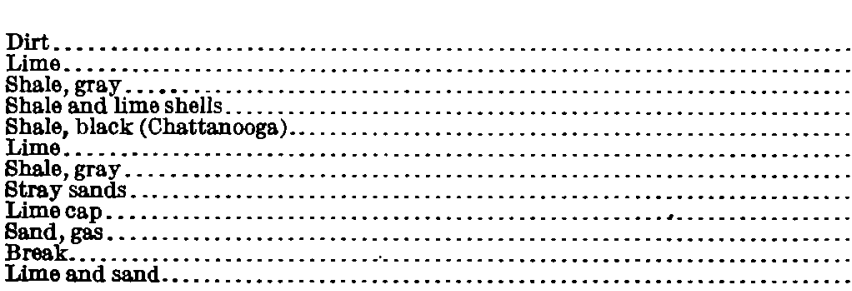 & $\begin{array}{r}\text { Feet. } \\
20 \\
85 \\
30 \\
27 \\
27 \\
6 \\
3 \\
10 \\
3 \\
24 \\
12 \\
371\end{array}$ & $\begin{array}{r}\text { Feet. } \\
20 \\
105 \\
135 \\
162 \\
189 \\
195 \\
198 \\
208 \\
211 \\
235 \\
247 \\
618\end{array}$ \\
\hline
\end{tabular}


Record of G. M. Saunders well No. 2, South Tunnel, Tenn.

\begin{tabular}{|c|c|c|}
\hline • & Thickness. & Depth. \\
\hline 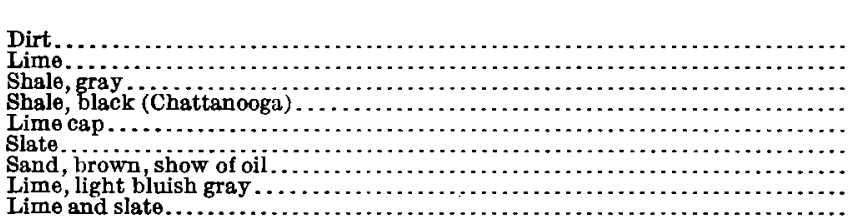 & $\begin{array}{r}\text { Feet. } \\
3 \\
108 \\
27 \\
36 \\
6 \\
3 \\
14 \\
10 \\
43\end{array}$ & $\begin{array}{r}\text { Feet. } \\
111 \\
138 \\
174 \\
180 \\
183 \\
197 \\
207 \\
250\end{array}$ \\
\hline
\end{tabular}

MACON COUNTY, TENN., AND MONROE COUNTY, KY.

Macon County is in Tennessee, south of Allen County, $\mathrm{K}_{\mathbf{y}}$, and east of Sumner County, Tenn.; Monroe County is in Kentucky, east of Allen County and southeast of Barren County. There is no railroad in either county, and no drilling for oil or gas has been reported in that portion of their area which adjoins Allen County.

There can be no doubt but that a considerable area in each of these counties is underlain by the oil-bearing limestones beneath the black shale, and the conclusion is justifiable that structural conditions similar to those in the producing oil fields of Allen County are present in these areas to the southeast and east. It should be noted, however, that prospecting for oil in those areas should not be attempted near or south of the Highland Rim in Macon County nor in the vicinity of Barren River in Monroe County.

A well recently drilled just south of Macon County furnishes information of value concerning the strata that underlie this district. 
Log of well on W. Hart Reaves farm, 1 mile southwest of Hartsville, Tenn.

[Drilled with cable tools Dec. 4 to May 10, 1918. Log made up by Charles Butts from samples transmitted by W. Hart Reaves. Notes in quotation marks are from driller's log.]

\begin{tabular}{|c|c|c|c|}
\hline $\begin{array}{l}\text { No. of } \\
\text { sample. }\end{array}$ & Character of strata. & $\begin{array}{l}\text { Thick- } \\
\text { ness. }\end{array}$ & Depth. \\
\hline & & Feet. & Feet. \\
\hline $\begin{array}{l}1 \\
2\end{array}$ & 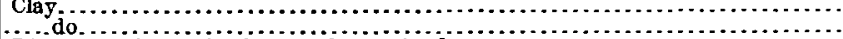 & $\begin{array}{l}27 \\
20\end{array}$ & $\begin{array}{l}27 \\
47\end{array}$ \\
\hline 3 & $\begin{array}{l}\text { Limestone, light bluish gray, fne grain } \\
\text { Limestone like No. } 3 \text {; ostracodes (?)... }\end{array}$ & $\begin{array}{l}18 \\
20\end{array}$ & $\begin{array}{l}65 \\
85\end{array}$ \\
\hline 5 & $\begin{array}{l}\text { Limestone like No. } 3 \text { drillings mostly powder; a few small pieces with fine } \\
\text { striae; orthoids or strophomenoids } . . . \ldots \ldots \ldots \ldots \ldots \ldots \ldots \ldots\end{array}$ & 20 & 105 \\
\hline 6 & $\begin{array}{l}\text { Limestone mostly drab or dove-colored; near lithographic texture; conch } \\
\text { fracture; some dark-gray, fne-grained, less light, flaky material....... }\end{array}$ & 10 & 115 \\
\hline 7 & Limestone like No. 3; a little darker $\ldots$ & 20 & 135 \\
\hline 8 & Limestone, light gray, fine grained; like & 20 & 155 \\
\hline 9 & Limestone like No. $7 \ldots \ldots \ldots \ldots \ldots \ldots$ & 20 & 175 \\
\hline 10 & $\begin{array}{l}\text { Uncertain } \\
\text { Limestone like No. } 7 ; \text { Rafinesquina. }\end{array}$ & $\begin{array}{r}15 \\
5\end{array}$ & $\begin{array}{l}190 \\
195\end{array}$ \\
\hline 12 & Uncertain. "Small amount of water a & 15 & 210 \\
\hline 13 & Limestone, light gray; powder (all pas & 5 & 215 \\
\hline 14 & 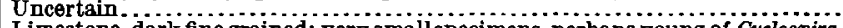 & 15 & 230 \\
\hline 15 & $\begin{array}{l}\text { Limestone, dark fine grained; very small specimens, perhaps young of Cyclospira } \\
\text { bisulcata of New York Trenton, seemingly comparable to no other Ordovician } \\
\text { form }\end{array}$ & & 235 \\
\hline & 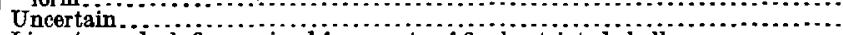 & $\mathbf{1 5}$ & 250 \\
\hline 17 & Limestone, dark fine-grained fragments of finely striated shells & $\mathbf{5}$ & 255 \\
\hline 18 & Uncertain. & 15 & 270 \\
\hline 19 & 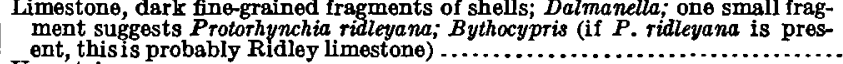 & 5 & 275 \\
\hline 20 & Uncertain & 15 & 290 \\
\hline $\begin{array}{l}21 \\
22\end{array}$ & $\begin{array}{l}\text { Light gray limest } \\
\text { Uncertain....... }\end{array}$ & $\begin{array}{r}5 \\
15\end{array}$ & 310 \\
\hline 23 & Limestone, light gray; drills to powder; "sh & 5 & 315 \\
\hline 24 & Uncertain...$\ldots \ldots \ldots \ldots \ldots \ldots \ldots$ & 15 & 330 \\
\hline $\mathbf{2 5}$ & Limestone, light gray; drills to powder; a little darker than No. 23 . & 5 & 335 \\
\hline 26 & Uncertain & 15 & 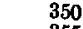 \\
\hline 27 & Limestone, drabbish gray..... . & 5 & 355 \\
\hline 28 & Uncertain ..... & 15 & $\begin{array}{l}370 \\
375\end{array}$ \\
\hline $\begin{array}{l}29 \\
30\end{array}$ & 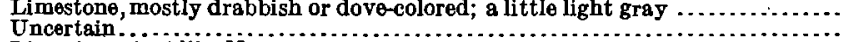 & $\mathbf{1 5}$ & 390 \\
\hline 31 & Limestone, just like No. $23 . \ldots \ldots \ldots \ldots \ldots \ldots \ldots \ldots$ & 5 & 395 \\
\hline 32 & Uncertain........ & 15 & 410 \\
\hline 33 & Limestone, dark & 5 & 415 \\
\hline $\mathbf{3 4}$ & Uncertain. & 15 & 430 \\
\hline 35 & Limestone, dark gray, fine grained. & 5 & 435 \\
\hline 36 & 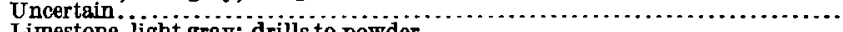 & 15 & 450 \\
\hline 37 & Limestone, light gray; drills to powder... & 5 & 455 \\
\hline 38 & Uncertain. & 15 & 470 \\
\hline 39 & Limestone, dark gray, fine grained.. & 5 & 475 \\
\hline 40 & Uncertain. . & 15 & 490 \\
\hline 41 & $\begin{array}{l}\text { Limestone, white.................. } \\
\text { Uncertain, }\end{array}$ & 5 & 495 \\
\hline 42 & Uncertain. & 15 & 510 \\
\hline 43 & 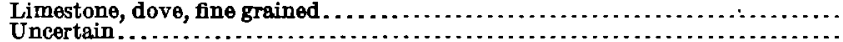 & 5 & 515 \\
\hline $\begin{array}{l}44 \\
45\end{array}$ & 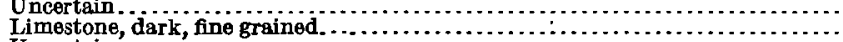 & $\begin{array}{r}10 \\
5\end{array}$ & $\begin{array}{l}530 \\
535\end{array}$ \\
\hline 46 & Uncertain.$\ldots \ldots \ldots \ldots \ldots \ldots \ldots \ldots \ldots \ldots \ldots \ldots \ldots \ldots$ & 15 & 550 \\
\hline 47 & Limestone, dark, fine grained............... & 5 & 555 \\
\hline 48 & Uncertain & 15 & 570 \\
\hline 49 & Limestone, dark, fine grained. "Little gas at 570 feet" & 5 & 575 \\
\hline 50 & 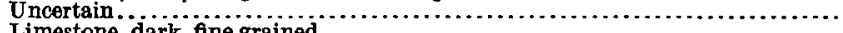 & 15 & 590 \\
\hline 51 & Limestone, dark, fine grained . . . . . . . . . . & 5 & 595 \\
\hline 52 & Uncertain & 15 & 610 \\
\hline 53 & Limestone, dark, fine grained. . . . . . . . . . & 5 & 615 \\
\hline 54 & Uncertain & 15 & 630 \\
\hline 55 & Limestone, dark, fine grained................ & 5 & 635 \\
\hline 56 & Uncertain & 15 & 650 \\
\hline 57 & Limestone, dark, fine grained. . ........................... & 5 & 655 \\
\hline 58 & Uncertain. & 15 & 670 \\
\hline $\begin{array}{l}59 \\
60\end{array}$ & $\begin{array}{l}\text { Llmestone, dark, fine grained } \\
\text { Uncertain }\end{array}$ & $\begin{array}{r}5 \\
15\end{array}$ & 690 \\
\hline 61 & 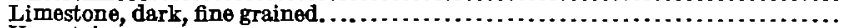 & 5 & 695 \\
\hline 62 & Uncertain......................... & 15 & \\
\hline 63 & 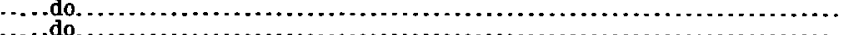 & $\mathbf{5}$ & 715 \\
\hline $\begin{array}{l}04 \\
65\end{array}$ & 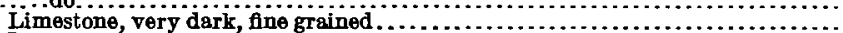 & $\begin{array}{r}15 \\
5\end{array}$ & 735 \\
\hline 66 & Uncertain & 15 & 75 \\
\hline 67 & 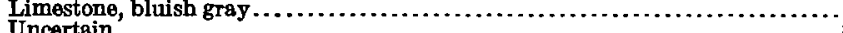 & 5 & 755 \\
\hline 68 & Limestone, bluish gray, drills to powder. "Showing oil from 520 to 755 feet"... & $\begin{array}{r}15 \\
5\end{array}$ & $\begin{array}{l}770 \\
775\end{array}$ \\
\hline & & & \\
\hline
\end{tabular}

Probably all Trenton (Catheys, Bigby, Hermitage), Lowville, and Stones River age. 



\section{INDEX.}

A. Page.

Acknowledgments for aid................. 15

Alcoken Oil Co., operations of ............. 21, 22

Allen County, farm lines and wells in the south-central part of, map showing.

geolopic sketch map of part of . .......... oil pools in, structure map of........... region around, geologic sketch $\mathrm{map}$ of.... structural position of.

Allen County Oll \& Gas Co., operations of... 21, 22

Altitudes in Allen County ................ 66-67

Analyses of oil ....................... 76-77

Analyses of salt water . .................. 80

Anticlines, descriptions of...............67-69

dry holes on ......................... 70

seareh for ............................. 90-91

untested for $0 i l . . . \ldots . . . . . . . . . . . . . . .8 ~ 89-90$

Ashley, G. H., cited ....................... 93

Asphaltic rock, occurrence of, M. H. Crump

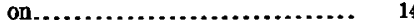

oil indicated by ...................... 88-89

Atlas Oil Co., operations of . .............. 21, 22

Austin farm, Barren County, wells on....... 114

B.

Banner Oil Co., operations of ............ 21,22

Barlow well No. 1, record of . ............... 94

Barnett Oil Co., operations of........... 21, 22

Barren County, geology of ............... 111-112 oil production in. . . ................ 112-114

Moritz Fischer on . . . . . . . . . . . 10-12

Barren River, course of ................... 15

Beaver Creek, oil pool on ............... 113-114

Beaver Creek (?) "sand," position of ....... 52 possible presence of. ................. 74-75

Beds, convergence of . . ................... 71

Berea grit, nature of..................... 51

Bibliography, annotated, of the region...... . 8-15

Big Trammel Creek, exposure of "Corniferous" limestone on, plate showing ..........................

Silurian exposure on

Blue Grass region, Ky., generalized section of the rocks of.

Boucher well No. 1, record of...............

Bowling Green, gas in wells near, pressure of.

Bowling Green, Ky., record of well at ...... 34-37

Boyd, J. W., wolls drilled by. ............ 21, 22

Boyds Creek, Barren County, wells on....... 113

Boyle limestone, see Limestone "Corniferous."

Bransford, Tenn., Ordovician rocks near....

Bilurian rocks near .................... 40-41

Breckenridge County, Ky., generalized section of the rocks of............. 27-29

Brine. See Water.

Bryley well No. 1, record of.

Burton well No. 1, record of c.

Page.

Carboniferous system, formations of......... 51-64

Carver wells Nos. 1 and 2, record of..........

Caves, formation of...................... 17 slumping of overlying strata into ....... 91

Chattanooga shale, nature of ............... 48-51 oil and gas in......................... 51

formation of ..................... 85-86

pseudo-anticlines, synclines, and faults

in, plate showing .............. 90

thickness of . ......................... $49-50$

use of, as key rock..................... 66

Chenault Oil \& Gas Co., operatior.s of...... 115-117

Cherry wells Nos, 2, 3, and 4, record of...... 95

Chester group, members and occurrence of... 64

Cincinnati, dome, Ordovician rocks of....... 33

Columbia quadrangle, Tenn., generalized sections of the rocks of.......... 26, 27

Convergence of beds, examples of........... 71

Cook, J. W., well No. 1, record of........... 37

"Corniferous" limestone, cavities in........ 73

exposures of, plates showing ............. 48

nature of ............................. 47-48

oil sands in .......................... 72-73

Cox well No, 1, record of................... 38

Crowe, M. B., farm, favorable locality on.... 91

Crowe wells Nos, 1-8, record of ............ 96-97

Crump, M. H., acknowledgments to........ 15 on oolite and asphaltic rock in Kentucky. 14

D.

Davie, W. J., on the farming lands of Kentucky ..........................

Development of oil fields, present and future of ............................ 93-94

Devonian system, formations of . . . ........ 43-51

Dinsmore, S. C., report by ................. 80-81

Dip, direction and amount of............. 64,65

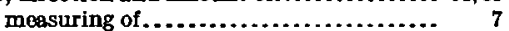

Distillation of oils, results of ............. 76-77

Drainage of Allen County ................... 15-17

Drilling, methods employed in............. 93-94

Dry rock, meaning of..................... $79-80$

F.

Farm lines and wells in the south-central part of Allen County, map showing...

Farming lands of Kentucky, W. J. Dsvie on.

Fleld work, record of

Fischer, Moritz, on the oil wells in Barren County, Ky ................ 10-12

Fishburn wells Nos. 1 and 2 , record of....... 97

Fisher wells Nos. 1-6, record of............ 97-98

Fohs, F. Julius, on oil and gas possibilities in Kentucky..................... 1

Fort Payne chert, fossils and oil in.......... 61 nature and occurrence of............... 60-61

Fossils, identifications of . . . . . . . . . . . . . 55-58 occurrence of ......... 40,41,47,48,52,59,61,62

Frost, J. W., wells Nos. 1-3, record of........ 98

Frost, V. A., wells Nos. 1-12, 15-26, record of. 98-102 
G.

Gas, early discovery of . . ................. $\quad 19$

occurrence of ......................... 77,88

surface indications of.................. 88-89

Geodes weathering out of Warsaw limestone, plate showing................, 60

Geography of the region.................. 15-18

Geology of Allen County . . ............... 23-75

Girty, G. H., on the age of the fossils from

Allen County.................... 53-55

Glasgow, o1l spring near ................. 112

Good Luck Oil Co., operations of..... 21, 22, 103-105

Great Southern Oil Co., operations of....... 21, 22

Grubb well No. 1, record of ............... 102

Guy wells Nos. 1 and 2, record of ........... 102

\section{H.}

Hartsville, Tenn., log of well near......... 121

Higgenbotham well No. 1, record of. ....... $\quad 115$

Hinton syncline, description of............ 69

Hinton wells Nos. 1, 2, 6-8, record of....... 102-103

structure at .................................

History of the oil industry................ 18-22

Hitchcock, C. H., on the occurrence of oil pools ........................... 8

Hoeing, J. B., acknowledgment to......... 15 cited . . ....................... 51,114-115 on the oil and gas sands of Kentucky.... 13

Holland, record of well west of.............. 38

Holson, A. M., farm, favorable locality on... 91

Hornbuckle well No. 2, record of.......... 103

Huntsman, E., well No. 1, record of........ 103

Huntsman \& Dixon, well drilled by ..... 21, 22,109

Huntsman, Harkless \& Hinton, well drilled by ........................ 21, 22, 110

Hurd, Robert, well, record of............. 116

\section{J.}

Joints, occurrence and effects of........... 71 Jones wells Nos. 1 and 2, record of.

\section{K.}

Keen, Martha, farm, favorable locality on.... 91 wells Nos. 1-15, record of .............. 103-105

Kenova Oil Co., operations of............. 21, 22

Kentucky, eastern, Ordovician rocks of...... 32 western, generalized section of the rocks in

Kentucky Geological Survey, map of Warren County issued by

Kern \& Co., operations of

Key rock, Chattanooga shale used as.........

Killebrew, J. B., on the occurrence of oil in Tennessee..

Knight, J. W., wells Nos. 1 and 2, record of..

L.

Leonard, W. C., on the geology of the Kentucky oil pools.

Limestone, bituminous, occurrence of....... "Corniferous." See "Corniferous" limestone.

Ordovician. See Limestone, "Trenton." St. Louis. See St. Louis limestone.

Ste. Genevieve. See Ste. Genevieve limestone.
Limestone, Silurian, oil in Page.

sink holes in.............. 17

plates showing.................... 62

"Trenton," depth to .................. 39

oil not found in................... 91-92

Warsaw. See Warsaw limestone.

Location of the region.................... $\quad 15$

Long Creek, course of..................... 15,17

exposure of "Corniferous" limestone on, plate showing................ 48

Long Creek Oil Co., operations of........... 21 record of well No. 1 of ................. $\quad 38$

Lyle well No. 1, record of................ 106

M.

McArthur Producing Co., operations of..... 21,22 Macon County, Tenn., limestones underlying 120

oil and gas wells in, M. J. Munn on...... 13

Mammoth Cave, location of .............. 17

Mantlo wells Nos. 1-3, record of............. 106-107

Map, geologic sketch, of a large part of Allen County........................

geologic sketch, of region around Allen County........................

of Warren County .................. 114

of south-central part of Allen County, showing farm lines and wells.....

structure, of main oil pools of Allen County

66

68

Marsh wells Nos. 1-3, record of.............. 107

Meredith well No. 1, record of ............... 107

Miller, Burd, wells Nos. 1-5, record of...... 107-108

Miller, Paul, well No. 1, record of........... 108

Miller, W. H., wells Nos. 1 and 2, record of... 108

Miller wells, structure at................. $\quad 70$

Mineral springs, waters of.................. 81

Mississippian series, determination of structure in . ...................... 90-91

lower strata of, fossils in.............. 53-58

nature of ........................ 51-53

Monroe County, Ky., limestone underlying 120

Moore well No. 1, record of................. 108

Mount Union, record of well near............ 38

Munn, M. J., on oil and gas wells in Macon and Sumner counties, Tenn..... 13-14

Myers well No. 1, record of . ............... 108

N.

New Providence shale, cross-bedding in. .... 58-59 nature of . . ............................ 58-59 oil in . . . . . . . . . .

North Petroleum oil feld, anticline under $67,69-70$ location of........................... 22

oil sands in, position of ................. 73 possibility of deeper oil sands in........ 92 possible extension of.................. 01 sections of wells in................... 42

o.

Ocala Oil Co., operations of........ 21,22,97,98,111 Oil, accumulation of . .................... 86-87 amber, description of ................. 77

oceurrence of ................... 113, 114 anglyses of ........................ 76-77 character of.......................... 75-77 collection of, from springs.............. 10 
Oil, occurrence of, in Kentucky, Moritz

Fischer on...................... 10-12

in Kentucky, S. F. Peckham on.... 10

origin of .......................... 84-86

possibilities of, F. Julius Fohs on ....... 14

production of, by months.............. 92-93

quantity of ............................. 83

recoverable percentage of .............. 83

surface indications of . . ................ $88-89$

See also Shale oil.

Oil and Gas Journal, cited ................. 21-22

Oil fields, distribution and extent of....... 22-23 possible extensions of.................. 91

Oil industry in Kentucky, Edward Orton on 12,

J. D. Weeks on .................. 12

Oil pools, relation of, to structure....... 69-70,88 relation of, to structure, C. H. Hitcheock

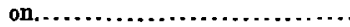

stratigraphy of, J. M. Safford on........

stratigraphy and structure of, W. C.

Leonard on.

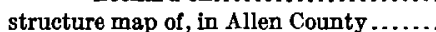

Oll sands, J. B. Hoeing on...................

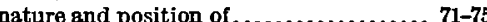

Oil springs, occurrence of ............... 12, 18-19

Oil wells, cost of drilling.................. 22

Oliphant, F. H., on the production of oil in Kentucky in 1897-99.

Oolite, oil in, M. H. Crump on...

Ordovician rocks of eastern Kentucky, classification of.

of the Cincinnati dome, classification of..

Ordovician system formations of .

Orton, Edward, cited

on the history of the oil industry in Kentucky.................. 12, 18-20

Oskamp well, Barren County, record of...... 113

\section{P.}

"Pay sands." See Oil sands.

Peckbam, S. F., on the occurrence of oil in Kentucky

Pennsylvanian series, occurrence of, northwest of Warren County..........

Petroleum. See Oil.

Petroleum, $\mathbf{K y}$., original structural features near, plate showing.

Petroleum anticline, description of .

Petroleum Oil \& Gas Co., operations of .... $22,95,107,11$

Porosity, development of, in limestome of oil sands........................ 82-83 of rocks, relation of, to oil pools......... 89

Porter, Uriah, farm, oil wells on ........... 19, 20

Position, structural, of Allen County. ....... 23-25

Production of oil from 1897-99, F. H. Oliphant on..............................

Prospecting, suggestions for................ 89-02

\section{Q.}

Quaternary system, deposits of.

R.

Reaves, W. Hart, farm, log of well on....... 121 Reoves, Denton, farm, favorable locality on 91 wells Nos. 1-3, record of .............. 108-109

Relief of Allon County
Page.

Republic Oil Co., operations of ....... 21, 22, 95, 97

Reynolds well No. 1, record of............. 109

Rhoda, Edmonson County, Ky., record of well near.................... 37

Richards wells Nos. 1-3, record of.......... 109

Richmond group, occurrence of............. $\quad 40$

Roads of Allen County .................. 17-18

Rocks, imperviousness of................. $\quad 82$

Rodemer, oil pool east of . . .................. 20-21

Rodemer oil field, anticline under. . . . . 67, 69-70 location of .......................... 22 oil sand of .......................... 72 possibility of deeper oil sands under..... $\quad 92$ possible extension of................. 91 sections of wells in .................. 44,45 Rough Greek anticline, description of ........ $\quad 68$ Rush well No. 1, record of .............. 108

\section{s.}

Safford, J. M., on the stratigraphic position of the oil reservoirs. ...............

St. Louis limestone, exposure of, with two pseudo-anticlines, plate showing.

local unconformity in, plate showing... $\quad 60$ nature and occurrence of................ 61-62 sink hole in, plates showing.............. 62

St. Peter sandstone, depth to .............. $\quad 39$

Ste. Genevieve limestone, nature of......... 62,63 occurence of, in Warren and adjoining counties..................... 62

sink hole in, plate showing............ 62

Sands, deep-lying......................... 25-26

"pay," depth to....................... 43

nature and position of.............. 71-75

Saunders, G. M., wells Nos. 1 and 2, record of............................ 119-120

Scottsville oil field, location of .............. 22

Shale, Chattanooga. See Chattanooga shale.

Shale oil, nature and extraction of.......... 83

Shooting of wells, value of................ 91,94

Silurian system, rocks of................. $40-43$

Simpson County, Ky., geology of.......... 118 well drilling in........................ 118

Sink holes, occurrence of.................. 17

plates showing......................... 62

Snake Creek, apearance of an anticline on... 68

South Petroleum oil pool, location of....... 22

South Tunnel, Tenn., records of wells at.. 112-120

Southern Oil Co., operations of. ..... 21, 22, 108-109

Spergen (?) limestone, possible cocurence of.. $\quad 61$

Stamp well No. 1, record of................ . 110

Stratigraphy of the region . ................ 25-64

Strike, direction of........................ 65

Structural features, unimportant, developed through erosion and slumping, plates showing.................. 90

unimportant, near Petroleum, Ky., plates showing................. 58

Structure, favorable, for prospecting........ $\quad 89$ favorsble, known areas of.............. 89-90 search for........................ 90-91 of the region.......................... 64-71

Structure contours, base and accuracy of..... 66-67 Sumner County, Tenn., geology of.......... 119 oil and gas wells in, M. J. Munn on...... 13-14 well drilling in...................... 119-120 Synclines, descriptions of................. 60 
T.

Tabos well No. 1, record of............... 110

Tennessee, oil in, J. B. Killebrew on......... 10

Towns of Allen County.................... 17-18

Trammel anticline, description of............ 68

"Trenton" limestone. See Limestone, "Trenton."

Tucker wells Nos. 1-5, record of............ 110

Turlock basin, description of. .............. 69

Turlock oil pool, location of.................. 23

U.

Ulrich, E. O., cited...............4 41,48,50-51

W.

Walker, $\Lambda$. S., land, drilling for oil on....... $\quad 20$ oil spring on.......................... 19

Walker well No. 1, record of............... 111

Warren County, Ky., generalized section of rocks in....................... 63

geologic map of...................... 114

geology of........................ 114-115

oil development in................... 115-117

publication of map of.

12

Warsaw limestone, geodes weathering out of, plate showing..

nature and occurrence of.

61

Water, flow of, conditions requisite for...... 78-80

flow of, under pressure of gas.
Page.

Water, occurrence of, in oil and gas fields. 77-82,88 replacement of oil by .................. 94 salinity of .......................... 80-81 salt, origin of ....................... 81-82 pickling effect of .................. 82

Watkins well No. 1, record of.............. 111

Waverly group, correlation with........... 51-62

Wayne County, Ky., rocks below the Devonian shale in................. 32

Weeks, J. D., on early oil wells in Kentucky.. $\quad 12$

Wells, capacity of..................... 84 records of........................ 34-38,94-111 sections of............................. 42-46 in the south-central part of Allen County, map showing................... $\quad 66$

White Plains Oil \& Gas Co., acknowledgment to ....................... 15 operations of......................... 21,22 , 94-97, 98-102, 103, 106, 108-111

Wildwood oil fleld, location of............. 22 pasition of oil sands under............. 73 sections of wells in..................... 43 structure beneath.................... 70

Willey well No. 1, record of.............. 116,117 Williams, J. L., well No. 1, gas flame from.. 77 record of........................... 111 $\mathbf{Y}$.

Younglove Bros., oil produced by .

\section{ADDITIONAL COPIES}

OI THS PUBLICATION MAY BE PROCURED FROM

THE SUPERDNTENDENT OF DOCUMENTE

GOVERNMENT PRINTING OFFICE

WASHINGTON, D. C.

$\Delta T$

20 CENTS PER COPY 